Ireneusz Krzemiński

\title{
Solidarity:
}

The Unfulfilled Project of Polish Democracy

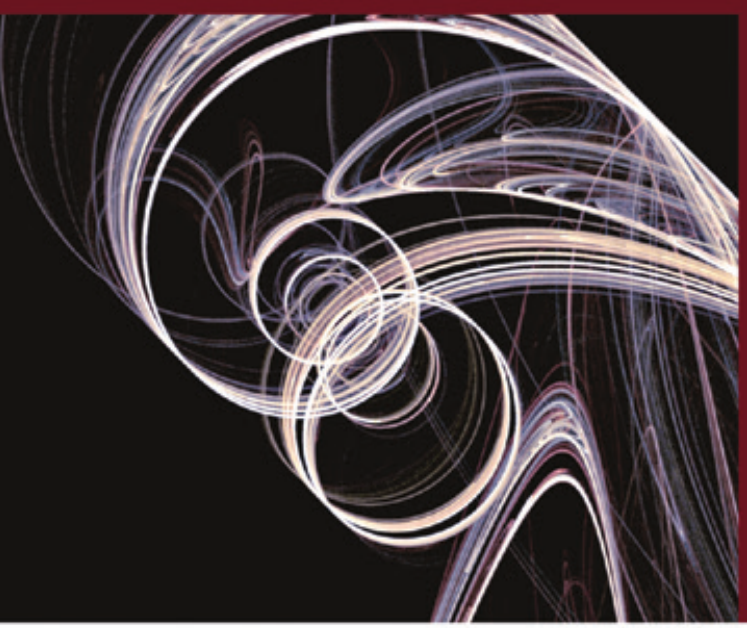


Ireneusz Krzemiński

\section{Solidarity: The Unfulfilled Project of Polish Democracy}

This book is a collection of essays which span three decades, capping research into the Polish Solidarity movement and its impact on social change. The major one reports on the author's 1981 study on the formation of the Solidarity movement and trade union, one of two research projects on Solidarity carried out at the time. The idea of debating (deliberative) democracy fostered by Solidarity proved an unfulfilled utopia. It was abandoned by the new political elite and by Poles, who used freedom to develop individual, ambitious and aggressive career paths in order to attain West-European living standards. While Polish religiosity and the Catholic Church, led by Pope John Paul II, vitally promoted peaceable resistance to communism, now the Church has morphed into an anti-democratic political and cultural actor.

\section{The Author}

Ireneusz Krzemiński is Professor of Sociology at the Institute of Sociology, University of Warsaw. His research focuses on anti-Semitism, national stereotypes, Solidarity and new social movements. He taught at universities in Poland and abroad (Rochester University, USA; Hebrew University, Jerusalem). He is engaged in public and political life as a commentator and publicist. 
Solidarity: The Unfulfilled Project of Polish Democracy 


\title{
STUDIES IN POLITICAL TRANSITION
}

Edited by Klaus Bachmann

\author{
Advisory Board: \\ Aleksandar Fatic, University of Belgrade (Serbia) \\ Tom Junes, Human and Social Studies Foundation, Sofia (Bulgaria) \\ and Imre Kertész Kolleg Jena (Germany) \\ Gerhard Kemp, Stellenbosch University (South Africa) \\ Irena Ristić, Institute of Social Sciences, Belgrade (Serbia) \\ Lavinia Stan, Nova Scotia University (Canada)
}

\section{VOLUME 13}

\section{(6)


Ireneusz Krzemiński

\section{Solidarity: The Unfulfilled Project of Polish Democracy}

Translated by Patrycja Poniatowska

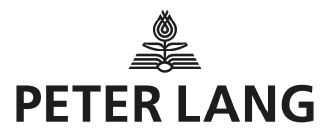




\title{
Bibliographic Information published by the Deutsche Nationalbibliothek
}

The Deutsche Nationalbibliothek lists this publication in the Deutsche Nationalbibliografie; detailed bibliographic data is available in the internet at http://dnb.d-nb.de.

\section{Library of Congress Cataloging-in-Publication Data}

A CIP catalog record for this book has been applied for at the Library of Congress.

The Publication is funded by Ministry of Science and Higher Education of the Republic of Poland as a part of the National Programme for the Development of the Humanities. This publication reflects the views only of the authors, and the Ministry cannot be held responsible for any use which may be made of the information contained therein.

\author{
E national programme \\ FOR THE DEVELOPMENT OF HUMANITIES \\ Cover illustration: Courtesy of Benjamin Ben Chaim \\ ISSN 2191-3307 \\ ISBN 978-3-631-67270-9 (Print) \\ E-ISBN 978-3-653-06851-1 (E-PDF) \\ E-ISBN 978-3-631-70990-0 (EPUB) \\ E-ISBN 978-3-631-70991-7 (MOBI) \\ DOI 10.3726/b16065
}

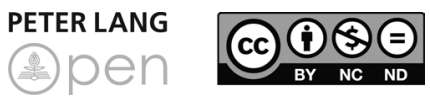

Open Access: This work is licensed under a Creative Commons Attribution Non Commercial No Derivatives 4.0 unported license. To view a copy of this license, visit https://creativecommons.org/licenses/by-nc-nd/4.0/

(C) Ireneusz Krzemiński, 2019

Peter Lang - Berlin · Bern · Bruxelles · New York .

Oxford $\cdot$ Warszawa $\cdot$ Wien

This publication has been peer reviewed.

www.peterlang.com 


\section{Contents}

Solidarity: Years Later. A New Introduction to the English

Edition

The Forgotten Past

\section{Part One}

The Way It Was: Solidarity and Empirical Sociology

"Hot Sociology": Research Assumptions and Procedures ............. 33

Workplace-Based Communities: The Selection Criteria ............................... 33

The Multi-Perspective Research Design ....................................................... 34

Competent Informants and the Main Research Questions ........................... 35

Research Methods: The Epistemological Underpinnings ............................. 36

Basic Theoretical Assumptions: Symbols and Actions .................................... 37

Research Method: The Insider's View ......................................................... 38

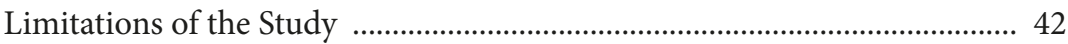

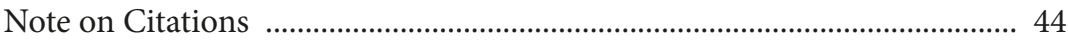

\section{The Rise of the Independent Self-Governing Trade Union}

"Solidarity" ............................................................................................... 45

Celebrating the Agreement ........................................................................... 45

The Explosion of Self-Organising ................................................................... 47

The Formation of the Social Movement .......................................................... 52

The Summer of Revolt and Protest ............................................................ 52

Warsaw on Strike: The Summer of 1980 ................................................... 54

The Factors behind Collective Protests .................................................... 65 
The Discontented-and-Defiant ................................................................... 66

We: The Circles of Community ................................................................... 68

The Common Definition of the Situation ..................................................... 84

Intellectuals and Big Industry Workers: Generational Groups ............ 86

The KOR and the Democratic Opposition ................................................ 87

The Pope's Visit and the Catholic Church ................................................. 92

Implementing the Ideal: Building the Independent Trade Union .............. 95

Autumn 1980: Definitions of the Social Situation ........................................ 95

It Can't Go on Like This Anymore .......................................................... 95

The Public Must Understand .................................................................... 102

"Somebody Must Be in Charge of the Whole Thing" ............................ 113

"Three Souls" of the Directors ..................................................................... 117

Establishing Independent Trade Union Units ............................................. 124

Turning Points ......................................................................................... 124

Models of Founding Independent Trade Union Units ........................... 126

The Organisers .......................................................................................... 129

Impeding the Formation of Independent Trade Union Units ............... 130

Practical Measures .............................................................................. 131

Symbolic Measures ......................................................................... 132

Solidarity's Organisational Dilemmas ........................................................ 133

Lacking Models ................................................................................ 133

Lacking Communication ............................................................... 135

The Pressure of Social Expectations ................................................ 136

\section{Part Two}

\section{What Was Solidarity? Interpretations of the Solidarity Trade- Unionist Movement: Introduction to Part Two}

\section{The Rooted World}

Civil Society: How the Idea Developed ........................................................ 142

The Definition of the Social Situation and the Need for Roots .................. 145 
The Cultural and Spiritual Relevance of Democracy .................................... 147

Religion and the Idea of Democracy .............................................................. 148

Rootedness in Values and the Diversification of Social Thinking .............. 150

Sociology and Social Processes ........................................................................ 154

The Role of Generational Groups in the Social Movement ......................... 156

Sociology, Society and Roots ..................................................................... 160

\section{Poland after Solidarity: Social Consciousness and People's} Attitudes ……............................................................................................. 163

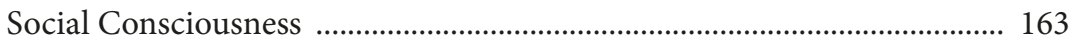

Ubiquitous Politics ........................................................................................... 165

Stage One: Moral Victory and Underground Society ……………………... 169

The Turning Point: Society Disintegrates as “They” Prevail ........................ 176

The Church as a Substitute of Society: The Devil in History ....................... 179

The Negative Definition of the Situation: "People Don't Matter One Bit, Only Force Does" ...................................................................................... 184

Variant One: Conformist Harmony …………………………………...... 187

Variant Two: A Manichean Drama with Messianic Elements ................ 188

Variant Three: Egoistic Escapism ................................................................ 189

Variant Four: Desperate Dissent ............................................................ 190

The Polish Modes of "Escape from Freedom" ................................................ 191

Variant One: Conformist Harmony ......................................................... 192

Variant Two: A Drama of Mortality and Eschatology ............................. 192

Variant Three: Egotist Escapism ................................................................ 193

Variant Four: Desperate Dissent ................................................................. 194

"Internalisation of Violence" and Privatisation of the World ...................... 195

The "Enactment" of Declared Values ........................................................... 197

The Right to "Make Money" ............................................................................ 198

The Latent Negative Worldview behind Positive Changes .......................... 201 


\section{Challenges to and Risks in Poland's Democratic Transition:} A Social Psychology Perspective ........................................................... 203

A Lyrical Model of Capitalism .................................................................... 203

The Democratic Personality .............................................................................. 205

Polish Negativity ............................................................................................... 207

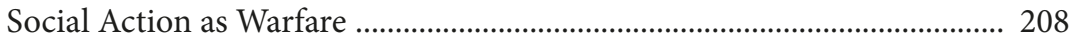

Bad Individualism and Bad Identity ................................................................ 209

The Manly Attitude ......................................................................................... 210

Babstwo: A Short Theory ……………………………................................ 210

Resentment, or Poles Are Owed It ................................................................ 212

Authoritarianism and Lost Subjectivity ........................................................ 213

Money, Money, Money... ................................................................................. 213

Forgotten Labour and Devalued Education ................................................ 214

Evil Legacy: An Evil Capitalist ....................................................................... 214

The Future and Liberalism: Anxieties and Concerns ................................... 215

\section{Part Three}

\section{After Solidarity: Introduction to Part Three}

\section{Solidarity: The Organisation of Polish Hopes ……………………... 223}

The Transformation Process: Preparations for Joint Action ........................ 224

The Organisation of Protest, the Birth of Civic Consciousness and Reformist Demands ................................................................................. 226

Community: The Image of the Individual and the Civil Image of Society and the Nation

The Wisdom of the Majority and the New Citizen Mentality: A Short Critical Digression 
The Independent Trade Union as a Laboratory of the Democratic State 235

Conclusion: A Handful of Still Pertinent Insights 238

Revolution, Solidarity and Words ........................................................ 243

The Language of Solidarity ......................................................................... 243

In the Grip of Pernicious Politics ........................................................ 249

The Social Problem Turned Political Problem ................................................ 249

Solidarity and an Idealising Vision of Politics ............................................. 250

The People's Republic of Poland, Martial Law and a Cynical Vision of Politics

The Transition and the Original Sins of the Reborn Republic ................... 258

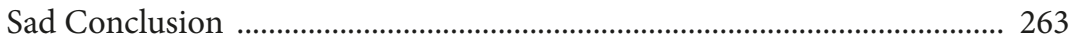

The Republic of Hateful Enviers .......................................................... 267

Changes in the Language of Public Debate ..................................................... 267

Political Divisions and Social Divisions ....................................................... 271

The Catholic-National Socio-Political Unity ……………………………...... 275

The Mentality of Religious Repression ........................................................... 277

Hateful Envy and Anti-Democratic Authoritarianism ............................... 279

Solidarity: Experience and Memory. Narratives of the Activists of the Gdansk Region .......................................................... 285

Small Town vs. Big City ................................................................................. 285

Motives and Goals of Social Action: The Solidarity Movement as the Basis of the Trade Union 290

The Relevance of the Earlier Experiences and Protests in the Coastal Region 
The Crowd, Civil Society and the National Church: The Polish Dispute over the National Symbols and Identity in 2010 ........................................................................................ 303

Spontaneous or Pre-Programmed? ............................................................ 306

The Media, the State and the Church ……………………............................... 309

The Church, Polish Catholicism and Civil Religion ...................................... 313

Mourning as a Significant Social Fact ………................................. 317

Peace as a Method of Social Action: The Path of Polish

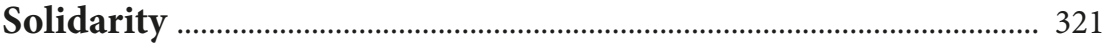

Conclusion: Solidarity and Bad Memory …………………………..... 335

Bibliographic Note …………………………………………………. 345

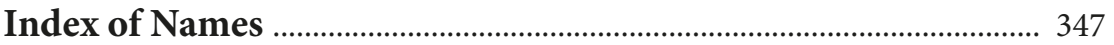




\section{Solidarity: Years Later. A New Introduction to the English Edition}

This volume may well seem a collection of outdated scribblings. It ponders social developments that took place a very long time ago. It recounts the first (and, in general, scarce) studies on the social movement of Solidarity in Poland in 1980-1981. It seems so ancient that we would be justified to scratch our heads, wondering whether it even makes sense to recall those days. The idea to rehearse reflections on Solidarity from several years ago may indeed raise more than one brow. After all, democracy that Solidarity trade-unionists made their goal has long been achieved. But now, in 2017, this goal seems at jeopardy in Poland and elsewhere in Europe. The aspiration to live in united Europe, which millions of Poles had cherished for years, came true quite a while ago. But united Europe looks nowhere near stable even as we speak of it now.

I will answer these doubts with a boldness typical of authors: the same wave of social processes that is surging across Europe and the globe these days, apparently pitting nationalist and authoritarian discourses against the ideas of liberal democracy, makes this book a worthwhile reading. For this volume was written by a social scholar, not by a historian. As such, it helps understand processes which so strongly promoted democracy and social cooperation back then, in the circumstances hardly favourable to individual and social freedom. After all, the demolition of the Solidarity movement by the military government of the communist Party ${ }^{1}$ precipitated the total societal delegitimisation of the regime. And a few (long and hard to Poles) years later, it put an end not only to the system constructed in Poland after the Second World War, but also to the entire Soviet system. A scrutiny of social, political and psychological mechanisms at work in those days and an insight into people's unfulfilled dreams can give us valuable knowledge to rely on in our perturbed, astonishing times.

This volume contains my research not only on the formation and rise of a vast social movement, but also on its consequences, peculiar "obliviousness" and failure to fulfil people's aspirations. The chapters compiled in this book come from various periods, whose exact dating is far less relevant than distinctive

1 The communist Party refers to the Polish United Workers' Party (Polish: Polska Zjednoczona Partia Robotnicza), which was popularly referred to as the Party throughout the communist period. (translator's note) 
social mobilisations and experiences. These periods include the rise of the Solidarity movement and Trade Union, the dark years of severe communist dictatorship in the 1980s and, finally, the time of liberation and the formation of a new society and a new state in the 1990s, followed by the years when democracy matured. What on paper seems barely more than a dozen years was felt by people as several different epochs.

The memory of Solidarity in Polish society is a paradoxical thing. The unexpected triumph of Solidarity's fundamental aspiration - social and political liberation - has not resulted either in reviving the movement itself nor, perhaps even more poignantly, in reinvigorating the civic values, which had been so pronounced in original Solidarity's liberating and reformatory movement. People's civic engagement and the notion of politics as thinking together about how to organise a good social life have proved but fleeting values. And expectations have outgrown the actual possibilities of the emergent new socio-political order since the very beginning.

Both the general public and the Solidarity-formed social elite (or elites) expected a renewed mass engagement with the Independent Self-Governing Trade Union "Solidarity," emulating its legal period, and a rise of a huge, peaceable civil movement. Back in the late 1970s and 1980s, even when the trade union was officially disbanded, people were actively involved in pro-democratic, socio-political work across various levels of social life. Yet, when freedom finally came, most Poles turned out surprisingly reluctant to engage in social and civil commitments. The available Polish literature does not offer any tolerably coherent or homogeneous explanation of this development. What happened to what seemed Solidarity's fundamental notion that people's care for their own and their loved ones' lives also entailed the right and the obligation to commit to others and to the common good, which was a major factor in personal success and failure? What happened to the belief that, while fully enjoying individual human and civil rights, we must not fail to feel part of society, of a civic community, whose wellbeing was everybody's indelible responsibility? What happened to the movement assembling dedicated and infinitely resourceful citizens after their common enemy had disappeared and the fruit of the joint action could be freely savoured? And, finally, what happened to the spirit of tolerance and mutual kindness, to the deep-running belief that everybody was equally entitled to have a say in matters they found important, disturbing and/or pertinent? That everybody's voice should be listened to without hostility towards or exclusion of those thinking differently than the majority? Since answers to such basic questions are very hard to find, it does not come as a surprise that many scholars now tend to agree that the Solidarity movement was a unique "festival" 
and "social carnival": an exceptional development that cannot be expected to continue or to produce a stable framework applicable in the "regular" democratic social life.

This view, however, cannot be fully endorsed, for the Solidarity movement was certainly a highly democratic enterprise within the developing independent trade unions. The fundamental thesis of this book is expressed in its title; I argue that the Solidarity social movement and the trade union, which operated legally in 1980-1981 and clandestinely afterwards, invented and attempted to practise a distinctive and original model of democracy. Therefore, Solidarity can serve today as a model project of a democratic order at the level of societies, states, institutions and/or big organisations.

In hindsight, we can see that it was a utopian model, and, in fact, it has been described as such by various researchers. This approach is exemplified in Marcin Frybes and Patrick Michel's Apres le communisme. Mythes et legendes de la Pologne contemporaine published first in France in $1996 .{ }^{2}$ There was a time when I disputed the authors' theses, but now I believe that the utopian element in Solidarity people's thinking about the organisation of the future social world must not be overlooked. At the same time, this particular utopia is still on people's minds and hearts, not only in Poland.

The Polish-Danish philosopher Bronisław Świderski offered a surprising interpretation of the significance of the Solidarity movement in his 1996 book Gdansk $i$ Ateny (Gdansk and Athens). ${ }^{3}$ Swiderski's main insight is that the ideals promoted by the Solidarity movement resembled, in fact, the Athenian direct democracy. Even though I disagree with Świderski's many views, I could subscribe to this fundamental thesis; it still rings true and provides stimulating food for thought.

Swiderski's central tenet is close to my basic thesis about the social movement of Solidarity: the movement was an attempt to turn "ordinary" Poles into citizens and make dedication to the common good part of people's focus on everyday, individual prosperity. People's participation in decision-making on matters of interest to entire society, matters which directly or indirectly, immediately or eventually affected everybody, was the most profound ideological - and I would

2 Marcin Frybes and Patrick Michel, Après le communisme. Mythes et légendes de la Pologne contemporaine (Paris: Bayard Edition, 1996). For the Polish edition, see Marcin Frybes i Patrick Michel, Po komunizmie: o mitach w Polsce współczesnej, trans. Jan Maria Kłoczowski (Warszawa: Krupski i S-ka, 1999).

3 Bronisław Świderski, Gdańsk i Ateny: o demokracji bezpośredniej $w$ Polsce (Warszawa: IFiS PAN, 1996). 
even say spiritual - aspect that swayed people to embrace common action. This was the factor that I believe helped lay the foundation for the Solidarity mentality, combined with the "citizenation" of the nation. Being part of a community, which entailed the right and even the imperative to participate in the debate on social action - that is, in politics - was founded on another inalienable component of the Solidarity identity: on personal dignity, individual dignity, which was encapsulated in the popular notion of "subjectivity" (podmiotowość).

"Subjectivity" made a staggering career in 1980 and 1981. It became common currency among the educated and the uneducated alike. It also served as a powerful ideological weapon, as it emphasised that a system could not possibly be good unless it guaranteed basic rights and dignity to the citizens. To this core set of values, "subjectivity" - that is, the capacity to hold one's fate and that of one's loved ones in one's own hands - added each citizen's commitment to the common good and communal life. Consequently, a system could not possibly be good if it limited individuals' right of self-constitution and did not allow them to discuss and assess the policies of the state, of the party-state to use the sociologist Jan Strzelecki's very apt coinage. The right to subjectivity was handily weaponised against the communist order.

This was intimately associated with the "citizenation" of the nation. After all, the citizens who united around civil liberties and rights made up a "nation." And, equally importantly, while being a nation they were part of Europe, part of the West as opposed to the East. The opposition of Poland/West and the Soviet, or Russian, East was one of the major factors organising the way people thought at the time. The "not like in the East" adage represented the inclusion of respect for freedom into the ensemble of national values. Politically independent society and statehood went hand in hand with the citizens' personal freedom and individual rights. National, state and individual independence formed an inseparable ideological "cluster." Citizenation and subjectivity entailed readiness to act, and social pro-activeness involved commitment to communal matters as capping a good, adult life, a fully moral life even. This ideal is still vibrant in the social memory of the "first" Solidarity activists, as suggested by the studies on the memory of Solidarity which have been carried out by the Centre for Research on Solidarity and Social Movements in collaboration with the Gdansk-based European Solidarity Centre since 2010. ${ }^{4}$

4 In 2010, I launched the first research project entitled Solidarność - doświadczenie i pamięć (Solidarity: Experience and Memory) in collaboration with Warsaw's Centre for Public Opinion Research, funded by the European Solidarity Centre. The Polish publication with the study's findings was released in the same year. As the project went on 
What happened to the civil society galvanised by Solidarity which was robust even in the dark 1980s is a crucial question that haunts Polish social and political scholars. When, at the long last, Poland thankfully got its chance to build an independent and democratic state, its citizens' engagement in public life plummeted. For years, the voter turnover, both in the general and in the local elections, has been consistently low. Even 1989, the year of the first semi-democratic election, which incisively changed the political system, did not see any eruption of participation. Just over $60 \%$ of the citizens went to the booths. And to think that the election set off "the Autumn of Nations" in Eastern Europe and, consequently, hastened the dismantling of the communist system in the USSR as well! For comparison, in Bulgaria, where social resistance movements had been frail to the point of non-existence, nearly $90 \%$ of the citizens voted in the first free election.

Secondly, the formation of Tadeusz Mazowiecki's first non-communist cabinet was not followed by any spectacular increase in social activity. Admittedly, as shown by Polish-American researchers Jan Kubik i Grzegorz Ekiert, ${ }^{5}$ in the first years of the transition Poles organised first and foremost in protests. The protests expressed various demands and served as a form of public debate, or rather they filled in gaps in the existing public debate, with streets of the capital city serving as a huge public discussion forum. Citizens took to the streets to debate in an endless string of marches and rallies. Even if we agree with Ekiert and Kubik that this served as a platform for social debate, where views could be shared and confronted with each other, the debate would likely have been more effective, to-the-point and nuanced if as many people had indeed been involved in a full-fledged, candid, both unfettered and more orderly discussion. This actually was the case with the "first" Solidarity.

Ii is for good reason that I refer to it as the "first" Solidarity. The movement and trade union activists we interviewed in our research agreed that it was an

in subsequent iterations, another book appeared in 2016 (Solidarność - doświadczenie $i$ pamięć [Solidarity: Experience and Memory] and Solidarność - doświadczenia i pamięć po raz drugi [Solidarity: Experience and Memory Revisited]). My research team from the Centre for Research on Solidarity and Social Movements at the Sociology Department, University of Warsaw, included Wojciech Ogrodnik, Marcin Jóźko, Krzysztof Martyniak and Dominik Wasilewski. The study was carried out across Poland, specifically in Białystok, Gorzów Wielkopolski, Zielona Góra, Żyrardów, Łódź, Płock, Radom, Rzeszów, Legnica-Lubin-Polkowice and Bielsko-Białą.

5 See Grzegorz Ekiert and Jan Kubik, Rebellious Civil Society: Popular Protest and Democratic Consolidation in Poland, 1989-1993 (Ann Arbor: University of Michigan Press, 2001), p. 278. 
apt choice, and that the Independent Self-Governing Trade Union "Solidarity" reactivated in 1989 was not the same as the union destroyed by martial law. The new Solidarity neither regained its powerful membership nor revived its never fully expressed ideological potential. The union robustly engaged with abrupt and often costly political and economic changes, and it soon became a political actor of quite firm ideological leanings. Consequently, the trade union started to lose its membership base rapidly and took a definite position as a player on the political arena. In 2010 and 2011, even the activists of the current union hailing from the first Solidarity were highly critical of the union's "excessive politicisation," despite their overall allegiance to the political party to which the union had become "a political annex," so to speak.

To finish with, let me stress that this volume is not a simple re-edition. Inspired by the Head of the European Solidarity Centre, I added a third part to it. It includes texts that revisit the earlier discussed factors in and the values of the Solidarity experience in order to understand what happened to the civil society that issued forth the Solidarity movement and then was shaped by this movement in turn. I do not know whether I can answer this question comprehensively, but I hope that my insights will shed some light on the phenomenon of Solidarity, which is transforming into a big socio-political myth, as French sociologists pithily put it.

In Conclusion, I will look into the questions asked in this Introduction through a social scientific lens and see what happened with the Solidarity experience, whether its legacy is still vivid in the memory of its participants (as suggested by field research) and whether it still harbours a social, political or, simply, civic potential. My answers, tentative though they may - or perhaps must - be, will hopefully add up to a pertinent account of our knowledge of the social and trade-unionist movement of Solidarity and our perception of Poles' grand collective work of the $20^{\text {th }}$ century. 


\section{The Forgotten Past}

In the early 1980s, the word "solidarity" captured people's imaginations and became a common catchphrase. And that was the case not only - one could say particularly not - in Poland. The word was revived, taking a new lease of life and a new relevance as a social and political tag. Before 1980, "solidarity" featured in political discourse in two contexts which gave it a slightly ambiguous ring. In one of them, when used by serious political scientists, it sounded ironic and corresponded to "social solidarism." Back then, social solidarism was (and as a matter of fact still is) viewed as an unfeasible socio-political concept that posited bonding and collaboration between social groups - classes - despite their conflicting positions.

In broad lines, political scientists are ironic about solidarism, as its advocates have generally failed to appreciate either the relevance of conflicts spawned by divergent interests or the power of mutual dislike, envy and resentment between those on "top" and those at the "bottom" of the social hierarchy. Solidarists firmly believe that the upper echelons of society are ready to take account of the needs and demands of the lower strata, while the latter are perfectly capable of tempering their claims for the sake of common good; serious researchers insist, however, that this belief is belied by historical experience and the lived social reality. They also sneer ironically at solidarists' belief that the upper social classes can become a genuine authority for their social inferiors, which will breed harmony and understanding between the "top" and the "bottom" rungs of the social ladder.

Anyway, conflict lines can run not only between classes but also between other large groups of citizens who hold different positions and embrace entirely different political arrangements or entirely different notions of national tradition and its role in the state. In such cases, solidarists will also presuppose that agreement is possible, especially if facilitated by commonly recognised authority figures. ${ }^{6}$

In the other context, the word "solidarity" was also given a class-inflected meaning, albeit one opposed to the solidarist vision. Solidarity was supposed to be intrinsic to the working class, whose members had come to be aware that they shared the same fate. On this model, the working class was a symbol of all the oppressed, the humiliated and the exploited. Consequently, proletarian

6 In Poland, Marcin Król tended to be suspicious of solidarism in Solidarity. 
solidarity was attributed to all the oppressed, the humiliated and the exploited. Hence, Stanisław Skorupka's 1968 Słownik frazeologiczny języka polskiego (A Phraseological Dictionary of the Polish Language) lists multiple examples of such usage of "solidarity" and "solidary." The dictionary describes solidarity by modifiers such as "internationalist," "of the proletariat," "of the peace bloc" and, finally, "of the fighting proletariat." By definition, solidarity between the proletariat and capitalists was out of the question, but solidarity of all workers, regardless of their national, occupational or financial differences, was indeed necessary as only such solidarity could help workers, in fact humans as such, shake off their fetters. In this sense, solidarity was contrasted with solidarism, which could hardly be anything else than an invention of the ruling and monied classes designed to beguile the exploited. Therefore, solidarity only concerned the working class and its allies who grasped the proletariat's historical mission. Only the humiliated and the exploited could stand in disinterested solidarity with each other.

The Independent Self-Governing Trade Union "Solidarity" was founded as an organisation mainly because people were stirred by another meaning of "solidarity." Even in the Skorupka Dictionary, "solidarity" primarily designates solidary involvement in common action: "acting in unison - one for all and all for one." And the "solidarity" entry in the Słownik jezzyka polskiego (Polish Language Dictionary) says that "being solidary" refers to unity in action and aspirations as well as to unanimity or consensus, ${ }^{8}$ adding that "to stand in solidarity" also denotes "to feel co-responsible." Given this, we can argue that Solidarity as a trade union and a social movement that founded it has contributed to crafting a new social and political scientific term. One of my major goals in this book it to interpret the new theoretical meaning that the common noun "solidarity" has accrued. ${ }^{10}$

7 Stanisław Skorupka, Słownik frazeologiczny języka polskiego (Warszawa: Wiedza Powszechna, 1968), p. 163.

8 Słownik języka polskiego, ed. Witold Doroszewski, vol. 8 (Warszawa: PWN, 1966), p. 490.

9 Ibid., p. 491.

10 The meanings invested in the word "solidarity" were interpreted by Reverend Józef Tischner in his Etyka solidarności (Ethics of Solidarity) (Kraków: Znak, 1981). Many of his ideas dovetail with mine, but I believe that insights presented by Rev. Tischner are impacted more by his philosophy than by a sociological analysis of the meanings of solidarity in Solidarity. 
Firstly, "solidarity" as a catchword and a name targeted the self-appointed group that had claimed for decades to express the concerns and ambitions of the proletariat and of all the oppressed, the persecuted and the humiliated. But, at that moment, it had long been clear to everyone that the ideology which allegedly stood up for workers had become a tool of tyrannical control over individuals and all expressions of human life.

Secondly, "solidarity" very specifically called for bonding between the groups "on top" and "at the bottom." This jarred with official ideology, in which the "top" positions were to be taken by the working class. In fact, a number of ideological and, even, administrative manoeuvres were implemented to adjust life to the ideology and elevate workers over the intelligentsia, or at least some working-class groups over your "average intellectual." The manoeuvres hardly proved effective.

Such measures were anyway doomed to failure given that ordinary people common workers - even when pushing their own claims were inclined to accept that, say, doctors deserved to earn more, for they had studied for years and their job was very important. Solidarity was founded on such common-sensical thinking; common sense, in fact, offered a new quality, as it entailed thinking about society as a community of varied groups and individuals who, though differing in their social situations and roles, had common and equal rights, while taking upper or lower positions should depend first of all on people's individual efforts. If the social reality was different - and it was very much different, indeed - so much worse for the reality! For that reality veered drastically from what had started to emerge as the ideal of a good social system.

It seems that the socio-economic inequalities and differences were interpreted in the "solidarist" vein by those less favourably situated "at the bottom." Their interpretation was based on the common-sensical idea of justice and the conviction that the principles of social life should comply with this common sense. Whether one was a steelworker, a university professor, a shipworker or a teacher, one should have a feeling that one's position was equitable and warranted. And that was impossible in the system that denied voice to people and, thus, precluded a communal debate on their individual lives and collective fate. First and foremost, the laws on which the rules of life were based should conform to the citizens' will and values.

The common and equal law for all was supposed to institute and safeguard equal rules, enabling the citizens to arrange their lives and compete with each other for the positions they pursued in the social hierarchy. By the same token, solidarity was based on and evoked people's equal right to decide about their individual lives and collective life. In this way, Solidarity contributed to re-defining "politics." 
Politics could not be ignored when serious and responsible discourse commenced on how individual citizens could manage their lives. Responsibility for oneself and one's loved ones necessarily entailed developing and agreeing on the ways and rules of interacting with other people who, equally, cherished their own aspirations and pursuits.

For these reasons, the social movement that developed around and through Solidarity came to be called a civic movement. David Ost, an American researcher of Solidarity, considers the exceptional trade union to be a continuation of "the politics of anti-politics," as he dubs the strategies developed earlier by what came to be called the democratic opposition. Ost claims that Solidarity did not have either a full-fledged, firm political identity or a specific, recognisable agenda easily classifiable within the historical political traditions. The movement's leanings, as Ost states, were neither leftist nor rightist. The main goal was to foster possibilities for the citizens to have a say in the development, priorities and policies of the state, which represented society and protected citizens. ${ }^{11}$

Admittedly, Ost examined the divisions within and the inner diversity of the democratic opposition movement in the 1970s and the later ideological and political complexity of the Solidarity movement, yet his "anti-politics" highlighted, basically, a moral and ideological attitude which was shared by all the activists and shaped the way society thought of the goals of social changes.

Social transformation was impossible unless individual citizens and, subsequently, society as a national and civil collective regained their subjectivity. Antipolitics was possible because all social actors involved in the fight for freedom and democracy reached a unique agreement as to the fundamental moral values guiding them in their quest for a democratic state. There was thus "a value consensus" that underpinned the attitudes of solidarity shared by people who differed on more specific political matters.

The major point of the "anti-political politics" was to prevent any ideologically driven group, tempting though its agenda might have been, from imposing its will on the other ones and from monopolising the interpretation of social wishes, interests and shared values. No such group was supposed to become a self-anointed champion of "workers," "society" or "the nation." The nationcum-society itself was framed as free to decide whom and when to entrust with representing its interests and which solutions to adopt.

11 Cf. David Ost, Solidarity and the Politics of Anti-politics: Opposition and Reform in Poland Since 1968 (Philadelphia: Temple University Press, 1990). 
This new notion of politics showed that democratic society, based on human and civil rights, had its hidden moral underpinnings. Democracy became a dream of millions of people. The experience of living in a monolithic state governed by an autocratic party made them think of democracy, paradoxically, as impracticable without an underlying moral agenda.

Democracy means a pluralistic, diversified, stratified and even utterly fragmented society, where a myriad of discrepant tendencies are at work. In their daily practice, democratic societies also seem conflicted on moral principles and moral standards of life. Polish Solidarity surprisingly showed such diversified, disputing and eternally quarrelling communities a common moral foundation.

This moral bedrock was encapsulated in the notion of "civil society." Both Ost and another American scholar Michael Bernhard evoke this concept, which had hardly been used in social and political scientific studies before the 1980s. Still, this very notion proved indispensable to understand and give an account of Solidarity's democratic reform movement. ${ }^{12}$

Another surprising thing, which was to stir a serious intellectual debate later, was that the ideal of a society of free citizens animated not only Polish intellectuals (or, in broader terms, the intelligentsia), but also workers and so-called ordinary people, who adopted it as their own and relied on it to channel their aspirations. Politics trickled into their lives as a requisite component of the fully lived, responsible, adult life. Participation in politics as a common social debate on matters of interest to all came to be seen as a sine qua non of decent life and individual sense of civil dignity.

The subtitle of Bernhard's book lists side by side workers, intellectuals and oppositional politics in pre-Solidarity Poland. Both Ost and Bernhard try to explain how the ideals touted by a small and seemingly isolated group of dissidents were claimed by millions as their own and discussed by the masses. In their view, Solidarity as a trade union and as s social movement would not have been possible without the democratic opposition of the 1970s, mobilised around the Workers' Defence Committee (Komitet Obrony Robotnikiów; KOR) and assembling many other groups, such as the extremely important Movement for Defence of Human and Civil Rights (Ruch Obrony Praw Człowieka i Obywatela; $\mathrm{ROPCiO})$.

12 Cf. Michael H. Bernhard, The Origins of Democratization in Poland: Workers, Intellectuals and Oppositional Politics, 1976-1980 (New York: Columbia University Press, 1993). 
Ost, who sees a simple continuity between the democratic opposition and Solidarity, attributes the formative significance to the KOR and independent publishing promoted by KOR-affiliated circles. Bernhard, however, is far more tentative and, though he by no means ignores the contribution of the KOR and the entire democratic opposition, he understands that it took something more than just the independent press and books to disseminate democratic ideas. Therefore, he also lists the impact of the Church and the pro-democratic and freedom-focused Catholic ethos evolving since the late 1970s.

Jan Kubik's notion of the "ceremonial revolution" seems a very interesting interpretive approach. The revolution was "ceremonial" since no other one would have been possible, not only because of the system's overwhelming military and infrastructural advantage. The democratic values, strongly informed by religious - Catholic or, better, Christian - attitudes and motivations as they were, precluded, it seems, an armed revolution. Given that the "system" against which the opposition protested had been produced by the military Soviet revolution, a vast majority of workers and intellectuals simply recoiled at the idea of changing the system in any similar fashion..$^{13}$ Kubik's analysis is corroborated, to some extent, by the Church's persistent mobilisation of religion to encourage non-violent fight for human and civil rights, regarded as the natural, moral foundation of a good social system.

The "ceremonial revolution" is, so to speak, a vivid symbolic outline of a new social order that, to use a sociological term, delegitimised the previous, socialist system and invalidated its justifications and slogans. The project of a new order was not merely a figment of people's imagination or a drive behind their attitudes; it also materialised in joint action. The Solidarity trade union was a social laboratory for and a dress rehearsal of implementing the new principles as the basic structures of the state.

It is thus hardly a surprise that, in the title of Kubik's book, "the power of symbols" is juxtaposed with the "symbols of power," because history has showed, again, that raw power expressed in state violence against society is impotent against the power of innocuous symbols if only these symbols can re-forge a collective of individuals into a community unified by common bonds and an organised social movement.

13 Cf. Jan Kubik, The Power of Symbols and Symbols of Power: The Rise of Solidarity and the Fall of State Socialism in Poland (University Park: Pennsylvania State University Press, 1994). 
Solidarity's symbols delineated a special space which was permeated by a new social order - an outline of a new system, yet a project. But the revolution had already happened by then, sweeping across attitudes, beliefs, imaginaries and people's latent and explicit dreams and expectations. The compromised symbols of power and violence had to back down.

All the authors referenced above agree that the project would not have been possible without the democratic opposition's work, but it must be emphasised from the start that Solidarity and its trade union were not simply a continuation of any prior oppositional organisation; nor can any oppositional group (even the most distinguished ones, such as the KOR and the ROPCiO) be viewed as the sole source of fundamental ideas and social attitudes that coalesced into the vigorous civil project of a new social order. It still remains to be determined how precisely the democratic opposition and the Catholic Church's engagement contributed to the rise and work of Solidarity. Similarly, there are still more specific issues to be figured out, such as whether Solidarity's ideals picked up and applied the ideals of the KOR only or, perhaps, also of any other hubs of the democratic opposition.

As a matter of fact, it is no trifling question. It became particularly pertinent after 1989, when the Independent Self-Governing Trade Union "Solidarity" was re-activated, yet failed to become the chief axis of any mass social movement. Instead, various political groups and parties mushroomed, all of which drew on the symbol and the ideological legacy of Solidarity from 1980-1981.

This issue has never been thoroughly and objectively debated in Poland, excepting mutual accusations and insinuations levelled by erstwhile adamant friends and allies, now involved in a fierce political rivalry.

To return to Solidarity, a direct impact of oppositional thinking on the trade union's official agenda can likely be traced. But this agenda, though democratically adopted by Solidarity's Convention of Delegates (Zjazd Delegatów), cannot be equated with that "vigorous project" which fuelled the social reform movement and was symbolically practised within the trade union.

This observation is substantiated by a much earlier study which applied very original empirical research methodologies. Alain Touraine and his French and Polish colleagues set out to study and depict the ideals and action modes of the Solidarity movement. Touraine came up with the concept of Solidarity's distinctive "triangle" in which political, national and social goals were inseparably interwoven. Democratic state reform, national independence and self-governing society as the agent of power controlling the economy were the goals Touraine ascribed to Solidarity. 
Always evoked in one breath, they never appeared alone, and Touraine argued that disjoining these goals and actions would immediately result in the disintegration and decline of the Solidarity social movement. ${ }^{14}$ This seems to confirm that a holistic project of organising life in Poland was nursed in popular consciousness as well as in more organised forms of collective consciousness.

But who actually "authored" the project of the organisation of life which, as Touraine's study vividly shows, was being forged day in day out in incessant debates that pervaded the daily lives of workers, the work of the union's board and its press? Was it authored by workers or by the intelligentsia, or perhaps by intellectuals? Rumour about conflicts between worker-unionists and intellectual-experts was rife both when Solidarity operated legally and when, officially disbanded, it went "underground." Lech Wałęsa, the symbol of the union, was himself rather vocal about his anti-intelligentsia sentiments.

The question whether Solidarity was more "of the workers" or "of the intelligentsia" stirred a heated debate in the US in the early 1990s. Roman Laba and Lawrence Goodwyn, two major voices in the debate, each published a book entirely devoted to the issue in $1991 .{ }^{15}$ Laba had spent a few years in Poland collecting data for his study. That his book was released a few years after the author had returned to the US seems to have impacted its content: apparently, the account of Solidarity was incorporated into a broader theoretical and ideological discussion and coloured by the beliefs held by the author (or, rather, authors, for Goodwyn took a similar stance).

To recognise Solidarity as an inherent achievement of the working class and to trace it back to the reflection and values of the working class was germane to socialist or socialist-inspired theory and ideology. Communists are known to have assumed that, in their struggle to improve their lives, workers must be aided by the "ideologically sound" intelligentsia, who would "contribute" an appropriate socio-political consciousness (this is a crucial addition Vladimir Ilych Lenin made to the Marxian theory). Left to their own devices, workers could not develop a democratic consciousness, let alone create a just, socialist alternative to bourgeois democracy.

14 Cf. Paweł. Kuczyński et al., W poszukiwaniu ruchu społecznego. Wokół socjologii Alaina Touraine’a (Warszawa: Oficyna Naukowa, 1994).

15 Cf. Lawrence Goodwyn, Breaking the Barrier: The Rise of Solidarity in Poland (Oxford: Oxford University Press, 1991); Roman Laba, The Roots of Solidarity: A Political Sociology of Poland's Working-Class Democratization (Princeton: Princeton University Press, 1991). 
Solidarity was thus a case at which social democrats were all too eager to pounce: they could use the example of a powerful and, eventually, victorious social movement of workers to disprove the theses of Marxist-Communist political philosophy; more than that, they could show that workers aspired to democratic forms of socio-political life "all by themselves."

Involved in the socialist movement in his youth, Touraine only did research in Poland in industrial plants, and his interlocutors were chiefly workers, members of activist groups. But it was also evident to Touraine that Solidarity was an outcome of a rather extraordinary merger of workers' and the intelligentsia's ambitions, which seemed to build on the protests of 1968 (students and the intelligentsia) and 1970 (workers). In the early 1990s, US researchers and analysts did not realise that Solidarity could be associated with the experience of 1968 and 1970 , and their accounts were impacted by a specific context.

Goodwyn's and Laba's interpretations provoked polemics from other scholars, such as Andrzej Tymowski and Michael Bernhard, to mention just two of their critics. A Polish translation of Bernhard's text appeared in Krytyka, but it did not raise any special interest. ${ }^{16}$

In his exploration of the protests of shipworkers and other workers of the Baltic Coast region, Goodwyn argues that the 1980 revolt built on the experience of the 1970 strikes. It is a very tempting notion, all the more so that Lech Wałęsa has repeatedly referred to the events of December 1970 as formative of his mindset and his further life. I and my colleagues posited the same relationship when we commenced our research on new trade unions formed in Warsaw in 1980; earlier experiences could after all be expected to influence the actions and thinking of the working-class protesters. However, the issue proved far more complex. The texts compiled below will show that even if workers largely capitalised on the prior experience, in doing so, they tended to rely on general social memory and inspirations from the oppositional press. In fact, evidence of any direct influence of the people who had orchestrated prior protests, often in the same factories, and suffered for that, is nowhere to be found.

16 Cf. Michael Bernhard, "Nowe spojrzenie na Solidarność," Krytyka 38, 1992. Republishing this text, I need to mention an important critique of Laba's and Goodwyn's concepts offered by Kubik; cf. Jan Kubik, "Who Done It? Workers or Intellectuals. A Controversy over Solidarity's Origins and Social Composition," Theory and Society 23, 1994, pp. 41-66. 
It seems that the developments in Gdansk followed a similar trajectory; for though the Shipyard gate, where workers had been killed in December 1970, became a symbol, social memory only reclaimed this symbolic place years later.

It was only in the late 1970s, when oppositional organisations had already been firmly in place for some time, that attempts were made to commemorate anniversaries of the December events. Those celebration were suppressed by the People's Militia (Milicja Obywatelska) with greater or lesser ruthlessness.

Lech Wałęsa, himself a participant in the illegal celebrations, joined the preAugust oppositional unionist movement, but his engagement does not seem to have originated in his experience of December 1970. Rather, it seems associated with how December 1970 was re-worked by a new consciousness emerging towards the end of the Gierek epoch. ${ }^{17}$

In polemics with Goodwyn's and Laba's findings, other authors have often foregrounded the concept of "civic consciousness" as informing the pursuits of Solidarity. The concept holds that civic consciousness germinated at the onset of the formation of the unionist movement. The shipworkers who went on strike in the summer of 1980 and all those who later joined the Shipyard's mass strike did not seek their short- or long-term group interests, as had usually been the case earlier. While under Gierek striking had become a regularly used tool for improving the living standards of families, the strike in August 1980 was not devised in order to obtain from the government what the strikers wanted just for themselves, i.e. for particular worker groups or "industries" (though the official parlance of real socialism framed workers as a ruling class, with the PUWP ${ }^{18}$ and the Soviet CPSU governing on their behalf). The strike of the Gdansk Shipyard (which was still named after Lenin) quickly mutated into a more general, even nationwide protest. The strike committee at the Gdansk Shipyard included representatives of various enterprises based in Gdansk and, later, in the entire Tri-City. ${ }^{19}$ This only further shows that the shipworkers did not lay partisan claims but expressed demands and attitudes shared by many other workers who embodied the civic mindset. This mindset was confirmed when the release of a

17 The Gierek epoch/era/decade denotes the decade of the 1970, when the position of the First Secretary of the Polish United Workers' Party and, consequently, the leadership of the state was held by Edward Gierek. (translator's note)

18 PUWP stands for the Polish United Workers' Party (Polish: Polska Zjednoczona Partia Robotnicza, PZPR). (translator's note)

19 The Tri-City (Polish: Trójmiasto) is a collective name designating three coastal cities: Gdansk, Gdynia and Sopot, which form one urban agglomeration. (translator's note) 
dozen arrested opposition activists was included among the conditions to end the strike and to sign an agreement with the government, as the phrase used back then had it. This also shows how vitally the actions and demands of the workers and the pro-democratic intelligentsia were interlocked. Anti-intelligentsia sentiments were overcome in the name of civil community.

Yet were the attitudes of the workers' indeed so pro-democratic and did they view the new, just order as necessarily founded on individual civil rights? A relevant piece in this jigsaw puzzle has a national colouring and involves thinking in terms of "our" national interests as pitted against the Party and state interests of the People's Republic of Poland. As such, it concerns "them" who, at the time, had already come to be commonly identified as agents of the Soviet, if not Russian, interests. Solidarity activists dwelled on this issue repeatedly, both in public and in private everyday discussions. As the codename "geopolitics" enthused the public and individual imaginations, many people fantasised that if only Poland could be miraculously relocated on the globe, it would immediately turn into an entirely different country...

The idea of a national Poland, where only "our own people" could represent society and govern while "strangers" or "foreigners" were suspect and did not deserve the same civil rights as Poles, cropped up time and again in a variety of forms across the Solidarity-inspired masses. Towards the end of Solidarity's legal activity, a movement of so-called true Poles came into being and, with little success, tried to gain some influence with the Mazovia Region ${ }^{20}$ delegates in Warsaw. The movement received no support either from the top activists or from most rank-and-file members of the union.

A dislike of strangers, of those who were "not our own folk," also surfaced in anti-Semitic slogans or nation-centred ideas redolent of anti-Semitism. But such voices were hardly robust and often sounded peculiar. There were attempts to confront the anti-Jewish stereotypes with reality, but they stumbled upon a prosaic difficulty: members of Jewish communities were very hard to find. At the same time, the oppositional intelligentsia and the entire March generation shared, so to speak, their experience of the anti-Semitic campaign that had targeted their professors and friends in 1968. As a result, the discussions involving workers and intellectuals from the March generation could sound peculiar indeed, for the workers tried to find out how reliable or justified their familiar anti-Semitic stereotypes (part of their "natural" social knowledge) were. And because other

20 Mazovia (Polish: Mazowsze) is the name of the geographical and historical region where Warsaw is situated. 
cornerstones of popular knowledge had to be revised as well, the anti-Semitic stereotypes were not given much credence anymore. This conjuncture is quite insightfully described by Michel Wieviorka in a book that has never been translated into Polish (or English). ${ }^{21}$ It is a pity, for the ideas trumpeted by the "true" Poles in 1981 seem to have resurfaced recently (and with vengeance, too) and are rumbling across the re-established Independent Self-Governing Trade Union "Solidarity."

The national agenda was acknowledged in Touraine's study as one of the Solidarity movement's essential ideological investments. However, thinking in terms of national interests did not in the least contravene the universal principles of equal rights for all citizens, whatever their idiosyncratic, individual and group identities. It seems that, in the day, the "true" Poles were rather an exception, while the general ideological climate did not promote nationalist attitudes. The stance adopted by the Church, an active champion of human and civil rights as the foundation of the just social order, greatly favoured the democratic leanings in Solidarity's national thinking.

The problem of thinking in national terms and of guarding national interests is perhaps the least studied one in the literature on Solidarity, at least in the more recent publications. The theme is nonetheless relevant, and a thorough debate on it could spawn some new meanings and new symbols. Such meanings and symbols would certainly help give a well-judged expression to national traditions and interests, which are all too easily dismissed as a mere parochial prejudice by the progressive and liberal intelligentsia. Such a morally demeaning assessment of an ofttimes profound reflection on matters relating to Poland and Poles has done a lot of harm to us all over the years. $* * *$

In the foregoing, I attempted to list the most important points raised in recent years in discussions on Solidarity. By necessity, I have passed over earlier studies and only evoked the most important issues which still remain underexamined in Poland. In deciding to publish the handful of essays below, which accompanied, so to speak, collective actions and thinking, I was inspired by two phenomena. One of them was the staggering pace and the impressive compass of the process in which millions of people had constructed a grid Solidarity's units. The other was a perhaps even more puzzling process in which millions of Poles had forgotten about the Independent Self-Governing Trade Union "Solidarity" and their own Solidarity involvement.

21 Cf. Michel Wieviorka, Les Juifs, la Pologne et Solidarnosc (Paris: Denoël, 1984). 
This obliviousness is all the more surprising, given that in the second half of the 1990s, a few years after Poland had gained democratic sovereignty, the political movement looking back to Solidarity and revolving around an Independent SelfGoverning Trade Union was revived. But this is an entirely different Solidarity; its political ideals deviate from those cherished in the 1980s. This volume can serve as a mirror showing uncanny meanders of history, human lives and human ideas. Perhaps it will help restore social memory of the events that once shook the world.

Warsaw, April 1997 



\section{Part One The Way It Was: Solidarity and Empirical Sociology}

Part One of this book reports on the findings of a sociological study on the formation and rise of the Independent Self-Governing Trade Union "Solidarity" in Warsaw. The bulk the study was conducted in the autumn of 1980 while the last interviews were administered in early January 1981. The idea of the study sprouted in October 1980 and was partly inspired by Professor Stefan Nowak of the Social Research Methodology Chair at the Institute of Sociology, University of Warsaw. Our team's report, entitled Polacy - Jesień '80. Proces powstawania niezależnych organizacji zwiazkowych (The Poles in the Autumn of 1980: The Rise of Independent Trade Unions), was only published at the University in 1983 as a special edition bypassing state censorship. Its print run was 100 - one hundred - copies. This was given as the official number in order to conform with the regulations in force then, but, in fact, twice as many copies were printed. The research team that contributed to the final publication included Grzegorz Bakuniak, Iwona Jakubowska, Anna Kruczkowska, Ireneusz Krzemiński, Jan Poleszczuk and Henryk Banaszak, who analysed the press of the "hot summer" of 1980 for us.

The key chapter of the 1983 report, accompanied by a methodological introduction, makes up the core of the first part of this volume. The introduction explains how this author conceived of sociology back in the day, which, as a matter of fact, does not differ much from his current ideas.

Parts of the study appeared in samizdat journals and, then, in regular journals in 1997, followed by a complete Polish edition in $2005^{22}$ within the series of Socjologia niezapomniana (Unforgotten Sociology), edited by Antoni Sułek and published by the Institute of Sociology, University of Warsaw. The series included sociological studies released by samizdat publishers in the 1980 s.

22 Ireneusz Krzemiński et al., Polacy - jesień '80, Socjologia Niezapomniana, vol. 3 (Warszawa: Wydział Filozofii i Socjologii UW, 2005), 420 pp. 



\section{"Hot Sociology": Research Assumptions and Procedures}

The idea of the study germinated in October 1980. Our team's major research aim was to trace the formation of trade unions which had been mushrooming in and around Warsaw since September 1980. In our project proposal, we wrote: "The situation is a novelty to our society and fosters a new social experience as well as offers an opportunity to augment sociological knowledge about Polish society in particular and theoretical knowledge of social mechanisms in general." Further, we formulated our central research aim: "The study we envisage aims to do more than just improve academic knowledge of society as the data we will generate are also expected to help us understand the currently developing and anticipated social actions. As such, the knowledge yielded by our study will be hot knowledge and itself part of the studied social process." As can be seen, our idea was to inform decision-making agencies and the broad public of the findings gleaned from the study in progress. Our model of social sciences differed, thus, from empiricist sociology. Regrettably, we did not quite make good on our promise. The report on our findings was only completed in the spring of 1983, when the social conjuncture was radically different from the autumn of 1980 and from the vistas it had seemed to augur.

\section{Workplace-Based Communities: The Selection Criteria}

In our study, we planned to examine the formation process of trade-union institutions in various enterprises. We selected a sample of eleven enterprises based on a few intersecting criteria. Firstly, they were big industrial plants of special economic - and, consequently, social and political - relevance, particularly those whose workforce were a significant factor in the trade union development in the region. For the sake of contrast, we also included small enterprises which had joined the unionist initiatives relatively late. Secondly, they were big enterprises from the capital city and enterprises of a comparable size from the surrounding area. Thirdly, they were organisations that employed either mainly men or mainly women. Fourthly, they were industrial plants where most of the staff were workers and enterprises where university-educated employees were in the majority. Fifthly, they were manufacturers and service-providers in the capital (e.g. CHPs and municipal transportation service). 


\section{The Multi-Perspective Research Design}

Within each enterprise, we studied all the organised actors of the unfolding social process. This meant that we examined the actions and views of: 1) directors; 2) secretaries of the enterprise-level PUWP ${ }^{23}$ units; 3) leaders of the enterprise-level boards of the old trade unions (branch unions); 4) leaders of youth organisations $\left(\mathrm{ZSMP}^{24}\right)$; 5) heads and other members of the Enterprise Committees of the NSZZ "Solidarity"25;6) leaders of other newly established trade unions in respective enterprises (the unions were typically referred to by our interviewees as "directorial," though at the time of the study they were commonly called "autonomous trade unions"). Our object was to look at the events preceding August 1980 and the social process unfolding ever since through the eyes of all the social actors involved.

We wanted our interviewers to contact the initiators of the Founding Committees of the NSZZ "Solidarity," that is, people who were the driving force of social actions (this also held for all other newly set up trade unions).

The autumn of 1980 was also a time when old organisations were adjusting to the new circumstances. In particular, the old trade unions, which were assembled in the CRZZ, ${ }^{26}$ were transforming. Our interviewers went wherever change had taken place and interviewed both the new heads of Enterprise Councils and their predecessors who had been in office in August 1980.

Besides, we planned (7) group interviews with representatives of workforce in order to get at least a fragmentary insight into the views of "ordinary" workers.

The interviewers stumbled upon some difficulties when trying to interview the directors. In two cases, the directors not only refused to be interviewed but also did not permit us to collect our research data in their enterprises.

The enterprise-lever PUWP first secretaries often declined to be interviewed, delegating other people instead. In three enterprises, the secretaries refused very firmly. We managed to interview two ZSMP members.

23 PUWP stands for the Polish United Workers' Party (Polish: Polska Zjednoczona Partia Robotnicza, PZPR). The Party's lowest organisational unit was called the Basic Party Organisation (Polish: Podstawowa Organizacja Partyjna, POP). POPs were set up within every office, factory, enterprise, etc. (translator's note)

24 ZSMP stands for the Związek Socjalistycznej Młodzieży Polskiej (Polish: Polish Socialist Youth Union). (translator's note)

25 NSZZ is the acronym for the Niezależny Samorządny Związek Zawodowy, i.e. the Independent Self-Governing Trade Union.

$26 \mathrm{CRZZ}$ is the acronym for the Centralna Rada Związków Zawodowych, i.e. the Central Council of Trade Unions. 
The data we collected also include (8) interviews with members of the post1976 democratic opposition.

Another set of interviews (9) includes interviews with the founders and activists of the Independent Self-Governing Trade Union of Scientific, Technical and Educational Employees (Niezależny Samorządny Związek Zawodowy Pracowników Nauki,Techniki i Oświaty, NSZZ PNTiO), which was an organisation of Warsaw's intellectual community, established concurrently with the NSZZ Mazovia. The NSZZ PNTiO, which enjoyed immense popularity in the capital, self-disbanded at the $2^{\text {nd }}$ General Convention, and its units were incorporated into the structures of Solidarity's Mazovia Region. Our interviews about the $\mathrm{PNTiO}$ activities were administered slightly later than the other interviews.

\section{Competent Informants and the Main Research Questions}

The interviewees were our competent informants. We expected our collection of interviews to help: 1) trace back the formation process of the new societal institution and identify factors conducive or adverse to the establishment of independent trade unions; 2) determine what previous social experiences and prior involvements underpinned current activism; and 3) depict the response of the "old structures" to the rise of a new trade-union institution.

The respondents were, consequently, also researchers who were expected to describe their own and their partners' pursuits as well as to depict the behaviour of their opponents and the prevalent way of thinking within their enterprisebased community.

The (multi-perspective) research design enabled us to analyse each social actor's activities, based on the comparison of self-reports from various participants in the studied events. Overall depictions of respective enterprises could be produced in this fashion, too. Even though our data were incomplete and statistically non-representative, they made it possible to test the reliability of our competent informants regarding people's general views.

In this way, we sought to offset the impact of what Hans Speier called social perspectivism, ${ }^{27}$ which we could expect to encounter in interviews with the "formal" and "spiritual" leaders of enterprise-based communities.

27 Zagadnienia psychologii społecznej, selected and edited by Andrzej Malewski (Warszawa: PWN, 1962). 


\section{Research Methods: The Epistemological Underpinnings}

Yet, truth to be told, we wanted primarily to find out about individual actors' unique social perspectives on the developing situation. While the external criteria helped us control, to a degree at least, the image emerging from our respondents' reports, they did not serve us to substitute our "unbiased," "scientific" competence for our subjects' participation-based competence.

We assumed that the functions our competent informants performed in social life predestined them for the role of natural social researchers. We concluded that, in what they were doing, our competent informants had to objectively monitor their own actions as only by adopting such an objectivising and rationalising view could they maintain their position in the system of collective pursuits and make sure that their community's efforts were effective.

The objective view of what is going on and what I take part in only becomes meaningful when juxtaposed with the perspective in which I-am-the-one-thatacts or we-are-the-ones-that-act. This particular perspective is a sine qua non for grasping the totality of the social process at hand. This seems to be a prerequisite for objective sociological knowledge.

In such scientific knowledge, ramifications of social perspectivism are not just a source of "cognitive errors" for the sociologist; rather, social perspectives which evolve in social life make up the basic object of sociological research.

Sociologists usually describe social developments as objective and produced by an objective set of intertwined factors. ${ }^{28}$ People's actions are identical with behaviours, that is, with behavioural responses to the stimuli to which people are exposed (called conditions or correlates in sociological research). Action is conditioned by the environmental patterns external to people and is itself subject to mechanisms independent of people's will, for example systemic factors. On this model, such patterns, regularities and factors can only be fathomed by a researcher who investigates them from outside of the process.

Designing our research, we concluded that to adopt such a point of view would be self-defeating in terms of our intent to provide an effective account and an adequate explanation of social reality, all the more so because the autumn of 1980 saw Polish society faced with a highly problematic situation.

28 Durkheim's central rule to treat social facts as things seems to be the still unshaken basis of empirical sociology. 


\section{Basic Theoretical Assumptions: Symbols and Actions}

Theoretical underpinnings of our research design were derived from symbolic interactionism, which did not preclude the use of other theories for data interpretation.

Put very simply, our theoretical assumption was that, as a rule, the social world seems as permanent as material objects to people. The social space does not differ much from the physical space. Yet, every now and then, this stable social world disintegrates before everybody's eyes or, alternatively, people themselves decide to change it. The previously taken-for-granted form of social phenomena suddenly becomes problematic, while the so-far latent foundations of the stable structures are exposed. Participants in these events begin to realise that natural and social objects necessary to or facilitating life are available because of a complex network of collaboration whose principles are by no means evident or "natural." 29 In such moments, objective sociology as such also becomes problematic.

A problematic situation reveals what we are oblivious to in daily life, i.e. that what we take for a stable social world is, in fact, a continually unfolding process within which we align our actions with the actions of other people. The problematic situation also shows that social reality is a symbolic reality. The continuity of behaviours and the stability of the social world depend on the durability of spiritual forms and modes of thinking that use such and not any other symbols.

We struggle to grasp the suddenly "problematising" reality until we find new symbols to frame the situation as a form, that is, as having a certain order (and thus being a "situation"). The symbols trigger a social process, for they compel people to re-assess the situation and re-invent themselves as seen by themselves and others. This helps people comprehend how the new situation is related to their conduct and to the goals they cannot possibly abandon. This reflection represents the first step in the new social process.

29 "Societies develop just as animal forms develop, by adjusting themselves to the problems that they find before them," writes George Herbert Mead: "Living forms have found themselves up against problematic situations: their food gone, their climate changed, new enemies coming in. The method which nature has followed, if we may speak so anthropomorphically, has been the production of variations until finally one variation has arisen which survived. Well, what science is doing is making this method of trial and error a conscious method"; George Herbert Mead, "The Problem of Society - How We Become Selves," in George Herbert Mead, On Social Psychology, ed. Anselm Strauss (Chicago: The University of Chicago Press, 1972), pp. 24, 25. 
How people make sense of the world is conveyed in significant or meaningful symbols, as George Herbert Mead explains. ${ }^{30}$ We depend on symbols in two ways, i.e. as on tools, units of exchange in the communication process, and as on things and thought-objects that present the world's real meaning to us. We can take various positions vis-à-vis symbols and rely on them to anticipate in our minds the consequences of behaviours in order to select optimal responses. For concepts to adequately represent objective meanings in our minds, the participants in events must share the same significant symbols. In this context, sharing means adopting similar attitudes to situations and using the same symbols as "others" do to choose what to do next. The rationality of action hinges thus on the scope and intensity of human communication. Our action depends on symbols which our thoughts use and, consequently, on our bonds with others, which are based on the fact that we communicate.

Cooperation is a spontaneous process of adjusting individual behaviours. It is directly predicated on mutual communication and free, ongoing discussion. Common action entails common thinking.

How the social process develops depends on well-informed decision-making of human agents. Consequently, all social phenomena, including mass ones, result from the system of common actions initiated and controlled by social actors. These "social actors" form an organised community. ${ }^{31}$

\section{Research Method: The Insider's View}

As implied by the argument above, popular reflection, at least in problematic situations, involves the cognitive effort of focusing rationally on one's own activity in the world. Sociological reflection, so to speak, "extends" and "abstracts" the cognitive social process of popular reflection. Popular reflection and scholarly reflection are similar in that they are both forms of human self-awareness which must take others' awareness into account as an element of the world. When making sense of social experience, a social researcher must necessarily refer to experiences of his/her subjects in order to produce an account of the social process as viewed by its actors. S/he must thus adopt an insider perspective to capture the totality of human experience as "an object" to which

30 For a discussion of significant symbols, see George Herbert Mead, Mind, Self and Society, ed. Charles W. Morris (Chicago: University of Chicago Press, 1972), pp. 69, $71-72,73,181 \mathrm{n} 7$.

31 In this text, the social actor is understood similarly to the generalised other in Mead, but the two notions are by no means identical (see Mead, Mind, pp. 153-156, 161-164). 
the actors themselves responded and which is also external to those who will develop this experience. Sociological knowledge is therefore, like all science generally is, a link in the social chain of human life. This assumption guided our approach to our study as production of hot knowledge.

Adopting the insider's view is a prerequisite for reliable sociological knowledge. Rather than from the "outsider observer's position," "unbiased judgment" results from efforts to understand all the actors involved in a social process. This does not entail that researchers accept the actors' statements at their face value. Of course, there is no reason not to trust them, but equally there is no reason to naïvely believe them. Research conclusions are actually formulated by comparing reports of informants who view the same events from different perspectives.

Our respondents were not simply representatives of organisations. During the interviews, they articulated various viewpoints on the issues under investigation, depending on their actual or potential positions in the network of interactions developing in the mainstream of social action. On some occasions, they spoke in terms of the function they performed in the collective venture, expressing common interests and values; on other occasions, they spoke in personal terms, expressing individual perceptions which were determined by their mental traits and specific biographies; and in yet other moments, they interpreted the joint action in terms of the national tradition and its legacy. There were, of course, more perspectives and roles of this kind. By confronting various viewpoints of respective respondents and comparing them with reports of other subjects, we could distinguish self-aware reflection which rendered immediate experiences in general language from systematising interpretations which used symbols and "stereotypes" of popular knowledge and conveyed social experience in hindsight.

This point is well illustrated by an example from the interviews with the founders of the Independent Self-Governing Trade Union of Scientific, Technical and Educational Employees, which sheds light on the formation of independent trade unions as such.

Asked what people initiated the establishment of the independent trade union, a respondent answers: "Generally, there was a pattern to it [...] Research workers were as a rule young people. I mean, people of my age, twenty-somethings to thirty-somethings. At most. And educational workers were chiefly older [...] people from the National Museum and the Warsaw University Library, they were, let's say, middle-aged ladies"32 (NTiO, E,

32 The passages from the interviews are translated so as to approximate the respondents' original idioms, with all their grammatical, lexical and stylistic idiosyncrasies. (translator's note) 
pp. 7-8). ${ }^{33}$ Our respondents often repeated that Solidarity was a movement of young people. The respondent quoted above starts from expressing the same view, goes on to say things that seem to contradict this statement and, nevertheless, finishes restating that the majority of union founders were young people. That particular respondent actually belonged to a multi-generational group of union founders, which was a less frequent case in our sample (such groups generally tended to include people from the same generation). Asked to describe the initiators of social activity, our respondents as a rule answered: they were young people. The view was usually prompted by the "general traits" of youth: the young are more courageous and better educated, they know better, do not have families, have little to lose, are romantic and have not gone through as much as we, the older ones, have; they are rebellious and believe they can make change. These "positive" justifications were almost invariably intertwined with negative assessments: the young are irresponsible, imprudent, short-sighted, etc. When the opponents of Solidarity used the term "young initiators," they usually gave it a very pejorative ring.

Nevertheless, the stereotypical view that Solidarity was founded by the young is entirely untenable. Nearly in all cases, there were people from various age-groups among the founders; according to our estimations, the first union activists were aged 25 to 40 years old, or even 25 to 50 years old. Our data do not support more accurate estimates. Nonetheless, there certainly was an upper age limit to engagement in social activity. (Conventionally speaking, it stood at "around" 55 years of age. This limit is very conspicuous, with hardly any older people found to be actors of the studied social action, at least in Warsaw). On the other pole of the age axis, the youngest generation of the labour force, both workers and intellectuals, certainly did not initiate trade-union activities. ${ }^{34} \mathrm{In}$ fact, the youth, though popularly gestured at as the leading protagonist of the events, engaged in these events as rarely as people on the verge of retirement, at least in the first stage of the studied process. Interestingly, "the rebellious young" or "the courageous young" is the only social description of the initiators of independent trade unions available in our data. "I saw those people for the first time in my life. And I only knew them by the colours of their jumpers. It was even

33 See the note on citations at the end of this section.

34 Of course, members of the intelligentsia, included into this category based on the "mechanical" criterion of education, achieve independence and full social maturity later than young workers. We take this age-shift into account in all our observations throughout this chapter. 
difficult to know where they were from [i.e. from which enterprise], who the speaker was, even though they had to introduce themselves, and this rule was observed, but even if it was observed, everything was drowned in that clatter, in that noise, truth to be told" (NTiO, C, p. 5). This is how an "older" colleague of the NTiO member quoted above describes people who took the floor during one of the first organisational meetings and were, undoubtedly, initiators of the movement. The respondent immediately proceeds to give this experience an ordered structure and offer the familiar interpretation which identifies this random "medley of people" as the youth.

A ready-made cliché and a convenient "stereotype" help generalise experience and make sense of reality. Yet why was this particular cliché applied while it was so easy to prove it false? Our respondent goes on: "Absolutely, the youth prevailed, the youth in terms of age and the youth in terms of work, junior research workers, junior teachers ..." (Ibid.). This sheds light on the social classification of the trade-union initiators as the young. They were young in the sense of "junior" as typically used in bureaucratic parlance: a junior research worker could equally be 24 years old or 35 years old. In this framework, the category of "adulthood" practically disappears as people are considered either young (junior) or eminent, which is synonymous with distinguished old age.

Thus the interpretive cliché acquires a specific meaning which, nevertheless, does not abolish the original sense of the word. The utterance becomes ambiguous, and to understand it, the duality must first be illuminated. It must be taken it into account that, within the network of institutional relations, junior researchers are viewed as the young, no matter whether or not they are classified as such in any other setting.

Another reason behind the pervasiveness of this cliché is to be found in workers' interviews. (Nonetheless, the bureaucratically defined "youth" is also likely to be at play here.) It seems that young age is associated first and foremost with moral courage, disobedience and resolve to implement one's ethical ideals in the world. The categories of "adult" or "middle-aged" seem to be gradually dropped out of the social circuit. "Middle age" tends to playfully describe an aging person rather than to designate the period of social potency, maturity and robust life.

However, the use of the "youth" label is telling in that it reveals another truth about the studied events. Its ubiquity points to what people believed to be requisite for social activity and suggests what obstacles people had to surmount to engage in action. First of all, they had to overcome their fear of politics, ${ }^{35}$ which

35 The issue is aptly presented in our colleagues' research report (see "Lęk i zniechęcenie główne regulatory działań w sferze życia publicznego," in Mirosława Marody et al., 
involved the dread of any spontaneous social activity. Besides, they had to revise their stereotype that active involvement is a thing for the young, who, though daring, are also rash and reckless.

Such analysis must use the data which are generated based on the insider view revealing the interplay of people's relationships and interactions as well as the interplay of relevant interpretations. The respondent-informants' accounts of actions can then be juxtaposed with their understandings of these actions. This yields a sociological picture which, as opposed to empiricist sociology, does not flatten reality but, instead, conveys the depth and dynamic tensions of the social world. Such is, after all, the social world we all inhabit.

\section{Limitations of the Study}

Of course, our methodology entails various limitations. First of all, our findings concern spontaneous activities around the establishment of an independent trade union. As such, the study certainly does not provide a complete sociological picture of the social situation in September-December 1980, especially if the social situation is understood as a sociological depiction of the state of society. We were interested neither in society's state nor in its structure; instead, our focus was on the social process of changes in society's state and on the movement for re-structuring it, that is, the phase of building new social structures.

Hence, the situation and the state are rendered in categories which refer, as Mead would have said, to the universe of discourse constructed by the movement itself. This is an important limitation; our aim was to describe the situation vis-à-vis and within which the subsequent phase of the movement took place, in terms of the meanings which the actors involved accorded to this situation as an objective one.

We can easily imagine an observer who looked at all this differently, for example within the framework of "scientific laws" or "the laws of history." In such a case, the researcher would explore whether and in how far the social situation and its transformations conformed to the pre-defined objective theoretical categories. The research field would not overlap with the meaningful field of social experience. As such, it would have to be initially manipulated to become the researcher's empirical field.

Polacy' 80: wizje rzeczywistości dnia (nie)codziennego [Warszawa: Instytut Socjologii UW, 1981], pp. 117-136, and the 2004 re-edition, pp. 110-126). 
Of course, I do not deny that such a sober, "external observer's view" of the social situation described here has its advantages. In particular, it could identify the compass of the social process over time. In our study, we follow those people whose social behaviours triggered adaptive responses of other groups which either joined or tried to thwart common action. Metaphorically, the social process can be compared to the ripples expanding in circles across the water. We focused on what triggered the consecutive stages of action and mobilised new social groups, even as this action still developed. But in this way, we were not able to study the social field which was not drawn within the process. And this does not only mean all those who were the passive "audience" of the social spectacle, for they did take part in it exactly in the capacity of the audience. This means, first and foremost, outsiders who entirely stayed out. This means a social field unaffected by the huge movement and living in its own rhythm.

Admittedly, such outsiders were few and far between, especially in the autumn of 1980. Nevertheless, our study does not provide any data about the size of this group. All beliefs about it remain, consequently, purely conjectural. This is a fundamental limitation of our study which, importantly, becomes increasingly relevant in retrospect.

Our findings are typological generalisations and, as such, "models" of phenomena in which "individual" social experiences are expressed in universal language. This language is more general than our empirical data. When we posit, for example, that the generation of March'68 and the generation of June'76 were particularly instrumental in the founding of independent trade unions, this hypothesis is empirically valid for Warsaw and its surroundings. As our data were only collected in the Warsaw area (not to mention that they were not quantifiable), we cannot define the geographical applicability of our hypotheses. For example, we are unable to state whether our generational hypothesis also holds for the population of Gdansk. Actually, we could reasonably assume that the generational configuration in the Baltic Coast region was more complex. We could presuppose that a form of generational consciousness was shaped in the region by the December'70 events, even if this consciousness did not produce a uniform generational group. It may also be the case that such a group was crucial to the strike movement and later developments in Gdansk, Gdynia and Szczecin. We are unable to determine in how far these and similar hypotheses are substantiated. Finally, at least some of our hypotheses do not have strictly fixed time-frames. Undoubtedly, the formation of Solidarity's units and branches was a multistage process. Our generalisations, though proposing an overall depiction of the social movement, as a rule concern its first stage. Drafting our report, we already looked at the entire process through a historical lens. Consequently, we 
could be accused of failing to offer at least a tentative concept of how exactly the Solidarity movement developed. For if we believe that it developed in stages, we could be expected to express this belief discursively. That we have not come up with such a model is our clear theoretical limitation.

As a result, our image of the social process is interrupted and lacks a "natural" closure. Yet, the history of the huge social movement of Solidarity still continues. As Gestalt scholars say, it is an "incomplete figure." Instances of stylistic awkwardness in the interviews and the incompleteness of our argument are, by the same token, a peculiar rhetorical device that bespeaks the drama of social processes.

\section{Note on Citations}

This chapter contains ample quotations from our interviews. As a rule, they are the words of our respondents, unchanged in transcription and quoted verbatim. Omissions are marked with [...]. Explanations and additions from this author and, sometimes, from the interviewers are also bracketed. Citations contain the interview number (ascribed to the interviews on being delivered by the interviewers), preceded by the indicator of the respondent group ( $\mathrm{S}$ - NZSS "Solidarity"; P - PUWP; D - management of the enterprise; B - Enterprise Council of the old (branch) trade unions; R - workers/group interview; $\mathrm{NTiO}$ - Independent Self-Governing Trade Union of Scientific, Technical and Educational Employees; other organisations are identified by their acronyms). Citations also include the page number of the quoted passage. In some cases, citations start from additional letters (A to K), which designate the respondent's enterprise. Letters without numbers mark interviews with members of the democratic opposition.

Warsaw, 1983 


\section{The Rise of the Independent Self-Governing Trade Union "Solidarity"}

\section{Celebrating the Agreement}

The signing of accords in Gdansk and Szczecin was a moment of relief and joy. It opened up opportunities for spontaneous social action. For many groups and individuals, it was a time of collective celebrations of a settlement reached by the government and the representatives of society, whose demands embodied the communal will and attitudes prevalent in Polish society.

The experience of this festive celebration involved several different feelings. First of all, it was the celebration of the triumph of collective will and collective reason over the will and reason of the government, which not only made up a social minority but also had long and consistently disregarded society's opinions and needs. That government had ignored people, which practically belied its competence to make decisions about the fate of the social body. Secondly, society celebrated the newly regained dignity of people who had been a collective object of the government's doings. The reclaiming of dignity was associated with the reappraisal of membership in society and citizenship, which was again available to people as conscious and responsible subjects of social action. In being members of society and citizens, individuals had the right to engage in social action and to assess others' actions publicly. This had twofold consequences: the individual was entitled to make claims on other society members, and, at the same time, the individual was entitled to make pronouncements about the principles underlying society as a whole. By signing the agreements with the Government Commission, the striking workers of the Baltic Coast accomplished two feats: they won their struggle for workers' interests, and they asserted their right to act as citizens. For this reason, thirdly, while celebrating the accords, people manifested and relished social bonding. In workers' view, "our own" workers had won as advocates of collective interests, values and will. For the huge masses of non-workers, the workers had won "for us" (or, even, in our stead) as representatives of society and citizens. In both cases, this perception produced strong bonding emotions. Rooted in the direct or indirect victory of "our own people," the experience of bonding heralded the first positive sentiment felt towards the regime in long years. Fourthly, the celebration involved a paradox of the government winning in defeat since, in losing, the government 
gained social credit. Because the idea of negotiations and compromise prevailed over the idea of repressions and confrontation, the Party and state authorities garnered some social approval. That the regime transmuted into party-and-state authorities was no coincidence, for power-wielders came to be viewed as recognisable individuals with distinct social roles, functions and competences. In most general terms, the image of the until-then largely anonymous regime symbolised, at its most personalised, by the First Secretary of the PUWP's Central Committee - the vague and indeterminate image of governing "them" - was shattered. "They" turned out to be a diversified and complex group of people whose actions were determined by a variety of functions, hierarchies and interests - briefly, by an ensemble of specific and decipherable social roles. The signing of the agreements showed that the government could act not only in its own interest (imposed on society and articulated as the objective interest of the state and the nation), but also for the good of the society. In this way, a sense of communality was bred: our interests might still differ from theirs, but this difference (fundamental though it might be) was subsumed within an even more elementary, general community. There was a primary plane where we were all "us" ("we've come to terms like a Pole with a Pole"), while differences were secondary offshoots.

Fifthly, the signing of the accords was a festival of nationhood. It marshalled the central symbolism of national tradition, crucially including the religious tradition and Catholic symbols. The celebration robustly showcased and honoured the national identity. This only bolstered what is described above as personal dignity restored to people as society members and citizens. An entirely new meaning was conferred on society as a result of that experience of national identity, even though society as a community of citizens and agents co-responsible for the social body is not identical with the nation as such.

However, the sense of national belonging clearly reinforced people's selfexperience of subjectivity and "membership in society." All this resulted in the sixth factor: the cessation of fear. The signing of the agreements was a great festival of relief, of breathing freely and releasing enormous energy, which had been paralysed and consumed by dread before. Although the accords did not entirely eliminate anxieties and distress, they transformed these sensations by alleviating that fear which had pervasively saturated all fields of action, even though one could never put one's finger on it. For this reason, the signing of the agreements in the coastal cities did not simply spark celebration, but also marked the moment when extraordinary social pro-activeness erupted and gave rise to the nationwide Independent Self-Governing Trade Union "Solidarity" in late September. 


\section{The Explosion of Self-Organising}

"The work of trade unions in the People's Republic of Poland has failed to meet workers' expectations and hopes. It is therefore considered necessary to establish new self-governing trade unions to authentically represent the working class. Thereby, people's right to remain in the present unions is in no way questioned, and a possibility is envisaged for the old and the new unions to collaborate in the future" (Paragraph 1 of the Agreement between the Governmental Commission and the Inter-Enterprise Strike Committee, concluded at the Gdansk Shipyard on $31^{\text {st }}$ August 1980).

Human memory is fallible. In several interviews, our respondents repeat that establishing independent, self-governing trade unions was from the very beginning about building the nationwide Independent Self-Governing Trade Union "Solidarity." It is not true. What is true, however, is that in most cases when an independent trade union was set up, the underlying idea was to build a big organisation extending beyond one factory or one voivodship (province) and onto entire society. In Warsaw - or, speaking in terms of Solidarity's topography, in the Mazovia Region - first Independent Self-Governing Trade Unions came into being as early as four days after the Coast accords had been signed.

"After the signing of the agreement in Gdansk, we were advised to contact Gdansk about our trade union. But we decided to self-organise. When we returned from Gdansk, the WSC [Workers' Strike Committee] became part of the Founding Committee. On $1^{\text {st }}$ September, we went to the director and told him we were setting up an independent trade union. On $5^{\text {th }}$ September, we showed the director the Mazovia statute. He called in a lawyer, hoping that the lawyer would say it wasn't a statute. But the lawyer said, if people had signed it, it was a statute. The director had thought that it was only a draft, so short, merely two pages. Oh, and on $4^{\text {th }}$ September S. [the PUWP Secretary at the Ursus Machine Factory] chased us away from the office building, saying that if we didn't leave, the militia would come in within half an hour. There were about fifty people there, delegates of the MZK, the $\mathrm{FSO}^{36}$ and Ursus whod come for the Mazovia founding meeting. And they agreed on the name Mazovia there. So we left and signed the statute outdoors" (S 35, p. 4). This is how the first workers' trade-union in Warsaw came into being.

36 MZK stands for the Miejski Zakład Komunikacji, i.e. City Transportation Services. FSO stands for the Fabryka Samochodów Osobowych, i.e. the Automobile Factory. (translator's note) 
"This started on $2^{\text {nd }}$ September [...] On the $2^{\text {nd }}$, I went to the KIK [Club of Catholic Intelligentsia], where a friend [...] of mine [...] works for the editorial board of Wiezz. ${ }^{37}$ And the first thing you could get there, from them, was, exactly, explanation. I got a note there about what the ILO Convention 87 was, citing the relevant paragraphs [...]. And there [...], at the KIK, I also met Ms. B. S., I guess, and it turned out that [...] thered be a meeting at a private home [...], and people from a few departments were coming [...] to set up an independent trade union. The whole point was that we didn't know at the beginning whether the agreement signed in Gdansk only concerned Gdansk, only the Coast, or whether it was valid nationwide [...]. The thing is that even before that happened [the meeting in Hoża Street], something similar had already been formed at the Polish Academy of Sciences, that first organisation only called the Independent Self-Governing Trade Union of Science Workers. It took place on $3^{\text {rd }}$ September [...]; things were happening at a mad pace, because on the $1^{\text {st }}$ the agreement was signed, and already on the $4^{\text {th }}$ the first meeting was held. I suppose there were about sixty people there [...] my colleague P., who chaired the meeting, proposed that all those present at the meeting were the founding committee $[\ldots]$ and resolved to establish the Independent Self-Governing Trade Union of Employees, and I'm not saying what employees, for people disputed it" (NTiO 49, pp. 2, 3, 4). Eventually, the trade union was named the Independent Self-Governing Trade Union of Scientific, Technical and Educational Employees and came to be popularly called the nine-letter union (as its acronym in Polish was NSZZ PNTiO).

The two unions "met" on $4^{\text {th }}$ September, though, as our respondent describes it, the encounter was not particularly propitious: "[...] around eleven, or twelve at night, I guess, a man from Ursus rushed in [...] it could have been Bujak, but I can't vouch for that though I'm almost sure it was Bujak [...] And he announced that today, exactly on $4^{\text {th }}$ September, a Mazovia trade union had been founded [...], so he rushed in and said: 'Listen, stop debating; the Mazovia trade union was set up at a meeting held in [...] There were representatives of Ursus, the Warsaw Steel Plant [this bit of information is not accurate; numerous other interviews in our study indicate with absolute certainty that no delegates of the Warsaw Steel Plant attended the Mazovia founding meeting], the TEWA, ${ }^{38}$

37 A highly respected Catholic opinion magazine on political, social, cultural and religious topics. (translator's note)

38 TEWA was a Warsaw-based electronics manufacturer producing semiconductors and microchips. (translator's note) 
I guess, and a few other factories, and we nearly set up the Mazovia trade union, which is a branch of Solidarity in the Mazovia Region. ${ }^{39}$ So he got asked first 'What does nearly mean?' 'Well, as the things panned out', he replied, 'the FC [Founding Committee] were driven away from the room by our first secretary'. So, well, there were laughs, laughs [...], for it sounded kind of silly. People were quite sceptical about it" (Ibid., p. 6).

That scepticism may seem unfounded now, but the initiators of the tradeunion founding movement had absolutely no idea how rapidly the society-wide process would unfold and how many people would be drawn into it. At the same time, the fear of reprisals expressed by the newly-founded Mazovia members sounded misguided to the research workers for, as our respondent put it: "Things were happening in a really spontaneous way and [...], at least that was my impression, how would the Security Service or other services track down people when three fourths of the town did nothing else but set up trade unions?" (Ibid., p. 6).

In fact, the situation was neither so bad nor so good. The majority of Warsaw's population did not take part in establishing independent trade unions (even though they did support them). Similarly, it is not true that the state's institutions remained passive and did not try to foil the movement (even though they did not stage spectacular crackdowns). The most important factor in building independent organisations was that mutual distrust which was rife in the early stages of the turbulent process was swiftly overcome and replaced by organic social bonds among people of various backgrounds, occupations, attitudes and mindsets.

The quoted report contains a few other elements typical of the formation of independent organisations. Firstly, there certainly were barriers to new forms of social activity. One of them was a deeply entrenched fear: people were afraid of reprisals and the almighty control apparatus; they also dreaded spontaneous, uncontrolled action. The other barrier, which in fact enhanced fear, was that a sense of social bonding was sorely missing while divisions yawned between

39 This emphatically illustrates the fallibility of human memory, because, while some people might already have formed an idea of a mass, nationwide trade union by $4^{\text {th }}$ September, the concept of a trade union called Solidarity was certainly not in the cards yet. This idea germinated when delegates from all over Poland met at Gdansk's MKZ (Międzyzakładowy Komitet Założycielski, i.e. the Inter-Enterprise Founding Committee) on $19^{\text {th }}$ September 1980 . That notion had been developing gradually until Karol Modzelewski came up with a suggestion to combine the existing regional Founding Committees into one Independent Self-Governing Trade Union "Solidarity," according to the "Information on the development of the independent trade-union movement" No. 2 of $18^{\text {th }}$ September 1980. 
individuals, vocational groups, factories, communities and even workers' groups within one organisation. Building an independent, self-governing union above all required overcoming objective and emotional obstacles. The former were caused, for example, by a lack of "public" communication channels, while the latter were brought about by multiple negative stereotypes and mutual prejudices fuelled by the way social life was organised.

Secondly, the above-cited report implies that the great social process, dubbed "renewal" by the official propaganda, followed two trajectories. One of them was charted by self-organisation efforts which were undertaken by workers of big industrial plants, while the other was mapped by the capital city's intellectuals emphatically, intellectuals rather than the traditional intelligentsia, as research and academic institutions were predominantly hubs of social action and, from the very beginning, sought to attract some intelligentsia groups (primarily teachers).

The nine-letter union, whose name echoed the official employment structure (science, technics and education), assembled several thousand people and developed less robustly than the Mazovia. Importantly, both the Mazovia (still as a regional organisation rather than as part of Solidarity) and the NSZZ PNTiO were grassroots organisations that embraced similar values, thought of the social situation in similar terms and pursued similar goals.

The slightly comic initial misunderstandings could result from different early assessments of the situation. The intellectuals had a very clear awareness of the social situation, had closer links to the independent democratic opposition and/or were directly involved with the independent democratic movement institutions (such as socio-political associations, samizdat publishers, the Society for Educational Courses, etc.). As such, they may have been more hopeful about the progress of the social movement and less preoccupied with possible obstacles than workers-activists.

The intellectuals were more realistic in their assessment of the workers' protest and self-organising than the engaged leaders of the workers' community. As a matter of fact, direct experience corroborated the workers' less optimistic appraisal of the situation as operations aimed at thwarting the rise of independent trade unions targeted predominantly industrial plants.

The swift growth of the NSZZ PNTiO was halted when the nationwide trade union Solidarity was established. The nine-letter union's activists in attendance at the second general convention in November 1980 resolved to disband the organisation and join Solidarity. The process was certainly complex, controversial and fraught with passionate disputes. The $2^{\text {nd }}$ General Convention of the NSZZ PNTiO Delegates itself, the preceding campaign in which the union's 
units developed their own instructions for the delegates and, likewise, the very procedure of incorporation into Solidarity, all added up to an invaluable lesson in democratic institutional practices, despite many non-democratic group behaviours and ventures. We shall later focus on understanding what "democracy" means and defining "democracy" in fixed terms immune to vicissitudes of interests. Such considerations were all the more important as the communist regime often spoke of "democracy," but used the word with an array of adjectives, among which "socialist" was invariably reiterated. In contrast, the catchword "democracy" without any modifiers was evoked from the very onset of the independent trade-union movement.

The relations between workers' and intelligentsia's communities were essential to the development of the social movement which produced Solidarity. Admittedly, the trade unions of Warsaw's intellectuals and Warsaw's big-industry workers developed separately at the beginning, but this did not mean isolation or incompatibility. Controversies, which seem to have been inevitable at least in the early days, did not set the pace or rhythm of work and social consciousness. Even if organisationally autonomous, both movements were, in practice, uniform as they grew out of similar experiences and reflections, embraced the same ethos and pursued the same goals. This is illustrated by the nine-letter union's consistent involvement in Solidarity's actions (e.g. a token strike on $3^{\text {rd }}$ October, drafting laws to be implemented after the Gdansk accord, protests against the refusal to register Solidarity, etc.) and by the massive engagement of the NSZZ PNTiO members in organising Solidarity (first at consultation points and then in the Mazovia Bureau).

The two trajectories of the trade-union movement in industrial plants and science institutions, respectively, can also be interpreted as bespeaking controversies around the model of independent trade unions in Poland. The controversies surfaced not only in that there were separate trade-union organisations but also in how Solidarity developed as a societal institution. The basic question was whether the independent trade-union movement should take the form of one uniform, nationwide organisation or, rather, of several self-governing, nationwide organisations for respective occupational groups (conceived outside the bureaucratic notion of industries, or "branches," as defined by the state), which could form alliances or confederations. This raised further queries. One of them was whether the new trade union should express interests of occupational groups, or whether it should aim higher and modernise the entire social system. This dilemma was to become particularly pertinent soon.

Such uncertainties were associated, on the one hand, with the negative experience of the CRZZ, a highly bureaucratised "mammoth of an organisation" and, 
on the other, with the symbolic meaning invested in the workers' protest on the Coast and in the agreement with the party-and-state authorities. The point was that the victorious protest not only paved the way for new modes of expressing workers' interests but, essentially, symbolised and heralded a more general change in the social order. It restored the notion of "the citizen" its proper meaning.

Eventually, the fusion of the two independent organisations into one regional organisation of Mazovia, which was itself part of the nationwide Solidarity unionist movement, betokened the rise of a model where the trade union expressed multiple occupational interests and, besides, was a fulcrum of reform in society and the state.

\section{The Formation of the Social Movement}

\section{The Summer of Revolt and Protest}

The formation of the independent trade union, its principles and organisational structure is only a fragment of a longer and more momentous historical narrative. What I mean by this is the development of a huge social movement that found its "material," institutional manifestation in the trade union. This narrative tells how a certain form of social consciousness developed, how a certain spiritual and interactive community arose, and how a system of emotions and reasons evolved into maturity, all of which added up to a definition of the social situation that called for action. As a matter of fact, this should be put even more straightforwardly: people who had such a definition of the situation could not possibly fail to undertake action for which it called. The summer of 1980 in Poland "capped" the realisation that change was necessary, a realisation which was by no means a new one. In the interviews, our respondents regularly rehashed a simple idea that could indeed serve as the slogan of the day: "It can't go on like this anymore!" The words got a veritably symbolic ring, conveying the relevance of the accumulating social experience. "These conversations," one female respondent admitted, "were the same as everywhere else [...], low spirits, irritation, the sense that things could no longer go the way they had, that something must change [...]" (S 22, p. 3). "We were off the night shift 'cause we had a special night commission, so we were off the night shift and didn't go back to work. Later, a friend of mine told me that she'd talked with other workers, and that we wouldn't go back to work; simply that mess couldn't be allowed to continue" (S 39, p. 2). "It'd have been against my conscience to do something like that, to condemn a person, people, a group of people who put up a protest, even though we were told they were hooligans and irresponsible louts [...], it was a 
genuine class revolt, with people pushed to the wall [...]. The strike was a necessity. [...] you could say that they'd been luring people with a sausage stuck under their noses and then snatched the sausage away. And enough was enough" (S 66, pp. 1, 2, 12). "People talked a lot, for they simply hadn't been allowed to speak out loud $[\ldots]$. So you got to hear [...] that they only summoned us to work, but we got nothing out of it" (AS 67, p. 1). "In the early days, people [...] were purely emotional about things having to change, about things finally being taken care of and that it might be for the better. We didn't know yet why it might be for the better and who was supposed to make sure it'd be for the better. Anyway, there was simply this feeling that something must finally change in the country" (S 64, pp. 7-8). "It isn't just about monies, after all, it's about the cause; what's important is that it's about this drive towards something new simply [...]" (S 43, p. 3).

The belief that things had to change in Poland was articulated with ultimate clarity during the strike in Gdansk. Therefore, the signing of the accords triggered a snowballing constructive social action. Yet the full-fledged action of establishing new social organisations (i.e. independent trade unions) was preceded by another action involving spontaneous resistance and manifestations of discontent. This preceding stage brought about a wave of disconnected strikes in the summer of 1980. Some of the strikes did not even involve entire factories. The strikers' demands basically did not go beyond financial and subsistence issues. Importantly, however, individual strikes in the Warsaw region were held with greater resolve than any previous protests. At the same time, information kept coming in about strikes organised all over Poland. The protests surged so ubiquitously that the news about them spread despite the government's effort to curb the strikes themselves and to suppress information about them. The regime's obstruction of information was first dismantled by the mass protest of factories in Lublin. The news about strikes undoubtedly fostered further protests. The strikes as a rule ended rather quickly when pay-rise demands were met. At the same time, the strikes were too numerous and widespread for the government to proceed to reprisals after "putting down the fire" at individual locations. In all probability, the government was, in fact, not very eager to launch large-scale reprisals on that occasion since not only ordinary PUWP members but also lower-ranking Party functionaries were inclined to acknowledge, partly at least, the reasons behind strikes.

Nearly all participants, in particular the active organisers of strike actions, point out that, in the aftermath of the victory, the belief soared that the victory had only been illusory and that altogether different claims should have been made. Discontent did not disappear, even though the financial demands had been fulfilled. This feeling promoted the birth of a new consciousness by generating 
a problematic situation that called for a solution, reflection and discussion with others. In this way, the summer strikes contributed to a new atmosphere, as they directly produced a new network of social contacts and a powerful sense of social bonding. At the same time, negative experiences accrued in many enterprises; it repeatedly turned out that wherever social bonding and solidarity in protests had been missing, all those involved had been on the losing side. This raised the consciousness of the supreme idea which served as the name and the catchword of the Independent Self-Governing Trade Union "Solidarity."

The strikes re-configured the elites of workforces as the protest actions conferred a moral authority on their organisers, who did not cave in to fears and succeeded in getting others engaged. A specific, albeit incomplete, understanding of the reasons behind the victory also evolved. For no matter how spontaneous the strikes in the Warsaw region over the summer of 1980 might have been, they were all consistently based on a set of principles. Symptomatically, our respondents from the FSO, Ursus, Róża Luksemburg, ${ }^{40}$ the Milanówek silk plant and MZK report that exuberant and spontaneous behaviours were combined with an unusually rational strategy of action. The strategy was an outcome of the already conceptually organised social experience associated with staging strike actions. This did not perhaps involve a "particularist" consciousness, so to speak, but was certainly linked to the direct prior experience of protest actions. Even in the enterprises that had their own history of striking (such as the FSO, Ursus and the MZK), people drew not so much on the direct knowledge of former participants and organisers as rather on widely disseminated, generalised historical knowledge. Nowhere did strike activists stem from the groups that had arranged and managed earlier protests. Strikes were organised so as to minimise the risk of reprisals and to prevent the government's manipulations and provocations. Decision-making was informed by the well-entrenched recognition that rational conduct was exigent. This recognition was in turn founded on the realisation that the protesters and the Party and government functionaries had widely different interests. Consequently, people saw the situation in terms of fighting for their rights and believed that the government, with all its alluring declarations and promises, must not be trusted.

\section{Warsaw on Strike: The Summer of 1980}

Actually, three waves of protests can be distinguished, with the first surging in early July, the second coinciding with mass strikes in the Coast region (mid-August)

40 The Rosa Luxemburg Electric Lamp Factory. (translator's note) 
and the third involving either planned or actually launched solidarity strikes in sympathy with the Coast strikers (late August 1980). The first two instalments were similar. The strikes vented discontent growing of late and evinced the formation of a negative definition of the social situation, which called for an open protest. At the same time, the strike experience bred a new consciousness of and a comprehensive reflection on social issues. This stage culminated in the signing of the agreements in the Coast region.

The third wave of (solidarity) strikes was a bit different. The protests grew from the recognition what the social discontent actually meant and what goals and values were focal to the struggle. Such a solidarity strike was launched in the Warsaw Steel Plant. The strike was also symbolic, with the Warsaw Steel Plant striking, so to speak, on behalf of other workers of the capital.

The simplest typology of strikes is based on how and by whom they were organised, i.e. on whether a strike was spontaneous and, as such, represented an emotional revolt or whether it was well prepared by a group of people.

This question is important for a few reasons. Firstly, the official propaganda presented the strikes preceding the signing of the accord as stirred by anti-socialists forces in an attempt to use workers' disgruntlement for their own agenda. In this propagandist portrayal, the movement of protesting workers was painted as an elaborately orchestrated and centrally masterminded strike "action." The strike wave was treated as a meticulously designed plot against the government, following a prior script and deliberately launched by a mysterious and cynical brain-trust bent on exploiting simple people's social discontent for its own secret purposes. Secondly, and more importantly for our argument, such a conspiracy notion of history surfaces in our interviews. In this perspective, the strikes were part of a campaign planned down to the tiniest detail and had been, in each case, carefully prepared in advance. Such ideas appear, for example, in the following interview excerpt: "At four I got the message, by five I'd already reached the workplace, and talks started, but to little effect since nobody went to work that day [...]. You talked with the majority of the workforce. The workforces never agreed to talk in smaller groups. [Interviewer: 'Why?']. I don't know [smiles slyly]. Today you could say that it was the fixed tactic. I had no idea of it back then, but I've been told since that it was a special strike instruction [...]. Some [people in the enterprise] went on strike spontaneously, but others had been prepped and knew the instruction. Later, I asked that question and was answered that it'd been in the works since 1976 [...]. That's how things must always be, from general to specific. A general outline must be given, and then details are only filled in. Somebody orchestrated it all [...]" (D 73, p. 2). The respondent goes on to describe representatives of the workers on strike: "Some 
of them were truly respectable people, and others had nothing good to show for themselves. They were people whod only worked briefly. I suppose they must have been trained since 1976 and then sent off to various enterprises" (Ibid., p. 4).

Asked whether people who had been active during the strikes later joined the Founding Committee of Independent Self-Governing Trade Unions, the respondent answers: "You need to look at it differently. There were two groups: those who climbed up the bars and made sure that people didn't leave [while the strike was in progress] and those who compiled and put down the demands - spokespeople for the workers, so to speak. And those spokespeople joined the founding committees, while those at the boom-gates, I mean those well-trained sentries, didn't, for they'd already done their job" (Ibid., p. 6).

Another respondent subscribing to the conspiracy theory of history says: "I'd never have thought anything like that [protests and the establishment of independent trade unions] could ever happen. It seems this movement is an exceptional case, and I believe it must have been hatched since long ago, and the attempt to change prices was an excuse, I guess; because something that came up like that must have been devised, undoubtedly [...]. I'm completely sure that it was a bottom-up thing. I mean, the protest in Gdansk seemed natural to me, but the programming of the entire and the organisation of that whole strike and the entire...team that ran it later, that had been prepared in advance. [...] They knew that those people weren't supposed to go out of the shipyard, because it'd be very difficult to control. It'd have taken just one person saying 'We're going out of the gate,' and no force would have been enough to control the situation. And this is where those organisers had simply anticipated that and arranged it so that the movement, those workers, those engineers, all those people who worked there simply stuck to their work-stations and didn't take to the streets. And this is what, I believe, is only possible if you think of it in advance. It can't be otherwise. [Interviewer: 'Right, but perhaps the workers thought of it in advance themselves?']. Nope. It's very rare. I was a worker, too [...], when things happened in 1956, and I must tell you that when people respond to evil, there is always some brutality to it [...] in such moments reason is hard to find. Only people with experience, people who have experienced time and again and who are managed by someone can self-organise in such a movement as that in Gdansk" (D 8, p. 1). The respondent addresses the details of this organisation: "But I must say that even at [our] enterprise, when the strike was being organised, there were well prepped people around. For example, people from the University who did manual labour - there're a few of those who were organisers, so one can expect the entire organisation was thoroughly pre-programmed, and you have no doubt, surely, that it was very neat. Very efficient." (Ibid., p. 14). 
Quoted at length, the passages reveal the logic of conspiracy in thinking about social processes. Organised social actions are construed in bureaucratic terms. Rational and orderly action involving many individuals is believed to be a matter of coordination, as is the case in bureaucratic institutions. Bureaucratic organising is based on hierarchical relationships and distribution of welldefined tasks. As a result, there are always top and bottom levels, with coordination resulting from top-down orders and prohibitions, i.e. "instructions" issued for those at the lowest rungs. The instructions are detailed and very concrete, and although people appointed to implement them do not have the full picture of the action plan designed at the top, their position in the "reporting lines" obligates them to follow the instructions unfailingly. As a consequence, all actions are coherently channelled to achieve presupposed targets. It is beyond "a bureaucrat's" imagination that people can act in different ways and that there are different mechanisms promoting rational and concerted action. Advocates of the conspiracy version of history believe that there must be an obedience-inspiring "figure of authority," capable of swaying people to follow his/her instructions. Our conspiracy champions, unfortunately, do not specify in what way the "strike organisers" enforced obedience. In some interviews additional details are given to complete the picture: "Those organisers threatened people, applied moral pressure, blackmailed and even used force to make people join the 'action.' In the afternoon, drivers started to refuse to work these routes, explaining, well, that there were people hanging around at the stops and threatening, intimidating them, saying you've no right to ride here $[\ldots]$, and don't spoil our cause $[\ldots]$. They were simply civilians who, sometimes by soft persuasion and sometimes by threats, beating, just like that, chased those drivers away from the routes serviced by the Pożarowo company. And so, on the following days, the stoppages were longer and $[\ldots]$ drivers from other companies refused to go out" (P 48, pp. 3-4).

Our respondents talk in similar terms about joining Solidarity: "There was, it must be said clearly, a huge moral pressure, browbeating of sorts: 'C'mon, aren't you going to join, really?'” (P 32, p. 10).

In the bureaucratic framework, individual actions are coordinated by exacting discipline in task performance. The disobedient are punished. Given this, the strike organisers must necessarily have relied on repressive measures.

Another typically bureaucratic thing is that specialist tasks require competence and training. Hence, the cited interviews highlight the organisers' competence and expertise as well as lengthy preparations in which people were purportedly primed to perform particular tasks during the strike. Strike organisation is thus viewed as a product crafted by a group of human management savvies. 
Another important assumption is that the top and the bottom of the hierarchy differ not only in terms of their roles but also in terms of their awareness and interests. Those in charge who organise the strike use people's discontent for their own purposes. This is where "conspiracy" thinking is at its fullest. If one leads a social movement, one is in charge of it. And one is in charge of it not to accomplish the common goals of the movement, but to achieve one's own purposes, which nearly by default cannot overlap with the aims that fuel the human "mass" involved in action. Collective action of sizeable human groups is framed in terms of black-and-white binaries: either it is spontaneous (i.e. triggered by emotions and not organised) or it is engineered by a handful of experts (who have their hidden agendas, to accomplish which they craft a bureaucratic organisation out of the "mass" before action proper is commenced). On this model, a collective of many individuals cannot act rationally and effectively unless controlled by this or that power.

The relationship between the conspiracy-underpinned interpretation of the workers' protest in the summer of 1980 and the bureaucratic take on social actions is corroborated by the fact that conspiracy-slanted views are most commonly voiced by the directors and the heads of the old trade unions' Enterprise Councils. They are rarer and less pronounced in interviews with the enterprise-level PUWP secretaries. Though occasionally evoking conspiracy, the Party secretaries generally are quite firm about both the strikes and the rise of independent trade unions being manifestations of a spontaneous social process. They realise that social actions are driven by various mechanisms and do not have to emulate bureaucratic models.

This is how a PUWP secretary describes the same strike that was exposed as a scheming plot by the director quoted above: "It seems to me that, at the very beginning, that stoppage wasn't prepared in any way, initially no demands were formulated, and only later during the standstill, only then [...] did the drivers and motormen, pencils in their hands, got round to calculating; and vis-à-vis them the company's management [...]; simply on that day, on $11^{\text {th }}$ September, they were not prepared enough to immediately come up with particular demands, particular claims. Only as they started to look about themselves did it occur to them that there were options, and so it grew slowly" (P 48, p. 6). "Simply, out of that group that stopped cars from going out, well, no leader group emerged to negotiate with. Only at around nine o'clock a, let's say, a committee, a group started forming that began to kind of take charge of that whole stopping of traffic, and then they were all invited to the common room and negotiations took off $[\ldots]$. And on the following days, the stoppages expanded, and drivers from other companies also refused to go out [...]. Anyway, on the following days, you 
could see they were organised better, and someone'd taken charge of things 'cause if bus and tram services stopped, they stopped so that whole boroughs had no transport" (Ibid., pp. 2-4). The enterprise PUWP secretary notices that a form of organisation emerges incrementally from spontaneous social activity.

Finally, the upholders of the conspiracy theory of history offer a specific interpretation of the reasons why the strikes erupted. The choice of "erupted" is in itself illuminating. The motives behind the collective protests are viewed as defined, substantive stimuli, as "pulling the trigger," so to speak. We already know that the cause "proper" is the activity of a conspiring group. The group, eager and ready to act, waits for a suitable moment. This moment comes when discontent erupts. Common people's disgruntlement always arises from feelings, such as revolt or anger. There is a stimulus that makes them feel in jeopardy. Most of the interviewed directors and Enterprise Council heads identified people's living conditions as the direct cause of their dissatisfaction. As implied by the interviews, in some enterprises the strikes were provoked by raising meat prices to the level of what was then referred to as "commercial" prices (the price increase was announced in July and was later revoked). When people calculated how much they would have to spend on meat, they rebelled and went on strike. At that moment, the conspiring organisers supposedly stepped in to use this expression of discontent for their own purposes.

However, there are tiny, albeit extraordinarily relevant, details to the July protests which complicate this clear-cut picture. Alongside the increased meat prices, the price of packagings in which meat was sold at factory shops was also raised fourfold.

As observed by a respondent who was HR deputy director at the time, this seemed to infuriate people far more than the rocketing meat prices themselves. However, her interpretation of the fact sounds rather unconvincing (cf. D 14, p. 1pass.).

It does not come as a surprise though, given that her view of people's motivations is reductively mechanical, and that she primarily comprehends human action as a response to a stimulus. The conspiracy-driven account ignores the dynamics of people's thinking along with the growth of their social experience, which encouraged their reflection and prompted them to develop a shared definition of the situation.

What sense people made of the stimuli "administered" by the government in the summer of 1980 no longer depended on the government; instead, it came to depend on the social consciousness which had long been growing and expanding. The strikes were brought about by the development of people's thinking and the dynamics of the group definition of the social situation. 
The drastic rise of the price of plastic bags in which meat was sold seems to have been so outrageous to workers that it was erected into a symbol. This indicates that a consciousness must have developed by then in which that fact was ascribed a motivating power. An apparently trifling event came to symbolise the government's slighting of people and belittling them as children who would not notice additional exploitation.

Our team wanted to establish why, throughout Poland's post-war history, meat price rises, no matter their economic justifications, had invariably triggered collective protests only to eventually engender a mass-scale revolt. Our answer was that meat price increases implied that the government ignored people's attitudes, needs and interests. This reading of price rises had been forged and perpetuated in and by historical experience. The first centrally-decided and substantial meat price rise took place in 1953 . While meat prices were raised, the prices of production inputs and big machinery (engines, rail tracks, ships, etc.) were lowered. The Stalinist propaganda proclaimed that move to be another splendid triumph bringing Poland closer to the socialist prosperity of the working people. This stirred considerable commotion in many enterprises, and several people who openly denounced the outrage became targets of harassment. Symptomatically, few people today remember those circumstances, even though all subsequent meat price rises bore the same connotations as in 1953. These meanings became fully recognisable and were discursively articulated only in 1980. For, of course, if people in Warsaw went on strike, it was not because the price of meat packaging increased from two to eight zloty, but because people viewed the rise as an attack on their dignity. Therefore, if the increase in meat and packaging prices caused the Warsaw strikes in July 1980, it was not because meat mattered so much to working people in Poland, but because the rise had already acquired a definite symbolic meaning and consenting to it would discredit workers in their own eyes.

One of the PUWP secretaries insightfully depicts this knotted nexus of factors: "I personally think that this was the mounting up of, I'd say, the discontent of the working class, including I guess entire society, because of, among other things, or as a result of not meeting the requests and, additionally, well, so to speak, that funny pretending that nobody had the slightest clue about requests or demands to be met; this is one thing. Another thing, I believe, the decisive factor was the price rise announced by the prime minister without society's preliminary approval, and, generally speaking, what finished it off, I guess, was what the former leaders of the government and the Party said who, well...focused on trifles and believed that, perhaps, if they threatened society in their speeches, all this would be prevented. [...]. Factory $\mathrm{X}$ went on strike after a meeting at the 
Central Committee about the assessment of the country's economic situation, where they talked a lot about, with comrade Edward Gierek, a former first secretary at the time, obviously presiding, where they talked about the development of agriculture, and started saying that rains, cloudbursts and exceptionally bad weather conditions would make us nearly starve" (P 9, p. 2). These words aptly indicate a tangled mesh of meanings associated with the meat price rise which was the direct impulse for strikes.

Besides the meat price rise, there was certainly one more reason behind the summer strikes in 1980. In spring and early summer, wage scales were changed: wages were ostensibly raised, but at the same time production targets were altered, which resulted in lowering rather than increasing incomes relative to actual workloads. In several enterprises, workers did not grasp immediately what ramifications the purported improvements would have. It was in the summer of 1980 that the new wage scales and production targets came into effect. The moment that workers realised they had been deceived coincided with the meat price rise, aggravating shortages on the consumer goods market and fuelling protests across the country. The strikes in Lublin were of particular relevance to Warsaw. Tolerably accurate information about their scale and intensity provided a model for other protests until, obviously, the mass strike in the Coast region absorbed everybody's attention.

Back to the depiction of the summer strikes in Warsaw. None of them (at least in the enterprises we researched) was organised the way that the advocates of the conspiracy interpretation of social events imagine them to have been.

This is how the actors themselves describe them: "And, you see, I rushed to the plumbers and was urging them to go on strike. Then off, to the electricians, and I got them all in one room. So we decided, and it was $2^{\text {nd }}$ July, how to do it. I mean, to go over to the CHP, stand by the boilers and stay put. And as we said, we went over and stood there. Others started to join us: 'What're you doing?' 'We're on strike.' But many people were a bit scared. Z. rushed in and asks: 'What's going on?' 'We're on strike.' That is, by the time he came over from the plant, I'd already made this strike. The manager came over, but he didn't want to talk with us, only with the foremen. So I say: 'Sir, if you wanna talk, talk with everybody. We're on strike.' He went pale. Everybody was scared. One foreman [...] was so nervous he had a seizure. It was a risky business after all. No one knew how things would pan out. We decided to go to the gaffers' room and sit in there. And to demand that the management come over. We put down first demands quickly. There were three: pay rise by one scale-level for all, more danger money for all, and a highprice allowance or something like that. I don't even remember it exactly [...]. [Interviewer: 'Did anybody else go on strike on Monday?'] They did. Three other 
departments did. And, in fact, we'd already worked out a plan of shutting the heat plant down $[\ldots]$. There'd already been a memo dispatched to the forge boss to work all the material already in the furnaces so it didn't go to waste and not to put out any new material. Otherwise, the management would be accountable for the losses. So things were under control. Fourteen hours: the phone rings, they tell us not to shut down, and that the director and the management are coming over in fifteen minutes" (interview J; S, pp. 6-7).

This is how the same strike is related by the factory's PUWP secretary: "Since $1^{\text {st }}$ July, we'd been preparing the implementation of a new wage system for the steel sector $[. .$.$] and because that sector had been receiving pay rises since 1^{\text {st }} J u l y$, while other sectors hadn't, rather heated discussions started [...]. It was quite clear that the prevailing attitude was that of making claims, of demanding wage regulations for the other departments as well. This coincided with the decision to increase prices of meat products and caused strikes or - as the phrase went back then - downtimes [...], all this didn't have any organised form then, the strikes, well, somehow occurred spontaneously. [Interviewer: 'Do you remember the representatives?']. They were not any selected group; they were simply representatives of a wide collective who spontaneously went to the meeting with the management. [Interviewer: 'But who were they? Do you remember those people now?']. As a matter of fact I do [...]. For example, at the CHP [...] a group formed who $[\ldots]$ put forward certain claims $[\ldots]$ in a systematic $[. .$.$] way" (P 44,$ pp. 2-3).

"It's not that one person stands up, right?, and says: 'we'll go on strike, right? There's a problem, an issue, so people come together and talk. First, it is, and it goes without saying, all about anger, right?, and later people think on what to do next, right? What we can do and how. Say, we've tried to reason with the foreman or the manager in this or that way. He throws up his hands and says that this or that can't be done. Or the cases when people are told they're wrong. This is what especially drives people mad. And then there's the question, right, what are we supposed to do in such a situation? Well, the only form of protest is to stop working" (a rank-and-file PUWP member, P 13, p. 3).

Another person recounts the same strike: "First they gave us a pay rise and then said we had to produce 250 pieces more [...]. So what kind of a rise is it, if I have my workload increased and have to do much more? [...]. I knew more or less what was going on 'cause the previous day a friend of mine'd mentioned we'd refuse to work, for that rise was unfairly distributed. When I went down, I found out what it was all about. [...]. [It was] the morning shift. We were off the night shift 'cause we had a special night commission, so we were off the night shift and didn't go back to work [...]. We went to have some tea, coffee in fact, 
not to fall asleep [...] there's a canteen in that department, there's a cooker and gas supply. Later, a friend of mine told me that she'd talked with other workers and that we wouldn't go back to work; simply that mess couldn't be allowed to continue [...] more pieces to produce, the workload increased [...], it's no pay rise [...]. Supplies are poor, and we came out about it. Later, around seven, the director came over, later ladies from the Factory Council came over and said: 'Go back to work, roll up your sleeves'[...]. And later the factory secretary came over, too [...]. He goes: 'Get down to work, get down to work.' We say that we're paid too little, that we demand a bigger rise [...]. After twenty years in the job, we'll get the least of it. And he replies: 'That's because the world's a funny place.' So I ask him: 'Why is the world a funny place?' 'Because there're too many people in wrong positions.' [...]. [Interviewer: 'The director came in and was very uppish towards you; how did you respond?']. We say: 'Wait a moment, we're not going back to work, listen to us, please.' He replies: 'Back to work, back to work, right now!' We say: 'We're no workhorses, we can go back to our jobs, but listen to us first, please.' Later we got a reply in writing [...] that the production targets would be reduced" (S 39, pp. 1-3).

Here are other reports: "The July strike was, it was basically differently made than the later ones, possibly because it was the first one, still before the Coast strike. And it was [...] so impetuous [...]. It all started in the toolroom. And this is almost a rule 'cause it's a shop with old workers, with little staff turnover. The people've been there for long, know each other very well, so they're automatically more solidary in action than others [...], they're simply in sync, so it's easier for them to make certain claims and to have a uniform view on these claims [...]. Of course, we got to hear about the reasons why they'd [the toolroom workers] stopped working, they only had pay demands then [...]. The other departments mustered their courage at that moment, for the toolroom had already stopped and, one by one, practically on the same day, almost the whole [factory] came to a standstill [...]. At that moment, there was no, it must be admitted, there was no agreement among the departments when the strike started. Only later, as the strike went on, opinions were shared and claims, too [Interviewer: 'Who had made up the group that initiated the strike?']. So there was a little problem with that. Officially, such groups were not formed. And that was because there was a fear of reprisals against particular people, and it was well founded. [...] there were claims made by the whole group from the department, that is, by all the workers elected at that moment. [...] But there was a spontaneity about it, and that spontaneity was there also in other factories. Only, let's say, Gdansk had a programme of sorts, and it was later implemented in the strikes [...] When the strike was beginning, there was not time to put up a programme [...]. There 
was only this unanimity that the lists of demands overlapped in all departments "cause indeed the problems were the same everywhere" (S 20, pp. 1-3). So, there were situations in which the strike was initiated by one, known group, but there were also cases in which spontaneously brought-together workers elected a group of their representatives.

"Yes, $10^{\text {th }}, 13^{\text {th }}$ August $[\ldots]$, it was already after the Lublin thing, so there was a mood around that something can be done. What did the strike look like? Well, two, three people say: 'We're not going out.' And others go: 'So what are we doing?' 'We're not going out, we're staying put.' So we're staying put, the group is growing, no buses drive out - they're blocked, and people basically stop, not knowing what for. When the crowd had already gathered, they go: 'What are we stopping for?' 'Well, 'cause we're collecting demands.' 'What demands?' 'Money' [...]. And when Brzostek ${ }^{41}$ came over and asked 'What are you doing it for?' People said 'For money.' So Brzostek goes: 'I'll give you the money' But see what turns out then? It's not enough [...]. 'Cause those people were disgruntled not because they had no money, but because they remembered all the past vices of the management [...]. So money was that first main trigger. But then it turned out money wasn't the point at all [...] - the money crap was even cut completely" (S 36, pp. 2-5).

These passages vividly show how a strike "is made." Like any collective action, a strike is indeed organised, but it is organised differently than the upholders of the conspiracy-underpinned bureaucratic interpretation envisage it to be.

All our respondents talk of people who are faced with a problematic situation in which conditions change, directly affecting individuals as members of a collective. Any change in living conditions demands responding to the new situation - "something" must be done about it. This sets off the process of negotiating positions with other people involved in the same situation. As a result, a common definition of the situation is developed and incisively impacts people, determining the range of actions to be undertaken in the new social conjuncture. The definition of the situation is confronted with the previous state of affairs and with people's desires, because as the situation changes an active reaction is required. Consequently, people must answer the dramatic question of "what to do now?" If there are available action models suited to their particular problem situation, or if rational ideas and agendas come up, the collective's joint action develops at a staggering pace.

41 Jerzy Brzostek, Deputy Mayor of Warsaw. (translator’s note) 
This was exactly what the studied strike situation looked like. People were ready for it, because they shared a negative definition of the social situation. When protests start to pop up and/or people come forward and make a clear, well-founded case for a strike action, a decision is made which, though individual, is underpinned by the shared image of reality. The decision concerns a particular collective action, which initiates the next stage of social negotiations of, so to speak, technical nature. The objectives of the action must be discussed alongside the ways of expressing the "collective will," which is exhibited in multiple individual decisions to join the strike. The addressee of the claims (and thus the opponent whom the action targets) must be defined. The rules of in-group cooperation must be developed and, consequently, tasks must be distributed: somebody must contact the management, somebody else must put down the demands, still another person must secure the machines, etc. Collectively negotiated, the role allocation results from individual motivations to engage in tasks at hand as well as from collective expectations towards particular people. In this way, the collective evolves into a community of collaborating individuals.

Cooperation is spontaneous, while the joint action is emotionally loaded but also opens up new vistas of reflection. As such, it requires ongoing communication and deliberation. It is a spontaneous process of thinking together. Acting together is, at the same time, a continual discussion. This is where the rationality and coordination come from. In the discussion, practical effects of individual actions are worked through, and the collective feelings are made sense of and channelled. Spontaneity and impulsiveness intrinsic to such action neither contradict nor preclude rational organisation, if organisation is taken to mean the social process of negotiation and mutual adjustment of individual acts.

\section{The Factors behind Collective Protests}

Sociologically speaking, a few types of strike situations can be distinguished based on the degree to which workers are prepared to launch common action. Common action involves three major elements:

1) the definition of the social situation which sways people to act, determines the objectives of action and informs the programme of protest;

2) the sense of social bonding within and without the workplace;

3) informal leaders who are trusted and ready to act as organisers and spokespersons for the protesting workforce.

As the third factor is perhaps easiest to describe, let us start from it. 


\section{The Discontented-and-Defiant}

There are three basic models of informal leadership.

1. There are informal bonds among opinion leaders and generally trusted spokespeople for the workers' interests. In such circumstances, people respected by the workforce know each other and are in close, friendly relations with each other. Befriended, they share the same consciousness, beliefs and values, express them publicly and pursue common goals. At the same time, members of such groups know that they are trusted by their co-workers, whose attitudes and interests (both social and work-related) they assert. Such groups tend to "seal themselves off" in fear of reprisals because, when meeting up, they discuss political and social issues in ways which, obviously, stray from the Party and state orthodoxy.

The discontented-and-defiant were noticed not only by those whose interests and beliefs they had the courage to vocally articulate, but also by the directors and the PUWP secretaries. A respondent speaks of the attempts to get rid of informal leaders: "Attempts were made to fire us. We never drank any alcohol at work. When going out, we always searched our pockets and bags for things they might have planted on us. At a name-day event, ${ }^{42}$ it was in March, I and Z. betted on when the entire management would turn up to see the mercury room, for a mercury room was just being built [at the respondent's factory]. Half one and the whole management walk in, as if casually: 'We've come to see how the mercury room's going.' And, in fact, they came to see if we're offering and drinking vodka. They were just looking for an excuse to fire us" (interview J, pp. 10-11).

The factory's PUWP secretary describes the same people in the following way: "For example, in the CHP a group formed, I mean set itself up, which was the most active of all, and they made certain claims in a methodical way, so to speak, and one of its organisers is now an activist in the new trade unions. [...] whenever I met them, I must say, I could feel that they had a huge grudge both against the management of our factory and against our state authorities about the way things were going. Those people talked about simple, but also wide-ranging problems which might have been addressed here and there, but were still underappreciated" (P 44, p. 3).

42 The name-day, i.e. the feast of one's patron saint, was traditionally celebrated in Poland more conspicuously than the birthday. Putting up small name-day events for co-workers at the workplace during the working hours was a widespread custom, which notoriously involved consumption of alcoholic beverages. (translator's note) 
The conduct of that small group invested them with moral authority, and consequently they were viewed by their co-workers as possible future leaders. When such informal groups appear within an enterprise, they clearly influence the dynamics of striking: the pace accelerates, strike actions are more effective and more rational, precise goal-setting is facilitated, resolve in negotiations with the authorities is promoted, and resistance to their counter-measures is increased.

This predominantly happens because engaged, pro-active individuals keep in touch with each other and, instead of being anonymous, they are morally and intellectually prepared to take up roles assigned to them by the participants in collective action.

2. While there are informal leaders well known to the workers' community, enjoying their support and regarded as moral authority, they do not form a group as defined in sociology.

It means that, as a rule, they are not acquainted with each other, have no private contacts with each other, are not mutual friends and do not discuss things together, which precludes them sharing a group self-consciousness. Their social impact is limited either to particular departments of the enterprise or to a certain social circle (e.g. a relatively intimate group of colleagues, a shift crew, etc.). What this model and the previous one have in common is that informal leaders explicitly declare their views, and their attitudes are widely known, even though they may only be popular with a few workers.

How the attitudes of the discontented-and-defiant are manifested and in what public circumstances they win trust and support can beg an explanation. It turns out that the relevant opportunities were provided by $\mathrm{KSR}^{43}$ meetings and by numerous gatherings and rallies held by the old trade unions or Party agencies. Such occasions offered a forum for voicing criticisms and negative assessments of the management, the Enterprise Council and, even, the PUWP and the government. Such critiques were all the more meaningful as the mood of fear, torpor and helplessness was pervasive. Consequently, those who articulated them risked reprisals and inspired admiration and respect in their co-workers.

Such conduct and attitudes made the defiant natural candidates for leaders of collective action when workers started to stage protests. In such moments, they

43 KSR stands for the Konferencja Samorządu Robotniczego - the Conference of Workers' Self-Management. Instituted in 1958, KSRs in enterprises included members of the factory's PUWP unit, members of the factory's trade-union council and selected representatives of the workforce. (translator's note) 
tended to meet each other personally and quickly form a leadership group. If there were several well-known defiant people within an enterprise, the authorities could not manipulate the protesters easily, while chances improved that all workers would engage in the joint action and accomplish the strike objectives.

3. As the strike action progresses, it brings forth leaders and spokespeople for the collective interest.

This situation differed from the previous two models in that people who had earlier earned social recognition did not actually become leaders. Instead, as one respondent puts it, they were vested with tacit authority. They were reputed for their beliefs and/or organisational skills among their close friends, or they revealed their capacities when the collective decision to go on strike was made. Only the strike situation itself made them into leaders and champions of the collective will. This concerned first and foremost the enterprises where fear was particularly paralysing and could only be overcome as a result of the collective resolve to act.

This had significant consequences for the course of the strike action. Firstly, this happened during strikes initiated within particular departments or spatially and organisationally separate divisions, without extending onto the entire enterprise. Whether or not the example set by co-workers was stimulating, when leadership candidates were missing, negotiating common goals and bargaining on behalf of the enterprise's entire workforce were severely thwarted. Secondly, the community was only forged in and through the strike experience out of which social opinion leaders and moral authorities emerged. Thirdly, that helped the bureaucratic apparatus manipulate workers in order to sow divisions by meeting very limited demands which did not represent the workers' general interests.

\section{We: The Circles of Community}

Let us focus now on social bonding, i.e. the second major aspect of strike actions. Social bonding designates a sense of community - community of interests, beliefs and values. The "psychological" sense of community is an inner condition in which a person feels that $s /$ he is not alone and that others will not be indifferent to his/her fate, while s/he will not be indifferent to their fate. This feeling motivates the person to take up action when the perceived psychological affinity is corroborated in everyday life. This experience primarily involves direct contacts and interactions as prerequisites for joint action. Given this, what was said and done by the discontented-and-defiant, who had the courage to express their criticism, fostered the crystallisation of social bonds. Such 
people became living symbols of the community on whose behalf they spoke out (thereby clearly putting themselves on the line). Besides, taking personal risks to protect collective interests, they garnered trust since, while their views might not have been universally favoured, their intentions could not be doubted. The third situation (i.e. one in which social activists only came forth as social action progressed) was different. The activists were protected by the group, while their motivations "dissolved," so to speak, in the experience of the community. They had not been tested for strength and integrity before. This had ramifications for the entire group: the leaders were watched with an alert eye and a degree of distrust. At the same time, the likelihood of the leaders being set up by the authorities to manipulate social action increased. This is what indeed happened in some enterprises. Spontaneous leaders were used by the bureaucratic apparatus, for example, to meddle with the formation of independent trade unions by founding trade unions to which our respondents referred to as "directorial." The idea to set up such trade unions was often proposed by an experienced, usually PUWPaffiliated economic activist with ample practice within the old trade unions.

It can be posited that the course of strike actions, the efficiency of protests and their further relevance to the participants were correlated with the strength and extent of social bonding among the representatives of workers: the more developed the bonds, the more spontaneous the strike and the more determined and effective the protest.

The typology of strikes in the Warsaw-based enterprises includes two basic situations. In one of them, the strikes manifested the sense of social bonding and grew out of the workers' feeling of community. In the other, the strikes entailed building social bonds and turned the workers into a community. In the latter case, the early, initial bonds were very limited and tied only small groups, where closeness resulted from the simple fact of having long worked together. As such, they knew they shared the same beliefs and fought for the most elementary cause of equal consequence to everybody. Such groups often did not even extend across a company's organisational units; rather, they were separate work-teams, shift crews or, at best, departments.

Importantly, strikes that sprawled over entire enterprises were as a rule initiated by toolroom crews (or their equivalents). The frequency with which the toolroom is attributed the initiating and model-setting role in our data strongly suggests that it cannot be a coincidence. As our interviews imply, the toolroom is crucial to an industrial plant, forming, so to speak, the heart of industrial production and staying in touch with most other units of the plant. Central to technological processes (tool preparation), it usually assembles workers with expertise and experience. As such, the toolroom crew are certainly an elite in 
terms of occupational competence. At the same time, the toolroom is a setting which promotes the formation of the plant's social elite. Unlike assembly-line workers, the toolroom crew are, by default, regarded as inventive and self-reliant, perform individualised, specialist tasks and are personally accountable for their execution. They set the production rhythm themselves and are largely responsible for the final product.

All this requires greater mobility, both social and intellectual, and makes collaboration expedient. In the toolroom, one must consult one's co-workers and, often, advise and assist others. As a result, strong, informal bonds are forged.

As some of the interviews cited above indicate, other workers tend to view the toolroom crew as a closely-knit community which becomes a role model for others. When the toolroom goes on strike, it sets an example which mobilises other departments of the enterprise, no matter whether the workers orchestrate this spread deliberately or whether they contact each other only after the strike spontaneously ensues. At any rate, in our study, the spontaneous strikes in separate workplaces or departments as a rule merged into common action, and their organisers and leaders sought contact with each other, attempted to develop a shared definition of the situation and tried to establish the common rules and objectives of their struggle. In doing this, they followed the model provided by the toolroom.

The attempts to launch common action were not always successful. There were several adverse factors productive of barriers and debilitating, if not entirely abolishing, people's preparedness to commit to the pursuit of common interests.

One particularly potent factor was, as mentioned, above, the absence of the discontented-and-defiant recognised as symbols and appreciated for attitudes and authority. Another factor was organisational as the structure of enterprises could either thwart or facilitate formal and informal contacts among the workforce. The size of the enterprise could matter in this respect, though not as much as it might be expected. Counterintuitively, it was not the case that the smaller the enterprise was, the stronger bonds developed among its workers. What seems to have mattered more than the size itself was the organisation of the workers' community and possibilities of informal bonding, which depended on how tightly the enterprise's functional units were interconnected.

Symptomatically, as soon as a strike erupted, the management, the old trade unions and PUWP agencies exerted themselves to block communication channels and thereby to prevent meaningful interactions among people. One of the strategies was to prohibit assemblies (in one plant, no more than three people were allowed to gather at one place), to suspend passes authorising people to move between the enterprise's departments and to implement other practical 
measures (cutting off telephones, forbidding entrance to some rooms, etc.). The point was, obviously, that without exchange of information, discussion and negotiations, any common action was out of the question.

The third factor thwarting the development of social bonds concerned negative group stereotypes. Actually, the stereotypes appeared not only as a result of propagandist mongering but, first and foremost, as a consequence of diversification among workers' groups, which enhanced social atomisation. Such disintegration was spawned by granting modest privileges to some groups and making earnings dependent on employment in particular organisational sectors instead of on jobs and competences. Such regulations violated the sense of social justice as some people's paycheques were only bigger because they worked at the A department rather than at the B department. Such a division bred jealousy and contributed to the negative stereotype of the A department, especially if there was little direct contact between their workers. Such ploys and measures were, in fact, deliberately used. Another device was incorporating separate, small and specialised sections within bigger ones where work was entirely different. It was assumed, aptly indeed, that such arrangements coupled with income differences would disintegrated the collective as the smaller group would tend to seal itself off from the bigger one, while the bigger one would be hostile and distrustful towards the smaller one. Such policies had an impact on strikes.

A respondent reports: "Why am I saying it [the strike] was spontaneous? Because no one even said clearly they were stopping. A few machines stopped, people started to cluster around and discuss why the toolroom had [stopped] and whether we could as well. So others started switching off [the machines], and practically at a certain moment all the machines were shut down. Of course, a few people staunchly opposed that and kept working, but when we had an understanding, the talk was they [...] mustn't disorganise the strike. So, I say there were some strong pressure groups, but there were generally no beatings [...], two different crews worked in that one room and opinions clashed to an extent [...]. That other section crew, one that wanted to go on strike, it was a small group. They were afraid that the management could personally threaten to fire them [...], so they asked the others for help, saying they'd all strike as one group in solidarity. And that smaller crew that'd asked for help to proclaim the strike, they got pay-rises earlier and earlier announced the strike to be over. This was an ugly thing to do, and it was widely commented on, because when they were in need, they asked for help, but when they got what they'd wanted [...], they didn't want to go on striking in solidarity with others" (S 20, pp. 5-7). The same respondent points to other difficulties: "And there was the white-collar issue, too, 'cause some people said it's ridiculous if they go on strike, 'cause when 
you go into the office you don't know anyway if they're working or striking. So this had to be discussed at the workshop [...], with people there, that whitecollars were joining the strike [...]. At that moment, there was no close communication between the white-collars and the blue-collars, it means that those old antagonisms were felt, as at that moment the strike could be prolonged and demands made for the white-collars to get more, but when the news came they'd get $10 \%$ more, while the blue-collars seven hundred [...], the blue-collars were satisfied and quick to forget that the white-collars weren't just bureaucrats" (Ibid., p. 7). To dispel such negative stereotypes was an exigency that took active effort: "The situation was that they kept refusing to give the white-collars [a payrise], but because we were together at the rally in the workshop, and I also talked there that we had the same stomachs, and so on, that the same demands should be fulfilled [...], they could give all departments on strike pay-rises on the same day. They thought that by giving some departments a pay-rise, other ones would feel alienated and back off and stop striking" (R 10, pp. 5-6).

Generally, the strikers did not cave in, but in the company depicted above, the management was able to differentiate wage increases considerably, with the "meek" ones obtaining less. This shows another divisive factor at play when social protest is in the formation phase. The authorities decided to meet selected demands in order to split the revolting group and to prevent the spread of community feelings. This was a strategy designed to put down the flames of rebellion before they roared and set the entire enterprise, neighbourhood and region ablaze. Sometimes substantial populations of workers only found out about the summer strikes a few months later, when new conditions and options of communication were in place. Importantly, this was the case not only in big enterprises.

Entangled in a mesh of mutual negative stereotypes, the white-collar vs. blue-collar division, whose disintegrative impact is identified in the passage above, was undoubtedly crucial when strikes were launched. Interestingly, the division changed over the following months (which will be addressed in the depiction of the formation process of the independent trade union below).

The fourth factor adverse to social bonding was fear, above all a fear of reprisals against the protesters. Our respondents often talk of terror within enterprises (Ibid., p. 7). Tellingly, while manifestations of general dissatisfaction and critiques of the government and the PUWP were on the whole condoned, it was deemed highly "improper" to disapprove of the way the enterprise was run and operated. The more the criticism focused on the enterprise, the more dangerous it was. The defiant were disciplined in various ways, including threats of dismissal. Another frequent punitive measure involved reassignment to worse jobs, often ones with an increased health hazard, even for people with 
documented medical histories. Our respondents often report such cases. In many organisations, people very well remembered the harassment inflicted on active participants in past protests. This strong negative collective memory was one of the most important determinants of the structure of collective actions during strikes. Actually, the reflection on the organisation of collective protests was fuelled by the desire to avoid reprisals, which made people develop a fundamental sense of solidarity in common struggles. Nearly in all enterprises, the promise of non-reprisals against the strikers featured among the conditions to end the strike. Guarantees were demanded that nobody would be disciplined for taking part in the strike.

Sometimes no official representatives were appointed and even Strike Committees were not formally constituted for fear that they would be targets of future repressions. "Why the Strike Committee was not set up was rather interesting. So, as such [...] nobody wanted to lead it 'cause everybody was afraid of reprisals, that's one thing. The other thing is [...] that there was no communication as such among departments [...] somehow it was impossible to get together and strike a deal [...]. Nobody wanted to be on that strike committee 'cause we all talked about possible reprisals, and our representatives were simply people who went over to hand in those demands. But they didn't call themselves a committee nor were the official organisers of that strike. Consequently, they couldn't be made accountable for anything" (Ibid., pp. 4-5).

There is credulous ring to this reasoning as the respondent believes that active strike participants will not bear the consequences of their deeds unless they adopt "officially rebellious" roles. This naïve thinking is in itself an expression of fear in which it is unthinkable that people have the right to stand up for their interests and living conditions. This was actually a major obstacle to defining struggle as struggle, revolt as revolt and conflict as conflict. Such fear drained people of self-confidence and the sense of empowerment.

The crucial challenge was to overcome that fear, which paralysed the very thinking about action, let alone action as such. Our very general hypothesis is that the sense of community is a fundamental counter-fear mechanism. In the foregoing, we depicted social bonding within individual enterprises and indicated the factors that fostered or hampered it. When the strikes were in progress, the management and the political leadership of enterprises made every effort to forestall the transformation of workers into a social community, a collective inspired by shared goals and shared consciousness. Their measures were in general poorly effective, despite sustained efforts to antagonise people and inflame fear, mutual aversion and distrust. These attempts were overridden by various mechanisms of spontaneous social bonding. 
Joint protest actions took shape, firstly, around groups of active members of the collective - the discontented-and-defiant, who epitomised all workers' common interests and desires; secondly, around populations that formed closely-knit workers' groups as role models for other workers (such as toolroom crews and their equivalents); thirdly, around the informal networks of relationships forged among people who formally belonged to a particular unit of the enterprise people on the crew of a department, a section or a shift were not only specialised performers of technological tasks but also a community, a circle of friends.

Our data suggest that strikes were particularly difficult to launch wherever the ties among workers were loose and only based on working together in a team that pursued the same production targets. The key factor instrumental in transforming a formal group into an informal group, into a community, was the period of working together. Where the staff turnover was biggest, informal bonds were weakest and collective action was most difficult to undertake. This is what one respondent talks about: "Well, there're sections we generally have all the time the most difficulty with, such as the assembly section and a few others, with a very big workforce turnover, 'cause they're mostly new arrivals, it is a mixed group, they're people from the countryside. And, generally, uniform beliefs are few and far between among them, and making uniform claims is a problem. Basically they're satisfied with whatever they're given" (S 20, p. 3).

Such bonding mechanisms are, of course, part of sociology's basic knowledge. Yet besides such obvious and banal factors, the process of bonding, of forming communities and of developing a sense of togetherness among workers in Warsaw (and, likely, across Poland) in the summer of 1980 involved one more, far less trivial aspect. It could be briefly described as the crystallisation of a general social sense of community. Shaping the active notion of "us," which made striking possible in the first place, the elementary bonding mechanisms within enterprise communities seem to have been a harbinger of a far wider sense of community and a far more general awareness of the social "us." Our thesis is a radical one: the shaping up of social bonds within enterprises during the strikes in summer 1980 was the first substantive symptom of the birth of a general social sense of community. The discontent that motivated workers' communities to engage in collective protests in defence of their interests palpably embodied a yet vague and still inarticulate feeling of community that Poles felt in July and early August 1980. While this broad communal context was not yet patently on the minds of social actors, it certainly suffused social action and social knowledge. This knowledge predominantly concerned the mechanisms of reprisals and the reasons behind the failure of earlier social protests, though it was not a direct expression of cumulative experience. As already mentioned, 
the organisers of strikes in the summer of 1980 were not disciples of the former activists and protesters from their enterprises. Rather, they drew on generalised social knowledge, on, so to speak, society's abstract lore. This general knowledge was the basis of organisational decision-making within individual workplace settings. This meant, at the same time, that this knowledge integrated respective working communities into a far broader social "us," linking these groups to others which had engaged in similar action over years. The "we" of the protesting workforce had a social history behind it, a history populated by those who had refused to lay low in the past. In this way, a continuity of interests and an affinity of circumstances were felt and propped the self-image of people who now experienced that continuity and that affinity. People felt they were not alone, because they were buttressed by a shared history.

What remained to be done was discovering "our folks." Not yet lucid or keen, the consciousness of community, informed by the bond with the past and finding in that past takeaways for itself, charted two trajectories of explorations and references to reality. One of them focused on re-creating the enterprise's social past. This vague sense of shared experience of working people in Poland enlivened and activated the collective memory of people's most immediate tradition. The phrases "we the Ursus workers" or "we the Steel Plant workers" came to refer to something more than just the setting where people worked at that moment. The fate of Ursus or Warsaw Steel Plant working collectives came to be perceived as similar to the fate of other working collectives, and the experience of the direct forerunners came to be viewed as attesting to the reliability of general social knowledge. The memory of the past directly concerning workers of a given factory enhanced the sense of community, which was expressed in readiness to go on strike.

This consciousness built, of course, on collective memory salvaged in many enterprises in one way or another. Our data show that this active consciousness of the community affected the interpretation of the past and helped bring to light knowledge about the events overlooked in collective memory before. This is what happened at the MZK, where the former protest actions were not remembered before the onset of the strikes. Only the active consciousness of the community dug deep to disclose the events of 1976, when the MZK workers staged a powerful protest. In searching for people's own tradition, a new collective memory was formed and a new image of "us" came into being among the city's transport workers.

As a result, they started to compare themselves with and to others in a similar situation. Protests launched in some enterprises served as an impulse for workers of other enterprises to take up action. Initially, the workers of Warsaw-based 
companies followed the example of the Lublin strikers. Their potency as a role model was rooted in the perceived community of situation. It was not yet a manifestation of self-conscious social bonds, but it was likely a first step towards it. If they - people from the past - had been able to stand up for themselves and defy the government in the name of their interests, why should we not do the same thing as well? Generally, nobody tried to establish whether those interests were indeed similar to our own ones. No attempts were made to establish affinities between these sets of interests either in direct contact with the activists of old or in reflection. The fact of standing up for one's living conditions was enough.

This fact affected bonding, as it offered a point of reference for the emergent working community within a given enterprise and sensitised people to what others were doing. A vast process of social reflection and a grand conceptual project were in the offing.

Metaphorically, the strikes was an avalanche-like series of mobilisations of enterprise communities making their demands. In these mobilisations, workers were swiftly forging a community, aware at the same time that the same thing was happening in other enterprises. Workforces watched each other with a kindly interested eye, but for a while no attempts were made to communicate directly with each other. Everybody seemed to be waiting for something.

The awaited impulse eventually came from Gdansk. A communal thinking mode was already in place, but the sense of a new social "us" was still developing unconsciously. The strike at the Gdansk Shipyard, the spread of solidary actions that stirred the entire Coast region and the drafting of 21 demands radically changed the situation. Solidarity strikes were already different. The strikers transformed into a consolidated community just because a more general sense of "us" appeared, in which "we" and they in Gdansk were one group.

This was emphatically exemplified in the strike at the Warsaw Steel Plant in late August 1980. Earlier, at the beginning of July, some of the plant's departments had gone on strike for a few hours demanding wage increases. Those strikes, however, had not evolved into any determined communal action (the financial demands had anyway been fulfilled immediately). The strike that began on $28^{\text {th }}$ August was understood by entire Warsaw as a symbol of solidarity with the Coast workers and sympathy with their demands.

Our data suggest the following dynamics of the situation. Similarly to the strikes discussed in the foregoing, the strike of August 1980 was initiated at one of the Steel Plant's departments and soon spilled onto two other ones. Over the following dozen hours, it spread further to include the entire staff, both production workers and part of the administrative segment ("the office building") alike. That strike differed from the previous ones in a number of respects. 
First of all, many of our respondents say that the idea for the strike was put forward by particular people. If individual initiatives transformed into a vast communal action, it can be assumed that people had been spiritually prepared for such a mobilisation and for making thousands of individual decisions to join the strike.

Secondly, the strike immediately took on highly organised forms, following the models set by the Gdansk strikers, the intended recipients of solidarity and support. This is clear in reports from the Warsaw Steel Plant: "So I believe that they [the strike initiators at the Steel Plant] had no experience, that's why the strike started at the A department, at the medium-fine rolling mill, and it was initiated by $\mathrm{X}[\ldots]$. And he has a very strong personality. $\mathrm{He}$ is very persuasive, has the gift of the gab, which was indispensable back then, and the A department had practically no striking experience [...]. Certainly, if the A department had been first to go on strike in the whole country, I don't know whether that'd have worked" (S 4, p. 15). If the strike at the Steel Plant worked, it was certainly because of the Gdansk example, our respondent insists: "[people] realised that if somebody'd been on strike for nearly two weeks, since the $16^{\text {th }}$ or $14^{\text {th }}$ of August, I don't remember exactly, and they'd endured somehow, we can endure that too. A day or two, or a week or two weeks, perhaps, we don't know, that consciousness wasn't yet around, but we already knew that somebody was handling it all right. And that comforted us. But had they started it alone, I don't think we could've organised something like that at all. That Gdansk strike was a stronger stimulus that it was possible, that you could organise something like that" (Ibid., p. 15).

"One department started it, in fact a group of workers did [...], he [one of the initiators] basically can be said to have proclaimed the strike. He put forward those three demands [...] and asked the people to contribute to the strike as a solidarity strike in support of the workers and their demands and, at the same time, in order to join and somehow bargain about them at the Steel Plant as well. And that was initiated in one department [...], later, liaisons, so to speak, went to other departments, and they proclaimed the strike too, well in the first stage, three departments stopped [...] and later other ones started to join them [...], so that, practically, within one day the entire Steel Plant came to a standstill" (Ibid., p. 5). The demands included: "free trade unions, freedom of expression in the Polish mass media and recognition of the right to strike" (Ibid., p. 1). They encapsulate the ideological "ignition" of the strike, whose character was emphatically defined as solidary: "with an address enclosed that this is, generally, a solidarity strike in support of the striking workers of the Coast region [...], and it was announced at the medium-fine rolling mill through a megaphone" (Ibid.). The strike initiators began to disseminate their idea resolutely, briskly 
and determinedly. A megaphone was used, an announcement was made via the factory's p.a. system and a placard was placed at the gate with details of the strike explained and an appeal to all workers to join it.

The gesture of solidarity with the Coast strikers, which seemed veritably a moral obligation, was simultaneously a mobilisation in the local workers' own interest. As a respondent explains: "We knew that [...]. We realised that as other departments joined the strike, an agreement would be reached quicker in Gdansk, and we'd be all eventually able to begin seriously with that renewal people were slowly starting to talk about. And that was the weightiest argument, and also $[\ldots]$ there were voices from the staff that we showed solidarity with the Coast region, but we also wanted to obtain something for the steel industry, for ourselves [...], the fight was about nationwide issues, but also about our own ones" (S 7, p. 4). The situation was clear: the strike backing the demands of the Coast workers could only finish when an agreement was reached between the strikers and the authorities. At the same time, the strike's objectives also included the interests of the Steel Plant workers. "Demands" became a buzzword on the spot. As the demands concerning the strikers' own enterprise were being formulated, the organisational structures of protest actions were being formed and Strike Committees were being set up: "As soon as we shut down the rolling mill [...], the Strike Committee was elected in our department [...]. We went to the shift foremen's room, and we simply made it into the interim Strike Committee. The entire staff gathered in the finishing room, where $\mathrm{Mr} \mathrm{X}$ started a rally - he simply told us what the strike's aim was and that it was a solidarity strike in sympathy with the Coast as well as immediately the catchphrase 'bring on our demands' appeared [...]. And I must say, I'm proud to say I was the first to bring in three demands on a sheet of paper. I remember them even: the first demand was about reinstating the Steelworker Charter, the second about equal pay for production workers [...] and process engineers, and also about making our Factory Council answerable for what they'd done over the past five years and the CRZZ for the past five years" (Ibid., pp. 1-2).

"On my way to work, I read an announcement that a strike'd started and in our [...] room, which we shared with another work team, most of the department's workers gathered; and they decided, spontaneously and immediately, to select a Strike Committee and told that Strike Committee to get detailed information about the strike action and then to develop that strike action across the department. I must say that we acted very quickly in that situation. What is the aim of our strike? It is a solidarity strike in support of the shipworkers from the Coast, both Gdansk and Szczecin, and we want to find out what is actually going on in Gdansk [...]. And then we went back to our department. We even divided the 
roles among us to quicken up and streamline things [...]. I went to the most important department $[\ldots]$ the furnace room. And I made the case there $[\ldots]$. The colleagues there said that we were right indeed to demand that and decided to join the strike with us [...] and it was obvious then that the steel shop was shutting down. And when the steel shop doesn't work, no other department can do anything for they've got nothing to produce" (S 6, pp. 5-6).

"In each department, a Strike Committee was immediately formed and went about organising things. First, demands were collected and drafted. Second, delegates to the all-factory Strike Committee were elected. Third, the factory property had to be secured. [Interviewer: 'How did the strike develop?']. In a flash. [Interviewer: 'What was being done?']. Everything. Literally everything, not to overlook anything, either securing production or making sure that the workers were safe as well as that no unauthorised person entered the plant [...]. The Strike Committee was made up of the departmental strike committees. Simply, to avoid further ado, all representatives of the departmental strike committees were appointed to the Factory Committee. [The departmental committees] were selected by sections, departments, work teams. Candidates were put forward. Across the departments, there was urging: 'Set up committees here, in your departments. Whom would you see on such a committee, who of you can represent you as a social and occupational group?'[...]" (Ibid., p. 7). "Certainly [candidates to Strike Committees] were people not so much unknown as rather having informal authority. They were authority of sorts, but for one reason or another they'd stayed away from socio-economic politics before. In fact, among the praesidium there were four PUWP members, but nobody objected to that; elections followed like that: a candidate was proposed by those gathered, and was said to be a good choice and, say, you stood up and said you'd worked for so and so many years in this or that job, had no criminal record, were no shirker and no drunk. 'Can anybody present contradict what I'm saying?' And if anybody stood up and said it wasn't true, 'cause the person had a shirking bout some six months before, that candidate was automatically crossed out. This aspect, the moral aspect was taken very seriously. Not to have anybody saying later: did you do a good job electing drunkards and slackers!” (S 7, p. 4).

The demands from individual departments were compiled and passed to the Factory Strike Committee, where a list of top demands was ultimately put up. Negotiations with the Steel Plant management and the Minister of Heavy Industry (Franciszek Kaim at the time) concerned nineteen demands (respondents from one department talk about eighteen demands, while two interviews mention nineteen of them). The impact of the Coast example is very vivid. This invites the question how steelworkers found out about the details of 
the events in Gdansk. Our respondents primarily refer to the list of twenty-one Gdansk demands, which were printed in the Sztandar Młodych..$^{44}$ At the same time, as one respondent explains: "before that main solidarity strike, towards the end of August, flyers appeared in some departments, urging to join the striking workers of the Coast and listing demands, those 21 demands" (S 4, p. 4). Thus people knew about the demands, about the formation of Strike Committees and about the Inter-Enterprise Strike Committee. The available information was very general, but it proved sufficient to spur action.

The Gdansk example did not impact people either through any particulars of the Coast strike organisation or, even less so, through any direct instructions. Rather, it affected the imagination. The symbols provided by the striking Coast workers served as a trigger and a behaviour model. This model, however, had to be fleshed out by lived experience. This is what happened at the Steel Plant. The impulse from the Coast developed into a system of activities modelled upon the Gdansk example. It was governed by the logic informed by the feeling of affinity, which was sparked by the first gesture of solidarity in going on strike. This is the reason why the strike at the Warsaw Steel Plant resembles the Gdansk Shipyard strike. The two did not only rely on the same organisational structure. They also shared symbolic objects and ritual collective behaviours, flaunting similar attitudes and feelings: "when the SC assembled, when they negotiated, for example, with the management, at any bigger gatherings, the national anthem was sung to end the meeting [...]. A mass was read $[. .$.$] . People had various ideas [\ldots]$, why that mass was read $[\ldots]$. The mass was read because many workers are religious [...], because of their jobs [...], and steelworkers, too; well you could say, belief in faith, in a superstition or something, in hard work which isn't always safe. So an idea appeared to read a mass. Cardinal Wyszyński was asked whether [...] a mass could be read at the Steel Plant, and secondly, to authorise some priests [...]. Within an hour or two, people made a big wooden cross, put an altar together and a holy mass was read here, in front of the main gate" (Ibid., p. 11). "Everybody wanted that mass, and there was an enormous pressure from the people to hold a mass, actually $[. .$.$] to hold a mass in each department [...], that we couldn't$ agree to, because it was only the beginning of the strike. A mass was read twice on Sunday [...]. Why did people need it so much? First, as everybody knows, most workers, like a huge majority of Poles, are Catholic; besides, the

44 The Sztandar Młodych (literally The Banner of Youth) was a youth daily published in Warsaw from 1950 to 1997. (translator's note) 
situation, let's face it, was quite hazardous, and everybody was aware of that. In previous years, strikes had been cracked down on violently, so in this sense, people better remembered what mattered most to them. Well, what matters most to a Catholic is being close to God above all [...]" (S 3, pp. 3, 15). "I don't know whose initiative it was, but I liked it a lot. I guess I know why this mass took place among other things. Because after the strike was over, I found out that the Strike Committeed wanted to contact a lawyer, an economist, for we wanted to discuss various issues, and there may have been an idea to follow the example of the Gdansk or Szczecin MKZ and do something like that here, in Warsaw [...]. And it was likely then that the idea appeared to, well because, listen, people'd stayed after the night shift and there're many religious people here, to follow the Coast example and organise, that is, hold a mass. And the idea was quickly picked up" (S 7, p. 9).

Were the national emblems and the mass a spontaneous idea of the Steel Plant's workforce on strike, or were they a conscious emulation of the Shipyard workers? Our respondents' views vary, and it is actually impossible to offer a conclusive answer. The logic of the Steel Plant strikers picked up and carried on the elements they shared with the Gdansk shipworkers. When people took action as a gesture of solidarity, they understood they embraced the same order of attitudes and values. If some of them knew about the liturgical element of the Gdansk strike, they must have seen the re-enactment of the mass as their "natural" need. If they did not know about it, the mass must have been their acutely felt and ineradicable need. That the same rituals took place at both venues tangibly corroborated the bond between "us" and "them." This is, in all likelihood, the central relevance of this experience.

The model-setting influence of Gdansk was not only limited to the emotional and symbolic layers. The solidarity strike at the Warsaw Steel Plant called for a palpable acknowledgment. One of the first things the Factory Strike Committee did was sending a delegation to the Shipyard: "the management was applied to for a car, a delegation was sent, two Polonezes ${ }^{45}$ drove off [...]. One belonged to the management, and the other to the MPT. ${ }^{46}$ The director paid the expenses" (S 4, p. 8). "It was made simple, for they [five people went] got business trip assignments saying that the Factory Council

45 The Polonez was a popular car make produced in Poland (specifically, in Warsaw) under licence from Fiat. (translator's note)

46 MPT is the acronym for the Miejskie Przedsiębiorstwo Taksówkowe, i.e. the City Taxi Services. (translator's note) 
dispatched them as workforce members and representatives to the Strike Committee in Gdansk. The assignments were each signed by Leszek Wałęsa up there" (S 6, p. 8-9). Asked why a delegation was sent to Gdansk in the first place, the Steel Plant strikers cite two basic reasons, a rational one and an emotional one. The rational reason is explained as follows: "We sent our representatives over there $[\ldots]$ because it was generally one of our conditions: we'd stop striking if they went over there and told us on coming back that the strike on the Coast was over. We couldn't trust radio and TV news because we knew it could be redacted in various ways, and we simply didn't believe it to be real facts" (S 3, p. 2). The emotional reason is described as follows: "Cause, when it was said at once that we as the Steel Plant stood in solidarity with the Coast, and especially with the shipworkers in Gdansk [...], the decision was made to simply send them a written statement that the Steel Plant had been on strike for that many days as a sign of solidarity and total support for their 21 points, yes, demands, and also wanted to do something for those demands to hold for entire Poland, and not only for them over there, plus for its own demands that it had and would go about by itself. And that the strike here would end as soon as their strike over there did. You can say people went over there with a double purpose, first to let them know that the Steel Plant was on strike, which was in fact reflected in [...] the strike bulletin issued by the paper Solidarity in Gdansk [...]. [Second] to bring some resources [...], so that people here could simply see what those workers, to obtain more information" (S 4, p. 9). On coming back, the delegation confirmed that an agreement had been signed at the Gdansk Shipyard and brought over the Gdańska Solidarność (The Gdansk Solidarity) (a strike newspaper) along with the Shipyard workers' flag: "That delegation that had been to Gdansk came back and even brought the flag of the Gdansk shipworkers. [When] Wałęsa came here during the strike on $3^{\text {rd }}$ October, that token one, it was also brought out and displayed, it's cherished 'cause the steelworkers got it from the striking Gdansk shipworkers" (Ibid., pp. 9-10).

The two reasons for the trip to Gdansk were equally relevant. Above, they are only playfully defined as rational and emotional. In fact, both bespeak the same need to chronicle the sense of bonding. For solidary actions to make any sense, they had to be continued until the common goal had been achieved. The radio and TV could not be trusted, and an eyewitness's proof was needed to know that the Coast strike was indeed over before the Steel Plant strike could be ended. At the same time, as the Steel Plant expressed solidarity with the strikers in Gdansk, this support had to be communicated to them, for solidarity unrecognised by its addressee is pointless. Such communication could reify the sense of community. 
"So the four demands remained, and those nineteen were signed with a staff representative in attendance on the night of the $31^{\text {st }}$. [...] We resumed work in the morning. Yes, the strike was ended in the morning. It went like that: on the $31^{\text {st }}$ the strike in Gdansk finished, our delegation came back from Gdansk and we also ended it. At two in the morning the delegation came along, and at four our demands were signed here, in this room" (S 7, p. 7). The room was decorated with white-and-red flags, a red-and-black steelworkers' flag and a white-andblue one, brought over from Gdansk, the shipworkers' flag. A new era of social life had begun.

To the best of our knowledge, the strike at the Warsaw Steel Plant was the only solidarity strike in support of the Coast demands in what was to become the Mazovia Region, though similar actions were also planned at other enterprises, and the steelworkers were not the only workers' delegation from Warsaw to Gdansk. The Coast strike was relevant first and foremost because its impact capped off a long process of new consciousness formation among working people in Poland. The Gdansk example made workers aware of the road behind and ahead of them: it helped them grasp the previously vague motives behind their actions, assess social reality, understand desires that animated them and set common goals. Discontent, the sense of threat, needs and values turned out to depend on engagement in shared life and shared fate. Nonetheless, this social cluster was by no means homogeneous. Just the other way round: the awareness of sharing in and depending on the common fate of entire society compelled an appreciation of how diversified people actually were. As interests and values were patently varied, people started to perceive clearly who shared their beliefs, aspirations and attitudes and who did not.

It was also the moment when people began to realise that the previously uncoordinated and isolated actions had been fuelled the same motives and represented the shared experience of the overall social situation; and, finally, that the chaotic movement was enlivened by the same spirit. All this added up to an awareness of being united in the common cause. When this initially selfunaware mobilisation focalised around a clearly defined and commonly accepted goal, a social movement came into being in which human masses pursued one cause. A lucid and obvious definition of the situation drove those human masses to revolt and protest. That breakthrough moment also projected a new, shared definition of the future. The past and the future emerged concomitantly and as mutually interrelated. The picture of the current situation took shape when it became clear what our point had been and why, and what our point was and why exactly that. 


\section{The Common Definition of the Situation}

In the following, we will focus on the last factor that formatively influenced the summer 1980 strikes. We called this factor the definition of the situation which pushed many workers' communities to launch collective protests. Of course, defining the social situation was a process. As already observed, mobilisations in early July and mid-August 1980, though successful, had left something to wish for. Intellectual and emotional tensions lingered on persistently, and debates went on restlessly. This was easier now since the protesting workers had already forged communities in action. How quickly the rational definition of the social situation was "ripening" can be seen in the progression of the strikers' demands.

The interviews cited above confirm that, at first, strikes were generally launched to enforce certain group claims, mostly quite limited and simple: as the economic situation worsened and prices rose, people wanted higher paycheques. Conspicuously, such demands were usually expanded as soon as financiallymotivated strikes had started. People seemed to conclude that if they had already gone on strike, it would be a waste of their energy to rest satisfied with a few hundred zloty, while so many other issues still rubbed them the wrong way. Consequently, demands were made concerning the organisation and operations of enterprises. Such an extension of strike claims marks, in itself, a re-modelling of the prevailing viewpoint as the sphere of reality the strikers seek to influence changes. This represents a transformation of the self-image: while in retrospect the actors themselves believe the expanding list of demands to have been simply "unsatisfactory," extending this list, in fact, portends a re-invention of their social role. People grow confident that they can indeed change the present situation. This situation ceases to be the only possible form of reality.

The process is illustrated by a respondent who retells an encounter with highranked PUWP and government functionaries in July 1980: "Karkoszka ${ }^{47}$ came and Minister Kopeć ${ }^{48}$ and [somebody] from the machine industry, the district secretary [...]. We were prepared for the meeting with Karkoszka, and I was then among the three; later a few other people joined us, and we started doing things a bit, we were prepared [...] Minister Kopeć took the floor first and complained about difficulties as was the fad back then. Gierek would complain and everybody would about objective, subjective and other difficulties [...]. Then the boss spoke $[. .$.$] typical success propaganda - that we complain, but fail to see the$

47 Alojzy Karkoszka, a former Deputy Prime Minister, a member of the Political Bureau of the PUWP's Central Committee. (translator's note)

48 Aleksander Kopeć was the Machine Industry Minister. (translator's note) 
achievements, and he went on about achievements. Then I spoke as well, I say we know about successes all right, you blow every trifle up into a great achievement, that's your big successes. And we know the things to be appreciated, but we're here about shortcomings, that's what we've gathered here for. And as far as Karkoszka is concerned, whatever he could get from the offices answerable to him, it's a done deal, comrade P., put it down, you'll have that overpass, the junction, we'll see about that [...], consider it done, and we'll contact the top tiers about the other things [...]. Most people were glad leaving the meeting, but despaired the following day, when they saw what that meeting had actually given them, as it was basically nothing [...]. Only that people'd offloaded" (R 10, pp. 8-10). "When we left the meeting," another participant recalls, "we were leaving, right, the way you leave a meeting, still discussing things, so when it was over, we felt simply like fools, forehead-slapping, what was it actually that we'd come here for? Idle promises, put down this, put down that, that was it. And the guy put it down, playing dumb all over again" (S 21, p. 4).

"The day after the meeting, a strike began. The PUWP secretary had no doubt that the two were connected ..." (see P 9, p. 2).

Importantly, in these and other interviews, the same insight is reiterated, insisting that people must start to shape their social world by themselves. This means that elements of the definition of the social situation have been redefined and what underpinned them before has been invalidated.

A new definition of the situation is always formed in a continuous process, in which action and reflection alternate. People gradually come to discern the relevance of their actions. A breakthrough moment occurs when they ultimately grasp what their behaviour actually means.

When the strikers in Warsaw found out what the twenty-one Gdansk demands were all about, they comprehended the full meaning of what they had been doing so far. The signing of the Gdansk accords was a breakthrough moment for other strikers.

The definition of the situation that motivated people to go on strike throughout the summer of 1980 must be gleaned from the actors' testimonies. Admittedly, when they engaged in action, they were still unable to account for all the elements that went into the making of their motivational definition of the situation. But what they construed as the meaning of their actions had been there before in the form of active factors provoking them to adopt certain attitudes. As attitudes transformed into a system of common action, the situation changed and an entirely new self-awareness arose. But what was only later to be framed as rational and systematic by the actors was already inscribed in the activities they undertook in the summer of 1980. 
The beliefs that made up their definition of the situation were by no means homogeneous. What some people had viewed as obvious even before the negotiations between the government and the strikers in Gdansk were over was only fathomed by others much later. Given this, there must have been people whose active thinking reflected what was to be accepted as an "obvious" belief by everybody.

\section{Intellectuals and Big Industry Workers: Generational Groups}

It would be very difficult to depict individuals who stirred the intellectual ferment among their co-workers. Undoubtedly, those whom we labelled the discontented-and-defiant inspired and promoted reflection. In the next stage, this function was picked up by the organisers and first leaders of new trade unions. However, it seems more pertinent to identify social groups that exerted an especially profound influence on public reflection. We posit that generational groups which had particular biographical experiences were hubs of this intellectual effort. It was the way in which these groups thought that formatively contributed to the new definition of the situation. In Warsaw, two major generational groups of this kind can be distinguished. One of them comprised the intelligentsia and the other, workers. The "intelligentsia" generational group consisted of people aged 30-35 years of age in 1980. Their formative experience involved the events of March 1968. The "worker" generational group included slightly younger people, aged ca. 24-28 years of age. Their formative experience dated back to the June 1976 events. Why do March'68 and June'76 seem to count as generation-shaping moments?

For both groups, the experience of momentous socio-political developments marked the onset of their adult social biographies. As eye-witnesses or participants, they simply had to take a position on those events. It was the first time that they had had to relate as adults to what was going on in social life. This laid the foundation for their self-awareness and fostered their political consciousness, values and self-images as community members. We do not claim that they all had the same worldview. But though ideologically differing, if not polarised, they had the same point of reference in having to side with one of the parties to the conflict, this choice determining their individual identities and demarcating their social communities.

When we talk of the two generational groups as vehicles of a new popular consciousness, we mean those who, in most general terms, sided with society and against the government. This (often only latent) expression of allegiance bore its explicit fruit. We assume that people for whom March'68 or June'76 stood out as 
formative moments were a similarly distinguishable group within the population which supported the party-and-state apparatus. This is a purely theoretical conjecture which our findings could not prove or disprove. At the same time, this author has not studied PUWP functionaries closely enough to offer any reliable assessment.

Besides, it is clear that other sociological groups actively developed the new definition of the situation as well. Just as the biographical experiences of the intelligentsia and workers - the March generation and the June generation clearly dovetail, the affinity of intellectuals and big industry workers is also undeniable.

Further, the workers' groups that fostered the new consciousness boasted better education. Such groups, characteristically, worked in big factories and had specialised (usually secondary) vocational education. Another important group to consider encompassed democratic oppositionists. In Warsaw, they formed a relatively broad social circle whose social relevance cannot be overemphasised, even though they did not directly influence the mobilisations. The very fact that democratic oppositionists were there and were fundamentally active was preciously symbolic, irrespective of the particular political or social agendas they championed.

\section{The KOR and the Democratic Opposition}

What has come to be referred to as the democratic opposition is a fascinating social development in its own right. A small group of Warsaw workers stayed in touch with the activists of independent social organisations. Some of the discontented-and-defiant regularly communicated with the independent activists. What such contacts looked like is explained by a respondent: "I found out in May that I was ill and went into therapy [...] at that time I was in Zakopane, those first discussions with Y. [...] Y said he was afraid 'cause I was so pumped that I'd shoot 'em all dead. When you've got no information and don't take things with a cool head, you'd just put them up against the wall and shoot right away. I thought like that - something didn't feel right. But I didn't know what it was. Of course, Y had more information than me. [...] I knew Y was somebody I can learn a lot from. [...] I listened rather than talked. We noticed right away that Y knew about things. And he had the literature [...]. This was the first sign that he had some contacts. And discussions with Z, too, of course. The joke was, when we had such a lively Sunday, that we outshouted the machines. We hung around and yelled, arguing like hell, everybody had their own opinion [...], and we didn't discuss politics then, but all issues. [...] I remember like it was today 
that once we had a laugh about the 'deer in a rut..99 We argued for a good four hours, and I grew completely hoarse, and so did he [...]. These discussions made us closer and started to absorb us [...]. After some time I told Y [...] I'd bring a friend along. Of course, $\mathrm{Y}$ was cautious as usual [...], but I say he's a trustworthy person, he's got his opinions and is a very interesting man who can do something. And Y agreed. Y was a good psychologist and judged people quite well. $\mathrm{He}$ and $\mathrm{Z}$ hit it off immediately [...] $\mathrm{Z}$ was delighted with what $\mathrm{Y}$ was saying. Anyway, he also knew stuff. 'Cause we'd literally been devouring that literature for months. I'd sit up long into the night and read. Any moment I had, at work, or wherever else, I'd sit down and read right away. I devoured everything: philosophy, some psychology books Y gave me, I read basically everything, in particular history [...]. Over those five months, I learned more than in all the years at school. Y promised [...] and brought us a big bag with books - we were delighted we had so many and started to distribute them [...]. We didn't get anywhere near enough of Robotnik ${ }^{50}$ - only a dozen copies or so. We took those books, but money was a problem 'cause I had a wife and a kid to provide for, I earned not even five... it was little, I scraped as much as I could, together [with Z] to buy books. Our principle was that we must have them all. Later we specialised. Z's job was to disseminate the literature and mine to yap, that is, to mouth off. Our first meeting when I went yapping so hard was before the $8^{\text {th }}$ Congress [of the PUWP]. I gave a really sharp talk. The first question was about the USSR. And I described what that heartfelt friendship was all like. At the end, I said: isn't it so that this friendship, perpetuated in thousands of slogans, is based on the principles which Chamfort summed up in one sentence: 'Be my brother, or I'll kill you.' D'you know what that could mean back then? People looked as if something had hit them" (interview J, pp. 1-5).

Contacts with democratic oppositionists stimulated young workers' intellectual and social development. The links between worker activists and Warsaw's independent intelligentsia were very unlike what the conspiracy theory champions paint them to be. Their bonds were spiritual rather than political or organisational.

Such bonds were fostered mainly through the independent press and book publishing. The direct influence of samizdat publishers is difficult to assess. One reason is that we have only fragmentary evidence. Another, more important

49 An expression used in Poland to refer to popular kitschy paintings of sylvan landscapes. (translator's note)

50 The Worker, an influential samizdat periodical. (translator's note) 
one is that our respondents talked about the independent press in strikingly vague terms, suggestive of a lingering fear. The general impression was that in December 1980 and January 1989, this was still a subject not to be canvassed freely. It was popular knowledge that there was the independent press and the "oppositional organisation." At the same time, our respondents claimed that samizdat publications had a small readership: "Here, at the XX, there was no independent press at all. [...] People had no idea about things. They'd have heard about, say, the KOR, the most famed thing, but they'd no clue about other political organisations or the $\mathrm{KPN},{ }^{51}$ and stuff $[\ldots]$ not what they were, not what the acronyms stood for" (S 4, p. 5). "You mean, was it something organised in advance, a hidden spirit that copied the illegal newspapers and inspired people? No, nothing like that in our factory. There were, surely, sympathiser groups affiliated with various organisations and - I don't know what to call them - that publish newspapers, but they were groups that had no influence on the workforce as a whole [...]. That movement was not popular. If there were people involved in this, it was a closed group" (S 7, p. 36). "No, you know, even if there was any, I had no access to it. As I say, if there was any, it was very small and accessible to people who could have access to it or had access to it through another channel, purely occupational simply" (S 6, p. 13). "Individual people had various... people showed flyers to one another, or some newspapers with that stuff which were published clandestinely. They'd be shown in mutual trust. [...]. [Interviewer: 'Were those newspapers exchanged on a big scale?']. Not really, no" (S 66, p. 27). "You could only say that we knew about but one organisation, about the KOR, which well... simply not from any reading or brochures that found their way to the factory, it was a rare occurrence and always in secret [...]. [Interviewer: 'But did you get any samizdats or not at all?']. Very rarely only, and we read them fearfully in holes and corners [...]. Yes, from time to time, but there were no regular supplies, only sporadically $[. .$.$] . By chance, we got it from$ people from other departments. There was no regular courier [...], every now and then only, and they were copies, not originals, typed copies. But we knew that the KOR was kind of the first organisation that stood up for, well, workers" (S 38, pp. 13-14).

These responses imply that a certain taboo is violated if talking about this topic and prove that only few people regularly read the independent press. But,

51 Konfederacja Polski Niepodległej - the Confederation of Independent Poland - a political party with strong nationalist leanings, founded in 1979, unrecognised and persecuted by the communist regime. (translator's note) 
characteristically, information about samizdat publications and the democratic movement circulated anyway. Clearly, such information was transferred along very "intimate," so to speak, social channels. A co-workers' group did not seem to guarantee enough security, and information was only shared with the family and close friends. As fear was very strong and deep-running, the independent press, along with the information about it, was disseminated at the very basic level of social relations.

The impact of the democratic opposition is fascinating to study. This impact, rather than direct, was primarily symbolic and affected people's attitudes and spontaneous reflection processes. Characteristically, the differences in the agendas of particular groups within the independent movement were viewed by the broad public as, basically, minor. Let us define the relevance of the democratic opposition to the development of Solidarity.

The founding of the Workers' Defence Committee (Komitet Obrony Robotników, KOR) was a genuine breakthrough moment. The KOR became a symbol of the bonds sprouting between the intelligentsia and workers. The cultural elite, professors and writers stood up for workers and in doing so not only defied the regime but also promulgated a moral agenda to vindicate their position. As a result, the workers' protests of June' 76 drastically differed from the picture trumpeted by the government. At the same time, KOR activities highlighted the values which were showcased in the workers' protest. The very fact that the KOR was set up lent heightened moral dignity to the protest actors, as its agenda restored self-respect to workers. Notably, the crackdown on the 1976 protests was followed not only by persecutions, but also by a concerted campaign of moral shaming. The government made every effort to discredit the striking workers before the public, using not only the mass media, but also "events" orchestrated all over Poland in which workers were forced to participate. In Warsaw, a huge rally was held at the $10^{\text {th }}$-Anniversary Stadium (the city's main and biggest sports stadium), with thousands of people in attendance, where the "sycophant" intellectuals led by Stanisław Ryszard Dobrowolski denounced the Ursus and Radom workers as rabble-rousers. In our data, the memory of those events is highly relevant to Warsaw workers as an unforgettable experience of humiliation and a turning point at the same time.

The government-disseminated insulting image of workers and the disgrace of having workers themselves take part in the spectacles of shaming proved decisive factors in forming the public appraisal of the entire Gierek decade.

In such circumstances, the founding of the KOR had a few direct and indirect effects. First, it initiated an independent movement to aid the persecuted victims; second, it launched a counter-image which salvaged workers' dignity, 
vilifying the government; and, third, it changed a general social attitude to the intelligentsia and the cultural elite. People of high social status - professors and authors (as well as students) - not only repudiated the government, but also advocated for victimised ordinary people, voluntarily putting themselves in their shoes. This radically changed not only the image of the intellectual elite but also, probably, the image of the intelligentsia as a social group. Before, the worldviews of the intelligentsia might have diverged from the "official canon," but they had anyway been stereotypically considered the regime's allies. The $\mathrm{KOR}$ and the later democratic opposition undermined and dismantled that image. (Importantly, in official journalism various measures were applied to sustain the idea of the government-intelligentsia alliance. An excellent case in point is a series of articles published in Polityka in 1977 or 1978 at the instigation of Jerzy Urban. ${ }^{52}$ The first article in the series was authored by Kowalczyk, who, on behalf of the technical intelligentsia, upbraided the humanistic intelligentsia for flawed economic policy-making, equating the humanistic intelligentsia with the authorities). Clearly, a crack in the intelligentsia image was emerging, with the regime-supporting intelligentsia contrasted with the government-opposing intelligentsia, who cherished moral values and public good. This is where the divided social collective started to morph into a social community. Society began to split away from the party-state and seized opportunities for establishing its own identity. The slogans of the democratic opposition might not have been unanimously endorsed, but one thing was certain: their voice was an authentic voice of society. Besides, in practical terms, the democratic opposition formed a distinct group within the intelligentsia that could be approached for help and advice.

The founding of the KOR and the democratic opposition movement was also of immense importance for the intelligentsia themselves and, in particular, for the opinion-making circles. As independent institutions championed their agendas of struggle for human and civil rights, artists, authors, scholars and journalists could not but firmly define their position and choose their identity. The independent press and samizdat publishing, which flourished despite repressions, were certainly a highly tempting outlet and, in extreme situations, a real alternative to the official channels of expression. They enabled people to speak out abiding by their own conscience. At the same time, the wide platform

52 A writer, journalist and politician. In 1981-1989, he was a government spokesman and press secretary to General Wojciech Jaruzelski. (translator's note) 
of independent social activity triggered real differentiation of worldviews, which in turn nurtured reflection on social matters.

The democratic opposition's immediate impact consisted primarily in fostering an independent information flow, starting independent social initiatives (such as free trade unions and the Towarzystwo Kursów Naukowych [Society for Academic Courses]) and maintaining direct contact with a relatively small group of opinion leaders from enterprises, whom we have dubbed the discontentedand-defiant. The Robotnik (The Worker) magazine turned out to be very significant to the workers' community.

\section{The Pope's Visit and the Catholic Church}

The KOR's social impact largely and relevantly converged with that of the Church. ${ }^{53}$ The way the KOR and the entire democratic opposition interpreted the 1976 events was powerfully reaffirmed when Pope John Paul II came to Poland in 1979. The pope's visit consolidated the emergent new consciousness and occasioned an enhanced experience of the communal spirit. Society came to embody and see themselves as embodying a community of values, historical tradition and national interests, independent of the regime and its interpretive framework. Each of the Pope's gestures and utterances reasserted society as a historical agent and seemed to address each person as an individual who was responsible for his/her life and co-responsible for the life and continuation of the entire community and national culture. Most importantly, the Pope underscored the inalienable human right to live according to one's own conscience and to enjoy human dignity paired with the right to influence the life of one's social community. That the rights of the citizen were unambiguously treated as canonical human rights had an enormous resonance, and the fact that while traversing his homeland the Holy Father time and again referred to the nation buttressed the sense of social bonding.

Spiritually poignant as it was, the Pope's visit also induced another constructive experience. Over that dozen days, a wave of freedom swelled across Poland. In towns and villages people could behave freely without fear. The few days of freedom also abounded in spontaneous organising underpinned by

53 As Poland has long been and still is a predominantly Catholic country, it has been and still is customary, even in highly formal and/or scholarly contexts, to talk simply of "the Church," dropping the "Catholic" modifier. This convention and attitude are reflected throughout this volume, and wherever "the Church" appears the reader is supposed to understand that the Catholic Church is meant. (translator 's note) 
very different principles than those applied by the government and experienced daily in Poland. Namely, the crowds following the Pope (and they were crowds indeed) proved capable of self-discipline as people simply "adjusted" to each other without any threat of violence.

The organisation of the Pope's visit was a social action on an unprecedented scale. Thousands of people were involved in its preparation and implementation. Even the simplest roles, such as in cleaning or technical services, afforded an opportunity to learn something about social action. Additionally, the general public could find out about various organisations which coordinated the venture alongside the clergy, for example the KIK (Club of Catholic Intelligentsia). As such, people learned whom else to contact for help and advice.

Our research implies that, in Poland, religion is treated primarily as a source of moral values, and it is the responsibility of the Catholic Church to express and defend these values. "Religion is the mainstay of human dignity, it teaches respect for your neighbours, and it teaches what law is," says one of our respondents ( $\mathrm{S}$ 66, pp. 17-18). Another respondent specifies this thought: "The sermon opened people's eyes to see that this rule of law was not what it ought to be" (S 7, p. 10). In breakthrough moments, "when human lives are directly at risk," says another respondent when explaining why the mass was read during the strike in August 1980, "people embrace Christian morality and God" (S 3, p. 7). Yet another respondent states that "when you realise they may shoot at you, you think of religion" (S 36, p. 5).

Religion as the source of the individual's spiritual worth and the mainstay of human individuality is the most pronounced element of Polish religious consciousness. Consequently, the Church is regarded as obligated to defend human and civil rights, which are morally validated by religion. This new form of religious consciousness seems to converge with the fundamental tenets of the democratic opposition movement. At the same time, there is also a more traditional form of religious consciousness which, less liberal while more authoritarian and dogmatic, very closely associates Catholicism's universal ideas with national thinking. In this ethos, the Church is supposed to cultivate and defend national tradition rather than champion universal moral principles which can be given a nation-specific interpretation by the community.

These two varieties of religious ethos and responsibilities ascribed to the Church were essentially differential in terms of people's consciousness. They also differentially affected people's actions. The data we generated reveal a clear connection between the ways Solidarity functioned at enterprises and the ways in which the trade union's activists interpreted religion and the Church. Therefore, interpretations of the role that religion and the Church have in 
social life are an essential element of broader worldviews, and differences in such interpretations can be regarded as an indicator of a more general distinction between liberal and authoritarian attitudes. At one pole of our axis, the new consciousness is bound up with a tolerant ethos of openness, spontaneously established rules of action and ongoing deliberation about what to do next; at the other pole, there is a less open and less tolerant ethos which prioritises group values and authority, protects the "group spirit" and invests more in controlling people's compliance with the rules than in mechanisms of instituting rules.

Within these ethoses, more and less authoritarian attitudes were expressed, for the catchphrase of democracy and democratic values was uniformly the most precious element in the new consciousness. A more liberal democracy and a more authoritarian democracy are terms that best depict those fluid distinctions typical of the period. We treat this differentiation as a structural axis, because communities in various enterprises where we conducted our interviews could be arranged into a continuum. Solidarity units founded in various enterprises differed in terms of action styles, while workers' communities differed in terms of the distribution of preferences for one or another ethos. The poles of our axis are "empirical types": we found two big enterprises which exemplified the two models. The relationship between these types of thinking and the actual styles in which Solidarity operated in those enterprises is indeed fascinating.

Clearly, these two ethos models represent two different interpretations of the function of religion and the Church in social life. In one of them, religion is the source of basic moral norms, and the Church is socially significant insofar as it advocates human rights. In the other, religion is a direct embodiment of basic values and the foundation of national values, while the Church cultivates national tradition and national raison d'état, though its role in championing universal human rights is not denied. Different though these approaches indeed are, they are not entirely divergent, and it is not impossible for them to negotiate a common ground. Undoubtedly, at that particular historical moment, the shared definition of the situation adopted by the Solidarity social movement members was incomparably more important than differences within the movement.

This overwhelmingly relevant common definition of the situation included the following key components: 1 ) the image of the previous social order and the sources of the crisis; 2 ) the vision of a desired social order and solutions to the crisis; 3) principles of social action. 


\section{Implementing the Ideal: Building the Independent Trade Union Autumn 1980: Definitions of the Social Situation}

\section{It Can't Go on Like This Anymore}

The definition of the social situation presented here was a long time in the making. In the foregoing, we pointed to its elements as gleaned from our respondents' statements and the meanings they attributed to actions undertaken back then. The symbolic catchphrases they produced aggregated into a coherent motivational framework and propelled a far-ranging process of social action. In the process, independent trade unions were founded and started developing. What we present here is a snapshot that captures an image which had essentially been processual until it took a definitive shape in the minds of the actors when they were asked to recount the turning point. Consequently, our snapshot is synthetic and schematic, yet it is certainly derived from the self-awareness of people who many months later were still involved in social action. Our account thus presents not so much people's actual views and states of mind in early September 1980 as rather what people believed these states of mind to have been while depicting them in hindsight.

The definition of the social situation is most succinctly expressed in a plain statement that persistently recurs in our data: "It can't go on like this anymore." This implies that people acutely recognised that the social situation was in crisis. The awareness of the economic crisis was situated in a broader context: that crisis seemed to people to be just a symptom of a far more general disintegration of social life. "The public want, it runs in the Poles' blood that there's more to life than simply chow, right?" said an activist of the factory trade-union unit (S 4, pp. 3-4). Another respondent tried to recount conversations at his enterprise days before the signing of the agreements in Gdansk and Szczecin. He told us that people had talked about poor supplies, a decline in agriculture, chaos in the economy, faulty accounting and management in the company (no matter how hard people worked, the profit they produced always disappeared), about not having any influence on decision-making and even not getting any information about the decisions made, about overstaffing in the administrative segment and hare-brained directives (cf. $S$ 64, pp. 9-10). In the interviews, the economic crisis is viewed as a social and political fact, and its descriptions yield a picture of social relationships and the rules of political action. Consequently, the economic crisis cannot be possibly separated from the social order and, as such, is discussed in terms of a crisis in trust for the Party and state leaders (S 76, p. 16). The gist of most interviews is encapsulated in an idea which is very simply worded by one worker-respondent: "It can't be so that 
the minority governs the majority." These words recognise and denounce the fact that social life is subordinated to the administration, which executes orders of the Party leadership. That life is dominated by the Party is reiterated by our respondents (cf. S 21, p. 35; S 38, p. 4). "Decision-making all top-down, everything prearranged in advance" (S 67a, p. 1). The monopolistic, socially uncontrolled power of the Party degenerated the executive apparatus (cf. S 22, p. 14; S 30, p. 18). Activists of the existing trade unions, the PUWP and youth organisations did not represent the interests of people and their organisations (cf. S 30, p. 19). In enterprises, the KSRs were subordinated to the management (cf. S 74, p. 2). Such a concentration of power in the hands of the Party and state leaders bred first of all stagnation and passivity, especially after 1976 (cf. S 38, p. 16); apathy and inertia ruled the day, for nobody felt like doing anything (cf. S 4, p. 8); what came to be referred to as silent meetings were a common fixture since people declined to speak on any issue in the belief that it was pointless anyway (Ibid.). People generally felt incapacitated and were paralysed by fear. Many of our respondents talk about how dangerous it was to voice any critique or to propose any change, be it the simplest one (cf. S 29, p. 5; S 3, pp. 7, 15; S 6, pp. 1, 14, 15; S 74, p. 7; S 39, pp. 6-8; S 4, p. 32).

Secondly, such circumstances engendered the feeling of humiliation and impaired people's self-dignity, all the more so that - thirdly - the power system blatantly breached the principles of social justice. As a result, workers and the clerical staff were disadvantaged both in living conditions and in the social potential. As regards the former, our interviews paint a dismal picture of workers' working conditions; and as regards the latter, our data show that people felt divested of any possibility, any right even, to influence their own lives.

At the same time, the power system produced a privileged group who revelled in luxury and were exempt from any social control. "Marx and Lenin, they wanted workers to have good lives, and not some caste of people, some ruling group" (S 30, p. 20). "People [...] couldn't speak out, they only call on us to work, and we've got nothing besides it - all decisions are made on top, nobody has any say on them" (R 67a, p. 1). Workers believed that their opinions were ignored in all questions, not only the economic issues, that "they've simply stop noticing workers at all" (S 3, p. 6). The management disregarded the workforce, and the cult of personality was ubiquitous (cf. S 74, p. 27). "They only went on bullying us," adds another respondent (S 36, p. 14). "Some people, it seemed to them that they had a total immunity" (S 3, p. 14). Somebody shouts: "Oh, the wilfulness of the management!" (S 74, p. 11), and other respondents add more epithets: autocrats (S 64, p. 32), red bourgeoisie (S 22, p. 15), new propertied class (S 66, p. 22), aristocratic lifestyle (S 37, p. 3), and similes: "no worse tyrant than a peasant turned into a lord" (S 74, p. 30). 
In the interviews with Solidarity activists and group interviews with workers, cultural disadvantage is also a salient theme. This involves complaints about limited access to education and cultural production as well as limited information on the developments in artistic, intellectual and cultural life. "For, my dear, my beloved, if we're talking privately," a worker says, "the government somehow failed to think of the urban transport, the drivers. They should know that in transport services there are not only such chaps who, indeed, only care about money and not at all about culture or education" (R 75, p. 6). "I want it, and we all do [...]," says another respondent, "we'll come to work... but let that work be like work should be. We, unfortunately, have to work, but we should have proper conditions so that our work isn't stressful, that we could work in peace, leave in peace and go home. Well, no, perhaps not directly home, but to a shop, to do shopping, and then go home, fix some dinner quickly, sit down with the child, play a bit, even read a newspaper, not at work, but at home. And go to the cinema. I haven't been to the cinema in three years, I guess. Well, I've got no time for it" (S 7, p. 8). Another respondent even counts impeded access to culture among the motives behind the protests in the summer of 1980: "People simply saw no other chance to improve their lives, their existence, work and generally everything that goes into human life, both work life and private life. No cultural development, educational development - just the opposite" (S 29, p. 24). Another respondent broadly discusses the political factor in barriers thwarting access to cultural production: "there're many people who don't watch TV, because there're also people who like to live like that: you come back from work, have dinner, watch TV, do your conjugal duty, go to bed, get up in the morning, day in day out. But look what people demand, abolishing censorship, it's not in order to lash out against somebody indiscriminately, because that's nonsense as well [...] But there're some historical facts that mustn't be hidden, mustn't be denied, mustn't be rigged. The same's true about culture as such; for it releases, well... in the nation, this impulse to work better. If you know that you'll go to the cinema and see, uncensored, Robotnicy'80, undoctored, you'll work more smoothly. That's my assumption. Or you'll see a good show on TV, or read a good book, or buy that book. There's more to life than chow [...] These factors that have been disregarded, they're factors, I believe, that strongly stimulate all employees to work. These cultural factors, exactly. That Miłosz ${ }^{54}$ guy got the Nobel Prize, true. And so what, who knew about it, who knew about him at all, well, who? And now the KOR can say: 'We promoted him.' [...] All independent bulletins that I've seen [...], all of

54 Czesław Miłosz won the Nobel Prize for Literature in 1980. (translator’s note) 
them wrote about Miłosz. Well, after all, it was a tremendous thing. There were some who knew. Putrament ${ }^{55}$ knew, for he'd studied with him in Vilnius, right? And he wrote something about him [Miłosz] once. But he wasn't talked about at all. Iwaszkiewicz ${ }^{56}$ would sometimes give him a go in Twórczość, and so what, Iwaszkiewicz was the way he was: neither hurting nor helping, the Iwaszkiewicz style, as people put it. But, boy, did it buoy people! When I heard about it [about Miłosz winning the Nobel Prize], I lost it completely, I called friends one by one, I was so happy. For I know who Miłosz is. [...] But plenty of people didn't know, did they? But they were uplifted anyway" (S 4, pp. 34-36).

For this reason, Solidarity trade-union units early engaged in cultural and educational work: "In Żoliborz, ${ }^{57}$ there's a Youth Culture Community Centre. They have discussion panels, but few people know about them. At this moment, we're working to arrange meetings with various people. At this moment, we're organising a meeting with Bratkowski, a journalist. Later, we'll try to hold a show for our company's workers. Perhaps we'll manage to invite as famous actors as Jan Pietrzak, maybe Himilsbach, perhaps, say, Jacek Fedorowicz, maybe actors who've been banned so far. How much of it we'll be able to do, we don't know yet. Certainly, if we pulled something like this off, more people besides the workers would come to such a meeting [...] But our idea is that our workers come first and invited guests second" (S 6, p. 22).

Impeded or almost blocked access to education and cultural production and, above all, severe restraints on what products of culture were made available to the general public were felt as an insult to human dignity.

Fourthly, the decisions made by the "privileged" caste, who lived off workers' labour, caused a deep economic crisis. Our respondents assess the bureaucratic apparatus as incompetent and irrational in the matters of economy (cf. S 22, p. $15 ; \mathrm{S} 76$, p. $16 ; \mathrm{S} 29$, p. 23 ) and claim that management was poorly organised (cf. S 30, p. 18; S 36, p. 3; S 74, p. 27), enterprises suffered from a faulty accounting system (cf. S 64, p. 8), Poland's economy was inherently wasteful (cf. S 66, p. 23), the government's decisions bred "economic absurdities" (cf. S 4, pp. 3, 33; S 6, p. 2), and foreign loans were squandered (cf. S 19a, p. 13). A respondent states: "We wanted to put an end to this rampant chaos" (S 7, p. 4). Another

55 Jerzy Putrament, a writer, publicist and politician, was a member of the Central Committee of the PUWP. (translator's note)

56 Jarosław Iwaszkiewicz, a poet, writer, essayist and translator, served at that time as the Editor-in-Chief of the literary monthly Twórczość and was the President of the Polish Writers' Union (Związek Literatów Polskich). (translator's note)

57 A borough in Warsaw. (translator's note) 
respondent concludes more generally: "We've had enough of that demagogy; mendacity and injustice must be put to an end" (S 38, p. 3).

The observation that the situation could no longer be condoned almost automatically prompted a very general change project. Democracy, in its broadest sense, was the key slogan, and its applications ranged from political governance to relationships at the workplace. Our respondents insist that the inordinate number of regulations (most of them defying common sense) must be trimmed down, and the government's actions must be subjected to social control at all levels (state, region and enterprise). One respondent states that Social Control Committees should be established and demands freedom of public expression and the transparency of state documents (economic policy projects, statistics, etc.), at the same time saying that "the PUWP may remain the nation's leading force, but it can't govern the country. The country should be governed by workers and peasants under a socialist system" (S 64, p. 34). "The Party can define general goals but in consultation with society. The Party shouldn't make economic decisions. And the Sejm ${ }^{58}$ and national councils should have their competences enlarged" (cf. Ibid., p. 32-34). This very detailed statement summarises the basic political demands and outlines the envisioned restructuring of society. "We must personally participate in decision-making that concerns us" (R 67a, p. 4), the country and state cannot be governed without workers (S 3, p. 6), and "we must all know more about what's going on in Poland" (R 67a, p. 4). The demand of social control over various governmental agencies is restated time and again (cf. S 30, p. 22; S 21, p. 35; S 6-4, p. 32), social consultation is demanded in decision-making processes (cf. S 3, pp. 30, 34), and democracy is addressed as a condition of political competition (cf. S 66, p. 24).

Freedom of expression is framed as a key value, invariably accompanying the demand of democracy (cf. S 29, p. 29; S 20, p. 24; S 4, pp. 3-4; S 6, pp. 1, 15; S 3 , p. $8 ;$ S 37, p. 19). Other demands include restoring the rule of law, subjecting the Party and administration apparatus to law and observing the separation of powers and their respective independence (cf. S 22, p. 17; S 30, p. 22; S 37, p. 19). The last item in this list concerns abolishing factional privileges which cause social opportunities and living conditions to be lopsided (cf. S 30, p. 15; S 66, p. 22).

58 Sejm refers here to the Polish parliament, which was a one-chamber body in the period. Historically, before the Second World War, the Sejm was the lower house, while the Senat (English: Senate) was the upper house of Poland's parliament. This structure of the country's supreme legislative organ was reinstated in 1989. (translator's note) 
Many of our respondents also demand incisive economic reforms. Such reforms should include the decentralisation of the management system (cf. S 29, p. 29), a greater autonomy for enterprises (cf. Ibid., p. 30), a reorganisation of economic and political management (cf. S 66, p. 24), the development of private farming, making enterprises profitable, curbing the expansion of heavy industry and the promotion of technical development and innovativeness (cf. S 4, p. 34).

Democratisation is defined as the establishment of a social order in which people can genuinely participate in decision-making concerning their lives. This seems to have lain at the core of society's aspirations. "Workers, as workers, should feel they are co-managers of their enterprise and have a say in decisions about the economy. Workers, as citizens, together with other strata and groups, should have a right to participate in government's decision-making concerning society. Poles, as society and nation, must have a right to manage their own lives. We want to know more about everything that is going on in Poland [...], at this moment, I guess, we all have faith in what will happen in the enterprise or in Poland, for this concerns all of us. We'll all be in this together" (R 67a, p. 4).

This was the backdrop against which the role of Solidarity was defined. The trade union's organisational principles and its operative modes were a vast experiment. In our respondents' relations, Solidarity resembles a grand game people played with themselves and each other in order to live up to their ideals in everyday action and to prevent this wonderful, beloved "child" from disappointing the faith they had in it. "While demanding the implementation of the democratic ideal in entire society and in the state, we must live up to this ideal in our independent trade-union unit. Even at this early stage of the development of the social movement, people were clearly aware that the NSZZ 'Solidarity' was a guarantor of social change. But to perform this function, Solidarity itself must be a democratic institution. Solidarity teaches democracy" - this is a verbatim quote from our interviews (S 76, p. 6; S 43, pp. 12, 17; S 64, p. 28).

The emergent trade union's major achievement was that it reaffirmed people's belief that they could actively influence their own lives and the fate of their group. "People finally came to believe that they didn't have to wait for anybody to tell them what to do and then do as they were told" (S 64, p. 23). "People grew more confident and convinced that they were able to act of their own accord, without orders from the Party and administration apparatus" (S 29, p. 5). Grassroots initiatives are frequently emphasised: "Wherever any grassroots ideas appear, we do our best to entrust these issues to the proponent immediately, to the one who came up with the idea, and I must say these people go about these things very efficiently" (S 22, p. 7). The principle of agency of organisation members is confirmed: "The point's not to wait for instructions" (S 6, p. 25). 
Sometimes difficulties appeared in developing the trade union, because workers tended to expect "somebody to come and explain things in more detail" (S 67a, p. 5). Certain basic rules had to be observed in order to encourage people's active commitment. One of the rules was transparency, i.e. clear information about what the trade union was all about (cf. S 22, p. 10; S 76, p. 9, 10; S 43, p. 6; S 20, p. 23; S 66, p. 30). One respondent says that PUWP members in his enterprise envy Solidarity complete and transparent information (cf. S 25, p. 6).

Another rule concerned the elimination of the command-structure from the trade union. Our respondents stress, for example, that decisions made at the organisation's lower level could not be revoked at an upper level (cf. S 76, p. 13), the union leaders were controlled by the members (cf. S 30, p. 14) and, crucially, decision making was not arbitrary but involved all the interested parties (S 4, p. 30). These principles are pithily captured by an activist who explains the rule to call strike only if a poll among the workforce backed it: "[Solidarity's] factory committee cannot issue any decisions all by itself" (cf. S 64, p. 21).

Our respondents point out that Solidarity's democratic style was vitally based on democratic elections and believe that the trade union could indeed express the interests of its members only if its activists were genuine representatives of the membership (cf. S 20, pp. 16-18). In one interview, the respondent analyses organisational missteps and addresses the democracy vs. autocracy conflict which surfaced when a person appointed chairman of the union's factory committee started to rule autocratically, disregarding the opinion of the commission and the board. The respondent recounts a complicated process in which the chairman was removed from office and voices dilemmas encountered when implementing the rules of the newly established trade-union unit. "For people should be given a chance, you just can't destroy new bonds bred by the very fact that the organisation has come into being" (S 20, pp. 22, 23). The same respondent also stresses that truly democratic action arises from a difference of opinions. Conflicts do not harm democracy (cf. Ibid., p. 27). The respondent reports how the Factory Committee, which had evolved from the NSZZ "Solidarity" Founding Committee, "viewed itself as an interim body and in order to feel a genuine and legitimate trade-union agency, a new, fully democratic election to the Praesidium of the Committee and the Board was called" (Ibid., pp. 16-17). In our respondents' view plurality is the basis of democracy (cf. S 3, p. 13).

The fundamental aim that united individual people and groups was building an organisation independent of the state and the PUWP. This ambition must have been exceeded if what started as a popular mobilisation for building a new organisation mutated unbelievably fast into a huge movement for social reforms. 
Important elements of the definition of the situation fostered a new social consensus. It is no coincidence that the reasons behind the social crisis mentioned above were also cited by the leaders of PUWP organisations we interviewed.

Our data include interviews with the secretaries of PUWP basic organisation in small enterprises and with the secretaries of PUWP Committees in bigger enterprises (originally, we had planned to interview first secretaries, but as already explained, some of them declined the invitation and referred us to their deputies). Their definition of the situation overlaps in essential aspects with the definition outlined above. At the same time, it differs from the definition formulated by the directors and the members of the old (branch) trade unions. Below we compare the portrayals painted by the representatives of various organisations.

\section{The Public Must Understand}

Their fundamental similarity is that the crisis is blamed on the centralised power system. This is a very important observation, pointing to a crisis within the PUWP itself. Undemocratic ways, decisions flouting social interests and the fact that even Party activists had little possibility to influence the leaders' decisions and criticise their policies are listed as the causes of the social crisis. "The crisis arose because there was no control over decision-makers and, additionally, wise people were not listened to" (P 1, p. 16). "Gigantomania prevailed, domestic technology and inventions weren't used, but everything was based on licences from abroad, and mistakes were made buying and implementing those, the crisis in the world's economy wasn't taken into account" (cf. P 2, p. 19). "Inane, command-based management and faulty decisions made at the central level were explained by objective reasons such as the weather. Such babble from the highest ranks of the PUWP makes one laugh" (P 9, p. 2).

The definition of the situation as formulated by the Party functionaries made them demand a renewal. The renewal was comprehended primarily as the democratisation of both the PUWP and social life. The views of the enterpriselevel Party functionaries are at their clearest in their assessment of the renewal process. After four or five months, they assessed it more critically than ordinary Party activists did. This was undoubtedly caused by the identification of the former with their organisation. The demand of calling an extraordinary congress of the PUWP as quickly as possible was voiced time and again; this was the axis around which the functionaries' expectations revolved (cf. P 4, p. 15; P 48, p. 13). Another typical element of the Party functionaries' attitude was that they insisted on calling the Party and state leaders to account relatively more emphatically 
than the activists of the newly formed union did. "The renewal can't happen with the old people in the lead" (P 9, p. 15), "the renewal hasn't reached everybody" (P 48, p. 13), "the Central Committee should change more thoroughly" (cf. P 17, p. 2), "the tainted ones must be punished" (P 40, pp. 13, 14, 17).

"The renewal itself is superficial, this process of renewal is too sluggish, I guess; the guilty ones haven't been called to account consistently, there's not concrete agenda for the Party or economic policy" (cf. P 9, p. 14). "Despite the renewal nothing has changed, and again there's no information about what the Central Committee is doing" (cf. P 17, p. 3).

The demand to democratise the PUWP was repeated time and again: "The party organisations can't have everything imposed on them from the top, because things will continue the way they've been so far" (cf. P 17, p. 2). "Party activists and organisations must be autonomous" (cf. P 40, p. 15). "Party members shouldn't be afraid to say what they think; the Party must be urged to operate in transparent ways and allow open discussions" (cf. P 17, p. 2). The reform agenda proposed by the respondents included the decentralisation of management, the economy based on sound profit-loss calculation, self-management for enterprises and self-government territorial divisions, independent decision-making (only strategic decisions should be made centrally while local matters should be decided locally), a reduction of investments and the promotion of agriculture (cf. P 2, p. 24). As can be seen, both the language and the substance of the Party functionaries' agenda differ from the general definition of the situation. Their language is more technical and economy-focused than the language of trade unionists and workers.

Many Party activists clearly embrace the workers' protests and are committed to the reform process they initiated. Sometimes they talk about it directly: "the strike was a very unpleasant event because the workers did what I'd also have done" (P 9, p. 3). Another enterprise-level Party secretary confesses that he contributed to establishing the Founding Committee of the new trade union unit by calling together activists from the company's various departments and letting them hold their meeting in his office.

Two attitudes can be distinguished in the interviews with the Party functionaries. In one of them, the social protest is regarded as justified, and a possibility is envisaged to democratise both the PUWP and the entire social system. The functionaries commit to the reformatory process without forfeiting their identities as PUWP members. As such, they believe it possible to reconcile their own interests with society's interests.

The other attitude is radically different. Some Party functionaries are highly distrustful of and feel threatened by the organisers of the independent trade 
union. These functionaries identify more closely with the bureaucratic apparatus. They deem their interests jeopardised. Tellingly, they harbour a certain resentment: they insist repeatedly that PUWP activists have made identical or similar demands for years, but nobody has heeded them (cf. P 1, p. 4; P 2, p. 15; P 9, p. 1). Consequently, they tend to be critical of the Party and state leaders.

The Party functionaries do not express the views which we referred to above as a conspiracy version of history. They have no doubts that the mass social protest is a spontaneous movement. Regardless of how respective PUWP secretaries judge the events, they are not inclined to believe that the developments were provoked or manipulated by a group of politicians in quest for power. This is the reason why the old Party activists try to get involved in the establishment of new trade unions. As a rule, they rely on help from their company managements; hence such trade unions come to be colloquially referred to as "directorial." We shall address them in more detail in the following.

Some functionaries distinguish between right and unwarranted demands made by the protesters. Consequently, they tend to point their finger at troublemakers, i.e. those who push the protest in a wrong direction. Briefly, they set apart the good from the bad, thereby reducing a rich array of nuanced attitudes to a black-and-white model. These secretaries state that the majority are good, but there is a bad minority.

What the Party must do now is regain society's trust. This goes hand in hand with insistence that the government must also recover public trust. This is by no means a coincidence. The Party functionaries think in terms of the political system. In their interviews, they eloquently talk about efforts to incorporate the emerging trade unions, and emphatically "Solidarity," into the existing political system. They explain that trade unions must collaborate with each other and organisations must be established which could bring together representatives of all social and political organisations. Asked what line of action the old trade unions should follow, one secretary answers: "First of all, they should find ways to cooperate with the new unionist movement. To prevent a general disintegration of the unionist movement and the working class. For such a risk is there" (P 15, p. 16). Asked "what should be the function of trade unions?" the secretaries tend to answer: "Well, they must co-manage the enterprise and be co-responsible for it, because they're not only subordinate, not only controlled, but they should also feel $[\ldots]$ responsible for the enterprise, together with the board, with all the bodies" (P 40, p. 7). Asked about Solidarity's cooperation with the old union, they say: “There's collaboration, they've even invited the leader of the old unions to relocate to that bureau of Solidarity. Of course, they [the old trade unions] collaborate because they have more experience perhaps, and every 
new organisation - it must take its time, right, until it sees for itself what all these problems are about ..." (Ibid., p. 9). "But generally we want one trade union, and our basic assumption is that all trade unions work for the sake of the people [...]. To have one trade union would simply be better, for there'd be fewer people delegated away, fewer people to make decisions, and the factory would have an authentic representation" (P 9, p. 12).

"Solidarity did tackle such issues, and it must be said, that it was in close collaboration with the department's management; in collectives [...], where, let's say, the collective must decide, there're in them [...] representatives of the old Council, but also representatives of Solidarity, who all the time take part in all these matters" (P 1, p. 13). "So far, they've been coming over, generally [...], I talked to the director, and we decided: let them come, the Solidarity guys, and let them see that decision making isn't a piece of cake. Let them simply learn. And they can finally see that the collectives, quite wisely and reasonably, make decisions for the good of the workers and the company, not the way some of them thought" (P 32, p. 6, 7). The same secretary confesses: "Of course, I kept telling them [members of the Branch Trade Union Factory Council], persuading them to collaborate with that Solidarity. My point was, of course, to appease that aggressiveness of Solidarity, to eliminate those activists that use Solidarity not for the unionist work but for the dealings at odds with our interests here, Poland's interests generally, right $[\ldots]$. I'd like trade unions to collaborate together, to cooperate for the sake of the workers and the enterprise and, of course, with the Party organisation, and I'm sure it'll come to pass" (Ibid., pp. 11, 13). "No one from the management or the Party organisation does anything to provoke any antagonisms [...]. At this moment, we have a broad idea of what's customarily called the directors' council, besides the directors, the council also includes the Party organisation secretary, representatives of all the trade unions and representatives of the youth. And all the key decisions are made by them. All the existing organisations have their say. [Interviewer: 'And does what Solidarity says matter?']. Of course. It matters and makes sense" (P 101, p. 6, 7). "I consider one thing to be most important $[\ldots]$. Everybody must find their own place $[\ldots]$ in the current situation. As time goes by, things should somehow get adjusted and cooperate $[\ldots]$, in order to have unanimity, because I believe that in such circumstances we won't have unanimity, and it'd be bad for us not to be unanimous, but of course, the clash of opinions, of attitudes, as we know, is part of progress" (P 2, p. 18). One of the secretaries quoted above says: "We've adopted and followed all the time this line of action - to keep the workforce as closely united as possible. And this, I guess, should be a goal for our country. To keep the nation united. This is, I guess, the most important thing. Everything can be 
achieved, riding this renewal wave, if the nation is united, in peace, if it's possible to work normally and keep things normal" (P 15, p. 15).

Clearly, we are faced with a complex situation: on the one hand, collaboration and unity are an important goal while, on the other, differences of opinions and attitudes are acknowledged as a precondition of progress. The basic dilemma of the PUWP secretaries is how the national unity can be maintained, while allowing free debate and independent trade unions. Importantly, all the interviewees emphasise that the Party organisations within their enterprises do not interfere with the operations of trade unions. "I can't influence, I mean, I did influence the old trade unions, because there's a bond of sorts with the old trade unions though they're independent. But even in contact with the old ones, I always proceeded very cautiously because they were also afraid to be suspected of being steered by the Party's committee" (P 32, p. 11). This entails a meaningful change in how the Party organisations work. They cannot directly command and need to solicit support for their ideas by sound argumentation rather than by "bossing around." This means that they can only impact the events by using subtler methods and building a favourable self-image.

For the supporters of reforms, it also means something else: people's opinions must genuinely be taken into account. The renewal thus requires adopting a new way of thinking ( $\mathrm{P}$ 101, p. 11). This is a serious challenge, for it demands surrendering the privileged position: "Well, what should be done, what measures should be used? First of all, listen, listen to advice of smart people, keep directly in touch with the workers, listen to their often, though perhaps not always, what do you call them, well, caustic remarks, often unpleasant, but sending you on the right track and, you could say, to people's often very healthy and apt words" (P 1, p. 16). " [...] what good would it do to try and influence the staff and, right, coerce people and whatnot, if Solidarity's won popularity [...], what the representatives of one side and the other say is equally taken into account and given a thought in the current situation, which wasn't the case before, this is about taking the working class into account, that's how I'd put it, the government reckons more with what the working class say now" (P 40, p. 4, 17). "If you work, you want your work to matter, to be recognised, and not just to be a workhorse and only follow the orders" (P 60, p. 22).

The Party secretaries are satisfied with the way the social conflict has been solved: "[...] we're and have been a highly tolerant country, uncommonly progressive in all respects. Even what's going on in our system now is uncommonly progressive, I mean in the country. It's unthinkable anywhere else, but we managed to have both, one side and the other come to terms, as we've come to terms on one fundamental matter, so people have also come to terms, right. That's it" 
(Ibid., p. 12). "It seems to me that it's a good thing that this has been finally solved in this way and not another, which was often used in the past, and that we all, exactly we all have finally lived up, so to speak, to the task and come to terms with each other, because it seems to me that solving conflicts is not about using violence and force, but about candidly coming to terms. And it seems to me that this is the only possible way to go there is" (P 1, p. 14). "I believe, sense prevailed on both sides, and it made it easier to reach an agreement on all issues" (P 2, p. 5). Asked "How do you assess the way the social conflict has been solved so far?" the interviewees answered: "You mean that the new unionist movement has been kind of legalised? Absolutely correct. It was necessary, I guess, and it should've happened earlier than it did. The atmosphere in enterprises would be far healthier" (P 15, p. 14). "Well, finally somebody drew conclusions from the sorry events. Finally solving this meant talking and reaching an agreement. But it needs to be said that this period was very, very painful for everybody. Painful and tense" (P 101, p. 10-11). "I'm fully convinced that it's the only method. The method of concession, I call them clearly a concession - the agreements. Because some items included in these agreements are simply unrealistic, but they've been signed $[\ldots]$, for example, right, the agreements say - and it's only one example, many more could be found - that you'll wait five years to get a flat. But both sides knew it's absurd, that it can't be done right away. Getting there will take long years of struggle [...] But, I repeat, they were concessions. And these concessions had to be made. There was no other choice" (P 32, p. 15, 16).

"Well, it seems to me the reactions were divided. Well, some considered it [allowing an independent union movement in the accords] a failure of sorts, [...] because they weren't listened to, well some voices weren't, this happened... And that's what they considered [...] a failure, but, finally, most of those who ... this department council [...], most of them also joined the new unions" (P 1, p. 10).

The last utterances in this series clearly show that the PUWP secretaries differ in their assessment of the accords. Some of them seem to identify more with the reform process and to endorse the fundamental values articulated in the social protest. Others regard the agreement as a necessity but view it as a concession on the part of the government. Both positively assess the signing of the accords and solving social conflicts by discussions and negotiations, yet their aim is to integrate the new movement with the existing socio-political system. Despite clear differences, the PUWP secretaries share a common vision of the situation.

Firstly, the protest of the Coast workers fully expressed workers' actual interests. But in most interviews, the secretaries claim that the workers' demands were similar to the initiatives of the Party organisations and state that Party members firmly supported the protest, participated in the strikes and joined 
the Solidarity union movement despite initial distrust. "But liberty, freedom of choice, be my guest, and we were even open in our Party meetings that the comrades had the right to choose a union [...], there was no campaigning to stop anybody joining [...], but we declared everywhere and always that, comrades, we leave the free choice to the comrades, no hard feelings, but take care, comrades, not to change your colours ${ }^{59}$ in this new union" (P 32, p. 4), says a secretary who defends the existing social order in his interview.

On the whole, the social demands and political activity of the Solidarity trade-union movement are assessed in positive terms. "I believe they want to take care of a lot of things, and perhaps they don't exactly know how it works because, whatever you might think, well, you can't have everything done all at once and start doing things entirely differently. In the enterprise, you go about it, clearly, step by step. Anyway, they want, in my opinion, to do the right thing. And, I think, we'll eventually reach an understanding in all matters" (P 15, p. 10).

Secondly, the PUWP secretaries are optimistic about reaching an agreement with Solidarity, which they perceive as a powerful mobilising force, highly relevant to combating the crisis. "To put it briefly, I believe that it'll have a very positive influence, we needed something like that" (Ibid., p. 16). "They [Solidarity] are, after all, an authentic force and not only in our enterprise. We realise this and would like [trade unions] to take care of the affairs of the enterprise, of the workers [...]. It [this force] will be helpful because it's, I believe, it's a new, healthy force siding with which you can do much more - honestly - that much more can be done than with the old unions. Because, it's new, vigorous, enthusiastic, full of expectations and recognised as important" (P 32, p. 5). "But one thing is good, I mean that we - at least the Committee, the management - hope that because people join the Solidarity union spontaneously and think of this union as their own union, we all shall or we'll all be able to muster as much good will as possible to improve the economic condition of the factory, and not only of the factory; secondly, to contribute to more rhythmical production, and third - well, it's always true that if people want something and it appears spontaneously in such and not any other circumstances, just as the Solidarity union has just appeared, you hold out much hope that if you propose something good for the factory, the

59 The admonition not to "change the colours" is doubly meaningful in this context, as one of the central symbols of communism was the red colour, and hence members of the PUWP were popularly called the "reds" in Poland. The insistence on not changing the colours - not losing the "red" colour - boils down to reminding people that they should remain loyal to the party and follow the party line. 
country or Warsaw, this will be supported and implemented. I remember the early 70s, when the secretary also appealed for help and all people appealed too, irrespective of the Party or social membership. They helped and were let down, and in connection with this I think that, as concerns this matter at hand and the establishment of these trade unions, it won't be wasted but it'll serve us all" (P 9, p. 12, 13).

Thirdly, the secretaries notice that the system must be changed. "Generally, everybody agrees that the system can go on only if the structures are made more flexible, and greater freedom is given to people and to the units of the political and economic apparatus. [...] certainly, these transformations that took place in, as they say, the hot summer of 1980 , well, should produce a certain institutional framework, some guarantees that such a bumpy ride won't happen again" (P 2, p. 20). First and foremost, trust in the authorities must be restored. This means that law must be observed, the signed accords must be abided by, the obligations incurred must be kept, and the compromised leaders must be called to account. "People know that our representatives have let us down, this is a uniform view, that they should be made more accountable [...], some were called to account at the $8^{\text {th }}$ Plenum, right, that some people should be called to account" (P 40, p. 12). Besides: "The genuine and not only declarative role of self-management in enterprises, in villages, in cooperatives should be restored" (P 2, p. 20). Further: "The decision-making competences should be divided a bit. There're strategic decisions [...], but there're also decisions that needn't be made centrally but should be delegated to the lower levels of administration. [...] It'll mean decentralisation and likely a democratisation of, I'd say, overall social action [...], we need to continue this renewal process; it's an ongoing process, I believe $[\ldots]$ the structures must be constantly improved, it mustn't be a stiff organism, but a fluid organism, always in motion, for we know that it is life that changes conditions, and people must adjust to these conditions" (Ibid., pp. 20, 21). "We admonish, we want, let's say, the Constitution to be respected, and law, let's say, to be law" (P 60, p. 1).

Making the political structures more flexible is down to three basic factors: 1) the division of competences and the clear demarcation of the decision-making spheres of the system's respective powers (PUWP's Central Committee, parliament, government); 2) institutional forms of social control (Solidarity); and 3) democratic changes within the PUWP. The secretaries cautiously allude to the separation of powers. That the state's institutions must be subject to society's control is stressed even by not very democratically minded secretaries. Our respondents differ on what specific political reforms should be launched. Many of them believe that reforms should boil down to making the systemic principles 
which are already inscribed in the Constitution of the People's Republic of Poland a reality in actual social practice. Others insist that changes must be more profound. The solution they envisage is holding a congress of the PUWP in order to develop a clear agenda which will give the social interests and aspirations a desired "institutional framework."

The PUWP secretaries tend to have a binary vision of trade-union movement activists. "There're good and bad people in Solidarity, both in enterprises and in the National Commission. Let's say there're more liberal factions, radicals, etc., as in any other large group of people; at X, there're also very different attitudes - calm people, and more impulsive people - related to their personalities, experiences and, let's say, employment in this enterprise, right, and age" (P 2, p. 18). "On the whole, you could say that they're in the process of organising [...], not really consolidated yet because they simply haven't elected their basic bodies yet and all they do is, I'd say, relatively fluid [...]. Generally, I've no problem with that, but it seems to me that there're various nuances and various, well, yes [...] groups [...], yes, individuals. Well, not individuals, but some, some groups, nuances which, it seems to me, are not always helpful but often, often even harmful to that whole movement" (P 1, p. 19). "All new things produce their own problems, and the way it happens is that many people have joined this union quite randomly, and many people'll likely stop - that's what I think, and I don't know whether that's right - when they have their election campaign, will stop functioning as committees... I think a moment'll come when that union achieves stability, in organisation and in agenda, and then they'll start working properly [...] I don't like it... I mean, it seems to me that the leaders aren't united [...] I don't like it, it's the most important thing, I don't know whether I have a right not to like it, but that's my opinion that the Solidarity leaders at the national level have no control of the situation [...] It's highly disquieting [...], I guess the regional Solidarity centres are to blame for this, for they don't shrink from such things against the leaders or without letting the leaders know, and in this way they stir that chaos or disquiet in the country" (P 9, p. 10,15). This idea is fully articulated by one of the secretaries: "But Solidarity must first of all focus on the union-related matters. They can't go beyond their statute. [Interviewer: 'And what do you regard as non-union activity?']. It's political activity they've engaged in so far, even before the $8^{\text {th }}$ Plenum. Narożny [the respondent means Jan Narożniak ${ }^{60}$ is arrested - a

60 Jan Narożniak, an oppositionist, samizdat publisher and Solidarity member, disseminated the Attorney General's confidential instruction on "prosecuting antisocialist activity" and was arrested in November 1980 for revealing state secrets. (translator's note) 
flyer campaign starts; the Warsaw Party Organisation legally elects [...] comrade Kociołek $^{61}$ - a flyer campaign starts, a protest starts. [Interviewer: 'Well, yes, but you know why actually...']. But it's our business, the Party's business, not theirs. [Interviewer: 'Well, if the Party is the governing power, it's also their business in a way.']. Yes, but not in this way, not [saying] that he's guilty of crimes against humanity, excuse me. He's the boss of my organisation. Is it a proper way to go about it? And I don't even mention... But there's no political culture in this fight, is there? [...] It's not defence of the union, I mean: defend it, but not at all cost, I said, there are some limits. When you breach the order of things, the legal order in this case, well it's not the way to go about it, I guess; the state is our supreme cause, the order of the state, and not this or that man-unionist, if he violated this order" (P 32, p. 8). These words express the anti-democratic attitude of some enterprise-level Party functionaries. The state is defined as superior to society, i.e. not as an institution that promotes social interests, but as a power which is independent of society and delimits social aspirations.

The limit to social demands was another axis around which the thinking of the PUWP secretaries revolved.

Their thinking essentially negotiated between the acknowledgment of the rightfulness of social demands which should be incorporated within the system, on the one hand, and the imperative to sustain the socio-political status quo, on the other. Importantly, already at this early stage, Solidarity activists also thought along tolerably similar lines. This may be why, even if the Party functionaries negatively assess some of Solidarity's practices, they conclude that political judgment indeed prevails among the unionists. Even the most anti-democratic PUWP secretaries observe that the situation is beginning to level out. Some of the secretaries point out that the $7^{\text {th }}$ Plenum of the PUWP's Central Committee was instrumental in bringing about stabilisation and "assuaging" Solidarity. They insist that, while participating in decision-making about the matters of importance to working people, Solidarity must accept the existing limitations. According to our respondent, the union's activists were inclined to acknowledge these limits (cf. P 32, p. 18). All the secretaries whom we interviewed subscribe to this opinion. Half a year after the signing of the accords in Gdansk and Szczecin, they believe it is possible to collaborate with Solidarity. "A working consensus" has been achieved.

61 Stanisław Kociołek, a politician and PUWP functionary, was Deputy Prime Minister in December 1970, when the Tri-City's shipworkers went on strike. He was an accessory to a brutal crackdown on the strikers that left many of them dead. (translator's note) 
"[...] people on these boards seem to have hit it off, I guess. People you can really discuss things with. But I say that sometimes even two or three meetings of one commission produce no results for a given set of problems. Yet in the following meetings, we reach an agreement for the sake of the workforce and the enterprise. You could say the situation has settled down" (P 101, p. 5).

This is the context for the negative assessments of the government, as mentioned above: "They should've arranged some earlier negotiations and developed a line of action based on the Gdansk agreement between the government and Solidarity, and others too, in order to prevent what's been going on till now. It's very irritating and upsetting, too" (P 15, p. 15). At the same time, the Party secretaries accuse the workforce of their enterprises of bickering, sluggishness (P 101, p. 9) and anarchy (P 32, pp. 12, 14). They believe that the basic outline of the new "institutional framework" has already been established, and now the decisions made so far should be implemented as quickly as possible; it is time to get round to the toilsome work of overcoming the crisis: "The beginnings were very good, as regards Solidarity [...] at this moment, perhaps, in my opinion, there're too many strikes, yes, in various regions, if the state has no funds from which to give anything more $[. .$.$] , the public should under-$ stand, and I believe that knowing perfectly well what situation the country is in, they shouldn't make any more trouble, but they [the union] should somehow together..." (P 40, pp. 16, 18). According to the PUWP secretaries, society must understand that the process of change is, exactly, a process and the demands, no matter how well-founded, can only be met incrementally. The Party secretaries evoke the national values as an essential plane where an understanding can be reached and the basis for the historical compromise. "As far as the tradeunion movement is concerned [...], well, it is, I guess, a new factor, an unprecedented one [...] in the history of the People's Republic of Poland, and it must be said it'll likely be a permanent factor. Solidarity itself is bound to evolve, too, but, obviously, we need to adapt, and Solidarity, as well, and entire society to the new conditions, to the new realities; first of all, we must all feel we're Poles and only secondarily members of the union or the Party, or other, right, citizens; that's I guess the most important thing, the cause of Poland's raison d'état" (P 2, p. 21).

The upswing of social ambitions, on the one hand, and delays in implementing the decisions, on the other, clearly upset the enterprise-level Party secretaries.

Some of them embraced the reform process and were more critical about the government, whereas others were anti-democratic and emphasised the proliferation of "unfounded" social demands. Despite that, the situation in Warsaw's enterprises undoubtedly levelled out at the turn of 1980 . Hence, the secretaries 
optimistically believed that both sides would play by the new rules of social game and that this was the best solution for the entire country.

\section{"Somebody Must Be in Charge of the Whole Thing"}

The leaders of the old unions (this is how we referred to the entrenched branch trade unions during our study as different from the arising Solidarity trade-union units and from the autonomous, so-called directorial trade unions) found themselves in a far worse situation than the Party functionaries. Even though most of them were PUWP members, they primarily identified themselves as union activists. The renewal slogan brandished by the PUWP leadership corresponded (declaratively at least) to the social demands, which reaffirmed derogatory opinions about the existing trade unions and, consequently, induced very strong emotions. The interviews with the old union activists, who feel betrayed and vulnerable in the new circumstances, ooze anger and resentment against both the PUWP and ex-members of the old trade unions. Even though they openly hate quick-rising Solidarity, they cannot disagree, much like PUWP functionaries, with its assessment of the social situation: "the demands were right" (B 31, p. 5); "The Coast makes demand for us all; all working people have benefitted" (B 61, p. 7). Nevertheless, more often than not, they voice emotionally charged reservations. "I highly value what they do," an activist of the old trade unions evaluates Solidarity's work, "but I wouldn't be able to declare to join them" (B 28, p. 8). This attitude underlies the definition of the situation as professed by the branch trade-union activists. The definition was formulated in relation to the developing Solidarity. The respondents articulate a basic belief that the proposals which the activists of branch trade unions had been putting forward for years, in particular since 1976, didn't differ at all from Solidarity's demands. Even the demands of the Coast strikers were no different from those of the old trade unions (B 41, p. 3; B 26, p. 5). This belief produces a rather deprecating image of the new trade union: "To me, Solidarity in Gdansk resembled the CRZZ, a slightly different version of it perhaps; it would be the same, at a certain moment that Wałęsa would ... well, exercise power through his committee over all the unions in Poland, and, obviously, there's discipline, and because of it everybody will be doing as they did before" (B 8, p. 6). "Solidarity is another CRZZ," adds the same respondent (Ibid., p. 10). "Like any other organisation, Solidarity will be managed top-down" (B 62, p. 15). They also express a negative opinion about Solidarity: “They organise strikes without the proper recommendation from Solidarity's Main Board [sic!], so it seems to me that there was no order and no agreement with that Main Board of Solidarity, but people just did what 
they wanted at random and that organisation was a mess" (B 28, p. 10). Another belief is that Solidarity is not consistent about calling the previous state leadership to account (cf. Ibid., p. 10). Censure of the Gierek cabinet is an integral factor in how the branch trade unionists define the situation: "They're to blame, they must be punished, why should we, honest trade union activists, bear the consequences?" They seem to cry: "We are scapegoats" (cf. Ibid., p. 6).

The old trade-unionists believe that the trade unions failed in their social roles because of the CRZZ coterie (cf. B 41, p. 7), which meekly surrendered to the PUWP; the fact that CRZZ members were at the same time members of the PUWP's Central Committee severely restrained the old trade unions' efforts (cf. B 37, p. 3; B 31, p. 19; B 62, p. 9). The trade unions were subordinated to the Party (B 28, p. 7), and elections to the Enterprise Council were decisively influenced by the PUWP executive (cf. B 46, pp. 1, 2). Our respondents also complain that the leadership of the trade unions never seemed to change: "Everybody believed that if one got that function, one would always have it" (B 34, p. 13). "Whoever held any position, they were Party members. [...] When a top-down order came from, let's say, a Party body, did a Party member disobey? No, they didn't' (B 28, p. 13). Our respondents also mention a lack of control (cf. B 31, p. 14) and the direct subordination of the trade unions to the clerical segment (cf. B 31, p. 18; B 61, p. 1; B 62, p. 1). "We talked too much about achievements and too little about difficulties" (B 34, p. 6). At the same time, nearly all respondents claim that Enterprise Councils passed the members' demands to the CRZZ, but to no avail (cf. Ibid., p. 3), and complain that the trade unions were impeded by bureaucracy and the centralised management system (cf. B 31, p. 5). "Bottom-up demands, people's demands were, well, brushed off" (B 34, p. 4). "Activists couldn't persuade their leaders to mind people's grievances, what they talked about" (B 26, p. 14). "The top-down steering method was inadequate" (B 31, p. 7), but that's why "those on top are to blame" (B 31, p. 11).

As can be seen, the definition of the situation was constructed in reference to the image of the organisation, and the situation at hand was almost exclusively perceived in terms of the collapse of the old trade unions and their activists' sense of threat. More general assessments are rather scarce and shallow. Among the reasons behind the crisis, our respondents list ill-advised investments and trade based on unequal terms (cf. B 34, p. 13), incompetent management, corruption, thievery, a lack of planning in the allegedly centrally planned economy (cf. B 31, p. 8), aggravation of social inequalities (cf. B 46, p. 6), low wages, difficult working conditions and a poor organisation of labour (cf. B 34, p. 5).

This resentment-inflected definition stretches between hatred of the former leaders and rancour against the membership, whom the activists accuse of 
abandoning them en masse: "plenty of people upset us in a way, for they left in spite of what we've done for them" (Ibid., p. 7); "people don't appreciate the effort of the Enterprise Council, this ingratitude hurts [...] And, after all, we did our best for them" (B 61, p. 8, 5); "the Enterprise Council has always been people's tacit friend" (B 62, p. 2).

But, even when seemingly expressing the essence of the social protest and agreeing with "people" about the causes of the crisis, "people's tacit friend" turns out to represent fundamentally different values and interests than workers' values and interests.

While the Party functionaries insist on democratising and re-defining the social role of the PUWP in order for the Party to be a genuine people's champion, such attitudes are very difficult to find among the old trade-union activists. On the contrary, the latter are quite vocal in endorsing the former principles of organisation and governance. This attitude appears in the above-cited assessments of Solidarity as a new mutation of the CRZZ. Moreover, the old trade-union leaders tend to believe that Solidarity must by necessity morph into a CRZZ-like structure. "Solidarity is a group of people and, let's not deceive ourselves, it'll be managed, like any other organisation, by one board or another" (Ibid., p. 15). This represents the old trade-union activists' attachment to the autocratic power system. Identification with power, comprehended as a capacity to determine what others do, and the imperative to control the members and their actions are the quintessence of the views of the old trade-union activists and demarcate their horizon of thinking about the social world and human beings in this world. For example, a long-time activist says: "The trade-unionist movement is just an addition to directives, it only serves as assistance" (B 41, p. 12), and another respondent remarks: "trade unions are a kind of humanitarian and philanthropist activity" (B 46, p. 11-12). As such, trade unions should not dabble in politics: they should control people in power positions, but the Party should do its job: "I don't approve of mixing politics and the trade-union work the way it's going on now" (B 8, p. 13). This is where the basic objection to Solidarity comes from; the respondents resent the trade union's explicit involvement in politics, which they regard as the exclusive domain of the government. Finally, the old trade-union activists define their idea of social action: "What trade unions do should be based on deliberation how people's actions should be channelled" (B 61, p. 2). Another activist and organiser of a directorial trade union characteristically speaks of his organisational effort: "It caught on, we ran it among workers, we got them round to work, etc." The respondent positively states that "I may know workers' problems better than they know them themselves" (B 3, p. 5). "I believe they need guidance, absolutely honest people need to be chosen who'll 
guide this movement and carry it on" (B 8, p. 7). "The goal was to give people a chance to do things for themselves [...], and to guide those people's activity simply for the sake of the enterprise's workforce" (B 61, p. 2), "for, after all, there must always be somebody in charge of the whole thing" (B 26, p. 13).

This pattern underlies the old union activists' entire social experience and identity. What has been happening seems an end of the world to them: they feel directly and personally threatened by everybody around - Solidarity, the PUWP, the workforce in their enterprises and the party-and-state authorities. The old union activists relatively seldom criticise their directors, even though a general critique of the "management" is not rare. Despite that, they also imply that the bureaucratic and autocratic principles are irremovable. They adopt the bureaucratic viewpoint of the state: "Of course, people's good is at stake, but you also need to consider what's good for the enterprise, after all, the workers and the enterprise are one and the same thing" (cf. B 31, p. 17). "Hence, there's no need for Solidarity in the enterprise at all, perhaps in the country" (cf. B 41, p. 13, 14). For the old trade-union activists, the state is an organiser and "a manager" of human activity.

Although many of their critical opinions dovetail with the views expressed by Solidarity and the Party functionaries, the old trade-union activists basically do not uphold the emergent ensemble of commonly endorsed social values. First of all, they uncritically cherish the former principle of governance saying that somebody must "be in charge of the whole thing." Such a person must have special competencies and be predestined for the role rather than being simply elected by the people involved. The old trade unions' activists seem unable to perceive any collective otherwise than in terms of the authorities and the masses.

Nevertheless, some of them were inclined to reconcile their own interests with the social interest in more constructive ways. This less uncompromising definition of the situation accepted a pluralist system of trade unions. On this model, Solidarity was viewed as a competitor, and productive aspects of such a situation in the enterprise were cited: "competition between the unions is a good thing [because] if one goes about some things noisily, the other tries to hush up other things" (B 62, p. 3). Collaboration with Solidarity seemed a necessity, and the old trade-union activists put aside their grudges in order to win back at least some of their membership and gain social recognition. Consequently, they often declared their good will and eagerness to be on friendly terms with the new trade union, complaining simultaneously that Solidarity did not show a lot of inclination for "friendship" (cf. B 26, p. 8). "The old trade unions stretch out their hand to the new ones, but the new ones are blind to this gesture" (B 28, p. 6); "We couldn't find a common ground with Solidarity at all" (B 8, p. 12). 
Although some respondents say that "you're really terrified of some people from 'Solidarity' [...], 'Solidarity' wants to be a ruling party and it drives the country to the edge of the precipice, provoking a foreign intervention" (B 31, pp. 4, 5, 6), they do not accuse Solidarity of being an anti-socialist force (B 8, p. 11).

Symptomatically, the old trade-union activists' way of thinking, logic of argumentation and language itself were strongly redolent of propaganda campaigns rife on television and in some newspapers at the time. Among our respondents, the old trade-unionists most frequently used the ready-made linguistic and conceptual clichés which were disseminated by the mass media. Their reflection and expression were least independent. Nevertheless, event they occasionally repudiated the propaganda language in that they did not define Solidarity as an anti-socialist force. Still, they tended to cultivate a conspiracy view of the events, even though they were not preoccupied with it, focusing on their own, rather dramatic situation.

\section{“Three Souls" of the Directors}

The definition of the situation as formulated by the directors of enterprises we studied sometimes borders on the old trade-unionists' vision, the difference being that the former are less agitated and more resolved to adapt to the new circumstances. The directors largely share the workers' assessment of the system in place and of the causes of the social crisis. Still, the directors speak, on the whole, in more precise terms and offer more detailed depictions of the chaos ripping the "planned" economy, especially when they address the flaws in the management system. Many directors also disprove the information spread by the mass media by claiming that the strikes neither disrupt discipline nor diminish production efficiency (cf. D 70, p. 17). Namely, even though the strikes result in losses, the losses are anyway negligible in comparison with the regular losses caused by power cut-offs and discontinuous supplies of raw materials (cf. Ibid., pp. 10, 12). The directors insist that wastefulness and losses are caused by ill management, wrong bureaucratic decisions and faulty central economic policies. Given all these, some directors, like the PUWP functionaries and the old trade-union activists, tend to insist that the workers' demands are identical with what the directors themselves have often urged but what has always fallen on the deaf ears of the government (cf. Ibid., p. 6, 7). Nevertheless, the directors perceive the workers' protests and the independent trade union (particularly at the time of its formation) as workers' usurpation of the prerogatives of decision-making on issues beyond their expertise. The directors emphasise that their own professional competence has been undermined although, as they admit, they have 
never been able to prove this competence, because final decisions have always been made by the "higher rung" officials and the bureaucratic reason has come to dominate over the expert reason. This insight curbs the directors' emotions, even though their feelings are often vented in the conspiracy version of history. Admittedly, the directors show how unfounded the propagandist interpretation of the genesis of the crisis is, yet they are eager to pick up rumours that the entire protest has been engineered by conspiring politicians and to patch them up together into a coherent theory. More importantly, the directors clearly look down on workers, considering themselves a separate social category - the upper class, as it is tempting to conclude. In describing the social situation, they use a specific language which objectifies workers as labour force, masses and staff, rarely defining them as people who have something important to say.

At the same time, however, the interviews with the directors register the beginnings of change in the representations and attitudes enforced by the new situation. The directors claim that Solidarity has effected a transformation in thinking which, in their opinion, is related to the political renewal (cf. Ibid., p. 18). They learn to see workers as human beings with dignity, whose opinions must be taken into account. Nevertheless, despite undeniable changes in their attitudes, the directors are hostile or distrustful towards the idea of democracy: "Democracy is a waste of time, six hours spent debating on something that takes fifteen minutes to do" (D 73, p. 9).

Still, their definition of the situation has been evolving, as they have been adapting to the new situation so as to retain their position. First, the workers' protest and the establishment of the independent trade union in the company infuriate the directors and provoke them to take action against the building of trade-union units. They define the situation as a threat to their power and to the principle of competency and expertise in economic management. A few months later, they view the situation differently. Workers become people entitled to evaluate the operations of their enterprise. Consequently, restrictions to the directorial decision-making power are accepted. The directors are still distrustful, but Solidarity must be reckoned with as a fact: "if an overwhelming majority of workers are behind it, you need to acknowledge it" (cf. D 70, pp. 11, 12). At any rate, the directors are at a loss to find arguments against the democratisation of political and economic life. Negotiations and consultations between workers and directors were taking an institutional shape even as we were collecting our data. No matter how much they valued the old trade unions and how much effort they had put into stopping Solidarity (which will be discussed below), the directors perceived the rationality of the demands put forward by the new union members. Consequently, they stopped (or at least declared to stop) meddling 
with trade-union activities and various trade unions' attempts to get on with the other ones. "Trade unions simply must come to terms with each other, and they'll do it best on their own" (Ibid., p. 13). At the turn of 1981, a working consensus was achieved at Warsaw's enterprises.

Importantly, the relationships between the workforce, in particular workers, and the directors turned into what Marxists describe as a class conflict. This is suggested by the image of workers formed by the directors, especially at the beginning of the process. The directors were opposed by a class made up by workers who had undoubtedly come to share a sense of common interest and forged bonds that organised this class. Nevertheless, it was rather "a class of employees," for only a part of the clerical segment identified fully with directors and the state as the owner and the decision-maker. The latter included primarily the company's major officers, while most specialists and other white collars rather spontaneously tended to join the workers' protest or were among the founders of the independent trade unions. Importantly, white collars felt more at risk in the belief that their disobedience was easier to penalise. Consequently, they were more predisposed to accept a compromise, even though their living conditions were inferior to workers', while their sense of social disadvantage was often more acute. The old trade-union activists, who were as a rule on enterprise payrolls, most clearly identified with the "director class." Interestingly, for all their leanings toward the directors and the old trade unionists, the enterprise-level PUWP functionaries adopted the position of mediators between the "classes."

While the PUWP secretaries often display political thinking framed by interests and values, the directors talk in more pragmatic and instrumental terms, although their rational language often articulates deep insights into national values and culture.

The directors navigate among several frameworks of reference, and some of them are aware of this vacillation. One of the directors we interviewed begins his assessment of Poland's economic and political situation and evaluation of Solidarity's activity with a telling confession: "Well, I must... two or three souls will struggle in me here" (D 15, p. 59). The directors' "first soul" is associated with the power system of the state in which they are organisers and managers of economic life. This identification framework determines the "class" relationship between the directors as a social group and the workers or, in broader terms, the employees. The directors view their membership in the "upper class" and participation in the exercise of power as grounded in their professional competency. This is where the directors' "second soul" enters the stage. As experts/engineers and experts/managers, the directors cannot possibly appreciate the rules which have so far governed the state's operations and policies. The rationality of the 
enterprise and of the economy as a whole opposes centralisation, bureaucracy and politically motivated decision-making. In this context, Solidarity must invite positive appraisals: "One thing Solidarity did to deserve the highest credit is, in my opinion, if you realise that Solidarity started fighting that evil we were faced up with in that past period. I mean this, let's call it, nutshell case or our own local case, where the abuse of power was so glaring, flagrant and blatant. The same is true on a larger scale, among many other dignitaries or non-dignitaries, economic, political decision-makers" (Ibid.). Consequently, the directors support the democratisation of the system as the only way to make production more efficient by replacing the central management with economic mechanisms and to encourage people to exert themselves for preventing the country's economic collapse.

"Reforms must certainly start from trust, there's a number of things to be done, from retracting the imposed production plans, they should be developed within enterprises and based on realities, common sense, actual possibilities. We've often faced this problem ourselves; I had a talk just a while ago, I won't go into all the economic details of it [...], but I can tell you this - this thing's imposed on us and causes misunderstandings, such misunderstandings that sometimes words just fail us. We've struggled so many years now!” (D 24, p. 8). The director envisages the following reform plan: "I'm not the only one to think so, I believe that we've had enough discussing; it's time to get down to work, learn to govern, give power to the people who can govern and not to time-servers and carpetbaggers, give power to those we've actually elected. [...] reforms to flatten the organisation structures, curb decision-making, put in an economic system where we must account and be responsible for what we're really doing, where we're given funds and means and then must show what we've done with them, and where we deal with concrete aims and not mythical categories [...], where economic categories eventually prevail and the market laws work. Let them not force us to hire ten thousand people at, say, a construction site when I know we only need five thousand [...]. That's the world I live in: I go to see the minister at the end of the year and say: 'Sir, the planned profit was eleven million zloty, and I've reached fifteen million.' The minister says: 'Director, what's this? I need you to give me at least one hundred and twenty million, I need to have at least twenty percent in excess of the plan, I need the plan done at one hundred and twenty percent.' And I must manoeuvre and cheat and somehow produce these millions from the hat to please the minister" (Ibid., pp. 9, 10).

Another director refers to the news from late August 1980 that the government does not allow establishing Free Trade Unions: "Well, there was always one explanation, right: the Party's executive role in whatever was going on. Well, especially 
over the last decade, true, all initiatives, even the smallest ones, launched in Poland, whether social, economic or cultural ones, had to boast, well, the patronage of the Party or, well, at least of the Party activists, that's how it must be understood" (D 27, p. 8). When asked "How do you understand the renewal and democratisation?" he answers: "Putting in a system of [local] self-government across the country. Without external pressures [...], especially not from people in top positions, on who is to be involved, who is to be in the leadership of self-government at all levels [...], at the lowest rung in particular [...]. Without self-government and giving all those low-rung officials [of enterprise-level workers' self-management and rural self-governments] an opportunity to act freely and democratically, I think, there won't be any effects that the nation expects" (Ibid., p. 11). "Why is it necessary? For example, in one of our departments [...] there's been a breakdown in daily production targets. Nobody spoke with these workers [...]. And a group of workers from that department spontaneously [...] agreed among themselves, and decided to work ten to twelve hours longer to catch up with the plan [...]. And I think that such initiatives will be crucial, right, what people do down there, how people think. People are starting to see that the situation's difficult in Poland, right, and it can get even more difficult, but if we believe that we work for ourselves, I mean not only for us in the enterprise, but for entire society, for the nation, such initiatives will spring up every day" (Ibid., p. 13). The respondent concludes: "We must develop a model where all initiatives, individual and collective alike, are taken advantage of rather than destroyed. That's the crucial thing, I believe, and the democratisation of life is a basic condition of such an inclination to take up initiatives across society, generally" (Ibid., pp. 14, 15).

The directors' reasoning was clear: the economy depends on economic mechanisms, including the autonomy and self-reliance of enterprises, market laws and social control of decision-making. They believed that the democratisation of the management of economy was a necessity and, at the same time, that it would promote workers' own initiatives and heightened effort. This was especially relevant with a view to combating the crisis. Reforms entailed "creating a system of autonomy for economic actors, with or without federations [...], that's a minor thing, but creating authentic autonomy, well, I guess guaranteed by a Sejm bill so that it couldn't be reverted by copier-made regulations, right? In Poland, the worst law is the copier-made law, ${ }^{62}$ which multiplies totally beyond control" (Ibid., pp. 16-17).

62 "Copier-made law" (Polish: prawo powielaczowe) was an expression popularly used in Poland to refer to unpublished, internal by-laws, legal interpretations and guidelines 
The democratisation of social life was a political condition of economic reforms. In the directors' view, this predominantly entailed the democratisation of the PUWP: "There won't be any democratisation of life in the country if there's no democratisation, but autocracy, in the ruling Party" (Ibid., p. 17). "The Party should engage in a wide-ranging dialogue with society. My view is, and it's only my private opinion, that the Party displays an enormous social sensitivity and wants to meet the aspirations of the working class mid-way, clearly showing that it's learned the lesson of 1956 and later years" (D 44, p. 11). This respondent's vision of reforms is less radical than, though in broad lines similar to, that outlined by the former one: "The point is to put in frameworks enabling some autonomous decision-making so that when you make a decision you know it'll be implemented rather than changed immediately by somebody else and questioned away" (Ibid., p. 14). The same director says: "I'd like the Party to finally brace itself up and fully represent the working class's aspirations unlike before when the Party dealt with everything, the economy in particular, less dedicated to calling people to account. I'd like the Party to finally be on the offensive. For Solidarity to stop being the foremost power in making demands and proposing solutions to problems in conformity with the expectations of the working class" (Ibid.).

The interviews cited above display a wide array of attitudes expressed by directors as experts/managers. They seek to salvage their "second souls" by embracing either the PUWP's renewal process or the Solidarity-initiated social reform process. Those who believe that they can use their competency and reconcile their professional interests with social interests voice far more coherent economic and political reform plans that those who are preoccupied with the idea of the renewal within the PUWP. The respondent cited above describes how substantially his mindset changed when the statement of a Gdansk-based director was discussed in a meeting: "This showed us finally what it was that the workers wanted, right; another thing - that the workers didn't just seek private goals and weren't only interested in what's good for them, but their attitude was socially inclusive, and then we understood, right, and I understood myself that the Solidarity trade-union movement could contribute a lot to the renewal of life, in particular to the renewal of the democratisation of life in Poland" (D 27, p. 14).

which, though of dubious legal validity, actually affected the functioning and decisions of administration bodies. (translator's note) 
Altogether, based on rational assessments of the economic system in place in Poland, the directors supported democratisation as the only effective solution to the economic crisis.

To save their "first soul," they sought to square democratisation, on which their "second soul" insisted, with the renewal of the PUWP. As a result, their programme, though clearly limited, overlapped largely with the vision of those directors who were prepared to give up their power. The latter subscribed to the far-ranging reforms triggered by Solidarity.

Yet the directors had also a "third soul," which helped them navigate these contradictions. It was their national soul: "What I see every day, those people from Solidarity" one director says, "are, after all, the most earnest Poles, the best workers, the most decent people, and I can't suspect or attribute to them any capitalist or imperialist, or anti-Polish beliefs or leanings because that'd make no sense. [...] Communism or no communism, there can be socialist loyalties, honest and unaffected, in society, for we all, and many of us, don't dream of, don't want and indeed would be hostile to the return of the capitalist system. But, on the other hand, we can't deny that we've been brought up in Western culture. That Rome, that Latin, that Church have shaped us all ideologically, with all the preferences of lifestyle, beliefs, the sense of justice, ethics, morality - all these factors have produced in us certain aspirations, ambitions, certain ideals which are entrenched in society and which are often brushed aside or forgotten, while we hasten to build the communist system. Perhaps, it's a Russification theory, that may well be, yes... Silence over some facts of our history, some differences, some antagonisms that have grown between Poles and Russians for hundreds of years, and they're not gone, they're still there [...]. We hated the Swedes for three hundred years, and today we're not entirely indifferent to things Swedish. And it will take more than twenty or fifty years for us to really start liking Russians. All the more so as their methods are, well... controversial, to us, to our... to our mentality, they're often unacceptable" (D 59, pp. 16, 17).

The directors' national soul cultivates distinctively Polish tradition and culture and understands their relevance to human aspirations and beliefs; it upholds Poland's allegiance to the fundamental values of European culture, which cannot be renounced even if embracing communist ideology. The exigency to reconcile these crucial cultural values with socialist ideology is at the same time a problem intrinsic to Poland's relations with the USSR and central to the political model. Socialism in Poland cannot be a simple replication of the Soviet model; rather, it must grow out of and conform with the principles of national culture. Just like the workers, the directors are Poles, and this compels them to redefine their relationships with the workforce. The national identification alleviates and curbs 
the "class" conflict between the directors as the ruling and the workers as the ruled. The directors come to realise that those in power must be strong, but their effectiveness is predicated on competency, while they are only legitimised if they endorse society's values and culture.

\section{Establishing Independent Trade Union Units}

The process of establishing independent trade unions, most of which quickly joined forces to form the nation-wide Independent Self-Governing Trade Union "Solidarity," was lightning-quick. By the turn of January 1981, when we stopped collecting our data, the organisational structures of the NSZZ 'Solidarity' had taken firm shape, and the tripartite division into Solidarity, the branch trade unions (the old unions) and the autonomous trade unions (to which our respondents referred as directorial) had crystallised. The process itself was uneven and, at the same time, eventful. In some of Warsaw's social circles, it proceeded rapidly and efficiently. These circles served as an "engine" that powered up the formation of the regional organisation Mazovia NSZZ "Solidarity." Two social groups seem to have been particularly instrumental in the process: one of them comprised workers of big industrial plants (with the workers of the enterprises that had gone on strike in the summer of 1980 playing the most important role) and the other included intellectuals scholars from universities, the Polish Academy of Sciences and other research institutions. As stated in the Introduction, the process of setting up independent trade unions began within these two big social circles as soon as the Gdansk and Szczecin accords had been signed. For a while, the process unfolded along two separate trajectories, even though it was propped by similar definitions of the social situation. The building of trade unions as part of Solidarity was staggeringly quick in big industrial plants, while in small enterprises and cooperatives the new union's structures were only established later. The Solidarity-founding processes were very dynamic in the health care sector, engineering services and foreign trade organisations. The latter institutions were by far the quickest among other offices to set up independent trade unions.

\section{Turning Points}

Continuous though the process generally was, it had certain turning points that accelerated the establishment of Solidarity units. Of course, the first moment came with the signing of the agreements in Gdansk and Szczecin, when a new 
consciousness evolved conterminously with the shared definition of the situation. One respondent says: "People knew things were going bad [...]. But, of course, they couldn't precisely articulate, say, their demands, what it was actually that pained them, that oppressed them. They knew that it was no good, and that they were badly oppressed, and up there [in Gdansk and Szczecin] they had it articulated for them" (S 4, p. 9). We have shown the different nuances of the social definition of the situation. Emphatically, the events produced a wide-ranging social consensus, where even people who did not support the definition of the situation (such as the job-holding old trade-unionists) did share the fundamental insights of the new consciousness, in particular regarding the causes of the crisis.

But, naturally, it takes more than just upholding a certain ensemble of beliefs (especially, if they are basic moral beliefs) for people to take joint action. People were scared (hence our respondents repeatedly state that Solidarity founders were brave people). The breakthrough moments in the union's development were those when more and more social groups mustered their courage. On such occasions, the fear of spontaneous action was gradually overcome. "We sighed with relief when the agreements were signed," recount the workers (R 67a, p. 2).

Subsequent turning points came when the NSZZ "Solidarity" was founded at the end of September and a one-hour strike was called on $3^{\text {rd }}$ October 1980 to demand the registration of the trade union and its statute. In Warsaw, the strike was also joined by enterprises where Solidarity units had not been set up yet. In one of those enterprises, the workers were so determined that the management's and the old trade union's pleading and bullying were to no avail, and the strike took place despite the threat of pay cuts (cf. B 41, p. 10).

Another breakthrough came on $12^{\text {th }}$ November 1980, when Solidarity was officially registered by the Voivodship (Province) Court in Warsaw. The trade union members were ready to go on strike in defence of their organisation. The registration definitively tore down the barrier of fear. Importantly, by that moment, the trade union's organisation structures had already been formed. Moreover, the enterprises where the trade union was established after $12^{\text {th }}$ November 1980 reluctantly admitted that the Enterprise Committees had suggested an earlier date as a rule. The registration was a turning point, not only because it marked the closure of the Solidarity-building process. It also marked a moment when a new social consensus took place. The directors' attitude to the trade union changed, which was a crucial development: "The management have regarded as us worthy partners to negotiate with ever since" (S 64, p. 17). Arguably, this process had begun earlier as in many enterprises the strike of $3^{\text {rd }}$ October 1980 marked an important breakthrough (cf. S 20, p. 28). 


\section{Models of Founding Independent Trade Union Units}

The NSZZ "Solidarity" was set up in Warsaw's enterprises based on two basic models. In one of them, the former Strike Committees transformed into the Founding Committees of Independent Trade Unions. As we know, members of these Committees decided to establish one, nation-wide Solidarity. Before this nation-wide trade union was founded, an independent, self-governing tradeunion organisation called Mazovia ${ }^{63}$ had been set up in Warsaw. The Mazovia initially assembled workers of a few big factories and some of the "intelligentsia" groupings. Elsewhere, specifically distinctly organisations were founded independently. Their merger into one trade union coincided with the founding of Solidarity. Some of the organisations set up at the time tried to expand by teaming up with enterprises from outside Warsaw. These attempts were as a rule inspired by the old unionists and supported by the managements and the Party organisations. Importantly, enterprise-level Party functionaries took care not to get directly involved in the establishment of the unionist movement. The managements were more immediately involved, because the active founders of those trade unions often held upper positions in the administration segment of enterprises. In our study, we recorded two such cases. The goal, undoubtedly, was to generate a bottom-up movement which could be controlled from the inside by the economic management. Hence, as already mentioned, such trade unions quickly came to be called directorial. Regardless of how many people were involved in developing such organisations, the process was effectively blocked by the establishment of the NSZZ "Solidarity" and the strike of $3^{\text {rd }}$ October 1980. Most employees left the directorial trade unions to join Solidarity. To our knowledge, attempts to build an organisation that extended beyond Warsaw failed even though, for example, the Niezależny Związek Zawodowy Pracowników Motoryzacji (Independent Trade Union of Automotive Industry Workers), which was set up at the FSO, assembled initially employees of major motor vehicle manufacturers from all over Poland. The Związek Zawodowy Pracowników Komunikacji Miejskiej (Trade Union of Urban Transportation Services Workers), which was founded at the MZK, followed a similar trajectory. Some of its activists remained loyal to it and cultivated their identity as members of autonomous trade unions. Yet their influence was very limited and fell short even of the impact of the old branch trade unions, which worked hard to adapt to the new circumstances.

63 Mazovia (Polish: Mazowsze) is the name of the geographical and historical region where Warsaw is situated. 
Usually loose organisational structures based on the Strike Committees could be found in the enterprises that had gone on strike in summer 1980. In some of them, the Committees had taken a distinct institutional form, which was the case, for example, at the Warsaw Steel Plant during the solidarity strike in support of the Coast strikers. Generally, the Committees had been more or less formally elected by the workers. Yet in most companies, such formal assemblies had not come into being for fear of reprisals. It was only at the end of August, when the accords were signed, that the workers whom we dubbed the discontentedand-defiant received a real boost. The Founding Committees of the Independent Self-Governing Trade Union were formed similarly to, albeit more slowly than, the earlier Strike Committees. Their (usually informal) leaders communicated with other enterprises, especially with the ones which were symbolic to Warsaw's workers. An important factor in this process was whether the workers' representatives made up a sociological group as described above.

The other trade-union formation model was found chiefly in the enterprises with no distinguishable group of the discontented-and-defiant. The signing of the agreements was a powerful motivator for people who had not been champions of collective interests before. Early in the process, they found support at what were called consultation points, i.e. mini information centres run by volunteers who offered legal advice, explained the labour law and regulations concerning organisations, distributed Solidarity statutes and, above all, dispelled doubts. Consultation points were highly instrumental in the establishment of the trade union; as was the quickly set up Mazovia organising bureau, which soon took over their functions and appointed consultants. These consultants were union members who disseminated information about the newly established organisation, made sure that new units of the union were set up in conformity with the statute and advised on practicalities involved in starting new union organisations.

This model of trade union formation involved two major stages. First, organisers came forward spontaneously. Having obtained information about establishment procedures and necessary resources, they sought prospective members. The group of enthusiasts relied on personal contacts when collecting membership declarations among the workforce. Such groups were as a rule an embryo of Founding Committees. Second, the trade union unit was officially set up and the Founding Committee were elected by those involved. Generally, this took place during workers' meetings. Sometimes the meetings were called by the already existing Founding Committees, but more often than not the Founding Committee was appointed and workers declared readiness to join Solidarity during meetings organised by the old trade unions, which tried to enlist supporters. Such initiatives of the old trade unions nearly always resulted 
in collective decisions to set up Solidarity and wound up as elections to Founding Committees. Then, the "officially" instituted Committees openly inaugurated their operations.

Of course, this model came in many varieties. For example, in one enterprise, the Founding Committee of NSZZ "Solidarity" came into being and went public with support from the factory's PUWP secretary: "Earlier, initiative groups were formed and collected membership declarations in various departments. An overwhelming majority of the workforce wanted to join Solidarity, but organisers from respective departments, who had lists of prospective members, didn't know each other. All over the factory, people talked of nothing else but setting up Solidarity, yet officially no one approached either the management or the workforce in the capacity of a union representative. The PUWP secretary invited those trade-union organisers and asked them to eventually institute an official Founding Committee and notified the company's management. The secretary gave them his office and left them alone" (cf. P 17, pp. 6, 9; S 64, pp. 11, 12). Other respondents say that, at first, Solidarity membership declarations were collected secretly, "quietly" (cf. B 41, p. 8; S 43, p. 1), then the Mazovia Bureau in Szpitalna Street was consulted (cf. S 43, p. 7), and only afterwards an informational meeting was held with a consultant from the Regional Office in attendance. What began as an informational meeting ended up as an election of the trade union's interim leadership at the enterprise (cf. Ibid., p. 3).

Ultimately, the difference between the two formation models was that wherever there had earlier been Strike Committees, they quickly transformed into Founding Committees, which worked openly based on the Gdansk and Szczecin accords. The trade union developed similarly within enterprises with an informal leader group familiar to the workforce. Such groups tended to form Founding Committees. The other model was applied if informal leaders were less popularly known or did not come forward at all. In such circumstances, the trade union initiators first sought social support and "quietly" put up lists of prospective members. Founding Committees were set up when the idea of establishing the trade union obtained public backing.

In all cases, the initiators emphasise that Solidarity did not do any canvassing. "Canvassing" sounds pejorative in this context. Consequently, the common opinion is that there was no canvassing whatsoever and people joined the union entirely of their own accord. Workers themselves spontaneously approached Founding Committees, while their common will and repeatedly expressed expectations fashioned certain people into trade-union organisers (cf. S 22, p. 3; S 25, p. 3; S 76, p. 8; S 29, p. 7; S 67a, p. 3, 4; S 19a, p. 7). 


\section{The Organisers}

It is interesting to find out what people were the most active founders of Solidarity. Our study offers quite untypical answers. We directly asked our respondents about it. Their accounts help verify the empirically generalised statements and see how social stereotypes interact with the new consciousness of social actors.

That the union was set up by young zealots is the most common stereotype our respondents voice (cf. e.g. S 22, p. 2; S 29, p. 12). Solidarity appears to be the work of youth. Older people were distrustful (cf. S 29, p. 3; S 74, p. 9), but were ready to offer advice, leaving action as such to the young (cf. S 25, p. 3). This is restated in interviews with the activists of both Solidarity and the old trade unions. At the same time, when comparing interviews from respective enterprises, we found out that in all cases people who were most committed to establishing trade-union organisations represented very different age groups. The stereotype on which the actors rely in describing their own actions is true insofar that, across the enterprises, the oldest employee group on the verge of retirement (i.e. 55 years of age and older) indeed remained uninvolved as a rule. They were also not very eager to offer "good advice"; very clearly, they did not want to have anything to do with organisational work, irrespective of their appraisal of this work. It is not true that the youngest employees were particularly active as organisers. The young of the stereotype are in fact older than 25 years of age. The picture of the events sketched by the interviews suggests that the core age group among Solidarity organisers were people who are popularly described as "adults" or "in their prime." Psychologically speaking, this is a fairly banal finding as the time between adolescence and old age is as a rule a period of expansion. Consequently, not so much the young as rather people between 25 and 50 years of age were the most active group in the formation of Solidarity.

Still, in the foregoing we proposed a generational hypothesis which said that, in Warsaw at least, similar social experiences of two generations were particularly instrumental in the development of social action. These were the intelligentsia generation of March 1968 and the worker generation of June 1976. The two observations - that a wide range of age groups were actively involved in the events and that the two generations were particularly important - can actually be reconciled. Admittedly, the consciousness of the generations which, on entering social life, had directly experienced the March and June events had a strongly formative impact on the new social consciousness in Warsaw. This, however, does not mean that these two generations were the sole important actors of the Solidarity formation movement. Simply, their way of thinking and lifestyle 
seminally informed the behaviours which were picked up by other generations which were as eager to act on behalf of society.

Another thing our respondents persistently repeat is that the most active union organisers were production workers (cf. S 29, p. 4) and other low-ranked employees (S 22, p. 3; S 25, p. 4) whereas engineers, senior workers and whitecollars were more timid (S 21, p. 27). The respondents often contrast the most active group of ordinary production workers with the clerical staff and the technical intelligentsia without executive positions, who were reportedly less involved in setting up the trade union. This stereotype finds more corroboration in empirical reality than the age stereotype. However, no single enterprise in our data had Solidarity organised without active engagement of one or more white collars and technicians. Especially engineers and technicians directly responsible for technological processes, rather than for enterprise management (employed in engineering and construction offices, laboratories, etc.), were extraordinarily committed to organisational work. Still, the stereotype seems to represent quite accurately the general attitude of respective workforce groups to the idea of establishing the trade union. Workers wholeheartedly supported the idea, while the same cannot be said about white-collars. The very active individuals hailing from the latter group were rather "untypical" of it. Importantly, however, the "untypical" office employees were to be found in each and every enterprise. This can be explained by resorting to the generational hypothesis. The "untypical" white collars were usually members of the March'68 or June'76 generations.

Finally, our respondents state that toolroom crews (or analogical worker groups, e.g. repairers) were most actively involved in the formation of independent trade unions (cf. S 76, p. 5; S 38, p. 11, 12; S 66, p. 4; S 20, p. 8). In this case, the common opinion accurately reflects the actual events. The toolroom workers, or their equivalents, were the backbone of social action.

\section{Impeding the Formation of Independent Trade Union Units}

Another important question to answer is who was hostile to or opposed the formation of trade unions. Our respondents point to: middle-rank management (S 37, p. 14); foremen, middle-rung control personnel (S 38, p. 20; S 66, p. 10); those "glued to their jobs" (S 7, p. 11); people in upper positions who had good income and enjoyed privileges (cf. S 37, p. 10); people losing their privileges (S 29, p. 21; S 64, p. 6; S 36, p. 18); people in high positions (S 30, p. 6; S 21, p. 17; S 38, p. 21; S 66, p. 10); office employees (S 64, pp. 7, 26); and directors as "silent enemies" (S 76, p. 4; S 29, p. 8; S 30, pp. 7, 8). Also counted among 
the opponents of new trade unions are $\mathrm{ZSMP}^{64}$ activists and the management's henchmen (S 29, p. 13; S 30, p. 5). Characteristically, neither membership in the PUWP nor even being an enterprise-level Party functionary is straightforwardly associated with any specifically defined attitude to Solidarity. According to the widespread opinion, some PUWP members were "for" while some others were "against" Solidarity (cf. S 76, p. 20; S 43, p. 7). The accounts of social actions and the attitudes reported by PUWP members indicate that Party membership did not directly translate into a person's positioning in the social process and was not a differential factor either in strike participation in the summer of 1980 (cf. S 20, p. 9; S 66, p. 13) or in trade-union organising (cf. S 22, p. 17; S 29, p. 13; S 30, p. 5,6). Divisions and differences in attitudes appeared when Party membership connoted certain privileges.

Activists who were on enterprise payrolls and had full-time jobs in the old organisations firmly opposed the formation of the new trade unions. However, some of them abandoned their former organisations and functions to contribute to the organisation of new unionist institutions. This process was supported by so-called trustees, i.e. the lowest-level old trade-union functionaries who were, as a rule, indeed elected by their colleagues and advocated for them (cf. e.g. S 20, p. 12).

Early in the development of the unionist movement, the establishment of Solidarity was also opposed by enterprise directors, as mentioned above in the discussion of how their attitudes evolved.

The opponents of setting up independent trade unions were usually an organised group. They were members of one or another institution, such as the old trade unions or company managements. The measures they used against the Solidarity movement can be roughly divided into practical and symbolic. The former included blocking social action and/or harassing individuals involved in it. The latter comprised an array of means aimed at affecting people's consciousness and attitudes so as to discourage them from establishing a new trade-union unit.

\section{Practical Measures}

The key practical measures involved preventing the development of spontaneous social action and molesting those who engaged in it. Such measures were already applied during the strikes and continued in September and October 1980. The

64 ZSMP is the acronym for the Związek Socjalistycznej Młodzieży Polskiej - the Polish Socialist Youth Union. (translator's note) 
directors' responses were symptomatic: they became furious, publicly yelled at workers and their representatives and hurled dismissal threats (cf. S 20, pp. 13, 14, 28; S 21, p. 23). They issued orders which prohibited, for example, gatherings of more than three people on factory grounds (cf. S 38, p. 8). A passageway between two state institutions was sealed off when the Solidarity Founding Committee was formed in one of them: "The passageway had to be closed to prevent that from spreading" (cf. S 25, p. 2; S 22, p. 10). Telephone service within enterprises was disrupted, and/or phones used by the union founders were wiretapped. Company mimeographs were usually claimed to be broken or to have no "processing capacity" to print union-related information (cf. S 76, p. 21; S 29, p. 8; S 30 , p. 5; S 20, p. 18; S 66, pp. 5, 12). Employees who hand-copied such information were threatened with job loss (see S 20, p. 18). Rooms were hardly ever available for meetings during which trade unions were expected to be formed or their leaders were to be elected (S 38, p. 18; S 66, pp. 3, 9). Foremen were instructed to tear down bulletin boards of the newly set-up union or remove notices and leaflets from them (S 38, p. 18; S 20, pp. 20, 29; S 21, p. 26). Lists with the names of prospective new trade union members were snatched (cf. $S$ 38, p. 18; S 66, p. 6). If the Founding Committees were formed anyway (which was basically always the case), directors claimed the right to censor and control communications of Solidarity broadcast over the enterprise's p.a. (cf. S 22, p. 11; S 76, p. 2; S 66, p. 32). Attempts were made to intimidate individual activists by summoning them to a "talk" with the management and the PUPW secretary (S 22, p. 1, 2). Reprisals against activists were launched, including worse jobs, reduced pay and initiation of dismissal procedures. Sometimes people were sent warrants for questioning by the People's Militia (cf. S 29, p. 9; S 3, p. 15; S 37, p. 7; S 19a, p. 9; S 21, p. 13; S 29, p. 21; S 66, p. 6).

When such measures failed, in some enterprises bribes were offered to tradeunionists, such as better-paid jobs, car-purchase coupons and other coveted goods (cf. S 76, p. 19; S 36, p. 14; S 74, p. 6; S 20, p. 30).

\section{Symbolic Measures}

Symbolic measures were widely used by the old trade unions. Their activists tried to pressure people by telling them they would lose their deposits in their enterprise's savings and loan scheme along with all social benefits, from bonuses to holiday subsidies and paid sanatorium vouchers (cf. S 76, pp. 3, 6; S 29, pp. 3, 11; S 67a,p p. 6, 7; S 20, pp. 15, 20; S 21, pp. 7, 19). Such threats were also spread by PUWP functionaries (S 35, pp. 1, 3; S 36, pp. 12, 14; S 74, p. 10; S 43, pp. 3, 4) and ZSMP activists (cf. S 38, pp. 15, 20; S 66, p. 11). The old unionists also 
tried to undermine people's confidence in the legitimacy of the new trade union and legal regulations concerning social and union perks. They picked up and warped Solidarity's slogans (cf. S 76, p. 21; S 20, p. 13; S 66, p. 3) and manipulated information. At the same time, in many enterprises a negative, "split" image of Solidarity was disseminated, which pictured the independent trade union as torn by clashes between extremists and moderate members (cf. S 22, p. 16; S 38, p. 19; S 66, p. 6). Rumours were spread, Solidarity activists were slandered, and fears were fuelled by circulating reportedly confirmed information about homesearches and arrests among members of the newly founded organisation (cf. S 22, p. 12; S 76, pp. 2, 11; S 29, pp. 7, 18; S 30, p. 26; S 74, pp. 7, 8).

Generally, the symbolic counterstrike against the founding movement of Solidarity was based on three major measures. First, insecurity and anxieties about subsistence were fuelled. Second, attempts were made to re-ignite the fear of politics long entrenched in society. As social activity within the trade union was also political activity, its legality was questioned by appealing to the ideas of law and lawfulness. Third, a negative picture was promulgated of Solidarity activists of various levels, i.e. within enterprises, the regional organisations and the National Commission. Two methods were especially often applied. One of them involved fabricating pejorative images of individuals and insinuating their moral inferiority. The other focused on spreading the idea that Solidarity activists were clearly divided into conflicted groups which fought for power. This aimed to make people suspect that the trade union's representatives used the "masses" to their own ends.

\section{Solidarity's Organisational Dilemmas}

It seems, however, that the symbolic influence of institutions which opposed the social movement was little effective. People were rather preoccupied with social work and ongoing debates on the problems accompanying the founding of a new institution. Three major groups of such problems were encountered: 1) a lack of models; 2) a lack of communication channels and the weakness of social bonds; and 3) the pressure of social expectations on the union as a whole and on its individual units.

\section{Lacking Models}

Most of our respondents who sat on Solidarity Enterprise Committees repeatedly complained: "We didn't know how to go about it." The six months that it took to establish the organisation and make it operate on a daily basis meant learning about the rules of institutional work. The abstract ideals had to be 
"translated" into fixed procedures and models of collective and individual action for the sprawling organisational machine. Hence, people needed first and foremost historical and sociological knowledge. Legal expertise proved absolutely indispensable for two reasons: first, in order to demand the observance of laws and to know what demands and decisions were legal, especially regarding labour and social answerability; second, in order to call for amendments or changes to the legislation in force. The primacy of the rule of law had been one of the most pronounced elements of the new organisational order since its very onset, as it was directly associated with the ethos and moral values that motivated people.

The study of the past provided some relevant knowledge since, after all, the history of Poland and other countries supplied information about the ways of organising and deciding on the social order. As such, it could offer precious guidelines about constructive legal and institutional solutions. At the same time, history and sociology were sources of models to which to resort in particular circumstances. Everybody knew that Enterprise Committees should be democratically elected, yet very few knew how exactly to go about it so as to make the process efficient and indeed enact the democratic ideals.

But acquiring literal knowledge was a means to an end rather than an end in itself. The learning that the Solidarity activists address in the interviews entailed primarily the collaboration of the social movement actors in developing clear rules on which to base the organisation's routine operations.

Inevitably, different principles clashed in the process. Some value conflicts were caused by the circumstances which the union faced. The fundamental dilemma involved striking a balance between fully democratic decision-making and the necessity for Solidarity to be quick and united when confronting the party-and-state authorities, which required a degree of centralisation. The struggles in which the union was involved promoted some decision-making at odds with the democratic ideal of having all the parties concerned (i.e. all members of the organisation's relevant unit) contribute to important decisions. Yet, any considerable fragmentation of both demands and goals threatened to weaken the organisation as a whole (cf. S 4, pp. 32, 33; S 3, pp. 9, 10). There was also another dilemma. Undoubtedly, Solidarity was set up as a trade union, but at the same time most activists and members insisted that the trade union must also guarantee reforms and control the state authorities. "Solidarity safeguards respect for human dignity" (S 37, p. 19). "Solidarity is a social guarantor of the rule of law" (cf. S 4, p. 36), "a guarantor of obligations the state institutions took up" (cf. S 6, p. 1), "a guardian of worker rights" (cf. S 37, p. 19); briefly, Solidarity warrants 
the democratisation of social life (cf. S 76, p. 6; S 43, pp. 12, 17; S 64, p. 28). To perform this general social and reformatory role effectively, Solidarity needed uniformity and efficiency and, consequently, had to limit plurality and lengthy deliberation. However, it was exactly in making these principles a social reality that the union's fundamental value resided. Internal democracy was thus an imperative and had to be reconciled with the "external" actions the union undertook.

Yet another dilemma involved a clash between equal and common participation in decision-making, on the one hand, and the rationality of decisions on the other. Sound decisions come from the expertise of decision-makers, while common participation is largely incompatible with expertise and rationality. "Democracy must above all be based," one respondent says, "on taking into account opinions of many people, first of all those who have most to say on the matters at hand, who know about them, because such people can kind of judge on such issues" (S 3, p. 15). How can this contradiction be solved?

It is also challenging to square the insistence on the union to have varied mass membership (as only such a union can effectively protect the interests of working people) with the necessity to lobby for narrower interests of individual occupational groups (cf. S 3, pp. 9, 10).

Models to follow were also lacking in far more "mundane" and "minor" issues, e.g. drafting election procedures, establishing strike decision protocols (cf. S 20, pp. 21, 22), developing collaboration rules with the management and other trade unions (cf. S 64, pp. 17, 22, 23), etc. These problems surfaced because, as a respondent says, "none of us was a bureaucrat" (S 6, p. 19), and nobody wanted to use procedures of the state bureaucracy as a model.

\section{Lacking Communication}

Our account of the formation of the NSZZ "Solidarity" repeatedly evokes social bonding. The building of an independent trade union powerfully modified social relations. It altered the sense of social community, gave rise to new social circles, produced new criteria of experiencing community with others and forged new rules which made it worthwhile for people to bond in bigger groups. At the same time, social bonding was thwarted as there were no firmly established communication channels between groups, strata and territorial communities, while interactions among people were limited and weak. This considerably impeded activities of the emerging trade union as several examples in the foregoing indicate. In most cases, enterprise collectives only developed a sense of community and a complex network of personal ties while involved in organisational unionist 
work. This corroborates a recent thesis eloquently argued by Stefan Nowak, ${ }^{65}$ who claims that in Polish society there is a substantial "gap" between "midrange" group bonds (such as bonds among family and close friends) and the sense of national community. In the process of building an independent trade union, people had to overcome several barriers caused by the fact that they did not know each other and that structurally separate societal segments had hardly any contacts with one another. To bridge such gaps, the basic network of human ties and contacts, i.e. bonds of family and friendship, was employed. Contacts between representatives of enterprise communities and their trade unions tended to be greatly facilitated if former schoolmates, friends from university or neighbours worked in the respective enterprises. Informal contacts were the basis for establishing relationships between communities and for constructing a network of social communication. Initially, such a network was the primary channel for disseminating union-related information.

This had its undeniable advantages, as it enhanced the sense of security, mutual loyalties and people's dedication and commitment. However, there were downsides as well. Obtaining and transferring union-related information proved highly time-consuming. And when people who carried such information fell ill, contacts were interrupted. The Solidarity activists whom we interviewed repeated time and again that a stable and efficient information network was essential to the trade union especially when activists had increasingly less time to go about that problem themselves. As a rule, the first thing Solidarity did as soon as founded at an enterprise was put up a poster or a bulletin board where new information was posted every day. The demand for current, updated information about the union's activities was huge.

\section{The Pressure of Social Expectations}

The new trade-union organisations proliferated and expanded at a truly staggering pace. As a result, Solidarity at Warsaw-based enterprises had already embarked on routine organisational activities by the time we conducted our study, i.e. by the turn of 1980. Solidarity activists keenly felt the weight of work on their shoulders.

65 See Stefan Nowak, “System wartości społeczeństwa polskiego," Studia Socjologiczne 4, 1979; and Stefan Nowak, "Przekonania i odczucia współczesnych," in Polaków portret własny, ed. Marek Rostworowski (Kraków: Wydawnictwo Literackie, 1979). Cf. also Ireneusz Krzemiński, "Latentne wzory kultury a dynamika postaw społeczeństwa polskiego," in Dziedzictwo Stefana Nowaka, ed. Antoni Sułek (Warszawa: Polskie Towarzystwo Socjologiczne, 1992). 
In the interviews, many of them talked about the mounting fatigue and the huge workload. Many of them also addressed a symptomatic phenomenon which we referred to as the pressure of social expectations. Members of the new organisation, who were still largely busy building its structures, continued to set new goals for the union and to make new claims on the trade union's elected representatives.

At most Warsaw-based enterprises, the hot summer of 1980 saw workers draw up long lists of demands. Some items on the lists concerned issues specific to respective enterprises and could be dealt with locally, while other ones required broader operations. At the very start, Solidarity as a union was expected to make sure that the demands were met. Some of the demands pertained to the organisational and operational details of the trade union, yet other ones were addressed to the management, and Solidarity was supposed to monitor their fulfilment. Besides, the still evolving trade union had to focus on welfare issues at hand, taking over some functions of the old trade unions - some only because Solidarity members always defined their union's role in slightly different terms than the old Enterprise Councils had done before. This position was pithily and pictorially expressed in saying that the trade union and its enterprise-based units had other things to see to than apples, carrots and grab-bags. Still, the savings and loan plans, allowance-granting procedures and holiday and sanatorium schemes were considered important issues.

In most cases, Solidarity Enterprise Committees set up special units to deal with and realise the incoming requests and demands. Solidarity was also actively involved in the work of analogous management-appointed bodies, which usually included representatives of all organisations from a given enterprise.

This notwithstanding, new requests and demands continued to pour in. They concerned enterprise-specific issues, the trade union's activities within the enterprise and its nationwide operations. Recognising them as valid, the new trade union's activists realised, however, that no matter how hard the union worked, it stood no chance of meeting all those expectations. Apparently, our study captured the moment of society's great elation at having their own, independent trade union; people tended to expect it to deal with all their solicitations concerning living conditions, social issues, political activity and cultural participation. Solidarity, so to speak, symbolically embodied the dreams of a better life, a life of dignity, and seemed to have come into being to open up a space of self-fulfilment for people. Active involvement in Solidarity was thought of as a mode of self-realisation. Solidarity units found themselves under the constant pressure of social expectations concerning nearly all spheres of life. Unsurprisingly, it started to become obvious that the trade union must choose one field in which it could reasonably achieve its goals and set the limits beyond which it would not venture, lest it found itself completely stranded. 



\section{Part Two What Was Solidarity? Interpretations of the Solidarity Trade-Unionist Movement: Introduction to Part Two}

The first part of this book contains findings of a sociological study which was carried out in compliance with scholarly, albeit not entirely standard, principles. It sketches an empirical picture of Solidarity. The second part, in turn, is of a slightly different nature, even though it also includes sociological essays. These essays, however, represent theoretical interpretations of the very phenomenon of the Solidarity trade-unionist movement and its meanings. While scholarly, these essays comprehend scholarship in rather broad terms.

In my interpretations of Solidarity as a social movement, I address not only socio-political reality but also spiritual and cultural reality, to put it somewhat enigmatically and perhaps pompously. Nevertheless, it is my deep belief that people's spiritual reality has its sociological dimension as well. This is what I focus on, particularly in the chapter devoted to "The Rooted World."

The disputes about the significance and nature of the Solidarity movement, about its ideological substance and thus about its spiritual relevance are by no means a thing of the past. In the mid-1990s, polemics and discussions were rife in international (especially US) political science, political anthropology and the philosophy of politics, concerning such issues as whether Solidarity thinking was socialist or rather liberal, whether the cradle of Solidarity was the working class or rather the intelligentsia, whether the demands Solidarity made were entitled and utopian or rather pragmatic and democratic, whether the Solidarity movement was underpinned by nationalist attitudes or rather by the national, but also democratic and universalist mindset, etc.

In Poland, the dispute about how to interpret the Solidarity social movement has, for the most part, been relegated to a kind of an aside and has unfolded indirectly in polemics and political struggles. Essentially, the attitudes and the 
projects of arranging social life attributed to Solidarity have been changing. This is what other essays in this part are devoted to.

Very little has survived today of the original ideals cherished by the independent, self-governing trade union, even though 1997 was marked by the electoral victory of a coalition formed on the basis of Solidarity and mobilised against the post-communist party. This is what makes me all the more determined to salvage from oblivion the image of Solidarity as a project of a civil society comprehended as a community of equal, free and diverse citizens. Although this extraordinary experiment, which had involved millions of Poles, turned out to be just another short-lived dream in social history, it certainly deserves to be registered and remembered.

Solidarity was a civil movement, and denying this today is caused by projecting the later ideological changes back onto the past of the trade-unionist movement. 


\section{The Rooted World}

While explaining the social experience of Poles over the last dozen years can be a challenge to anybody who seeks to understand the world, it is a very special challenge, indeed, to sociologists and the sociological study of social life. So far, the accounts and assessments of the social developments which took place in Poland between 1980 and 1986, therein in the "mythical" year 1984, have been dominated by narrowly political or "moralist" standpoints. Understandable though such an approach is, we must not stop at it. Obviously, the years 1980-1981 are a crucial period. No matter what happened later and regardless of all failures, the efforts Poles then made to build a civil society have been and still are vital to the future. For this simple reason, it is urgent - ever more urgent as years go by - to use the lived social experience of those years in a more durable and more systematic reflection than exclusively political insights. The experience was so unique that it powerfully expands our knowledge of social life as such. It calls for revising the conceptual apparatus employed in scholarly investigations of the human world and for developing effective instruments to preserve this exceptional social experience.

This obviously requires a concerted action. My argument in the following is only a first, tentative step in such an exploration.

I will focus on psychological and sociological peculiarities of the mechanisms of social life which have been at work in Polish society over the recent years. How very peculiar they have been is revealed when they are studied by means of modern sociology's conceptual grid, which seems, after all, tolerably comprehensive and flexible. Even though a very general interpretation of the developments in Poland can be usefully furthered by a variety of sociological concepts and approaches, it turns out that many essential aspects of social life and, by the same token, of the human personality find themselves outside the horizon of the conventional social-scientific scrutiny.

I will address this with caution: my point is only that sociology's scholarly paraphernalia presuppose (unwittingly as a rule) a certain image of society and the human being. This image is informed by some or other philosophical tenets which preclude studying certain aspects of the world without which, however, we cannot grasp the totality of social experience. It is not my aim to dispute the ideological and/or philosophical foundations of sociological thought. I just notice that objective scholarly sociology is based on very particular metaphysical 
premises and that in order to develop sociology theoretically, we need to avail ourselves of philosophy again.

The call to found theoretical sociology on a philosophy that delves into the mysteries of existence, rather than on the positivist philosophy of science, is by no means a novelty (in Poland it has been vocally advocated by Edmund Mokrzycki $\left.{ }^{66}\right)$. More palpable than any scholarly experiment, social experience as such turns this call into an imperative.

Still, I will not explore this issue. Instead, my argument in this chapter will be guided by the following questions: What singularities of social life come to light when we confront sociology with social experience? What is it that is patently observable in Poland but is notoriously ignored in the scholarly study of society? How can the universal meaning of the particular "Polish" experience be conveyed in the language of social scholarship and popular science? My answer will be tentative, fragmentary and, by necessity, not rigidly scholarly. I will offer a sketch which can serve as a starting point for a more structured, rigorous and thoroughly documented study.

\section{Civil Society: How the Idea Developed}

The vast social movement of Solidarity has been interpreted within various frameworks as a trade-union movement and a social reformist movement. The existing accounts usually suggest that the distinctive feature of the movement was that it amalgamated several different elements into a cohesive whole. The aggregation of these components into a developing social action and an integrated structure of aspirations determined the movement's dynamics and success. This is the gist of conclusions proposed by Alain Touraine, who studied Solidarity as a social movement. ${ }^{67}$ On his model, Solidarity pursued three kinds of goals: tradeunion goals, societal goals and national goals. The democratisation of social life

66 Cf. especially Edmund Mokrzycki, Filozofia nauki a socjologia: Od doktryny metodologicznej do praktyki badawczej (Warszawa: PWN, 1980), in particular the Chapter entitled "Filozofia nauki w perspektywie teorii kultury."

67 Cf. Alain Touraine, Michel Wieviorka, François Dubet and Jan Strzelecki, Solidarité. Analyse d'un mouvement sociale. Pologne 1980-1981 (Paris: Fayard, 1982); for the English edition, see Solidarity: The Analysis of a Social Movement, trans. David Denby (New York: Cambridge University Press, 1983); Cf. also Paweł Kuczyński et al., $W$ poszukiwaniu ruchu społecznego. Wokót socjologii Alaina Touraine’a (Warszawa: Oficyna Naukowa, 1994). 
was sought by and through a trade union that stood up for workers' interests within enterprises vis-à-vis the state as an employer.

Social liberation and political democratisation were a springboard for actions geared to preserving national identity and attaining national sovereignty. According to Touraine, such intertwining of the three threads of action determined the trade union's success and the social movement's goal achievement. The coherent and unified set of goals of common social action also structured people's individual motivations. While dedicated mainly to trade-union activism in defence of basic sustenance and living conditions, people were compelled to think of the principles of social life and institutional rules within and through which they could best express and stand up for their interests. The right to advocate for one's interests meant that collective life had to be reformed so as to make societal institutions directly and controllably presuppose and guarantee respecting individual rights in their daily practices. Without this, people could not freely express their genuine interests, and without a free, unintimidated expression of interests, it was impossible to defend those interests and, simultaneously, advance the common good.

The "new rules" (i.e. observance of the law) immediately ushered in the question of political and national sovereignty. Namely, social liberation entailed the state-and-party authorities embracing the new principles, which only made the dependence of Poland's government on the Soviet Union all too obvious. Consequently, all the components of this triadic structure were necessarily interrelated, while logical and empirical necessities overlapped, at least in the most general definition of the situation. Mediations among and interactions of these three layers - an interplay of desires and possibilities, hopes and risks, aspirations and limits - released an extraordinary collective and individual mobility in Poland in 1980-1981, which continued later as well, albeit somewhat diminished.

Insightful as this interpretive framework is, it does not answer some questions and invites other perspectives to fill in its gaps. Admittedly, Touraine's model aptly presents the basic structure of collective and individual motivations within the Solidarity movement and offers a comprehensive analysis of the movement's actions and activities, yet it leaves us at a loss as to where such a motivational and action structure came from. Although Touraine explains why and how elements which are as a rule separate were combined and why such a "totality" of goals made sense, he cannot show the origins of this complex structure.

I believe that the notion of "civil society" can effectively help us depict the impulse that opened up a new perspective of self-experience and worldexperience, of re-thinking the self and the world and of viable action. 
The idea of civil society is by no means a simple one, and the model of social life it projects is multi-layered, complex and hardly straightforward in an existential sense. It cannot be expected that such an intricate idea will be an "impulse." However, the core of civil society can be rendered very plainly and is rooted in elementary human experience. The fundamental observation that underlies civil society can indeed serve as a creative impulse. This observation, which can appeal to all of us and which every human being can recognise as his/her "own," was powerfully expressed by Simone Weil:

Difference between slave and citizen (according to Montesquieu, Rousseau...): the slave is subdued to his master, and the citizen to the laws. No doubt the master may be very kind and the laws may be very harsh; it makes no difference. The whole point is the difference between caprice and law. [...] Why is it slavery to be subordinated to caprice? The ultimate reason is in the relation between the soul and time. Whoever is subdued to the arbitrary is suspended on the thread of time; he is obliged to wait (the most humiliating state!) for what the next moment will bring him. He has no control of his passing moments; for him, the present is not a lever by which he can act upon the future. ${ }^{68}$

I believe that the acutely humiliating experience of having "no control of passing moments" and being "obliged to wait what the next moment [would] bring" with this entirely depending on the party-and-state authorities - triggered the formation of the social reformist movement and the trade union.

It is left to sociology to re-trace and explain the process in which people, on a mass-scale, came to view life dictated by the previous rules as humiliating and decided to assert themselves actively as citizens. The essence of the "hot summer" of 1980 and the creative, constructive appeal of the Baltic Coast strike, with its twenty-one demands, lay in that it was not only, and even not so much, a revolt but rather a productive action underpinned by a positive social agenda. We must thus scrutinise the process in which people came to believe that they were citizens and, as such, they must behave like "citizens," i.e. actively assume responsibility for their passing moments and, without waiting any longer, take care of themselves, their families and their country as the common good. This realisation and the impulse it produced initiated joint action and set its goals.

The process had been brewing since 1976. I described it elsewhere, based on the findings of a study on establishing independent trade unions at various

68 Simone Weil, First and Last Notebooks: Supernatural Knowledge, trans. Richard Rees (Eugene: Wipf\&Stock, 2015), pp. 19-20. 
enterprises, which was carried out in the Warsaw area at the turn of $1980 .{ }^{69}$ Rather than rehearsing my entire argument here, I will only list several factors that impacted the process: first, the "conditional" recognition of Edward Gierek's leadership which hinged on the promised modernisation programme; second, the collapse of social expectations connected to the programme and the violation of working people's - in particular workers' - self-dignity in 1976; third, the rise of the democratic opposition that championed a moral agenda of the renewal of social life, focused on human rights in real socialism, and fostering bonds between the intelligentsia and common people; four, the influence of Catholicism and the Church, which promoted human subjectivity in the wake of the Vatican Council reforms; fifth, the election of Cardinal Karol Wojtyła as pope and, in particular, John Paul II's visit to Poland in 1979, with his teaching about the human person's "natural rights" as rooted in the transcendental order of values; six, the aggravating economic crisis, whose political causes were becoming ever more obvious to the broad public as the former modes of (at least partial) legitimisation of the power system were losing their viability. ${ }^{70}$

\section{The Definition of the Social Situation and the Need for Roots}

In the process, the definition of the social situation was formulated and capped. People came to understand with all clarity that the rules of social life and, above all, the modes of the exercise of power not only undercut people's dignity and self-worth but also did not warrant fulfilment of basic needs and interests. Social thinking and action were underpinned by the belief that the principles of collective life and institutions' approach to people, to society, must change as they determined the living standards and economic outcomes.

First and foremost, the position that the state took vis-à-vis society had to change. Even though ineloquently articulated and hazily formulated, the idea that the time had come to change the rules of governance and the exercise of power, which decisively affected both the economy and people's interactions, lay

69 Cf. Ireneusz Krzemiński et al., Polacy - jesień '80. Proces powstawania niezależnych organizacji związkowych (Warszawa: Instytut Socjologii UW, 1983; and a 2005 re-edition).

70 See "The Formation of the Social Movement" (p....) in "The Rise of the Independent Self-Governing Trade Union 'Solidarity"” (p....). in this volume. The process is also analysed by Grzegorz Bakuniak and Krzysztof Nowak in "Procesy kształtowania się świadomości zbiorowej w latach 1976-1980," in Społeczeństwo polskie czasu kryzysu, ed. Stefan Nowak (Warszawa: Instytut Socjologii UW, 1984). 
at the foundation of the evolving movement. The goal of reforming social life was conspicuous, especially at the early stage of social action. Social action did not aim to seize power or wrest it away from the governing PUWP, but to force the Party, if it wanted to retain its position, to change the rules of the game and accept equal laws for itself and society. The feeling of enslavement and violation of human dignity was induced by a system of privileges enjoyed by the partyand-state functionaries. The system of privileges perpetuated the superiority of "people of the regime" and gave them the prerogative to decide about their lives and the life of the collective. Law had become an instrument for ruling and managing social life, and the system of state institutions hampered free and spontaneous social action. The social system produced by the Gierek cabinet uprooted people by subordinating them. "To be rooted," says Simone Weil,

is perhaps the most important and least recognized need of the human soul. It is one of the hardest to define. A human being has roots by virtue of his real, active and natural participation in the life of a community which preserves in living shape certain particular treasures of the past and certain particular expectations for the future. This participation is a natural one, in the sense that it is automatically brought about by place, conditions of birth, profession and social surroundings. ${ }^{71}$

The feeling that the socio-political system worked to uproot people, to wrench them out of the ground, was the substance of the definition of the social situation which was commonly formulated during the "hot summer" of 1980. Part of this definition was that, though being at home, people did not feel at home and that, though being themselves, they did not feel themselves.

Civil society best responds to the need to feel at home and to be genuinely oneself. This is so because civil society is based on the idea that every member of a community, whoever s/he is and whatever his/her role in the community, has a right to decide about his/her life and speak out on all matters that concern him/her. His/her voice can be foolish and may be dismissed, but his/her fellow citizens cannot deny him/her the right to speak out.

His/her voice can support wrong decisions, and s/he can be held accountable for that, yet nobody can strip him/her of the right to express his/her views and decide for him/her by assuming that $\mathrm{s} / \mathrm{he}$ is less intelligent, has ulterior motives or does not deserve to decide on anything. In this sense, civil society fosters people's roots in the world, for it does not take any special effort to be a citizen - reaching the age of majority is enough. Being a community's legitimate

71 Simone Weil, The Need for Roots: Prelude to a Declaration of Duties toward Mankind, trans. Arthur Wills (London and New York: Routledge, 2003), p. 43. 
member and being a citizen are both one and the same thing. For this reason, as soon as collective social action began, "democracy" became a catchphrase on everybody's lips.

Of course, this relationship can be construed as having the opposite vector, and the social process triggered by the work of establishing independent trade union units can be said to have revealed and espoused the core idea of democracy.

The process showcased the fundamental, cultural - spiritual, perhaps meaning of democracy as more than just a system of governance, a type of political practice or a technique of decision-making. Essentially, democracy demarcates and is demarcated by the human condition, affects the individual's self-image and frames human bonds.

\section{The Cultural and Spiritual Relevance of Democracy}

As a form of civil society, democracy safeguards the fundamental value which determines the meaning of human life, i.e. the sense of dignity, the feeling that I am free to be myself and have the right to retain that spontaneous sense of self. I cannot enjoy either the sense of self or the sense of dignity and, consequently, I cannot feel "rooted" if I have been denied the right to be myself, if I have not experienced having my own place in the community and having personal rights, regardless of my vices and virtues, my achievements and failures. I may put these rights to a better or worse use. I may fail to take advantage of them or to recognise them altogether. But the rights I have as a member of a community are inalienable and, basically, make me equal with all other people as persons. Democracy is a state in which all people - not only I, but also all others - can be citizens, and in being citizens, they can be themselves and have their own place in the world, in the social world, among people. In this way, democracy asserts and protects the fundamental equality of people. We are equal in that which, when recognised and practically experienced, gives us roots in the world: we are all persons, rational and moral subjects, and as such we have the right to participate in the community, just the way we are, by virtue of natural laws. On this model, natural human laws and rights only make sense when they are a concretisation of an objective order of values. If law and its function of protecting the individual result from a transcendental dimension of the world, if law is erected on a moral foundation, and if morality focuses on, safeguards and preserves the worth of a human person, human and civil rights have a strong grounding. The value of a human person as a subject of life can only be highlighted in this way if the human condition is assumed to be decided by the merciful God of Christianity. The idea that there is an objective hierarchy of values which is a real aspect of 
the world is also largely untenable without the assumption of God's presence, as convincingly argued by Max Scheler. ${ }^{72}$

Of course, the reasoning outlined above can be regarded as speculative and ideological. Nevertheless, I believe it to be an apt rendering of the mainstream, dominant way of thinking in Poland in 1980-1981. The point is that citizenship was defined within a framework in which social thinking - i.e. thinking about the organisation of social life, of life one shares with others - was intertwined with value-thinking and religious thinking. Moreover, it seems that it was the prominence of this, so to speak, transcendent or metaphysical aspect of social life in public discourse and social action that caused the events in Poland to resonate so powerfully across the world.

Empirically speaking, both the strikes in the summer of 1980 and the later developments confirm that quotidian and special, "red-letter" social actions were saturated with a vivid religious subtext and Christian concepts. At any rate, thinking in religious terms and making transcendental reality the basis of everyday reflection are common mental habits among Polish society.

\section{Religion and the Idea of Democracy}

This raises a serious question. If the above interpretation of common, popular consciousness is right, it suggests that the social movement in Poland was founded on an idea of democracy similar to the one which underpins American society. The notion of democracy as revealed in the mainstream of social action strikingly dovetails with the principles which Alexis de Tocqueville considered characteristic of American democracy. The fundamental similarity is that the idea of American democracy is rooted in an order of objective, moral and, thus, religious values.

72 "There can be no doubt that the Christian ethos is inseparable from the Christian's religious conception of God and the world. It is meaningless without this foundation. There have been well-meaning attempts to invest it with a secular meaning which is separable from its religious significance, to discover in it principles of a 'humanistic' morality without religious premises. Such attempts $[\ldots]$ are fundamentally mistaken. At the very least, Christian morality must be tied to Christian religion by the assumption of a spiritual realm [...] This is precisely what Jesus calls 'the kingdom of God.' The precept of love is addressed to man as a member of the kingdom of God. [...] In any case it [the kingdom of God] is conceived as a level of being - independent of the order, laws and values of life - in which all the others are rooted and in which man finds the ultimate meaning and value of his existence." Max Scheler, Ressentiment, trans. Louis A. Coser (New York: Schocken Books, 1972), pp. 106-7. 
"Tocqueville stresses," observes Wojciech Karpiński in his depiction of American democracy, "that in America no one dared propose, as did revolutionary despots in Europe, that anything was justified if it allegedly served society's interests - 'an impious maxim which seems to have been invented [...] simply to justify every future tyrant,'” Karpiński quotes Tocqueville and continues: "The point is that if law confers omnipotence on American society, religion reins in arbitrary ideas and forbids total defiance."

There is a sphere in human interiority that must not be infringed even in the name of the loftiest ideas. "There are religious reasons," Karpiński goes on,

which allow a human being to refuse the demands of the majority and the commands of the most democratic government. [...] Religion is the foundation of individual freedom and of the meaningfulness of collective actions. Freedom of conscience is the basic requisite. [...] Although Christianity did not take part in the exercise of power in America, it played a greater role than anywhere else. Christianity was the cornerstone of civil freedoms. It defined relationships among people and tacit obligations accepted by the governing and the governed. Only those regulative ideas of social consciousness made laws and institutions meaningful. ${ }^{73}$

Like Tocqueville, Karpiński underscores the difference between America and Europe in the social position of religion and churches. He insists that the multiplicity of denominations was essential to American democracy. The separation of the Church and the state also brought about the mutual reinforcement of faith and freedom.

In Poland, the position of the Church has been very special, particularly in recent years. Catholicism conspicuously dominates over all other religions. But it actually seems that the mainstream process of reformist actions was suffused with democratic consciousness, comprised of characteristically American "regulative ideas" of tolerance and freedom of diverse beliefs, including moral ones. At the time, the influence of the Church in Poland was quite unusual, as it was the adoption of a religious viewpoint and an evangelically-inflected interpretation of everyday life that made Poles so free, tolerant and so willing to endorse the varicoloured heterogeneity and complexity of the social world. It surprisingly promoted a spontaneous, mass understanding of the importance of pluralism

73 Wojciech Karpiński, "Strona Tocqueville’a," in Wojciech Karpiński, W Central Parku (Paris: Libella, 1982), p. 65-66. The quotation from Tocqueville: Alexis de Tocqueville, Democracy in America and Two Essays on America, trans. Gerald E. Bevan (London et al.: Penguin Books, 2003), p. 342. 
in the life of a social community. The "working consensus" achieved then was underpinned by respecting the other's right to "otherness." 74

This is not to say that the mindset proved durable. It seems that this facet of the collective spiritual effort has been undergoing a profound transformation since 1981. No matter how it may be explained, the truth is that an essentially disparate trend has set in. This is what makes it even more urgent to produce the possibly most accurate account of the meanings and senses of those events in order to evade the pressures of the present moment while interpreting the not so distant past.

\section{Rootedness in Values and the Diversification of Social Thinking}

I argue that the distinctive facet of the social reformist movement in Poland in 1980-1981 was that both the thinking about the organisation of social life and the actions bred by this thinking developed in a broader, veritably metaphysical perspective shaped by the objective and transcendent recognition of the commonly endorsed order of moral values. Importantly, the moral basis of the social actions undertaken back then was not submerged in "moralising thinking," which prevails today. Back in the day, people sought such frameworks of practical and institutional thinking about the world and such organising forms of collective and individual actions that could foster a social order aligned with and leading people to transcendent values.

The goal was to make human life - the life of all the members of the community - dignified, complete by immersion in the supreme values and guiding to God. To organise their own lives and the life of the entire community in conformity with the order of values taught by religion was a welcome task that answered to people's civic responsibility and care for their own souls.

I believe this way of thinking was ubiquitous and, more often than not, fully consciously practised in Poland at that time. This mindset is well and amply illustrated by the interviews we conducted in Warsaw-based enterprises at the turn of 1980 within a study on the establishment of independent trade unions. ${ }^{75}$

74 Cf. Ireneusz Krzemiński, “Polska i 'Solidarność' - sens ludzkiego doświadczenia," in Ireneusz Krzemiński, Świat zakorzeniony (Warszawa: Wola, 1988); first published in Przeglad Polityczny 6, 1985, and Aneks 40, 1985.

75 See an interview with S in the Chapter entitled "The Rise of the Independent SelfGoverning Trade Union "Solidarity"' in this volume (the passages concern masses which were read at enterprises during the strikes in August 1980): "A mass was read [...]. People had various ideas [...], why that mass was read [...]. The mass was read because many workers are religious [...].Everybody wanted that mass, and there was 
Of course, the religious approach to thinking about values was not the only conceptual model. But, interestingly, a thoroughly secular social thinking, dismissive of any religious justifications, formulated an ethos that essentially dovetailed with the religious one. For this ethos, generally speaking, was personalist, focused on the individual and foregrounded human bonds. It sought a spiritual meaning of life, explored possibilities offered by life in and through our own bodies, repudiated violence and force and rebuked the constraint of moralist norms and formalised values. Both the religious and the secular ethoses defined human life as dignified and fully creditable only if the individual actively expressed his/her beliefs and priorities, let others do the same, looked for the good and sought agreement with others despite differences.

Both ethoses produced slightly different understandings of democracy and emphasised slightly different elements in the civil society agenda. Directly inspired by religion, the former was a bit more authoritarian, demanded selflimitation, required observance of the established rules of conduct and extolled formal and fixed action modes as protection of freedom. More liberal and, so to speak, pliable, the latter model stressed first and foremost negotiations and transactions in social life, viewing the community's life as a vast discussion, a debate in which rules were flexibly proposed so as to adapt to the circumstances at hand and take into account as numerous voices and suggestions as possible. In this way each member of the community could feel that they had an influence on common life and that their opinions, as well as grievances, were listened to by others. ${ }^{76}$

an enormous pressure from the people to hold a mass, actually [...] Why did people need it so much? First, as everybody knows, most workers, like a huge majority of Poles, are Catholic; besides the situation, let's face it, was quite hazardous, and everybody was aware of that. In previous years, strikes were cracked down violently, so in this sense, people better remembered what mattered most to them. Well, what matters most to a Catholic is being close to God above all" (Interview S 3, see pp. ... in this volume). The quotations aptly illustrate religious elements in people's way of thinking and motivations.

76 Such differences were found in the studies on which I rely (Krzemiński et al., Polacy - jesień '80.), where I discuss two religious ethoses and two models of democracy (cf. pp. 187- 91). Cf. also Grzegorz Bakuniak, "My -'Solidarność.' Nowy Związek we własnych oczach” (Ibid., pp. 286-327). In "Polska i 'Solidarność,'” I conclude: "Identification with the Catholic Church and religion took either a more universal, so to speak, 'European' form or a more 'particular,' national form. In the latter, the Church was referred to as the root and a defender of national culture. Universal ethical values were associated with manifestations of Polish identity, and the value of 
Touraine's study also shows other viewpoint differences, which were especially evident among trade unionists in Gdansk, many of whom represented quite discrepant ways of thinking. While the liberal model of democracy was strongly championed, there were also advocates of force and the rule of the majority above "community" and "citizenship." Some workers-activists thought of the trade union as "our organisation" which should vie for the upper hand and be the voice of society. Undoubtedly, the trade unions were treated as "parties," so to speak. This ethos demanded that individuals and minority groups submit to the will of the organised majority for the sake, of course, of common good. Such approach was associated with a sense of risk, the belief in the "established norms" of collective life, authoritarianism and anti-Semitism. Such sentiments tended to fuel ambivalent attitudes to the intelligentsia and a distrust of educated people. Touraine referred to this as a populist tendency. ${ }^{77}$

The rhetoric and attitudes of some social activists indeed resembled what Tocqueville explored as "the tyranny of the majority," which he deplored as the prime internal threat to democracy. ${ }^{78}$ Characteristically, however, Touraine's data imply that the supporters of the authoritarian, or "populist," 79 model were, in practice, nor really inclined to disrupt dialogue and exclude some people form debates and negotiations in advance. Neither were they inclined to attempt any wilful assault on their opponents' unity and destroy them.

The preference for the rule of and individual subordination to the majority was not as extreme as to use the organisation as an instrument of violence in order to

'human rights' and the dignity of the human person were upheld hand in hand with the attitude of 'being my own self' and 'being Polish'" (Ibid. p. 13).

77 Cf. Touraine, Wieviorka, Dubet and Strzelecki, Solidarité (see also Solidarity).

78 Tocqueville, Democracy. Tocqueville writes: "So what is a majority taken as a collective whole, if not an individual with opinions, quite often interests, in opposition to another individual whom we call a minority. Now, if you admit that an all-powerful man can abuse his power against his opponents, why not admit the same thing for a majority? [...] Omnipotence seems self-evidently a bad and dangerous thing. Its exercise appears to be beyond man's powers [...] and I see that only God can be omnipotent..." (pp. 293-4). Tocqueville goes on: “.... king has a power which is only physical, affecting people's actions and unable to influence their will. But the majority is endowed with a force both physical and moral which affects people's will as much as their actions and which at the same time stands in the way of any act and the desire to do it" (p. 297). Cf. also Book IV, Chapter VI: "What Sort of Despotism Democratic Nations Have to Fear" (pp. 803-809).

79 I put this phrase in inverted commas, for I do not find it quite clear. Even less clear is how exactly it should refer to Polish society. 
force the "resistant" ones to submit. Even the activists who upheld authoritarian principles recognised that social negotiations and deliberation were necessary and everybody had the right to speak out and voice their opinions though, admittedly, their hostile attitude to some groups and worldviews impeded agreement. Though eager to be leaders of the community, they were by no means eager to seize leadership by force and escape social control. ${ }^{80}$

This was associated with the tendency to think of society as a community and, therefore, as the agent of legislation. First and foremost, democracy made people feel that society was alone capable of determining the direction in which social life should move, the forms of social actions, the structure of human relationships and what was good and bad for the community.

Solidarity trade-union units faced a number of practical problems. The organisational model and the political ideal which were being forged in practice at the time closely resembled what theorists often refer to as participatory democracy. ${ }^{81}$ The priority of participatory democracy is to include as many community members as possible in decision-making and to structure social actions so as to promote spontaneous initiatives. The emphasis, therefore, is on participation, instead of on control, and on active engagement in the common cause and common life, instead of on the representation and the functional segmentation of life with a view to guaranteeing freedom of action and equal rights. The supporters of the authoritarian model also found the sense of belonging to the community and involvement in its transactions highly appealing. This naturally mitigated their attitudes.

The intelligentsia, in particular intellectuals, characteristically thought of democracy as of an institutional order. Their visions of democracy as a technique of decision-making, as a mode of publicly expressing varied interests, as a principle of bargaining among various social forces and as a way of achieving the social equilibrium or homeostasis very clearly surfaced in the process of building independent trade unions of Warsaw's intellectual circles. ${ }^{82}$

80 I believe that the fraction of the so-called true Poles, with their strongly nationalistic leanings, was the greatest threat to the consensus evolving in Warsaw. It seems, however, that the consensus was not broken then.

81 The model of "participatory democracy" is discussed, for example, by Paweł Śpiewak. See “Demokracja," Powściagliwość i Praca 5, 1984.

82 Cf. Ireneusz Krzemiński, “Jak powstał i działał Niezależny Samorządny Związek Zawodowy Pracowników Nauki, Techniki i Oświaty," in Ireneusz Krzemiński, Polacy - jesień ' 80 . 
I believe this was linked to sociology and sociological standards of thinking about contemporary society. The structural and functional model of society associated with the study of social attitudes underpinned their practices initially, it seems.

This model of the trade-union movement was definitively rejected by trade unionists themselves when the members of the Niezależny Samorządny Związek Zawodowy Pracowników Nauki, Techniki i Oświaty (Independent Self-Governing Trade Union of Scientific, Technical and Educational Workers) decided to join the NSZZ "Solidarity."

\section{Sociology and Social Processes}

The sociological inspiration turned out to be entirely misguided in this case. Sociologists found themselves fully surprised by the developing social process. Despite several studies conducted in the 1970s, Polish sociology was entirely at a loss facing the events at hand. First, most sociologists had not anticipated what was actually going on at all. They had even failed to notice that the former mechanisms of legitimising the socio-political system were crumbling. Second, the conceptual tools and research methods used by sociologists did not help understand the occurrences the were witnessing. The dominant framework of social diagnosis formulated in the late 1970s was clearly useless in identifying the actual elements of the social process. Stefan Nowak's article "System wartości społeczeństwa polskiego" ("The Value System of Polish Society") is an excellent case in point. ${ }^{83}$ Concluding Nowak's research, this "sociological portrait" of Poles posits that Poles' self-reported endorsement of the democratic system goes hand in hand with the common approval of suspending democratic freedom for the sake of "important social goals." Nowak insists that people are deeply attached to egalitarian ideology and negatively assess aggravating social differences (as judged by the criteria of social equality). This involves a declared support for the socialised economy (state-owned industry, especially heavy industry) and increasingly critical views of economic management policies. More importantly, Nowak's findings indicate that Poles are "an uncorrelated society," which means that differences in views and attitudes do not add up to any coherent pattern. The differentiation of views does not depend on the differentiation of social situations. The key components of the social situation, such as demographic

83 Cf. Stefan Nowak, “System wartości społeczeństwa polskiego," Studia Socjologiczne 4, 1979. See also Stefan Nowak, "Przekonania i odczucia współczesnych," in Polaków portret własny. 
factors (e.g. sex and age) and the social position (e.g. education, prestige, income, occupation) are only weakly associated with the attitudes reported in surveys. Religious identification is a poor predictor of the attitudes as well. As a result, society seems a contingent assemblage - a "motley" of sorts. People's identification with family and the nation seems the only spontaneous ordering structure. Family ties, family as a value, national bonds and the nation as a value are the axes around which people's attention and activity crystallise.

Both the events of the summer of 1980 and the explosion of sustained social activity in September 1980 question this sociological portrayal. The endorsement of the democratic organising principles of social life was the only of the elements highlighted by Nowak which could be observed in the process. Otherwise, the events disproved Nowak's major finding that Polish society verged on social anomie, ${ }^{84}$ i.e. the state of sparse and meagre social bonds which are irrelevant in people's lives and do not express either common interests or shared ethoses. Admittedly, social activists were initially preoccupied with building a network of mutual contacts and with establishing social relationships among individuals and groups. Yet, a trade union assembling millions of members could not have possibly come into being within such a short time without a pre-existing network of social bonds and multifarious relations among various, socially distant groups. The portrayal of social identifications as revolving around two remote axes - "at the bottom" and "on top" of the ladder-like social structure - turned out to be misconceived. In all likelihood, the methodological model and theoretical underpinnings of Nowak's research were not suited to identifying and showing relevant facts of the emergent social process.

At that point, another sociological study could effectively help anticipate and understand the events of the early 1980s. In his 1979 study "Struktura społeczna i postawy a grupy ethosowe" ("The Social Structure and Attitudes vs. Ethos Groups") (published only in 1982), ${ }^{85}$ Tadeusz Szawiel claimed that the social dynamics could be usefully explored within other frameworks than the structural and functional model, which was commonly adopted by sociologists and in so-called attitude research. Szawiel insisted that people's desire to found their lives on moral values could be a dynamising factor in social action. He explained

84 The concept of "anomie" was proposed by Robert K. Merton, drawing on Durkheim's theories. See Social Theory and Social Structure (New York: Free Press, 1949), Chapters VI and VII.

85 See Tadeusz Szawiel, "Struktura społeczna i postawy a grupy ethosowe," Studia Socjologiczne 1/2, 1982; and Tadeusz Szawiel, "Social Structure and Attitudes vs. Ethos Groups: The Possibilities of Social Evolution," The Polish Sociological Bulletin 3-4, 1981. 
that people's aspiration to live in conformity with their moral beliefs and to ground the life of their social community in the ethoses they upheld could fuel broad social activity and set the goal of a social movement. On this model, "social energy" could accumulate not so much in groups on top of society's formal structure (i.e. the institutional structure) as rather in "ethos groups," which exemplify possibilities of a life of dignity by the mere fact of being there. Szawiel discussed such ethos groups in Poland and the influence they radiated in the late 1970s: the independent democratic opposition, religiously dedicated Catholic groups and groups stemming from counter-culture.

Indeed, it seems that people from those groups were spontaneously approached for help and counsel when mass-scale social action was attempted. ${ }^{86}$ Interestingly, rather than being expected to lead the action, they were called on to be experts and advisors.

The approach proposed by Szawiel also showed that aspirations to install a social order that met the needs and interests of various social groups and was based on negotiating the rules of the game were not the only vital factor in people's social involvement. Equally important were also aspirations to work out practical principles which developed and enacted moral values. The impact of the ethos groups suggested by Szawiel represents, I believe, quite accurately the mindset common among Poles as outlined above.

Comparing social developments in Poland at the threshold of the 1980s with the pictures of society offered by the sociological studies of the day exposes other inadequacies of social research. Namely, it seems that the dynamics of the developments in Poland were considerably affected by "generational" configurations.

\section{The Role of Generational Groups in the Social Movement}

"Generation" is one of the notions largely abandoned by mainstream sociology. In Polish sociological studies, "generation" is also hardly a significant concept although interesting theoretical insights concerning "generation" appear here and there and sociologist have carried out survey studies of the young generation. ${ }^{87}$

86 In Warsaw, workers involved in the establishment of new trade unions sought help and advice from various Catholic activists and from democratic oppositionists about whom they had heard or read in the official press (see "The Rise of the Independent Self-Governing Trade Union 'Solidarity'” in this volume).

87 In Polish scholarship, the concept of generation has been discussed by Maria Ossowska (“Koncepcja pokolenia," Studia Socjologiczne 2, 1963); Jerzy Mikułowski-Pomorski 
Such choices and preferences follow a general trend observable in sociology worldwide. The "youth revolt" movement made sociologists reconsider the notion of generation, but, so far, they have hardly moved beyond the study of the generation gap, i.e. conflict between the generations of parents and children. Perhaps the theoretical "shift" noticeable in sociology will eventually produce a new generation concept.

As a matter of fact, the experience of Polish society can be relevant to such a future theory. The mass social actions undertaken by Poles clearly revealed generational differentiation. While this differentiation did not actually determine engagement or non-engagement in the collective organisational effort, it was certainly an illuminating factor in a clear differentiation of ethoses and in the system of "active" social bonds. ${ }^{88}$ In other words, generational groups played an important role in the process of social actions. First, they were spontaneous manifestations of respective ethoses, articulated particular values and simultaneously embodied certain modes of thinking and lifestyles. Secondly, they afforded a sense of generational identification and activated real generational ties, which served as the basis for actions and as building blocks for a new network of social relations.

Generational groups are, in a sense, latent groups. The social contacts and the offshoots of the group spirit which are visible on the surface of social life are just the tip of the iceberg which is composed of a vast potential of mutual human bonds and people's sense of community. Generational belonging is very closely correlated with our sense of self-identity and our self-image. The self-image is partly built of symbols of values which we share with people with whom we also share our major social experiences. Hence, a generational group must forge its own ethos or, at least, its own lifestyle, and the formation of such a generational group is linked to stages in individual human development. ${ }^{89}$

(“Pokolenie jako pojęcie socjologiczne," Studia Socjologiczne 3/4, 1968); and Jan Garewicz ("Pokolenie jako kategoria socjologiczna," Studia Socjologiczne 1, 1983).

88 The social movement that arose around the NSZZ "Solidarity" has been studied from the perspectives of participants and witnesses by Mirosława Marody et al. Cf. Mirosława Marody et al., Polacy '80: wizje rzeczywistości dnia (nie)codziennego (Warszawa: Instytut Socjologii UW, 1981; and a 2004 re-edition).

89 "Lifestyle" designates a phenomenon which is, so to speak, "more non-committal" and less binding for the individual than injunctions of an ethos. Lifestyle is also less rigorously defined than ethos, but the two notions are interrelated. For an insightful discussion of ethos, see Maria Ossowska, Ethos rycerski i jego przemiany (Warszawa: IFiS PAN, 1978); for information on lifestyle and related issues, see: Styl zycia. Przemiany we współczesnej Polsce, ed. Andrzej Siciński (Warszawa: IFiS PAN, 1978). 
In my argument, I draw partly on the concept of generation proposed by Jan Garewicz, who emphasises that generational identifications are determined by participation in seminal social events which are experienced together with peers. ${ }^{90}$ Importantly, such an experience must coincide with the moment in individual development when one's self-image, hierarchy of values and representation of society are taking shape. Participation with peers in such an important social event forces the person to side with some views and against other ones and to endorse some values while rejecting other ones. In a peer group which experiences this, a specific system of relations, links and divisions arises, accompanied by a unique manner of assessing reality, which becomes a permanent component of the generation's thinking and lifestyle. In post-war Poland, such generation-forging impulses were provided by participation in dramatic socio-political events, erupting social conflicts and cabinet changes that followed them. Hence, generations were formed around events associated with such dates as October '56, March '68 and June '76. The sense of community, of "social kinship" even, is connected to the necessity to make an axiological choice in dramatic situations.

This process can be viewed as the formation of people's social identities. Social relationships that will develop among the members of a generational group will be permanently marked by a certain camaraderie, even if the individuals side with opposite parties to the conflict. The durability of such generational bonds seems to be essentially boosted by the elites or individuals symbolising the shared generational experience and practically embodying the shared ethos, or at least a given lifestyle. Allegiance to the idols and to the elites reinforces people's identities and makes even latent generational identification a lived experience.

I argue that the social dynamics of the "hot summer" of 1980 and the signing of the Gdansk and Szczecin accords provided a stimulus which activated generational bonds. Of particular importance in the recent process of social transformations were two generational groups: the generation of March '68 and the generation of June ' 76 . These two generations were the fulcrum of the social reforms movement.

90 Cf. Jan Garewicz, "Pokolenie jako kategoria socjofilozoficzna," Studia Socjologiczne 1, 1983. Garewicz defines "generation" as "a group of people whose way of thinking has been formatively determined by the same experience, which will henceforth be referred to as generational experience. [...] Generational experience is acquired in various ways which depend on individual traits and individual circumstances [...] Importantly, for all the people involved in it, it is a breakthrough event in their lives which they cannot erase from memory and which filters all subsequent events for them" (p. 77). 
The two generations are linked to each other. In a sense, the generation of March ' 68 mentored the generation of June ' 76 and were the primary point of reference, in not the model, for them. Crucially, the two generational groups are not symmetrically distributed across the social structure. The March generation form a clearly recognisable social circle within the intelligentsia, without much active resonance in other social groups, workers in particular. The March generation is comprised of people who were students at the time of March events. The June generation is certainly far more varied structurally. It is, basically, a worker formation though it also includes people who were freshmen and sophomores in 1976 as well as some white collars. The generation of June ' 76 is comprised of a fairly broad group of people who stood at the threshold of adulthood during the memorable events in June 1976. That the June generation is so heterogeneous crucially affected the evolution of the social movement. The feeling of generational bonds served as a bridge which helped span blue- and white-collar workers, especially in big and complex enterprises. The sense of camaraderie produced earlier and the "currently" recognised similarity of viewpoints coalesced to encourage the differently positioned members of the generation to renounce mutually negative stereotypes of clerical and manual workers, which were as a rule deliberately reinforced by the enterprises' organisational structure. $^{91}$

The two generational groups had their ethos representatives, with those of the March generation being, obviously, a bit older than those of the June generation.

People who made up these two generations were an inspirational force behind the development of the social reform movement in 1980 as well as eminent opinionmakers in the new trade unions.

Notably, the intelligentsia or (former) students of the June generation powered the establishment of the Independent Students' Association (Niezależne Zrzeszenie Studentów, NZS) at universities. The NZS was developed by the oldest students, who relied on their earlier experiences for models (e.g. protest demonstrations following the murder of Stanisław Pyjas ${ }^{92}$ ), while their younger classes remained predominantly sceptical.

91 I discuss this issue in my "System społeczny 'epoki gierkowskiej," in Społeczeństwo polskie czasu kryzysu, ed. Stefan Nowak (Warszawa: Uniwersytet Warszawski, 1984) (re-edition: Warszawa 2004).

92 Stanisław Pyjas was a student of the Jagiellonian University in Cracow and an activist of the students' anti-communist opposition. He died in 1977 in still unexplained circumstances. While the official post-mortem cited a fall from the stairs as the cause of death, he was and still is widely believed to have been killed on the order of the 


\section{Sociology, Society and Roots}

The major point of my argument above, which all too sketchily outlines and interprets the social processes observable in Poland in recent years, is that social life is incomparably more arcane than "scientific sociology" assumes it to be, because society is neither an isolated being nor an interhuman space where solely physical, material forces are at work.

Social life takes place not only in a natural, physical environment, a setting that makes it "a thing" to be studied. Crucially, social life unfolds also in a spiritual pace, a space of meanings which facilitate - or, for that matter, impede - making sense of the world, deciphering the meaning of life and giving a point to human existence. Although social and shared with others, the spiritual space is essentially internal and concealed. It is bound up with thinking of and experiencing moral values and hinges on axiology.

Simone Weil, on whose insights I draw throughout this text, writes:

Uprootedness is by far the most dangerous malady to which human societies are exposed, for it is a self-propagating one. For people who are really uprooted there remain only two possible sorts of behavior: either to fall into a spiritual lethargy resembling death [...] or to hurl themselves into some form of activity necessarily designed to uproot, often by the most violent methods, those who are not yet uprooted, or only partly so. ${ }^{93}$

The belief that my life is meaningful depends on my experience of "being myself" and "being at home."

The two things are inseparable. The interaction of these two phenomena and these two notions is not simple, for one can remain oneself even if one "is not at home," that is, when one is enslaved and has no possibility to influence one's life. Yet, I can only be myself if I have experienced having my own place and if I endeavour to make myself at home. People's roots have little to do with an idyll, and rooted life is by no means a land of unalloyed felicity, but it always upholds and safeguards people's dignity. As such, rootedness is an outcome of efforts launched and sustained by entire human collectives.

The efforts promote the harmonisation of value orders and planes of existence in which human lives unfurl. In particular, the internal, spiritual, essentially personal and individual order is harmonised with the external, social and communal order. "Every human being needs to have multiple roots. It is necessary

regime. Pyjas's death sparked vehement public protests in Cracow and across Poland. (translator's note)

93 Weil, Need for Roots, p. 47. 
for him to draw wellnigh the whole of his moral, intellectual and spiritual life by way of the environment of which he forms a natural part." 94

If I grasp Weil's thought, the inner hierarchy of values should be understood as an element that ushers human beings into transcendence, into an objective order of values. The inner hierarchy is, so to speak, a compass that helps us move in the right direction and keep in touch with spiritual reality, despite multiple adversities and inconveniences. The social hierarchy as a "practical" and "material" regulator of human life is always merely a crude personification of the order of values, which is more immediately appreciable in our inner reality. However, if the inner hierarchy is destroyed, the social order and the social hierarchy are destroyed by default as well, which leaves people stranded without the sense of roots and joy of life. It is the disintegration of the internal hierarchy - the impossibility to harmonise "the inner" and "the outer" - that uproots the human being. There is also another obstacle on workers' way to culture. Slavery is this obstacle. Weil insists: "The mind is essentially free and sovereign when it is really and truly exercised. To be free and sovereign, as a thinking being, for one hour or two, and a slave for the rest of the day is such an agonizing spiritual quartering that it is almost impossible not to renounce, so as to escape it, the highest forms of thought." ${ }^{\text {95 }}$

Yet, effort can be undertaken to act in accordance with one's own thoughts and beliefs for more and more hours of the day. Effort can be made to restore the alignment between the internal and the external orders of life.

I believe that social processes developing in Poland in recent years have shown that huge human collectives can be guided by quite specific "interests," by the desire to impart meaning to individual lives and to found common life and its structures on values such as human dignity, truth and justice. Even the most "empirical" social experience itself shows that sometimes ordinary people find rather abstract values as palpable and material as a loaf of their daily bread. Contemporary sociology looks for explanations and locates the sources of processes and conscious social movements in what could be referred to as natural conditioning. Natural conditioning includes needs, life exigencies, social interests and natural and quantifiable forces.

Even if this layer is not fully equated with the material sphere of life infrastructure and economic processes, it is at any rate considered absolutely essential. The naturalist worldview of scientific sociology hinders our understanding of events

94 Ibid., p. 43.

95 Ibid., p. 71. 
which overthrow the established order and reverse explanatory patterns, thereby showing that social action is underpinned by far more complex calculations than just counting returns to meet current needs.

Human communities generally do not forget about the material, "natural" foundations of their life and, as a rule, rely on such quantifiable, material calculations. But this is only the framework for a degenerated, desperate and uprooted, to use Weil's term, human life. Societies usually recognise the danger of uprootedness, and people are not passive vis-à-vis the greatest threat to their both material and spiritual existence. The social space, as the life space of human masses, accommodates not only calculations of cost-effectiveness of social energies but also calculations of the meaningfulness of such energies and of the meanings of cost-effectiveness. "But that is not social," observes Weil, "it is a human environment of which one is no more conscious than of the air one breathes. A contact with nature, the past, tradition. Rootedness lies in something other than the social." ${ }^{\text {96 }}$

Nonetheless, the discipline that studies society should take into account human roots and the human need for roots. The study of what Weil calls "the social," the study of social forces conceived as "things," is not enough to depict and understand our world.

96 Simone Weil, Gravity and Grace, trans. Emma Crawford and Mario von der Ruhr (London and New York: Routledge, 2003), p. 169. 


\section{Poland after Solidarity: Social Consciousness and People's Attitudes}

Unexpectedly, Poland of the 1980s stubbornly resists understanding and defies sociological accounts, if an account is taken to mean something more than just a report on survey data. It is a major challenge to put one's finger on and call by its proper name that which one has so profoundly and poignantly experienced as a member of society. Sociological and psycho-social interpretations of social life are strikingly reductive, partial and superficial. We have no adequate theoretical idiom to help us channel and hone our reflection. Nevertheless, I would like to go beyond ordinary, common-sensical observations in order to offer common sense more food for thought.

My other aim is to leave a testimony. In Poland, the time passes in an uncanny and mysterious way. For a country that cherishes tradition and continues to build its identity upon the nation's past, Poland has done a surprisingly poor job objectifying and preserving its social experience. If our lives are to make sense, we are obligated to bear witness in order to help others in their quest for the good and the true.

\section{Social Consciousness}

My major concern in this chapter is to focus on what social life researchers tend to refer to as social consciousness.

The notion of "social consciousness" calls for a clarification. In general terms, I equate social consciousness with whatever people think or could think, given their current knowledge and thinking habits. I define social consciousness here as popularly adopted ways of interpreting the world which determine both people's attitudes manifested in everyday life and the space of discourse, i.e. symbols to which people relate in everyday thinking. Consequently, social consciousness consists of symbolic images of the world which are more or less critically adopted by people and shared with others, and used by actors of social life in mutual communication and explanations of their actions.

The shared symbolic images of the world (interpretations, "expositions," definitions of situations, ideologies) provide a framework for attitudes which the participants in social life tend to spontaneously adopt on an everyday basis and which they can expect from other people in their daily interactions. The spontaneous confirmations and self-confirmations of attitudes expressed in particular 
situations give people a sense of reality and demarcate the perceived community with others. This sense of community is continually confirmed by default and taken for granted "here and now" by an overwhelming majority of social actors, if not by all of them.

Of course, community members can object to "the obvious." But their objections and, even, calls for altering the situation or their own conduct must be preceded by their recognition of "the obvious." The definition of the situation is in and of itself an element of the world. As such, it transforms as it is confronted with "the world" and the lived social experience of people involved in action.

The definition of the situation is comprised of and reflects an ensemble of attitudes which are symbolically represented in the individual selves of community members. Basically, social consciousness is thus understood as the broadly shared mode in which society members interpret their own situation. But this world picture is affected by and expresses more fundamental and more general beliefs about what the world should be like. Coupled with current experience, these beliefs co-determine the interpretive approach to the world's present condition. They become normative, forming, so to speak, the moral roots of changeable experience. Sometimes, they also act as regulators which make change difficult, if not entirely impossible.

In the following, I will outline such a broadly shared image of the social world - the "here-and-now" world - "obvious beyond explaining," prevalent in Polish society in the 1980s.

Any study of social consciousness is a study of transformations in the broadly shared definition of the situation and, as such, has its obvious limitations. Moreover, my aim is to focus on the process involving the broadest group of people, i.e. on definitions of the situation which are accepted "as obvious" by the so-called general public. Sociologists know very well that "the general public" is rarely "general." Yet, when I refer to a "generalised definition of the situation," I mean both the fact that this definition is broadly shared in everyday life and that it as a rule determines people's everyday behaviours. Consequently, such definitions are definitions of the situation which prevail in most cases.

Offering accounts of "social consciousness," sociologists often classify attitudes in various categories. They divide attitudes into "social," "political," "moral," "economic," etc. Such a classification of attitudes can sometimes be useful, especially if it overlaps with defined and specific fields of human activity. I will refer to such categories from time to time, but what matters more to me is a different scheme of the "consciousness content," or human attitudes, one in which they are hierarchically arranged in terms of their degree of generality. Some symbolic images can be regarded as more fundamental - "primary" - because other 
interpretations rely and draw on them. As a rule, some attitudes are explained by other attitudes. Some time ago, Adam Podgórecki insisted that we needed to distinguish "meta-attitudes," which he understood as people's generalised mindsets which ordered current attitudes to the changing world, retaining some of them while discarding other ones, etc. Consequently, there are "upper," "more general" and "abstract" interpretations which enable us to capture the entire field of action and in which we find generalised meanings inscribed in various attitudes of people who act with and relate to each other, as Alain Touraine observes. ${ }^{97}$

I hope to outline such "meta-attitudes," or "upper" interpretations of "primary images," which underpin the structure of secondary, fragmentary and alternative attitudes. $^{98}$

\section{Ubiquitous Politics}

In a paper tellingly entitled "Mieć aby być" ("To Have in Order to Be"), ${ }^{99}$ delivered at a nationwide sociological conference in Cracow, Mirosława Marody described the social consciousness of Poles as organised around three attitudes: 1) a sense of deprivation and impending civilisational degradation; 2) a sense of pointlessness, which leads to questioning the utility of the previous forms of action for goal achievement; and 3) monetisation of social consciousness. Marody understands the feeling of deprivation very broadly, i.e. as a perceived growing threat to civilisation, to people's standards of life and to their moral customs. She argues that his spurs a re-casting of deep consciousness structures linked, for example, to the scale of social prestige, standards of life satisfactions and goals worth pursuing in life. According to Marody, the model of upward social mobility as enabled by and tied to education is losing its significance. Education as such is

97 Cf. Alain Touraine, The Voice and the Eye: An Analysis of Social Movements, trans. Alan Duff (Cambridge, MA: Cambridge UP, 1981), pp. 139-148, 191, 192, 205, 206; Alain Touraine, Michel Wieviorka, François Dubet and Jan Strzelecki, Solidarité. Analyse d'un mouvement sociale. Pologne 1980-1981 (Paris: Fayard, 1982); for the English edition, see Solidarity: The Analysis of a Social Movement, trans. David Denby (New York: Cambridge University Press, 1983).

98 Such a hierarchy is conceptualised by researchers who use the concept of framing and distinguish master frames. Cf. Jürgen Gerhards and Dieter Rucht, "Mesomobilization: Organizing and Framing in Two Protest Campaigns in West Germany," American Journal of Sociology 98(3), 1992; and Robert D. Benford and David A. Snow, "Framing Processes and Social Movements: An Overview and Assessment," Annual Review of Sociology 26, 2000.

99 Cf. Mirosława Marody, "Mieć, aby być," Polityka 6, 1988. 
less and less valued, while material possessions, money in particular, are growing increasingly important. To possess more is becoming the major aspiration of ever broader social circles, and money is becoming the central, if not the only, yardstick of social respect. Building on these observations, Marody insists that consciousness has been "monetised" as money is turning into the basic criterion of people's mutual assessments and evaluations in Poland. Sociological research suggests that "money has invaded the spheres of social consciousness where it was not a frequent guest before. [...] At the moment, sociologists observe what they call the monetisation of motivations, in which success in life is equated with making money rather than with making a social, political or vocational career." ${ }^{100}$ Marody's argument leads to a general conclusion that "in 1981-1985, a shift in the social focus took place from purely political phenomena onto economic ones." ${ }^{\prime 101}$

Marody's fundamental insight is that in the 1980s, i.e. beginning with martial law, the social consciousness of Poles veered from "political concerns" (whatever the enigmatic phrase may mean), which, I take it, had been common before, towards "private concerns," ultimately evolving into "economic concerns." The latter are defined, specifically, as money-making, which serves to achieve personal satisfaction and social recognition.

Marody's findings have generally been received with acclaim. Nonetheless, I believe that the picture Marody has painted largely misses the point. Here is why I think so.

To start with, I do not think that the social consciousness of Poles between 1981 and 1988 can be adequately encapsulated in a single picture. In fact, social "definitions of the situation" have changed a few times since $13^{\text {th }}$ December $1981 .^{102}$ The first transformation was bound up with this ominous date. When exactly the subsequent transformation of social consciousness (as formed in the aftermath of the December'81 events) took place is rather difficult to pinpoint, but there are reasons to believe that it occurred in the symbolic year 1984. If I were to define a single turning point, I would choose the murder of Father Jerzy Popiełuszko and the trial of his murderers, which stretched over the following months. It was then, I believe, that a form of social consciousness was moulded which persisted without much variation by 1987. The autumn of 1987 and, in particular, the beginning of 1988 mark the onset of a transformation process

100 Ibid.

101 Ibid.

102 On $13^{\text {th }}$ December 1981, martial law was proclaimed in Poland. (translator's note) 
which has eluded any accurate description as yet. In this context, we should think of a sequence of developments rather than of one clear breakthrough moment: the release of political prisoners, the referendum on the second stage of economic reforms and price rises. The transformation is still in progress and, as such, it is difficult to define. Given this, 1988 will circumscribe my argument.

Secondly, in total opposition to Marody's thesis, I argue that politics has almost completely pervaded social consciousness and the way people have experienced their lives in this period (and are probably experiencing them as we speak of it). People's popular thinking, including the way they think about their lives and opportunities in life, is nearly fully delimited by, let us call it, a "political consciousness," that is, by viewing life concerns in conjunction with the political situation, the "system," the assessment of the party-and-state authorities and "them" - the regime that governs the country. Almost all important matters in life, therein living conditions, are interpreted in relation to the state and the government, which means that they are defined in political terms. Sometimes it seems that even people's attitude to nature depends on their appraisal of the state and its communist rulers! I will focus on the upsetting aspects of this situation later. The narrowing down of discourse, which is divested of knowledgerelated, aesthetic and, even, psychological preoccupations, is observable both in everyday life with its popular forms of social communication and in higher forms of cultural life and communication within academic, literary and artistic elites. What is more, the same can be said about the religious life of Poles. Scholarship, literature, art, journalism and religion seem to be steeped in ideological thinking, which directly translates each field's specific values and qualities into a defined position - "our" position - on every important matter. Such ideologisation entails that the declared and represented values are "our" values, i.e. on the one hand, we serve them and, on the other, we have a "title" to them. Agentive subjects make axiology part of their identities and, consequently, any axiological doubts about or criticism of their actions are viewed as a direct attack on the more or less honest guardians of these values. Patent in cultural and religious life, such ideologised thinking reveals the ubiquity of politics and, consequently, the instrumentalisation of values. The effect is strengthened by the prominence of the national element in people's self-images and images of the social situation (which Marody entirely overlooks). "National" concepts are emotionally loaded, serve to define the situation and frame what I called above "political consciousness."

In a sense, to evoke national concepts became expedient for entire society in protecting their identity. The politically relevant national concepts were, as if by definition and by default, pitted against "them" - the winners who, despite their 
victory, were unable to strip us of our identity. This fostered the ideologisation of thinking, as it was exigent to show the world and ourselves that the Nation embodied true values and the political failure was only a short-lived triumph of evil over good. In this way, thinking in national terms set the scene for what I call "ideologisation." Still, to answer the question "How does the ubiquity of politics manifest in everyday life and in individual attitudes?" is a different matter.

The transformation that took place in the mid-1980s primarily concerned the definition of the political and the place of politics both in social life and in unique individual existence. In 1980-1981, politics was positively defined by an overwhelming part of Polish society as a result of an extended conceptual and social process. Politics amassed positive existential connotations. Yet in the following years, these meanings changed, and today politics is defined in purely negative terms.

In 1980, political participation meant participation in discussion, in negotiations, in social bargaining, where the development of the entire community and people's own interests were at stake. Politics as engagement in the constitution of the social order was believed to be a condition of individual selffulfilment and of life lived meaningfully and in dignity. The prospect of political participation was highly appealing. Above all, it transformed the self-image of "an ordinary person" in Poland. The right to take part in public life - in decision-making about individual lives and collective life - gave people a sense of self-worth and conferred value on individual existence. Such an understanding of politics produced the unique, existentially elevated tone that resounded in Poland in the Solidarity period. Such mindsets showed in multiple ways and, admittedly, were sometimes counterproductive in terms of effective collective action.

Martial law abruptly broke the emergent new definition of politics which accorded a new meaning to participation in public (social, collective, etc.) life.

The brutal, well designed and carefully executed crackdown on the social reform movement came as an utter shock to social consciousness and new forms of individual mentality, which were deeply transforming and developing at the time.

Politics reverted to its old, menacing self. The shock of martial law was, above all, a moral shock. Force and violence opposed higher values in everyday life, negated the idea of human - social and national - accord and undermined the psychological reality of the shared world.

Violence and malice - that is, "politics" as a capacity and readiness to use force in order to subordinate others - drenched the social space. The shock of martial law was, I repeat, a moral shock: malice triumphed, and the will to 
power surpassed the will of social concord and collaboration. The new sensitivity suffered a blow, and with it also the emerging belief that satisfaction from participation in shared life was stronger that the urge to command others, and that mutual trust was a suitable foundation of social relationships. Somebody ("they") chose violence over the effort of earning recognition; they chose to seize power by force and domination rather than by winning public support and social approval. Despite its moral and cultural resources, society proved helpless in confrontation with violence and force.

We had to understand how it was possible in the first place.

\section{Stage One: Moral Victory and Underground Society}

The psychological shock caused by martial law demanded a new definition and a new attitude. As such, it had two consequences which followed on each other's heels. One of them was a religious - spiritual even - re-invigoration experienced by a huge part of society. The other was the re-defining of politics. Actually, there was also a third effect which abruptly blocked spontaneous individual and social action and, consequently, compelled people to change their life plans and re-direct their life energies. I will analyse these problems selectively, in line with my major argument.

The Solidarity reformist movement largely grounded the idea of society in ethics.

The goal of building civil society can be seen as an aspiration to express universal moral values through giving collective life a particular form, to align social life with the objective order of values discovered and endorsed by people, and to bring principles of social life in agreement with moral principles. The metaphysical dimension of the world, which had strongly informed social action, appeared in a new light in the aftermath of martial law. ${ }^{103}$

Previously galvanising the citizenship attitudes, ${ }^{104}$ religion now offered something else: solace and hope despite shattered individual and collective plans and

103 Cf. Ireneusz Krzemiński, “The Rooted World,” p....in this volume; Józef Tischner, Etyka solidarności (Kraków: Znak, 1981), Etyka solidarności and Homo Sovieticus (Kraków: Znak,1992). For interpretations of Solidarity, see also Józef Tischner, Polska jest Ojczyzną: $w$ kręgu filozofii pracy (Paris: Edition du Dialog, 1985); and Józef Tischner, Polski młyn (Kraków: Nasza Przyszłość, 1991).

104 See "The Rise of the Independent Self-Governing Trade Union 'Solidarity" in this volume; Grzegorz Bakuniak and Krzysztof Nowak, "Kryzys legitymizacyjny systemu w perspektywie doświadczenia życia codziennego," in Społeczeństwo polskie czasu kryzysu, ed. Stefan Nowak (Warszawa: Wydawnictwa Uniwersytetu Warszawskiego, 
expectations. Religion not only provided mental refuge but also helped understand the moral shock and handle the situation mentally. Inspiring freedom strivings and cooperation with others, religion provided a framework in which to understand the unexpected defeat and the brutal breach of the value consensus.

Even though Catholicism is obviously prevalent in Poland, the religious resurgence in 1982-1984 concerned not only Christianity and the Catholic Church. It was also an upsurge of religious sentiments in other denominations and of para-religious investments. ${ }^{105}$ The freshly experienced shock, especially pronounced in terms of morality, powerfully triggered people to embark upon religious explorations in search of the meaning of life and insights into good and evil in the world as such. The recent developments were understood in religious terms: the experience of martial law was an experience of evil. The breach of the accords and promises by the party-and-government partner, the internment of several thousand trade-unionists, the suppression of all social action and constraints imposed on individual activity, the sense of complete helplessness vis-à-vis violence, all added up to the experience of operations of evil, even of the victory of evil in social life or in this world.

Because religious faith - above all Christianity - was embraced as a rescue and a remedy for the shock and suffering, the Catholic Church in Poland acceded to a very special position. Criticising violence and advocating for the imprisoned, the interned and the persecuted, the Church became the only authentic space, "our own" space, a site of community, so abruptly demolished and threatened in the collective's everyday life. The meanings and roles of the Church multiplied, and participation in the community of believers became an unambiguous expression of moral and political allegiances, besides its spiritual and metaphysical dimension.

The definition of the social situation was thus expressed almost entirely in the language of "practical morality." The social world split into two unequal parts. One part included "them," i.e. the government and "people of the regime," in other words the minority that resorted to violence and were by definition "immoral" and "strangers." The other part comprised "society," Solidarity and the

1987), pp. 223-229; Grzegorz Bakuniak and Krzysztof Nowak, "The Creation of a Collective Identity in a Social Movement: The Case of 'Solidarność' in Poland," Theory and Society 16, 1987.

105 Cf. Tadeucz Doktór and Krzysztof Koseła, Ruchy pogranicza religii i nauki jako zjawisko socjopsychologiczne (Warszawa: Wydawnictwa Uniwersytetu Warszawskiego, vol. 1, 1984; vol. 2, 1985). 
Church, i.e. "our own" people who, despite their differences, upheld the shared basic principles.

Faith acquired a tangible social meaning and laid foundations for a unique religious ideology. The victory of "them," shocking and painful though it was, could not be permanent. After all, it was not founded on any profound basis and, above all, it was bred by a disdain for ethics and the sacred. The defeat of Solidarity and the failure of collective action could be construed as a difficult ordeal, but also as a moral victory. People - society - did not betray their ideals and confirmed their resolve to abide by the ethical principles instituted by God and asserted by Christian, European and national tradition. ${ }^{106}$

The further development of events and later forms of social consciousness were determined by two factors. One of them was that various relatively autonomous social forces united around and under the patronage of the Catholic Church. The other was that various layers of social consciousness overlapped, producing a homogeneous, moralist definition of the situation.

The Solidarity reformist social movement presupposed that the state structures could be transformed in a peaceable way. Martial law derailed such calculations and overthrew hopes that the communist regime would re-define its notion of power and, thus, that the state-citizens relations would be non-violently re-cast.

In fact, such hopes were not entirely unrealistic. The signing of the agreements in August 1980 was a good reason to suppose that the prospect of governance based on social approval and reliant on public opinion indeed appealed to the regime. Yet martial law thrashed such hopes.

It was imperative to protest against evil. In the first attempt to grasp that social and existential situation mentally, most people, though smitten by violence, made recourse to new forms of social engagement. This meant, first of all, an unusual proliferation of all kinds of "clandestine activities."

I use this euphemism because only some of these activities could properly be called underground resistance. The catchphrase of "underground activities," 107 which came to be used spontaneously and commonly, also in the official propaganda, perfectly illustrates a banal sociological thesis: in problem

106 In 1997, a reminder is in order that both "morality" and the political meaning of the Church were then interpreted quite differently than now. The Church and the religion it taught were allies of and supported the idea of human and civil rights, which were supposed to be the moral basis for a society of free citizens.

107 The actual Polish word used to refer to such activities was (and still is) konspiracja, which literally means conspiracy, but usually has no pejorative or criminal overtones, as a rule denoting noble and often sacrificial resistance to oppressive forces. 
situations, people define the state of affairs by means of ready-made "symbolic clichés" which are stored in the collective memory. Both sides - i.e. society and the regime - used associations available in the collective memory which, though slightly differently handled, hardly corresponded to what was actually going on. The "attacking," party-and-government side (the government could then be called "the militarised PUWP") understood "underground" endeavour as an outbreak of (also armed) resistance of various group within Polish society against the communists who had gained power after the Second World War. Society evoked "underground" activities as defined by two frameworks of reference: a closer and more entrenched "cliché" of the wartime resistance movement against the Nazi occupiers, which continued in resistance against the regime of the People's Republic of Poland; and a more remote paradigm of national resistance in the period of partitions, with the January Uprising ${ }^{108}$ as its highlight. The association between the Solidarity reformist movement and the January Uprising was very vivid and compelling in the first years of martial law.

Yet the associations marshalled by the two sides were, essentially, inadequate. Both the government's and the opposition's interpretations of "underground resistance" referenced literal rather than metaphorical political struggle struggle conceived as actual combat, therein armed combat, and thus as an organised fight dictated by political goals, whatever moral justification of those goals was relevant to the dynamics of social life.

In fact, the actual "conspiratorial" activity, often dubbed "underground" by the official propaganda orchestrated by the government's press officer Jerzy Urban, was based on entirely different mechanisms and rules. The struggle focused on citizen's rights, and its predominant, if not sole, weapon was civil disobedience. The confrontation of the opposing political forces was, at most, a game in which "society" - "the underground" - engaged with the state's policing apparatus and did not go beyond mass demonstrations, which were staged and joined by largely unprepared people.

108 Toward the end of the $18^{\text {th }}$ century, Poland was overwhelmed and gradually split into three parts seized by the neighbouring countries: Prussia, Russia and Austria (with the third - and last - partition occurring in 1795). Stripped of its statehood, Poland continued divided and without political sovereignty until 1918, when with the end of the First World War it became an independent state again. The period of partitions was punctuated by armed uprisings, which aimed to oppose the policies of the occupying empires and to regain the national independence, with the January Uprising (January 1863 - April 1864) standing out as the bloodiest and most traumatic of those revolts. (translator's note) 
Interestingly, the idea of "non-violent fight" did not develop either, despite some attempts to push social actions in this direction. To talk of underground Solidarity's non-violence movement in the Poland of the 1980s would indeed be an exaggeration. Some exceptions, notably including Wrocław's Orange Alternative and certain initiatives of the Wolność i Pokój (Freedom and Peace), only prove this general observation. ${ }^{109}$

Given this, "underground resistance" was rather psychological, so to speak, and concerned a moral struggle for people's hearts and souls. Paradoxically, the site of "confrontation" prioritised by underground Solidarity was citizenship, and its mode was civil disobedience against the government, which always made it clear that the democratically defined civil rights would not be respected.

In this sense, "underground resistance" meant a nexus of more or less integrated undertakings, many of which were experiments with social action forms in new socio-political conditions, starting from operations of the proscribed trade unions and ending with tentative preparations for armed resistance. The latter, scarce as they were,${ }^{110}$ vividly show how inadequately "symbolic clichés" were to the actual situation they were supposed to illuminate. History offered ready-made interpretations, yet their uninformed application could and did have disastrous consequences.

Ultimately, independent action split into two trajectories: active and passive, with the difference having an impact on individual lives and social consciousness. To grasp the complexity of the situation, this division must be coupled with another one, i.e. the distinction into practical and symbolic activities. The combination of the two criteria renders a tolerably apt typology.

"Active protest" means, basically, taking independent action in which an individual or collective project with a defined, be it only very immediate, objective is developed. This includes a wide range of possible activities, such as collecting information about the situation in the country, helping the imprisoned, the interned and the sacked and their families, distributing foreign aid (which was gradually taken over and institutionalised by the Church), publishing samizdat books, papers, leaflets and appeals for resistance and protest, disseminating independent periodicals and books, manufacturing symbolic objects (badges,

109 Stating that there had been no far-ranging non-violence movement I mean that there were only various forms of collective protest, such as rallies, marches and other public demonstrations of dissatisfaction.

110 A notable example includes a youth group accused of the murder of the People's Militia sergeant Zdzisław Karos in 1982. 
pins, etc.), continuing trade-union activities (collection of fees, organisation of gatherings, etc.), and organising all kinds of meetings (which often evolved into quasi-seminars) and, later, the self-education movement, in which Solidarity's Free University (Wszechnica Związkowa) played a crucial role. No less important than active protest were various ancillary activities, such as making support and flats available for the above-listed operations as well as helping and accommodating the trade-unionist who had gone into hiding. Among active protest forms, I also count participation in public undertakings of symbolic significance to both parties involved, such as demonstrations, $1^{\text {st }}$ May and $3^{\text {rd }}$ May marches, holy masses commemorating the nation's historical and recent events (e.g. anniversaries of the assassination of John Paul II, martial law and, later, the murder of Father Jerzy Popiełuszko) or arranging flower crosses in public places and holding rallies around them (singing religious and patriotic songs, etc.). Other active protest forms also included open letters and petitions, private exhibitions and performances/concerts at private homes and churches.

By "passive protest" I mean various ways of refusing participation in state institutions, both individually and collectively. The latter is represented by actors' boycott of the state-controlled mass media, visual artists' withdrawal from the state-run galleries and other similar participation refusals of entire communities. They represent passive protest alongside millions of individual refusals to get involved in state institutions and/or to observe the newly introduced rules. Of course, the actors' boycott of television was made possible by co-ordinated action of the community's large segment. Particular activities undertaken to exert pressure not to appear on TV belong to active protest forms, yet individual actor's refusals to perform were not necessarily tantamount to any "practical" action. While the entire community as a social group was a significant nomen omen actor on the public, political stage, individual actors did not have to do anything more than people in other institutions who ignored new regulations or just passively refused to perform their roles and worked inefficiently. ${ }^{11}$

Passive protest consisted in refusing to perform certain activities, in continuing to perform other ones against the current orders (such as social workers still helping people dismissed from work and aiding the families of the arrested and

111 In the early 1990s, the protest of actors was interestingly described by Małgorzata Molęnda-Zdziech in her MA thesis. Her numerous interviews with the striking actors corroborate the insights presented in this chapter. Cf. Małgorzata MolędaZdziech, Obecna nieobecność. Aktorski bojkot telewizji i radia w stanie wojennym (Warszawa: Oficyna Naukowa, 1998). 
interned activists) and/or boycotting routine activities and behaviours ("silent breaks" at schools and extremely slow work in production plants).

In such cases, resistance was simply reactive and did not generate any goals for further action. It was first and foremost an attitude which millions of people readily embraced. What passive protest demanded was disengagement from occupational roles, because even if one's labour fundamentally contributed to society's daily life, one anyway "worked for them." And one did not want to work well "for them," because "they" were bound to squander the fruit of one's labour.

Psychologically, passive protest forms resulted in - and were at the same time motivated by - the sense of belonging to the community, sharing the common definition of the situation and involvement in society, which manifested its will and values in active protest forms. More courageous and principled, the minority committed to active protest showed the others a positive image of entire society. Those individuals who were brave, so to speak, for us and on our behalf expressed the collective "will of the people" and the enshrined values. The majority's passive protest helped them assert their bond with the "active" minority in daily life, enact the shared values and, thus, resist the state. ${ }^{12}$

At the same time, bonding and mental mobilisation, especially in 1982-1983, helped society, i.e. ordinary people, build an obvious, albeit invisible, wall that divided them from the regime and "its people."113

Spurred by the need of the moment, ordinary people often performed deeds which made them part of active protest for a while, when they, for example, rescued protesters from militiamen, sporadically made their flats or cars available to conspirators, occasionally bought samizdat newspapers and handed them over to others, etc. This was made possible by the common mental mobilisation, which was sustained by the primary, generalised definition of the situation: this can't go on for long now.

The negative mobilisation of public opinion in Poland and abroad kindled hopes that "they" must finally cave in, accept society and Solidarity's will and seriously take the Church into account.

The assumption that the situation was temporary impacted daily life in a variety of ways. The attitude of passive resistance was expressed in pithy slogans, such as "Winter is yours, spring will be ours" and "When the sun is higher, Wałęsa is nearer." This attitude persevered for two winters and two springs, which was,

112 Cf. Jan T. Gross, Polish Society under German Occupation: The Generalgouvernement 1939-1944 (Princeton and New York: Princeton University Press, 1979), pp. x-xi.

113 Cf. Jarosław Marek Rymkiewicz, Rozmowy polskielatem roku 1983 (Paris: Kultura, 1984). 
of course, surprisingly long. Such an approach, such a mental mobilisation and, consequently, such a definition of the situation could not be sustained any longer.

\section{The Turning Point: Society Disintegrates as “They" Prevail}

The following stage was marked by the disintegration of society and, thus, the decline of Solidarity as a mass reformist movement and a trade union. I believe that the moment which effected this pivotal change in social consciousness came at the end of 1984, in the wake of the murder of Father Jerzy Popiełuszko and events surrounding the crime.

John Paul II's second trip to Poland strengthened the primary definition of the situation as society's "survival tactic" and the positive image of Solidarity as a morally impeccable victim. At the same time, it somewhat undercut the comforting idea that the victory of violence was illusory and the current state of affairs temporary ("You need to ask more of yourselves," said the pope). Survival demanded long-term action and concerted organisational effort. Consequently, the year 1984 saw, a dwindling of hope and, so to speak, a faltering of society. In such circumstances, the national and religious identification of Poles strode to the foreground. More emphatically than before, society framed itself as a bearer and champion of national tradition. Solidarity was incorporated into the historical series of national and liberatory feats as a contemporary variety of the traditional Polish freedom ethos. Paradoxically, this caused everyday statechallenging behaviours (e.g. the boycott of the press and TV, wearing Solidarity badges, etc.) to erode and bolstered the popularity of ceremonial national and religious rituals.

At the same time, however, society increasingly wanted to express resistance to and disapproval of the situation, "somehow" in an organised way. Such social expectations defy clear articulation even today. To put it simply, people eagerly wanted to salvage bonds and to rescue society as a political and symbolic force opposing the victorious regime. Such expectations revolved around underground Solidarity. A study of the samizdat trade-unionist press and texts published then by the hiding leaders of underground Solidarity would probably help define these expectations more accurately. Underground Solidarity defended its unionist identity at that time, sought to represent society insofar as they expressed themselves through the unionist movement and consistently stood up for its democratic and unionist status.

The murder of Father Popiełuszko was a violent demonstration of the regime's hatred of the Church, Solidarity and society. In its aftermath, outraged and terrified people were anxiously waiting "for something" in the belief that 
"something" must be done, that, specifically, Solidarity should do "something." But what "should" actually have been done?

Of course, my answer will be a sociological speculation, even though, as implied above, it can be proved or disproved. A unique act of the will of millions of people, society cannot persist in a homogeneous form without an organisational structure despite its complex grid of internal ties (which, practically speaking, never span the entire population). Such an organisational structure has its practical and symbolic functions. It compiles social expectations, expresses people's interests and aspirations and publicly represents their will. For a representation is both a unique expression and an image - and, thus, a mirror of society. As such, it helps channel everyday practical actions and establish, or at least coordinate, principles of popular behaviours and judgments. In this sense, a representation is a specific vehicle of and an instrument for mustering social energy. Without a representation, be it only a symbolic one (which has no effective means of enforcing obedience), society cannot survive long as a cohesive whole and a psychological and interactive community. This was, emphatically, the case when social actors were forced to participate in the state which, though perceived as antagonistic to society and no longer capable of representing the public, had practical measures to make these social actors obedient. Additionally, the state, which was only a positive point of reference for the minority of "people of the regime," impacted the entire population by controlling all institutions of social cooperation requisite to life. The state actually had at its disposal both violence and an array of rewards to make life far easier and more comfortable to its loyal subjects.

The murder of Father Popiełuszko perpetrated by society-hating state functionaries helped the state re-claim at least some of its power to impact society, if not to represent it.

With no special representation of its own, society can hardly face up to its opponent - the government that controls the state, though being, sociologically speaking, a social minority. Without a representation, society cannot "speak in one voice." For this reason, the murder of Father Popiełuszko triggered a surge of expectations concerning the social representation that could enable society to "address" and confront the opponent on an equal political and systemic footing. Until then, dissent had been chiefly moral and predominantly channelled by the Church.

Even though a man of the Church was murdered, the Polish Catholic Church did not act as a purely political agent, as the state's equal and a contestant against the government in power. Had the Church played this role, it would have risked undercutting its political significance and, even, undermining its social 
structure. Importantly, the Church's socio-political relevance was founded on the fact that it was superior to the state in one sense and completely independent of it in another.

Without a doubt, both Solidarity and the Catholic Church would necessarily have had its representatives in the imaginable social representation expressive of society's expectations.

Of course, such a representation of society never came into being, while the state and the government gained a lot by having Father Popiełuszko's murderers arrested, publicising the regime's actions and then ensuring a wide media coverage of the perpetrators' quick trial.

One of the major gains was a certain blurring of the previously clear-cut society-state opposition. This was effected by undermining the identification of the state with the government in power. General Jaruzelski's cabinet took action against its own officers. "They" prosecuted "their people." Whatever the assessment of the trial of Father Popiełuszko's murderers and whatever the intention of the party-and-state authorities therein, the fact was that the killers were indeed sentenced for the crime. The state asserted itself against the current interests of "their people" and displayed willingness to observe, partly at least, general human norms and the principles of justice.

A detailed sociological and legal study of the case could perhaps produce a different picture of the situation. But it is not the point. The point is that a certain social vision was generated which affected people's thinking and conduct and, though vague and wobbly, fostered an approval of the state the way it was.

What the party-and-state authorities did in the wake of Father Popiełuszko's murder represented an interesting social action. The aim was to encourage people to believe that the regime wanted to rule justly, while re-asserting the government's positive power and adamancy. The mutual hatred of society and the regime's people was supposed to be tempered by crafting an image of a strict and autocratic, yet fair government.

Still, the political spectacle was not fully successful. The state could have benefited far more from the trial of Father Popiełuszko's murderers with all its trappings (such as the statements of the judges, commentaries of the cabinet members, etc.) if only the enterprise had been more consistently implemented and suggested more openness.

Soon after the trial, an attempt was made to institute a tolerably credible social representation within the state. The attempt failed even though a body called the Social Consultative Council (Społeczna Rada Konsultacyjna) was eventually established. 
The difficulties in forming the Social Consultative Council and the purely sham nature of the institution (in which it resembled the earlier founded $\mathrm{PRON}^{114}$ ) raise questions about the state's recovery of some of its "power to command" entire society, which was posited above.

Generally, the social sentiment was that the state was "not ours": the state did not express society's aspirations, needs and interests, taking care chiefly of "their people" and expressing the will of the government (of the regime, of "them"), rather than the "will of the people." But in critical situations, "they" were prepared to exact justice on "their people." Admittedly, "they" demanded subordination and obedience, but they also expected "their people" to be disciplined and, minimally at least, abide by the rules of law and morality.

The positive political message embedded in the trial of Father Popiełuszko's murderers could indeed justify a change in attitudes, which had already been underway for a while, as a matter of fact. The argument above only outlines what I believe to have been the justification which the popular social consciousness used to construct a new generalised definition of the situation. Negative elements prevailed in that new definition because although the state proved ready to punish "their people," the general public did not assume it to restore the rule of law in Poland. Rather, it implied that the state was willing to respect the commonly endorsed, fundamental rules of justice and morality; by the same token, the government, or the regime, displayed readiness to control immorality and lawlessness within their own ranks. This promised some degree of protection against the arbitrariness of the apparatus of oppression. However, the social expectations were not met as no representation of "the will of the people" came into being. As a result, a new attitude took hold in society: the negative acceptance of the state.

People only rarely embrace a thoroughly negative account of their situation in life. That is why a positive element was needed to produce a new definition of the situation though the definition was basically and intrinsically negative.

\section{The Church as a Substitute of Society: The Devil in History}

The new definition of the situation was founded on the simple conclusion that "we need to submit to 'them' because 'they' have the power." Its consequence was that, first and foremost, the public abandoned the civic aspirations which had

114 The Patriotyczny Ruch Odrodzenia Narodowego (Patriotic Movement of National Rebirth) created in July 1982 (and dissolved in November 1989). (translator's note) 
underpinned a symbolic society contesting the state form in place. Did that in and of itself mean an appreciation of the state and the government?

The situation was thoroughly paradoxical, in fact, since the realisation that "we need to submit to them" did not entail any positive recognition, at least not in the sense of any real legitimisation of the regime, an insight shared unanimously by all sociologists and even acknowledged by the propaganda. ${ }^{115}$ Defeating Solidarity and society, the state did not win supporters. What happened instead was that individuals and groups started to develop their personal, egoistic adaptive strategies and stopped responding to the situation together and in solidarity with others.

Adaptive strategies should be viewed dynamically as being developed in stages by individuals and collectives. In the first phase, "negative adaptation" involved passivity and withdrawal from public life, which prompted a further decline of work ethos, going through the motions of social roles and the focus on family matters. This only aggravated social atomisation.

Another consequence was that the Catholic Church was ascribed the new role of a representative and a substitute of society. Solidarity's ideals of the new social order turned out to be impossible to implement, because "they" did not allow that, while "we" - society, nation - were not strong enough to defeat "them" (at least for now). Because these ideals were rooted in traditional Christian ethics and because the Catholic Church was a champion of social justice and human dignity, it became society's refuge and mainstay. The Church was the only common, public site where people could be themselves, that is, behave and present themselves as their identities dictated. Consequently, since no other symbolic and organisational form was available, the Catholic Church - as an institution and, also, as a community - began to function as society's representative.

In other words, society took shelter in the Church, while the Church became society's protector in solidarity with the oppressed. This emphatically brought national sentiments to the fore. At the same time, the national was interpreted as "the Catholic," with the Polish nation embodying, so to speak, the universal system of Christian values. At the same time, towards the end of martial law and further on, society started to frame itself as a community of believers and a national church opposed to "them": atheists, Marxists, communists, the

115 "Legitimisation" is one of the issues which are most frequently addressed in sociological research and theory. Cf., e.g. Gzegorz Bakuniak and Krzysztof Nowak, "Kryzys"; Włodzimierz Pańków, “The Roots of 'The Polish Summer': A Crisis of the System of Power," Sisyphus. Sociological Studies 3, 1982. 
government and "people of the regime." In such circumstances, a moralist and metaphysical "diabolic" interpretation of events spread as the Church acquired a new political significance and power. Residing now in society which united in and around the Church, the strength of the Catholic Church was considerable enough to make the state acknowledge the Church and seek a settlement with it. After Father Popiełuszko's murder, bargaining started in order to establish the principles of mutual relations, delineate spheres of influence and define scopes of control.

The Church's political and religious functions were impossible to distinguish in some circumstances. As soon as society, including both the silent majority and the political elite led by the Solidarity-affiliated opposition, had been incorporated within (or at least joined) the Church, the Church as an institution became the nation's representative, retaining its institutional and symbolic independence. This afforded double possibilities. Namely, on the one hand, the Church functioned as society's - or, rather, the nation's - representative, engaging in a game of influence with the state. On the other, the Church was the protector of society, the nation, the opposition, briefly: Poles in Poland and abroad, and could mediate between the regime and society (as well as between the state and the world or the state and the nation). Because the protector-and-representative in one wanted to shield people, the Church willy-nilly had to play a political role and negotiate with the state. The best intentions notwithstanding, this led the Church into a risky territory. Representing society and, consequently, defining itself as an opposition against the regime, the Church at the same time negotiated with the state and engaged in a political game with "them," which demanded splitting the nexus of common interests. It demanded dividing the interest of the Church as an institution from the interests of society, Solidarity and social opposition groups. The political game threatened to demarcate the religious, moral and national domain as subject to the Church and severed from the rest of social life as subject to the state.

1987 witnessed a conspicuous campaign around a family education textbook. Falling within the sphere of morals, upbringing and family, which were subject to the Church's secular authority, the textbook was fiercely objected to by the Church and, consequently, withdrawn from schools by the government. What was a victory for the Church was, simultaneously, a defeat for society and stamped the loss of autonomous social subjectivity. The domain of morals and educational ideals which form the core of cultural models was seized by the Church and made part of political bargaining. People lost the right to speak up for themselves and, worse perhaps, rational discussion on morals and education proved entirely impossible. 
An important factor in this context was the "besieged fortress" syndrome, which is one of the most characteristic deep structures of Polish culture, as convincingly argued by Marcin Król. ${ }^{116}$ Disputes and conflicts within society, in particular within the Church as society and the Church as nation, were deemed highly unseemly, and they needed to be muffled in time to prevent an internal disintegration which would only benefit the enemy. Consequently, societyturned-nation entrenched itself, so to speak, in the Church's ramparts. The Church became a national fortress, and even its critics, themselves within the walls of the fortress, had to recognise the authority of the clergy, the stewards of the Church as an institution.

As a result of the union of society, Solidarity and the Church, political discourse was almost entirely identified with moralist discourse. Moralist speech is the Church's natural language, and it imprinted itself on the entirety of political discourse and consequently on the modes of political action as well. While moralist speech initially strengthened the Church, society and, above all, the Solidarity-affiliated opposition, in the long run this high-brow speech failed to translate into lucid, everyday, political rules and socially enforced principles. As such, it became merely ritualistic and superficial. As a result, the image of the world burst into two parts: an immoral everydayness (or "this sinful world") and a religious-national sublimity, which came in two varieties: a supplicant and penitential one ("we must cleanse ourselves of the sins of everyday") and a moral and grandiose one ("we are a faithful though sorely tested and oppressed nation").

The fragmentation of the world image was associated with what was called above the diabolic interpretation of the events, which amply deserves a sociopolitical study of its own. Namely, a third important factor in the forming of the negative definition of the situation was the image of "them" - "people of the regime" or "people of the state" - against whom one was completely powerless in daily life.

"They" comprised not just General Jaruzelski's cabinet, but above all the Soviet Union. The powerful USSR served to justify inaction and the surrender of social and personal aspirations. In 1984-1987, popular consciousness came to rely on a trope which the official propaganda and Prime Minister Mieczysław F. Rakowski had utilised skilfully since the imposition of martial law. Specifically, the Soviet Union represented the most important "them": that the USSR would not allow democratic reforms in Poland, instead backing the communist regime, had been incessantly reiterated. Ultimately, the USSR's military power validated

116 Cf. Marcin Król, Podróż romantyczna (Paryż: Libella, 1987). 
the necessity to submit - in this world, in daily life - to the "party-state" and to give up on the ambition of social and national self-determination.

A religious, or metaphysical, reading of politics spread in which the USSR, its ruling communists and Poland's regime "represented" Satan. Of course, such thinking was fuelled by the murder of Father Popiełuszko and President Ronald Reagan's famous speech in which he called the USSR the "evil empire." Both the USSR and the Polish communists, who ruled the country and propagated atheism, were viewed as enemies of God and, consequently, servants of hell. Helpless against them, common people had to relinquish their aspirations and could save themselves, their souls and their identity only within the Church. Devotion became a civic duty as a way of asserting identity, national belonging and human decency. In time, displays of devotion became ever more ostentatious as the daily compromise with "the powers of evil" grew deeper and deeper.

The upsurge of the diabolic interpretation of the socio-political situation unexpectedly gave the regime an advantage as the Church and society could easily be accused of flouting the spirit of Christianity by the "diabolic" branding of atheists, Marxists and communists. Jerzy Urban, the government's press officer, resorted to this argument on several occasions masterfully, if cynically. This compelled the Church to moderate its position somewhat and, as a result, diluted the interpretation of social reality. Since no accurate, judicious language was coined to describe the current situation, the tempering of the moralist interpretation bedimmed the image of "what is going on" in the population's popular thinking.

The authorities of the party-state deliberately used the national framework of reference to produce a picture of a covenant with the Church. In the official propaganda, especially on TV, the national, so to speak, image of the government was being crafted with considerable consistency. The national and religious stratagems were perhaps best visible during John Paul II's third pilgrimage to Poland. The impression of the actual and alleged collaboration of the ecclesiastic bureaucracy and the party-state's bureaucracy was so overriding that many social groups were deeply confused. At moments, the Polish government could indeed pass for personal friends of the Polish Pope. The official propaganda sought to fabricate an image capable of convincing people that, even though lacking social legitimation, the government was indeed "our government." After all, it was a Polish government, and Poland neither had nor could have any other one. I believe that in 1988 such an effect on the popular consciousness of many social groups in Poland was achieved.

Fourthly, as martial law was lifted, small entrepreneurship began to burgeon. The development was promoted both by dissent against the state (i.e. the 
preference to "work on your own account" or "for a businessman" rather than "for them" 117 ) and by the state's policies for boosting the economy, first of all agriculture (the years 1983 - 1985 were good for farmers). The legislation that provided for the rise of private businesses was enforced by economic exigencies and social pressures. Given increasingly more opportunities throughout the 1980s, private entrepreneurship was controlled both formally and financially (through taxation, rationed supplies and administrative constraints), yet grew dynamically and ever more robustly. However, despite indisputable profits and successes, individual entrepreneurship, especially if legal, was initially a negative experience. Even if prompted by dissent against the state, private businesses had to go along with compromise and corruption as without corruptive collaboration with various state agencies no private business was practically able to operate.

Most people in Poland found private entrepreneurship far less important than half legal, if not entirely illegal, trading abroad. It seems that millions of people were involved in it, engaging in commerce during what formally passed for tourist trips. The commerce was very primitive and small-scale, yet it required at least a show of subordination to the "state" as the passport became one of the most precious and coveted goods. One could not refuse to submit to "them," lest "they" refused one the passport. Apparently, nothing could be done about it, and people had to obey the state.

As a result, society's disintegration progressed, and the ethos of honest economy and fair business decayed. People focused on quick profit (before "they" levy taxes on the company or forbid travelling), and their economic thinking prioritised egoistic (at best family-serving) outcomes and consumption instead of long-term investments, while private interests came to seem unrelated to, if not entirely incompatible with, the public good. All this ultimately exacerbated social differentiation and atomisation.

In this way, the generalised negative definition of the situation was formed in Poland, enhancing the appeal of temporary or permanent emigration as an attractive and active alternative.

\section{The Negative Definition of the Situation: "People Don't Matter One Bit, Only Force Does”}

The negative definition of the situation can be succinctly summarised as "Nothing can be done the way it should and the way you want to, because 'they'

117 Cf. Ireneusz Krzemiński, “Nowa generacja”, Kontakt 55, Paris 1986, pp. 60-1. 
have the power." The conclusion that "people don't matter one bit" became the axis of a comprehensive ensemble of attitudes which contributed to that negative definition. The slogan "nothing can be done because people don't matter one bit" generated a new image of the world and a new concept of individual social identity.

The belief prevailed that whoever wielded force had the upper hand in the world. Force determined who was right and how the world was organised. If one did not have enough force and courage to oppose violence, one had to submit to the winners. This change was deeply consequential. It spoke to a scepticism about the ideal of civil society, which affected even the ideal of democracy, even though the latter was still invariably professed in surveys. Democracy ceased to have unambiguously positive connotations and evoked ambivalent responses.

The image of the world ruled by force, a world in which submission to those who had the upper hand was inevitable, was not entirely homogeneous in popular consciousness. In daily life, the negative definition of the situation had a highly distressing ring. Inscribed in it were threat, humiliation and fear. This may be why the image of the world it produced, rather than being stable, fluctuated, even though its foundation was fixed and commonly shared by the upholders of the definition's different variants. These variants incessantly shifted and circulated as if people continued to swap and re-configure ready-made components of the general definition of the situation. Having embraced the negative definition of the situation, popular consciousness seemed to wrestle with itself to find a constructive way out, being at the same time trapped - enclosed within the negative horizon. There was no reason to reject the fundamental negative insights resulting from the division of the universe into the "ideal eternity" and "this sinful world of mortality." All thought processes seemed to revolve within an enchanted - and at the same time vicious - circle: elements of the definition of the situation continually rotated, but their movement was only illusory. The new accounts included the same components, even though different people composed them into new interpretations. I call this highly interesting phenomenon a fluctuating world image and discuss it in more detail below.

The core of the definition of the situation was double-layered. One layer involved the observation that Solidarity and society - the "we" who wanted to reform the world and align it with the civic ideal - had failed. People had been very naive to believe that "they" - firstly, the USSR and, secondly, the Polish communists - would consent to the reforms. The power of the USSR was far too formidable to overcome. Fighting "them" did not make sense as it was "doomed 
to failure" in advance. The diabolic interpretation of the Soviet power effectively bred a sense of helplessness. ${ }^{118}$

Helplessness and impotence were reinforced by a general unwillingness to put up a fight and to resist violence actively. Social consciousness perhaps made a virtue of necessity, falling back on the Christian justification in which killing was condemned as immoral. Violence could not be countered with fight. The justification was underpinned by the memory of wartime experiences ("Would you like yet another war?"). This prompted the assertion that "life is the highest value," which was identified with Christianity.

The other layer of the definition of the situation was deeper and, I would say, more pessimistic. Solidarity and society had assumed that a good social order could be built and that politics and social life could be based on human rights, solidarity and cooperation. They were proven wrong as an order had triumphed in which some people could and did rule others. This implied that in order to institute a certain order in the social world, one needed to seize power even if that order was an ideal cherished by many people. By the same token, social consciousness practically abandoned the civic perspective in which all people had an equal right to define rules of life and principles of governance together.

As the interviewed head of an CRZZ Enterprise Council said, "there must be somebody in charge of the whole thing." 119 Being in charge of the whole thing, by definition, meant the exercise of power and commandeering, i.e. making decisions for one's subordinates and exacting their obedience. This is the reason why the pronoun "they" started to be used also to refer to Solidarity. "They" - i.e. Solidarity - also wanted power and, as such, sought to impose their own order. Accepting that "the world is ruled by force" prompted another change in the social understanding of politics. Politics came to be seen as a site of a struggle for power, that is, for commanding others. This change deeply and, in my view, pessimistically affected social life and the totality of social transactions.

The definition of the situation was, nevertheless, problematic. It bred two gripping questions. One of them was: "How can this image of the world be reconciled with religion and allegiance to the Catholic Church?" The other was: "How can

118 Symptomatically, popular consciousness only poorly registered the USSR's failure in Afghanistan. Independent publishers and oppositional political thinkers did not devote much attention, either, to the Soviet army's withdrawal from Afghanistan and the long-term relevance of this fact.

119 Ireneusz Krzemiński et al., Polacy - Jesień '80. Proces powstawania niezależnych organizacji związkowych (Warszawa: Instytut Socjologii UW, 1983), p. 239; see "The Rise of the Independent Self-Governing Trade Union 'Solidarity'” in this volume. 
the rule that 'force rules the world' (comprehended as 'somebody must be in charge of the whole thing') be reconciled with the image of the West, especially with the stereotypical image of the US as the land of plenty founded on freedom and democracy?"

Different answers to these questions produced different versions of the definition of the situation. I outline them below, by necessity, merely cursorily. For in this definition of the situation only the emotional undertone was homogeneous and vivid, resulting from the obsessive reiteration that "nothing can be done," "they won't let it happen" and "people don't matter one bit." At the same time, the definition itself was unstable in intellectual terms as new ways were invented to conceptually make sense of the experience, even though the same statements were repeated time and again.

\section{Variant One: Conformist Harmony}

In this variant, the image of the world was dictated by conformity to "the events at hand." In the religious version, this meant assuming that whatever happened depended on the rulings of Providence. If the winners won, it apparently had to be so, since our good Lord ruled the world after all. The tension between the world ruled by force and violence and the religious ideal of love and ethics in social life was considerably alleviated by specific personalism: that various people, some of them of "evil nature," came to power was a general rule, even among the clergy; some succumbed to evil while others did not. because some were worse whereas others were better people.

The Church was the highest and ceremonial authority. One needed to be part of the Church, because everything depended on our good Lord who would judge people in the afterlife. At the same time, one needed to "render to Caesar the things that are Caesar's." The verse from the Gospel was erected into a general principle of conduct, so there was no reason not to submit to the party-state. If they governed and were Polish, one had to yield to them. Nonetheless, there was no reason to condemn Solidarity and the underground movement as their intentions were good. The Church should not "meddle in politics." The most important thing was to live a decent life, i.e. not to steal, to comport oneself morally, to start a family and take care of them, in brief: to do exactly as others did.

The ecclesiastical-national identification encapsulated in the ideal of a decent human being justified the view that "life is the supreme value." It was human duty to surrender humbly to the circumstances, therein to the winners. Fight could lead to bloodshed, while killing was expressly forbidden. The meekness inscribed in this variant is best illustrated by the pictorial Polish proverb "a 
humble calf will feed from two mothers." ${ }^{120}$ And, as a matter of fact, it was more about feeding than about humility.

\section{Variant Two: A Manichean Drama with Messianic Elements}

This variant was founded on a dichotomous picture of the world, split into "good" and "evil," "the harrowing everydayness" and "the desirable order of life," and "mortality" and "transcendence." In its religious version, the tension between the mortal and the transcendent, which was somewhat alleviated in variant one, was considerably enhanced. Basically, human life in this world wallowed in sacrifices, unfulfillment and a necessary surrender to the forces of the "world," i.e. the Satan active on earth. As such, life was sinful and replete with suffering. However, if people, sinful though they were, were also pious, they could count on the forgiveness of sins and a reward in the afterlife. Consequently, one could expect neither "the world" nor society nor oneself to attain the ideals of a moral and happy life on earth. People should strive to live in conformity with moral rules, but they are weak, sinful and helpless against the organised power of violence. This religious, dichotomous image of the world generated a unique social form of the Jungian "persona." ${ }^{21}$ Namely, it more or less deliberately referred to the cliché of Poles as victims - Poles as suffering oppression for the sake of higher values, devotion and the fight for the national independence.

Now, the "oppressed Pole" had become a Pole victimised by communism. The persona of the oppressed encouraged feelings of entitlement and, at the same time, spread the belief that the suffering borne by Poles was messianic, as they fought for "our values and yours."

The upholders of both more and less religiously inflected versions of this variant of the definition of the situation accepted that it was necessary to come to terms with this mortal world. It was imperative to respect life and succumb to violence, yet the nation could not forget about their calling.

In this framework, society faded entirely, transmuting into the Suffering Nation. This was the basic structure of identification; this was the supreme and broadest collective self of "us." Appropriated as another iteration of national uprisings, Solidarity came to invite ambivalent appraisals. In positive terms, the defeat was a sacrifice and a moral victory over "them." In negative terms,

120 Polish: pokorne ciele dwie matki ssie, meaning roughly "humility will get you anywhere." (translator's note)

121 Cf. Carl Gustav Jung, Two Essays on Analytical Psychology, trans. R.F.C. Hull (London: Routledge, 1953). 
Solidarity was reckless and failed to salvage and to implement the nation's sociomoral Catholic ideals.

The variant came in many different versions, each of which invariably pitted "us" against "them," stressing the diabolical interpretation of the situation and the world's dichotomous nature.

The moralist attitude came to the fore unlike in variant one, which emphasised the acceptance of "things as they were" and defined "decency" on the micro-level of individual conduct within the closest social environment. Variant two was different as the dramatic tension between this sinful world of mortality and the eschatological ideal generated strongly loaded images of good and evil, blackand-white interpretations and a zealous pressure on the fulfilment of moral obligations.

More secular versions of this variant of thinking were similar in projecting a future victory of "our national ideals" as a reward for the loyal cultivation of values. Society's memory - the national memory - would preserve our struggle, and our moral refusal to bow to evil would be appreciated in times to come. The effort would bring forth fruit some day in the future.

This account of the variant slightly downplays its Manichean undertone of the tussle between good and evil. However, the moralist sense of entitlement mentioned above resulted from the perception of the world as a playground of the forces of good and evil. At the same time, it channelled people's alliance with good, which was invariably, though in different ways, located in the nation.

\section{Variant Three: Egoistic Escapism}

Escapism does not have to designate an active escape or turning back from life. Rather, it implies a conscious withdrawal into one's own world and the abandonment of public life and public concerns. "One's own world" is not so much another culture as rather the private world, where "private" does not necessarily equal "individual" or "personal" and, certainly, not "lonely." In this context, privacy rather means enclosure in one's group, community or bunch, which abide by their values and, though embedded in a broader world, express their désintéressement in the rules which this broader world follows.

The broader world is where "they" have won, and it does not make any sense to strive to change this situation. One must first and foremost "be oneself," that is, mind one's own business and attend to one's own matters without looking back at society. Of course, one must take others into account, but one also has a right to act as one's nature dictates, i.e. associate with the like people to support each other and facilitate mutual satisfaction. The world is always governed by 
some rules which are neither quite right nor quite wrong, but politics is basically an evil, dirty and immoral business. Even the Church as a political actor makes mistakes, but they are a "normal" thing and, as such, should not be abhorred. The Church is founded on religion, and that is crucial. "They" - the communists in power - are egoists as any other human being. "They" are evil, and that they govern is the country's and the nation's a disaster, but after all everybody has their weaknesses and sins, so they deserve some leeway.

What in variant two was a radical tension between eternity and this sinful world of mortality, between the ideal and the quotidian, between the sacred and the profane is diluted in variant three into an unending chain of dichotomies which render a diversified image of the world. The world consists of very different people who are, nevertheless, predominantly guided by dedication to need fulfilment and egoistic pleasure-seeking.

This variant very strongly opposes practical moralism by insisting that, first, phenomena and motives are complex and, second, some good and some evil can be found in all people and in all actors of social life. The relativist stance inscribed in this variant of the definition of the situation is well captured in the rhetorical question "Can we really judge the situation unambiguously?" The relativism is tempered a bit by allegiance to the nation and religion, but the religious version of the variant, somewhat resembling variant one, compartmentalises experience into various segments which are ruled by entirely different principles and instructs to "render to Caesar the things that are Caesar's; and to God the things that are God's." Religious devotion and the endorsement of moral commandments do not entail here either an uncritical and conformist identification with the Church nor thoroughly personal beliefs independent of the Church.

Occasionally, this variant of the definition of the situation was a stimulus to go abroad, yet rarely to emigrate without any prior preparations. Life in Poland could be attractive and personally satisfying for those who had enough hard currency and could travel the world. The variant of egoistic escapism was very often embraced by people who constructed their "private world" upon intense and profitable contact with the world.

\section{Variant Four: Desperate Dissent}

The commonly repeated "It's impossible to live here anymore" best conveys this variant of the definition of the situation, which tends to propel desperate decisions, such as sudden escapes abroad and/or unprepared emigration. Alternatively, it breeds self-destructive behaviours and substance use in search of "another world." While the previous variants locate the causes of the negative 
situation and seek the means of relief outside, this variant agglomerates all negative aspects of life that "target" the human being, without offering any counterbalance to them.

Generally, it is associated with resenting God, the world and people. It involves abandoning religion, or at least the Catholic Church, as well as Solidarity and society, which failed to uphold their ideals. Reality is nightmarish and/or absurd. The attitude that results from such a definition leads to interrogating transcendence, fighting God, quarrelling with the advocates of humanism and moral ideals, denouncing the current form of the world and despising people's current conduct.

Often the variant is not carried to such extremes, targeting not so much God and religion as rather social forms of worship, which fall short of the moral ideal. The triumph of evil in the world and one's own enslavement fuel an individual quest for God and meaning of life along new ways, which stray from the commonly trodden paths and, especially, from the national tradition.

In another version of this variant, the old tradition is contrasted with the current debacle. In this version, the nation is framed as entirely conquered, demoralised by the system and self-debasing. Society, often associated with the nation, is assessed in as pejorative terms as "they" - the state, the system, communism (and the USSR, of course) - are.

This often goes hand in hand with a negative account of Poles, who are described as dirty, sycophantic, petty-minded drunkards and haters with no honour. This basic inventory of Polish vices is, naturally, open to various modifications.

In this variant, the individual is placed in a hopeless position and can only rise above it (and, sometimes, above others) by renouncing any false illusions. This engenders social and mental isolation, while the definition of the situation, which, as such, describes alienation from life, fixes this alienation itself.

Consequently, self-defence mechanisms are activated, and the individual fashions him/herself - and possibly his/her loved ones - into a fortress besieged by the hostile world. Unlike in variant three, the individual walled up in the fortress of the self feeds on misery rather than on pleasure.

\section{The Polish Modes of "Escape from Freedom"}

The ensembles of attitudes that founded and were encouraged by the definition of the situation lend themselves to various theoretical descriptions. Below, I interpret the variants of the definition of the situation in terms of Erich Fromm's concepts. ${ }^{122}$

122 Cf. Erich Fromm, Escape from Freedom (New York: Henry Holt and Company, 1994). 


\section{Variant One: Conformist Harmony}

This variant of the definition of the situation is likely to produce a psychological meta-attitude which Fromm called "automaton conformity." Its important feature is "pseudo thinking": "[T] he problem is whether the thought is the result of one's own thinking, that is, of one's own activity; the problem is not whether or not the contents of the thought are right. [...] The pseudo thinking may also be perfectly logical and rational. [...] The decisive point is not what is thought but how it is thought." 123 Fromm associates "automaton conformity" with the "pseudo self." The condition is thus explained by the loss of identity. The abrupt collapse of ideas about life and desired bonds, coupled with the invasion of violence as a determinant of individual lives, could without a doubt undercut people's sense of identity. "[I]n order to overcome the panic resulting from [...] loss of identity, [the individual] is compelled to conform, to seek his identity by continuous approval and recognition by others. Since he does not know who he is, at least the others will know - if he acts according to their expectations; if they know, he will know, too, if he only takes their word for it." 124 Undoubtedly, the mechanism of the "collectivisation" of people and replacing "selves" with "pseudo-selves" was grounded in national and religious symbols and in the authority of their official proprietors. Consequently, the "pseudo self" of Poles was intrinsically national and Catholic.

\section{Variant Two: A Drama of Mortality and Eschatology}

This variant seems to be linked to authoritarianism. Fromm is known to have regarded authoritarianism as a sadomasochistic symbiosis that seeks to "overcome the unbearable state of powerlessness." 125 "Masochism is one way toward this goal. The different forms that the masochistic strivings assume have one aim: to get rid of the individual self, to lose oneself; in other words, to get rid of the burden of freedom," 126 as Fromm puts it. In turn, "[a]ll the different forms of sadism which we can observe go back to one essential impulse, namely, to have complete mastery over another person, to make him a helpless object of our will, to become the absolute ruler over him, to become his God, to do with him as one pleases." ${ }^{127}$ Fromm continues:

123 Ibid., pp. 192-3.

124 Ibid., p. 203.

125 Ibid., p. 139.

126 Ibid., p. 151.

127 Ibid., pp. 155-6. 
To rule over another person, if one can claim that to rule him is for the person's own sake, frequently appears as an expression of love. [...] Is not sadism, as we have described it here identical with the craving for power? The answer to this question is that although the more destructive forms of sadism [...] are not identical with the wish for power, the latter is the most significant expression of sadism. ${ }^{128}$

Fromm catalogues several notable features of the authoritarian character, which helpfully illuminate our argument:

The authoritarian character is never 'revolutionary'; I should like to call him a 'rebel.' $[\ldots]$ The authoritarian character worships the past. [...] The courage of the authoritarian character is essentially a courage to suffer what fate or its personal representative or 'leader' may have destined for him. To suffer without complaining is his highest virtue [...] Not to change fate, but to submit to it, is the heroism of the authoritarian character. $[\ldots]$ The concept of original sin [...] is characteristic of the authoritarian experience. [...] Man's own doing becomes the power that rules over him and never lets him free. The consequences of guilt can be softened by atonement, but atonement can never do away with the guilt.

Finally, Fromm concludes: "For the authoritarian character activity is rooted in a basic feeling of powerlessness which it tends to overcome. [...] The authoritarian character wins his strength to act through his leaning on superior power." ${ }^{129}$

In the specific Polish version of authoritarianism in the 1980s, "this world of mortality," in which one has to submit to "them" - i.e. to the state - because "force rules the world," represents the masochistic component, while the religious identification with the Church and the nation stands for the sadistic component. Incessant complaints about and grievances against "them," who force one to live the way one lives, fully justify relinquishing responsibility for the public good in everyday life. At the same time, the identification with national religion motivates the moral denunciation of "them" and all strangers as inferior, threatening and morally "flawed." This attitude is interwoven with permanent fear and guilt feelings, so characteristic of Polish daily life and religiosity.

\section{Variant Three: Egotist Escapism}

The variant of egotist escapism is implicated in the mechanisms of "escape from freedom" which Fromm describes as: "the withdrawal from the world so completely that it loses its threat (the picture we find in some psychotic states), and the inflation of oneself psychologically to such an extent that the world 
becomes small in comparison." ${ }^{130}$ Fromm does not discuss these mechanisms in much detail, because he does not attribute a lot of cultural relevance to them. However, in the Poland of the 1980s such mechanisms became very significant and common. In fact, researchers of Western societies have also taken more notice of them recently as contributing to the rise of the narcissistic personality.

Ortega y Gasset seems to have had a similar character in mind when he deplored the "superlative abnormality" of "the mass man" represented by the "self-satisfied man." In today's Poland, a specific species of the self-satisfied man has emerged which absolutises private needs and justifies them as purportedly springing from a universal ethical principle. As the principle is not honoured by "the system," we allegedly deserve to do whatever we can do to humour our whims. ${ }^{131}$

\section{Variant Four: Desperate Dissent}

This variant triggers destructive attitudes. "I can escape the feeling of my own powerlessness in comparison with the world outside of myself by destroying it. [...] If for any reason other persons cannot become the object of an individual's destructiveness, his own self easily becomes the object." 132 Fromm observes that: "There are destructive tendencies which result from a specific situation; as reaction to attacks on one's own or others' life and integrity, or on ideas which one is identified with." ${ }^{133}$ While this kind of destructiveness can be a rational response to threat, the destructive mechanism is at work when the individual permanently harbours hostility, only waiting for an excuse to display it. "It would seem," explains Fromm,

that the amount of destructiveness to be found in individuals is proportionate to the amount to which expansiveness of life is curtailed. [...] The more the drive toward life is thwarted, the stronger is the drive toward destruction; the more life is realized, the less is the strength of destructiveness. Destructiveness is the outcome of unlived life. Those individual and social conditions which make for suppression of life produce the passion for destruction that forms, so to speak, the reservoir from which the particular hostile tendencies - either against others or against oneself - are nourished. ${ }^{134}$

130 Ibid., p. 183.

131 Cf. Jose Ortega y Gasset, The Revolt of the Masses, trans. anonymous, $25^{\text {th }}$ anniversary edition (New York: W.W. Norton and Co., 1957), pp. $102 \mathrm{ff}$.

132 Fromm, Escape, pp. 177-9.

133 Ibid., p. 179.

134 Ibid., p. 182. 


\section{"Internalisation of Violence" and Privatisation of the World}

Quoted above, Fromm's words invite us to reflect on another issue. Martial law created the "individual and social conditions which make for suppression of life." The process of constructing a negative definition of the situation was society's response to violence which put an end to spontaneous social action and consequently thwarted innumerable individual actions.

The negative definition of the situation helped alleviate the disagreeable experiences to a degree and shove responsibility onto the world outside. The negative definition of the situation can thus be viewed as a paradoxical strategy of overcoming the experienced negativity of people's situation in life.

Popular consciousness began to avail itself of various means to surmount this negativity. One of them was a relatively simple operation referred to as repression in the Freudian framework. Namely, Solidarity seemed to be forgotten. Not only Solidarity's ideals but also people's engagement in social action were erased from popular consciousness. Particularly striking was people's decision not to hand the Solidarity experience down to the young generation, to their own children. The memory of Solidarity's legal activities seemed to be distressing as a memory of defeat and a reminder of how difficult it was to abide by the ideals treasured at the time.

Consequently, in another turn of events, people started to deprecate their own experience and ideals. Solidarity was re-positioned as "them" as well.

A feasible way of separating the individual self from the collective self of Solidarity was persistently offered by the official propaganda, which disseminated the cliché of Solidarity as an organisation vying for power. This prompted the belief that Solidarity would exercise power in exactly the same way as the communist regime did. The official propaganda proved successful, at least temporarily, since such an interpretation, as already indicated, was incorporated into the "fluctuating" definition of the situation. As the hatred of the humiliating winners abated, people's own experience and ideals were deprecated.

Crucially, the spirit of citizenship fell into oblivion in popular consciousness. The civil thinking viewed personal prosperity as dependent on the political system's capacity to foster effective collaboration and presupposed individuals' active influence on people's general prosperity. As a community member, one had the right to pursue one's own happiness, but one also thought of personal wellbeing as tied to others' success and, consequently, was ready to work for the sake of "common good."

The privatisation of the social world also bred an eagerness to fight for one's prosperity as the world was steeped in an egoistic struggle for personal interests, 
in which "the stronger" inevitably won. Power and interests came to be conceived in increasingly naturalistic, nearly biological terms.

This confirmed and additionally justified the negative definition of politics as evil and immoral. Governance meant one-upmanship. As such, it was immoral because, sooner or later, the human being was bound to defile him/ herself with violence in the name of self-interest. Governance and power were mendacious since, once involved in them, one trumpeted ideals, while egoistically committing only to one's own success. Such an image of politics (which, notably, was often found in totalitarian movements, including the communist movement) prompted subordination to the strong ones, but also salvaged one's self-dignity on condition that one kept one's hands clean. Taking action for the sake of material success did not soil one's hands.

Mentioned above, the family-focused ideology greatly promoted such thinking. Not only the "clean hands" but also the care for the family helped justify surrendering to violence and obedience to orders even if they completely defied common sense.

This attitude was fostered by what I refer to as the "internalisation of violence."

Such an attitude makes it nearly impossible to build a community. When one can count only on oneself, while the world is less the common good and more a trove from which one must "snatch" the needed and coveted goods, every other human being turns into a competitor. In this context, competition is not what the Western ideologues and sociologists have decried. Capitalist competition requires mutual negotiations and clear rules and, as such, is a form of social cooperation, paradoxical though it may sound. In Poland, the "natural competition" I am outlining is decultured and apparently governed by the principles of the biological survival of the fittest.

The attitude harbours a diluted hatred of the entire world, for the world of other people is always perceived as inimical, unpleasant, competitive and bent on robbing us of what we need and desire. Against this backdrop, strength, resolve and the effective use of violence can indeed be affirmed. Hatred is reversed, for the more powerful and the stronger one is, the more admiration one deserves.

Internalised violence is necessarily accompanied by the instrumentalisation of people and social bonds. In daily life, the internalisation of violence produces a new style of interpersonal relationships. Any situation of social contact (including situations of play) can only be effectively handled if the individual gains advantage over partners and can exert direct pressure on them.

Sociologists have repeatedly insisted that social relationships cannot do without the subordination-vs.-superordination interplay (which was compellingly 
described by Georg Simmel ${ }^{135}$ ). The subordination-superordination pattern forming spontaneously in Poland above all concerns commandeering others and imposing one's fashion of defining the situation. Specifically, the stronger can command in the symbolic sphere. What this implies is that as violence was internalised, the system of spontaneous human interactions in Poland started to reproduce the centralist model of social organisation. In his book Polish Society under German Occupation, Jan T. Gross insightfully analyses the General Governorate and the Third Reich to portray the social system based on the strictly centralist, peremptory principle. All social systems based on this principle are equally ineffective, as they continually engender anarchist leanings. ${ }^{136}$ Collaboration is permanently vulnerable to disruptions and erratic actions of various actors, despite their formal submission to their superiors' commands. The definition of the situation imposed by the commander induces both a docile acquiescence to orders as well as a revolt against and aversion to the commander.

This relationship model was widespread in "real socialism" period of the People's Republic of Poland; now its essential features have come to be spontaneously reproduced.

\section{The "Enactment" of Declared Values}

Yet, in spite of all the subordination mechanisms, in spire even of the affirmation of the party-state's power, the authoritarian affirmation of the victorious force and the abandonment of civil ideals, mainstream popular consciousness sought a positive solution to the situation. That meant an active disagreement with the status quo.

If practical life grew ever more dependent on internalised violence, a more or less formalised sphere of the symbolic enactment and collective experience of the declared moral and cultural values was forming at the centre of everyday life. The development was not identical with "ceremonial values" (wartości odświętne) as defined by Stanisław Ossowski. ${ }^{137}$ Rather, at its core lay the "enactment" of professed everyday values as ceremonial or solemn values. Crucially, a range of social activities were marshalled with the sole aim of collectively enacting and experiencing the values proclaimed to guide everyday life. They were elevated

135 Cf. Georg Simmel, The Sociology of Georg Simmel, trans. and ed. Kurt H. Wolff (Glencoe, IL: Free Press, 1950), Part Three.

136 Cf. Gross, Society, cf. particularly pp. 145-159, 199-212.

137 Cf. Stanisław Ossowski, “Z zagadnień psychologii społecznej”, in Dzieła, vol. 3 (Warszawa: PWN, 1967), pp. 88-93. 
into ceremonial values, but they were not intended to be practised in everyday life outside the symbolic reality in the belief that this was impossible. People behaved, so to speak, as stage-actors who, leaving the theatre, do not as a rule intend to behave like the characters they have just played on stage.

In Poland, the symbolic sphere of life grew uniquely autonomous to serve as an isolated, dedicated social stage on which to enact and document people's attachment to national and religious values, augmented with enigmatic sentiments of dissent and entitled veterancy: a symbolic participation in Solidarity's social movement.

Emphatically, despite the highly histrionic nature of symbolic reality, participation in it was anything if not a real experience, even though it was thoroughly impractical, if "practicality" is taken to mean the resolve to behave in accordance with the enacted and declared ethics. What happened in Poland was a species of the social "theatre of values."

\section{The Right to "Make Money"}

The opposite of the national and religious theatre, another way of finding positives in the negative world involves an ensemble of actions and attitudes which Marody has dubbed the "monetisation of consciousness."

Jan T. Gross observed analogous processes at work in the General Governorate. In his book, Gross writes:

Despotic rule of terror and equality go well together, as Tocqueville predicted. Nonparticipation in power, severing of individuals' links with their traditional reference groups (be it family, social class, or professional group) through physical displacement, discontinuities in authority patterns, impoverishment, imposed changes of occupation, dissolution of the state, political parties, unions and voluntary organizations of all sorts - all contributed to the atomization of Polish society. [...] Everything in the new situation was casting the individual away from his fellow citizens whom he no longer trusted, whom he feared, and with whom he fiercely competed in order to survive, gradually losing a sense of what are, or should be, the "rules of the game" of coexistence in society. ${ }^{138}$

Gross continues: "The only dimension of social stratification still effective in wartime society, the economic dimension, also demonstrated peculiar features in the Generalgouvernement." 139 Specifically, "The emphasis on money was evident in various aspects of Polish social life. In conditions of scarcity and inflation

138 Gross, Society, p. 177.

139 Ibid., p. 176. 
the major preoccupation of people is to find ways to earn more money." Gross insists:

It is important to note here that the confinement of all social interaction to economic exchange signifies a dramatic weakening of commitment to values as the regulative factors of social interaction and the disappearance of qualitative distinctions from social life. [...] The possibility of putting a price on everything, from a piece of bread to a human life destroys moral life as we know it. ${ }^{140}$

Gross describes a process in which money becomes the only gauge of the individual's social worth. I believe that this is exactly what we are witnessing in Poland today.

If it is so, the aim of the chase for money (registered so strongly in the popular consciousness of Poles) would be to maintain certain living standards and at the same time to produce mechanisms which, in the wake of social disintegration, could order the entire structure of social relationships by the money criterion.

Yet, in the light of the definition of the situation outlined above, what Marody calls the "monetisation of consciousness" can be viewed as one of the major strategies people in Poland use to find positive ways out of the predicament faced by the community.

Currently, "making money" is already erected into an institution in Poland. It is geared to accumulating considerable wealth (preferably in the form of a US dollar account) relatively quickly. It would not be adequate to classify the activities involved as the black market or the "black economy" because, basically, the processes are symbiotic with and condoned by the state.

People's commitment to "making money" either by starting their own businesses or by doing gigs abroad and by "foreign trade" at open-air markets has been boosted by legal and systemic policies encouraging spontaneous individual or group activities. The freedom and opportunities of social action in the economy have been remarkably expanded over recent years. Consequently, "money-making" has a political facet as well.

The free economic activity gravitates towards the market economy, i.e. towards "capitalism," to negate and abolish which once far all was socialism's apparent mission.

The activities praised now by the official propaganda were an object of heinous propagandist attacks but a few years ago, when a vast campaign against "profiteers" was launched in the semblance of the famed anti-capitalist campaign of the 1940s. In 1984-1985, patent references to history were by no means 
random: they deliberately aimed to mobilise public opinion in support of the government's operations and to sway "society" in favour of the "party-state."

Relative liberty granted to economic pursuits produced new opportunities of "playing with the system." No longer anathematised, money-making was allowed by the "system," so fears could subside. At the same time, the persisting obstacles and ideological relics of the past still helped people regard and fashion themselves as struggling with "them." Economic success could be framed as a victory in the fight against "them."

A peculiar and rather enigmatic contract was evolving between "the regime" and "society." The administration of the party-state okayed the spontaneously developing economic and quasi-economic activities. The price to be paid involved, importantly, not so much relinquishing political partisanship (as that had long been the province of a social minority only) as rather abandoning the widely manifested dissent attitudes. (One had to forego all gestures defined as political by the party-state and performed by people long after the lifting of martial law.) The state administration apparatus played quite a game with society, attempting to compel conformist behaviours and the endorsement of justifications for such conformist behaviours.

For all its specific aims and rules, the economy became a substitute of social activity for some groups and communities. Relieving frustration and the aversion of the "system," the economic activity did not remove political and social aspirations, providing at the same satisfaction and sustenance. For such individuals, groups and communities, small entrepreneurship helped re-capture subjectivity, influence upon their lives and the right of full communal participation.

Nevertheless, this truly positive impact of the economic space for manoeuvres within the strictly controlled site of social action only concerned a small social minority, predominantly groups associated with the oppositional social elite.

Things were rather different for the majority of the population. "They" had to make concessions pressed by society's real needs and the "natural" laws of life and economy - this is the gist of positivity achieved by popular consciousness. Options of entrepreneurship restored to people good moods and the sense of having control over their lives. Above all, they meant leaving behind withdrawal, shaking off passivity and encouraging initiative in the face of long-term prospects.

At the same time, fear subsided. By revoking the "anti-profiteering" campaign and enabling "money-making," the party-state authorities alleviated the previously ubiquitous dread and, at the same time, garnered an approval of people, who no longer needed to fear them. A common ground for people and "the 
regime" emerged, as both found money important and the pursuit of wealth understandable.

This leads us to an essential question: What was actually the relevance of the positive upturn of the negative definition of the situation?

\section{The Latent Negative Worldview behind Positive Changes}

"Negative" has meant different things in our argument. Fundamentally, the negativity of the generalised definition of the situation in 1984-1987 was about denying the aspirations, goals and ideals which had found their supreme expression in the social reformist movement of the NSZZ "Solidarity."

Even though towards the end of 1988, a possible re-construction of independent trade unions clearly emerged as a topic of interest, the prospect animated a less-than-considerable part of society. Popular consciousness was permeated with images of the world which did not nurture engagement in such activity and did not promote turning it into a personal aspiration which it had been back in 1980. "The positive" in popular consciousness was grounded in the right to "make money" and barely affected the substance of the negative definition of the situation.

I believe that, crucially, the underlying basic pattern of "people don't matter one bit" remained intact even if it was subject to a positive modification. "People didn't matter one bit" if they were not shrewd enough to either muster power to enforce others' obedience or to have money to buy others. Such thinking was interlocked with the philosophy of "natural egoism" and "primary needs", in which informed the negative definition of the situation.

What altered was people's attitude to the world, which was portrayed as a hostile space ruled by violence and mechanical force, where the only principle to abide by was the care of the self and, at most, of one's family.

Now, as this world image has been favourably re-appraised, people aspire to gain - if not power, which is after all "their" domain, and nobody yet wants to associate with "them" - money, which has become a partial equivalent of power in that it helps order and "commandeer" in everyday life situations. The secondary positivity achieved now by a considerable part of society is, as a matter of fact, rooted in the symbiosis of "power" and "money." Economic operations are not necessarily creative, and they do not really bode well for the future. Most of them, I believe, do not produce any new economic assets. Even when they provide goods, they do not expand the economic infrastructure. They do not offer new approaches to organisation, economy and production; nor are they based on technical innovation. Just the other way round. Success is facilitated 
by corruption and speculation. Rather than on any new economic principles, the economic freedom is based on the fact that legal norms and regulations are missing. As the "anti-profiteering" legislation can be re-instated at any moment, entrepreneurs have to be on good terms with the members of the partystate apparatus and possibly quickly accumulate capital in the forms which are least vulnerable to inflation (this is one reason why the art market has rapidly developed). Long-term investment policies are hardly possible in the current conditions.

Incorporated into the negative definition of the situation, the philosophy of "natural egoism" reduces the relationship between "my" prosperity and the community's prosperity to the point of non-existence.

The question is whether Polish society has just entered the stage of change with long-term consequences. In all likelihood, the positive re-casting of the generalised negative definition of the situation in the 1980s heralds a profound cultural transformation. Based on the consensus between the government and citizen, saying that making money is the most important thing, "positivity" is achieved at the cost of a drastic curtailment of aspirations and ambitions. There is more collateral damage to it as the traditional criteria of people's mutual evaluation are invalidated, and human personalities are depleted by excluding huge vistas of motivations and self-realisation modes. These changes first of all affect the hierarchies of values which were so emphatically and clearly championed at the onset of the 1980s. Now, precedence is given to what Max Scheler called utility values, ${ }^{141}$ which override vital values, values of life and moral values. As common principles are missing and law is not instrumentalised, it is no wonder that morality erodes, i.e. that moral norms and models are no longer capable of guiding people's everyday behaviours.

May - November, 1988

141 Cf. Max Scheler, Ressentiment, trans. Louis A. Coser (New York: Schocken Books, 1972), pp. 154-162. 


\section{Challenges to and Risks in Poland's Democratic Transition: A Social Psychology Perspective}

Below, I want to address Poland's democratic transition in rather specific terms. My concern is to assess social re-structuring in terms of human mentality, behavioural habits and normative patterns which are essential to our lives. Such assessment requires taking stock of social consciousness. By social consciousness I mean not so much the declared views reported, for example, in public opinion polls as rather less consciously grasped, latent mental structures that motivate people's everyday behaviours. Consequently, I will have to delve into the personalities and states of mind of Poles.

I will also have to identify personality features, states of mind, predispositions and action skills that are characteristic of modern democracies. By necessity, my account of relationships between people's attitudes and behaviours on the one hand and operations of societal institutions on the other will be considerably simplified.

\section{A Lyrical Model of Capitalism}

Let us start from defining what gives modern democratic systems, all their defects notwithstanding, an indisputable, positive advantage over other forms of social order. As I am interested in what it actually is that we so greatly admire about democracy and its typical economy, I paraphrase the coinage Jan Strzelecki invented to depict real socialism and will accordingly talk of a "lyrical model of capitalism."

At first glance, what we admire are common prosperity and a considerable sense of self-fulfilment and life satisfaction across the populations. The two aspects are interrelated. The contentment is often a target of criticism from, for example, churches, including the Catholic Church, which accuses people in the West of reducing ideals to self-realisation and satisfaction derived from earthly and temporary material achievements. This critique aside, all observers who study modern democracies from within other systems notice that their conspicuous moral feature is a genuine respect for the individual and the dignity of individual life.

This moral attitude is largely associated with prosperity, daily wellbeing and common life satisfaction, if not utter joie de vivre. The market economy, which is 
a developed, complex system of social actions, seems not only to promote good life, but also to bolster ethical values which Christianity gave Europe long ago.

Having experienced real socialism, what do we admire in the democratic market economy? I believe that we admire primarily its efficiency in achieving three feats: first, the effective attainment of prosperity and the improvement of living standards of mass societies; second, flexible innovativeness which helps societies, groups and individuals handle even serious livelihood problems, therein those occasioned by their own development; and third, the skilful employment of individual talents, desires and capabilities for the common good and utility as well as for individuals' satisfaction. As people who lived through real socialism, we cannot but be struck by the efficacy with which a socio-economic system can, so to speak, use individual and group aspirations, ambitions, talents and skills for the sake of both society and individuals, without breaching the fundamental principles of freedom and human dignity.

The market economy promotes dissemination of knowledge, education and development of cognitive and artistic capacities. It can also further cultural expansion and the accessibility of culture goods, albeit not necessarily of the highest quality. Mass culture is subject to a well-founded criticism as some of its facets are nothing short of disgusting. Nevertheless, in an overall view, it "produces" people who are open-minded rather than narrow-minded - people who are kind to others, sensitive to and respectful of individual, national and cultural differences and appreciative both of culture and of nature; in brief, people who cherish life in its many various manifestations. Mass-culture people, boring, superficial and boasting "plastic" personalities though they may be, are on the whole quite nice people.

The market economy has also transformed culture by channelling away people's aggression, domination drive and proclivity for hate. A lot of human expansive energy, which so tragically turned into criminal aggression against fellow human beings in the $20^{\text {th }}$ century, is now vented in the expansion of the material world and in peaceable economic expansion.

I mention this because the seeds of particularly disastrous developments in the first half of the $20^{\text {th }}$ century can be found in the principles of economic organisation. Yet, what I refer to here are the forms currently developed by democratic societies, which grow increasingly concerned with, for example, the future of the environment. The market economy has been shaped so as to make competition and rivalry conducive to social prosperity and individual success. The idea that competition can be viewed as a form of social cooperation has long been advocated in American social psychology, yet it was only in the aftermath of the Second World War that the theory produced related practice. In all likelihood, 
it was linked to the rejection of the notion that individuals, parties and nations were entitled to impose their will on others and, in this way, arbitrarily shape history. At the same time, egoism was restrained and insatiable individual appetites were reined in by socially accepted mechanisms, which helped view private interests in conjunction with the public good.

At this point, we can usefully turn to Tocqueville, who at the dawn of capitalism insisted that: "Several causes may combine to make the customs of a people less crude; but the most powerful of these seems to me to be the equality of social conditions which, along with the softening of manners are not only, in my view, coincidental but also connected." ${ }^{142}$ Tocqueville explains further:

When all the members of a community are almost equal and all men have almost the same way of thinking and feeling, each one of them can judge in a flash the feelings of all the others; all he needs to do is to cast a quick glance at himself. There is not, therefore, any distress that he cannot understand without difficulty and a secret instinct reveals to him its extent. Whether it be strangers or enemies will not matter to him as his imagination immediately puts him in their place, mingling something personal with this pity and making him suffer himself when the body of his fellow man is being torn apart. In democratic ages, men scarcely ever sacrifice themselves for each other but they display a general compassion for all the members of the human race. One never sees them inflicting pointless cruelty and when they are able to relieve another's suffering without much trouble to themselves, they are glad to do so. They are not entirely altruistic but they are gentle. ${ }^{143}$

\section{The Democratic Personality}

In democracy, the human being is an independent actor in social life. Individuals have rights which not only regulate operations of institutions, but also underpin the citizens' mutual relationships. Some of these rights are socially instituted, whereby everybody can participate in the process. The individual is involved in ongoing bargaining, negotiations and discourse, political, social and also economic. Pursuing one's own interest requires a clear and accurate recognition of one's desires, ambitions and, above all, possibilities. At the same time, it is imperative to understand others, their expectations, needs and desires to which we can respond with our "offer." We must look for partners and cooperate with others who think similarly, have similar interests and/or face similar problems. Such cooperation requires precisely defined rules and a clearly delimited scope of mutual

142 Alexis de Tocqueville, Democracy in America and Two Essays on America, trans. Gerald Bevan (London et al.: Penguin Books, 2003), p. 649.

143 Ibid., p. 653. 
relationships and, let us say, "dealings." Consequently, individuals must be active, adept in presenting themselves, their opinions and interests and ready to learn to accept that others are different. In the long run, the least profitable thing one can possibly do, whether in the economy or in politics, is to violate the agreed-on rules and to fail to meet the incurred obligations. Individuals thus develop perseverance, self-reliance and trust in their capacities as well as learn to analyse their experiences and control momentary moods and emotions for the sake of long-term goals and relationships with others. They think of their lives in terms of investments to be made in order to accomplish goals, ambitions and desires. Without ever losing sight of their own interests, individuals must embrace whatever they assess as furthering their development, facilitating collaboration with others and promoting goal achievement in compliance with the dictates of their consciences.

This has generated a personality model which is characterised by sound judgment, rationality, open-mindedness, cognitive and emotional vigour, reflectivity, activeness, self-awareness, resolve in strengthening the self, self-reliance, affection, eagerness to both collaborate and monitor collaboration in terms of its benefits, readiness to extend and accept help, and mindfulness of unignorable costs thereof. In a word, it is a flexible personality. Social changeability, best expressed in upward mobility, must go hand in hand with mental and personal suppleness.

This issue has been widely explored, as a matter of fact. Suffice it to mention David Riesman's already classic studies of the other-directed, radar personality and the latest concepts of humanist psychology.

What matters to our further argument is also the attitude to knowledge, education and work in democracies. Individuals only have to show for themselves what they have achieved on their own. Consequently, work is not only a source of income but also, crucially, a test of the person's quality. Contrasting work in democracies with work in the aristocratic system, Tocqueville observed:

As soon as work seems to all citizens an honorable necessity for the human race and is always clearly performed, at least in part, for payment, then the wide gap which used to separate the different professions in aristocratic societies disappears. [...] American servants to not believe they are degraded for working since everybody around them is working. They do not feel humiliated by the idea of receiving a wage, for the President of the United States also works for a salary. He is paid for giving orders as much as they are for obeying them. In the United States, professions are more or less laborious, more or less lucrative but never higher or lower. All honest occupations are honorable. ${ }^{144}$

This is, of course, a morally-laden ideal which has gone through various permutations both in the US and in Europe. The social sciences have either

144 Ibid., p. 640. 
offered theoretical justifications of or even themselves promoted systemic solutions that have sustained various iterations of this simple rule elucidated by Tocqueville.

In such societies, practical considerations prevail over high-flown ideals. However, the development of scholarship, particularly in the US, shows that Tocqueville's old observation that only practical sciences stood the chance in America has in fact given way to, if not smoothed the path of, a more disinterested and long-term development of all knowledge, especially theoretical knowledge. Although several insightful critics of contemporary democratic culture have denounced the disastrous effects of technical progress (to mention but Ortega y Gasset's classic works), it would be a challenge indeed to disregard the immense positive role of technical and scientific advancement.

Last but not least, the management style is also a relevant issue. Various developments in management and work organisation have increased employees' sense of participating in a common enterprise. Workplace interdependencies and the effects of the division of labour have been simplified, discussion and negotiation have been made part of the triangular relationship among employees, managements and owners, and various human needs, therein emotional needs, have been accommodated within the organisation of work.

In the democratic system, people do not fancy submitting to authorities. This is as much a source of great strength as a serious risks, which Tocqueville anticipated with remarkable insight and precision. At any rate, in democratic societies, the individual is, as a rule, not entirely dependent on another individual; nor is s/he at the mercy of other people's whims and ill-will. This also means that human relationships are dispersed, in the sense that people depend on each other within defined and understandable limits, coming in touch with each other via various social roles. It is relatively easy to put up even with a very unpleasant hardship if the effort is predictably limited in time and rewarded by gains elsewhere. Naturally, this situation involves a certain cost, including above all a gnawing solitude and an acute lack of direct, spontaneous intimacy with another person, a reliable companion for better and worse.

Admittedly one-sided though the above account is, it does represent the overall positives of human personality in the democratic order.

\section{Polish Negativity}

Briefly put, Poles' mental attitudes and mutual relationships sharply contrast with the portrayal above. I do not believe that the circumstances and conditions currently (i.e. as of 1990) observable in Poland promote positive personality 
patterns. People are not infrequently sorely disappointed with what they have become under the pressure of the circumstances and the adaptive mechanisms they necessitate.

Elsewhere, I described the mental state of Poles as "negativity." Another term to be used in this context would be "a negative definition of the situation." What I mean by this is a generalised attitude to, and even an image of, the world and one's own life. The attitude/image is informed by the belief that "nothing good can be expected of life," that is, at least of life in this world, especially in Poland. Life prospects are vague and uncertain; life space is ridden with hostility, aversion and unkindness. The inimical public space is contrasted with the private realm of family life, yet even there unalloyed satisfaction is not to be expected, while homes and flats are threatened by thieves and crooks. This belief paints the entire world and people's own actions in dark colours. Consequently, whether or not any real obstacles are indeed in place, every activity - even, if not particularly, the economic activity - requires exhausting mobilisation and begins as a war party against the hostile world.

Mobilisation is indispensable. It takes loads of energy to overcome uncertainty, the fear of independent action and awaited obstacles, a distrust in one's capacities and suspicions about the intentions of people who offer to cooperate. To start any action, the individual must brace up for both offence and defence. When offence predominates, action begins as an assault or an invasion. When defence gets the upper hand, the individual moves stealthily, like a thief, to snatch the targeted goods when an occasion offers itself.

\section{Social Action as Warfare}

Collaborators and possible partners in action - e.g. parties to a contract - can only be treated either as our bitter enemies or as our closest allies. It is vital that collaborators be utterly united and one-minded, which is best achieved by ultimate group control. Because all collaborators are equally distrustful and suspicious, deciding who "is in charge of the whole thing" is the precondition of joint action. Only a strong leader can make people cooperate effectively. At the same time, however, a strong leader is a challenge to all the others, for people can only feel relatively secure when being in complete control of the situation. Consequently, one had better seize the superior position and make others subordinate. When one finds oneself in a subordinated position, one submits fully to the leader and shuffles off responsibility for the outcomes of the action on him/ her. At the same time, one only waits of the leader's misstep in order to seize advantage. 
This is not a purely theoretical description, regrettably. In 1987, sociology students conducted, as part of coursework, an informal study which found such attitudes in a completely voluntary and highly untypical group. The sample was an association of parents of children with cystic fibrosis. The Association was founded by the parents to support each other in helping their children survive. However, the students observed that the voluntarily associated parents were unable to collaborate effectively. They approached their mutual obligations as formal, institutional roles. They were afraid to take any initiative on their own accord and only did what they were formally obligated to do. For example, the Association's president refused to drive to another town to fetch bananas for which the parents had been waiting for several weeks, saying that another parent was supposed to arrange the transport and the president was president and not a driver after all...

If action is conceived and implemented as warfare, all social apparatuses, including law, must be treated as strategic elements instrumental in achieving one's goals. Law is contrasted with life and its needs. People's energy is used to by-pass law, take advantage of legal loopholes or ignore law altogether rather than to advocate for new law and reasonable regulations promoting useful activity. At play here are also the individuals' negative self-images, because people do not perceive themselves as capable of lawful action or of influencing the legislation. A similar attitude is also dominant among societal institutions, including the state.

\section{Bad Individualism and Bad Identity}

This is exactly opposite to what one wishes for in a democratic society. The example above shows that even a parental self-help association is treated as something that is "not ours."

Polish society is permeated with bad individualism, i.e. individualism which does not promote long-term expansion and entrepreneurship correlated with broader social outcomes. This kind of individualism is hostile to others, selfish, envious and aggressive; its actions are restricted and short-term. Briefly, it is an individualism of cowed, unsuccessful shopkeepers, which has so often been analysed and ridiculed in scholarship and fiction.

This self-seeking individualism is more focused on defence than on expansion. The desire to do something and ambitions to make a fortune wrestle with a fear of independent action and a distrust in one's capacities. In Poland, one more piece that completes this mosaic is uncertain identity: "Who am I after all?" The negativity of Poles is marked by the disintegration of people's social identity. People 
usually assess themselves negatively and do not view their talents and abilities as possible springboards to the coveted material success. In popular consciousness, self-fulfilment, the realisation of dreams and the satisfaction of financial ambitions are dissociated from one another.

\section{The Manly Attitude}

The situation as sketched above is shaped, I believe, by a number of deep-running factors. Entrepreneurship requires, so to speak, a manly attitude. It requires an active and business-like approach not only to the world, but also to oneself: one must demand a lot of oneself, face up to difficulties and learn to overcome them. The manly spirit is a spirit of responsibility coupled with calculated risk-taking and vigorous exploration. The world is a compelling space of freedom, where ample risks are intertwined with ample rewards. As I define it, the manly spirit firmly believes that there is a permanent order of values and that the human being must discover it on his/her own both within and in co-existence with others. It is a human duty to strive after ever higher values, to engage in independent action and to achieve outcomes to be shared with others. Thereby, one must respect those from whom something can be learned and whose success can serve as a model to emulate. Respect is also due to one's opponents as only an honourable fight can give the winner any satisfaction. This entails appreciating the accomplishments of human spirit and labour. Such an attitude is worlds apart from the collective spirit and the defensive stance, though it can have its aggressive and offensive manifestations. Crucial to this approach is eagerness to compete with others in accordance with the negotiated criteria in order to see who is really superior. Given this, respect for values is an inalienable component of this attitude.

\section{Babstwo: A Short Theory}

The manly attitude as defined above is a rarity in Poland. In our everyday reality, an entirely different attitude seems to be on the ascendancy. I refer to it as babstwo ${ }^{145}$ yet it should not be taken to mean any antifeminist sentiments. As I see it, both true femininity and true masculinity are ousted when "babstwo" comes to prevail.

145 Babstwo does not lend itself to translation easily. The slightly archaic-sounding, pejoratively (and also condescendingly) coloured noun denotes the totality of features typical of a baba and, at the same time, the totality of baba's, with a baba generally meaning a woman who is either old or ugly, or irritating, or uncultivated, or any combination of those. (translator's note) 
What is "babstwo" essentially about? First of all, it is underpinned by the belief that "life as it is" is a fundamental value, with life meaning biological life, life as given to us as such, life in and by itself (to refer to Hannah Arendt). What is the use of higher values, moral accomplishments or improved living standards when life as such is gone? Consequently, it is our basic duty to protect life. Interestingly, though this is patently not what Christianity champions, such an attitude is now very easily enveloped in religious justifications. Is life not a gift of God Himself? Is it not our primary and humble duty to accept it as it is and collectedly bear all adversity and humiliation in submission to the stronger ones in order to save life itself whatever it may be like? Nineteenth-century ecclesiastical ideas and ways, which are having their revival in Poland, offer this position a wealth of persuasive justifications. On this model, Christianity's crucial tension between life and Life, between this world and eternity - the harrowing question how (and, at the same time, a task) to enter the Kingdom of God in spite of, nay, through the paltriness of everyday existence - is completely obliterated and moralistically belied. Life is the greatest gift in its "natural" version. What is left for the human being to do is to abide by equally "natural" morality, which aggrandizes dutiful religious observances, clings to a sexualitycentred code and exalts the care of family and kids as the pinnacle of individual moral effort.

"Babstwo" can thus thrive in Catholicism, ignoring the teaching of the cross, which challenges such a notion of life as the highest value. "Babstwo" is thus not restricted only to one sex though, admittedly, it is easily adopted as women's natural ideology, because it emphasises protective, maternal and matronly functions. The attitude is through and through conservative, though what it seeks to conserve is an already stale life. This variety of conservatism commands to defend the status quo rather than risk the loss of biological existence. It conforms to circumstances and is ready to preserve itself at any cost, braving all humiliation and all abomination just to survive.

Morality is placed at the service of "life as such," while any otherness - unnatural, different and impudently disagreeing with the "natural" voice of the herd is treated as the chief enemy. The principles of nature, i.e. norms and normalcies, are erected into true morality. And our good Lord is believed to bless the natural, the regular, the gregarious. God is, so to speak, neutralised.

"Babstwo" breeds an array of attitudes which are discrepant with the manly spirit, such as cunning, patient manipulativeness, obstinacy and non-objectivity. "Babstwo" lies in waiting to pounce at an opportunity when it offers itself, but avoids open confrontation; it engages in murky dealings; it seeks to make others emotionally dependent on itself; it merges with the flock and seeks naturalistic 
justifications of all things. Consequently, the sources of life, i.e. "neutralised," codified God and the mother, are lavished with utmost significance.

This model is used in Poland to justify the practical power of women, especially those who frame themselves as the Matka Polka - the Polish Mother. ${ }^{146}$ The "babstwo" model is without a doubt reinforced by Catholicism and works against the manly spirit of freedom, independence, self-reliance, rivalry coupled with camaraderie, friendship and cooperation for the common good. The syndrome of "babstwo" exiles or, at best, undercuts disinterestedness. In order to continue, "life as such" has the right to subdue everything and everybody around.

Democratic polity and market economy are hardly imaginable without some element of disinterestedness. One must allow others - all "others" - to join competition. The social game, whether political or economic, is supposed to determine who is better and worse, whose propositions are more useful and whose solutions are more effective. In order to win, I need to calculate and if my calculation is correct, I will win. In "babstwo," calculation is, basically speaking, pre-arranged so that fair loss is precluded. I must win because "life as it is" is the greatest value.

\section{Resentment, or Poles Are Owed It}

Consequently, any loss is by definition felt as an injustice and, as such, induces jealousy, envy and resentment. Resentment, as described by Max Scheler, is apparently a major factor in the Polish mentality. It is also, nearly by necessity, associated with "babstwo." "Babstwo's" central premise is that all "normal" people who abide by the naturally and commonly endorsed moral code are equal. In Poland, it means that if a person is a member of the nation, observes the commandments and is "normal," the person deserves to succeed. If they do not succeed, it must be blamed on some "others," such as Jews, homosexuals, masons, plotting communists or any other "abnormal" individuals or groups.

Nationalistically coloured, Polish "babstwo" combines excessive protectiveness with xenophobia and deprecation of strangers, whatever their pursuits and whatever benefits could be gained from cooperating with them.

146 The Polish Mother (Matka Polka, literally: Mother Pole) is an often used and abused ideal of a selfless, self-sacrificing and much-suffering woman - a devoted mother, a fervent patriot and a zealous believer in one - derived from Polish Romantic literature and the messianic ideology which was developed in the period of partitions. (translator's note) 


\section{Authoritarianism and Lost Subjectivity}

Both "negativity" and "babstwo" - alone and combined - abolish citizenship as a source of human self-realisation and an embodiment of trust in the social world and life. Produced by either of these psychological complexes, individualism is rebellious and entitled on the one hand while self-insecure on the other. Because of this uncertainty, it seeks justifications in external rationales and in licences which can be provided by religious morality, the leader's moral supremacy and/ or the nation's authority.

At the same time, Poland has been fuelled and invigorated by a money drive for quite a while now. The desire to make money and grow rich has overridden other motivations and, consequently, undermined the characteristic value structure of modern industrial (or post-industrial) societies. In Poland, the general public consider money to be an equivalent of power, which gives mastery over others. The situation is indeed paradoxical as, on the one hand, moralism thwarts rational analysis and clear dealings among people while, on the other, principles and obligations have been evacuated from the practice of daily life. The social hierarchy is currently based on possibilities to subordinate other people. Money has emerged as another source of power besides violence, which, without subsiding, has been democratised, so to speak, in that it is no longer the exclusive prerogative of the Party apparatus.

\section{Money, Money, Money...}

In democratic societies, the market economy makes money a specific, practical gauge of value. Max Weber already concluded that the power of money was more democratic (and, thus, fairer) than the power of privileged groups or of the centralised state. Elevating money into the measure of worth in social life provoked censure from both Christian and socialist critic. As democracy developed, the citizenship ethos consolidated and the commitment to natural human rights grew, as called for by the critics of $19^{\text {th }}$-century liberal capitalism. In this process, democratic societies skilfully demarcated the scope of the power of money. Indeed, money serves as a good yardstick of the real value of goods, actions and human abilities across various spheres of social life.

In Poland, however, money still is not an accurate measure of real values. Of course, the raging inflation we experienced did not help. Neither does the fear of inflation now. But the economic phenomenon of inflation can be scrutinised from a wider cultural and sociological perspective. The economic inflation can be viewed as an outcome of disturbed social life. I believe that one of such disorders 
is, precisely, a chase for money as a source of personal power and advantage over others. Money-making has become a major avenue to human self-fulfilment, while money itself has been redefined, turning into a coveted good and a guarantee of security, instead of a means to an end.

Such an attitude to and the social role of money (i.e. as a source of power and security) unsettles what lies at the basis of democratic societies.

\section{Forgotten Labour and Devalued Education}

In August 1980, one of important popular concerns and grievances was that people felt that the management system squandered their efforts and labour. Popular consciousness construed the economic crisis as a ramification of disrespecting people and of wasting the effects of their work. In the wake of martial law, in turn, people started to boycott work. Enslaved and squandered labour, which brought neither satisfaction nor pay corresponding to people's needs and efforts, was ubiquitously spurned. The common belief was that the disastrous economic situation would force the communist regime to offer socio-political concessions, as had been the case before. However, there was a serious downside to this spontaneously adopted strategy, and it soon backfired. Working for "them" was viewed as a necessary evil, while competent occupational role performance smacked of a moral failing. It did not take long for people's identification with the workplace and, more importantly, with the work role to evaporate. As a result, labour was progressively devalued, losing its substantive and moral relevance.

The devaluation of labour was paralleled by the devaluation of education and knowledge. Knowledge neither helped understand the world nor offered quantifiable benefits. Education required considerable investments yet ceased to matter, as it did not bring any profit, while potentially causing additional frustration: an educated person was by default predestined to occupy higher positions in organisations, which entailed either getting embroiled in corrupted dealings with the party-state or, the other way round, manifesting dissent.

It takes a lot of effort and time to re-ignite aspirations for knowledge and education as major drives of social promotion. But, alongside restoring honest work, it is the main prerequisite for Poland's rise from its civilisational slump.

\section{Evil Legacy: An Evil Capitalist}

Another adverse element of Poland's cultural legacy is an entrenched, morally reprehensible image of an entrepreneur and a business owner. Despite an abrupt 
re-appraisal of the image of the capitalist, the negative stereotype of a business proprietor (disparagingly referred to as prywaciarz) still haunts collective consciousness and perhaps even subconsciousness, as Carl Jung would have put it. Starting a business of one's own involves overcoming a taboo, with all the various psychological consequences it occasions. Even if one manages to be efficient and to make honest profit, the entire enterprise seems "impure" and morally ambiguous by default. In the long run, such associations invite one to flout rules and obligations as one has anyhow already entered the forbidden zone. As a result, one tends to treat partners either offhandedly and unfairly or aloofly and also unfairly, whereas negotiations cannot possibly be successful unless one treats potential partners, whether weaker or stronger, as equals. Old habits die hard, and, while not dead yet, they severely impede such an approach.

\section{The Future and Liberalism: Anxieties and Concerns}

The socio-psychological condition outlined above poses many threats to the development of democracy and the market economy.

Particularly adverse, in my opinion, is people's scepticism about the future and about their capacity to actively shape their lives. For the last twenty years, sociological studies have invariably found that most Poles do not believe they will realise their plans and live the lives they desire. It is an important finding since the market economy cannot develop without prospects, without faith in the future and without the belief that efforts made today will bring copious fruit tomorrow. To thrive, the market economy requires, on the one hand, stable legal and political structures and, on the other, patience, strong will and accumulation of individual human effort. The long years of comparing capitalism and socialism (dubbed real socialism) prove that Marx's portrayal of the market economy was profoundly wrong. He disregarded the legal order of democratic governance as the basis of and the framework for the free-market game and its ostensible chaos. Exposing the harshness and hostility of the economic laws to the vulnerable ones, Marx ignored other laws which help regulate the market mechanism when it drastically breaches the principles of justice. At the same time, both our and Western experience suggests that the liberal ideology of the free market is as utopian as the communist and socialist visions. Liberal ideology makes assumptions about human nature, believing that uncontrolled individuals involved in competition for goods will sooner or later grasp the value of collaboration and develop an awareness of the common good, as a result of which everybody will find their proper place in the social world. 
Such assumptions are not entirely correct. The benefits of the market economy only materialised when democratic societies had built institutions to alleviate the injustices of capitalism and give the market players a sense of security. I highlight this aspect because Poland seems to be in the midst of a resurgence of the classic liberal thought, which only strengthens negative attitudes and does not contribute in the least to a real social reform.

Society emphatically backs the market-oriented reform of the economy, yet their support springs predominantly from an infatuation with the Western prosperity, which, as any infatuation, is blind in it obliviousness of the vast effort hidden behind the eye-catching facade. Most habits of Polish society directly contravene the principles that govern everyday life in Western democracies. Traditional liberal ideology often boosts bad individualism, which is afraid of and hostile to the world as well as reluctant to observe rules unless direct violence or direct profit ensues. The defensive focus prevails over dedication to development, and the egoistic impulse to accumulate goods for fear of the unknown future precludes long-term investments, which promote stable, albeit slow, growth.

I have my reservations about the impact of classic liberal ideology in Poland because, I believe, what Poles need most now are a sense of security and an assurance that there are opportunities for everyone and that efforts will pay back sooner or later. I do not mean a sense of security which nurtures inaction and produces stupor. To stimulate social, economic and political activity, which is a precondition of any reform, classic liberalism must be extended and complemented. People need to be sure that failure will not ruin their lives, will not reduce them to starvation or beggary and will not deprive them of further opportunities.

The fear of action and the fear of the future are very strongly correlated. Both kinds of fear arise when people believe that they have no influence on their lives and are mere pawns of destiny. Ominous external powers have not disappeared from the stage of history and even less from the stage of human world concepts. There is always something or someone - "they" of this or another kind - that can foil human plans and smash human hopes, as it happened on $13^{\text {th }}$ December $1981 .{ }^{147}$ That day saw the onset of society's exacerbating atomisation and of the progressing disintegration of bonds, relationships and solidarity. At the threshold of capitalist reforms, we face another threat, fearing that people will be left to fend for themselves if they fail. The Solidarity times should be evidence enough 
for us that the sense of community and unity in the shared fate animates people, reinforces individual initiatives, fosters a comprehensive enterprising spirit and bolsters courage.

In my view, economic reforms will not succeed if the broad public do not regain this sense of participation and the belief that the lives of common people do matter.

Another issue that deserves a serious thought is what strategies should be applied in converting the economy into the market model. So far, privatisation of the national assets has been contemplated. Given Polish society's current structure and its atomisation with all its mental consequences described above, I believe it would make sense to consider first of all a family-based business model as a viable direction in which the economy should be developed. The atomisation is so deep-running and omnipresent that it will be a serious challenge to encourage people to collaborate with each other.

Family-based economic organisations seem a feasible alternative which is likely to cause the least mental and social cost. Therefore, reform policies should implement this model, tending at the same time to ordering the state structures in preparation for privatisation.

November 1989 - Summer 1990 



\section{Part Three After Solidarity: Introduction to Part Three}

The third and last part of this book consists of writings published several years after the events and developments that made up the Solidarity social movement both in its legal and its "underground" periods. Though the specific concerns of the respective texts vary, they all more or less directly refer to Solidarity as the "originary" or "founding" moment of contemporary Poland.

The political transition commenced by and under the cabinet led by Tadeusz Mazowiecki, Poland's first non-communist Prime Minister since 1945, very quickly produced truly political and ever more widely differing actors of the democratic stage. In the wake of the presidential election in 1990 (the first fully democratic election in post-war Poland), both the civic political faction and the Trade Union "Solidarity" were riven by radical divisions. The split came to be enduringly symbolised by the remark about "the war at the top" (wojna na górze) made by Lech Wałęsa in the heat of his utterly relentless competition against PM Tadeusz Mazowiecki. The one-time close allies turned bitter enemies in a very aggressive campaign in which Wałęsa fought by crook or hook. Fortunately, Solidarity survived as a trade union and for a while played an important political role as a vehicle of the will of political transformation. However, ideological and political dividing lines were even then anything if not deep among tradeunionists. The trade union's leadership would soon start to make very obvious, if not glaring, political declarations, transforming into undisguised supporters of certain political parties. Consequently, it did not come as a surprise that Solidarity's membership continued to shrink, especially in the wake of subsequent elections, when Solidarity's political partisanship was at its most blatant. As a Solidarity researcher, I know that the current members of Solidarity commonly believe that the organisation's strong political engagement does it no favours. Yet even all those years back, Solidarity as legalised again in 1989 was an entirely different social actor than the original trade union of that name, which came into being in Gdansk in 1980. 
In the texts which I call a theory of the Solidarity social movement, I sought to highlight the movement's essential and most typifying aspects. I focused on what made the Solidarity movement "revolutionary" on the one hand, "reformist" on the other, and simultaneously peaceable, which somewhat confounds the traditional denotations of these terms. A peaceable revolution is, after all, a paradox. But this is precisely what the movement in fact was, paradoxical if anything. At the same time, the Solidarity movement was highly creative in developing and testing solutions which were to serve as building blocks of the new order of society and polity. At its heart lay democratic and civic ideals as social action restored dignity to people as citizens and made civic engagement in the social movement a relevant personal - moral and mental - value. Participation in social life gave individuals a sense of fully lived lives and personal fulfilment. Put in lofty terms, there was indeed something of the ancient direct democracy in that (emphatically) common feeling that every citizen was instrumental in shaping the shared fate of all... Civic engagement and the practical use of civil rights were experienced in Poland as ushering people into genuine maturity, where responsibility for oneself and one's family fused with co-responsibility for the country as a whole. People universally believed that personal happiness and wellbeing could be complete only if entire society enjoyed success. This was also how the idea of solidarity and community manifested itself in practice. Moreover, involvement in social action, in trade-unionist activities, bolstered personal intellectual and spiritual growth. One symptom of such development was a change in the language used by tradeunionists, even by those who did not have much formal education. ${ }^{148}$

The change of the Trade Union Solidarity mentioned above overlapped with a far more poignant change in social life and in Poles. The marvel of civic engagement, which engendered the Solidarity social movement and trade union, very quickly started to morph into an entirely different attitude. Various commentators, journalists and scholars have observed that, throughout the 1980s, reprisals, harassment, prison sentences and what practically boiled down to expelling people from the country did not fully enfeeble the citizenship attitude. ${ }^{149}$ However, when

148 Wojciech Ogrodnik, a researcher of Solidarity, has observed that most former tradeunionists, especially those from outside big cities, decided to re-engage in education after 1989 in order to complete high school or to enrol at university. When we conclude our project at the beginning of 2013, we will present a detailed account of this process.

149 This is powerfully documented in Inka Słodkowska's book Społeczeństwo obywatelskie na tle historycznego przełomu: Polska 1980-1989 (Warszawa: Instytut Studiów Politycznych PAN, 2006). 
the world of communist violence started to fall apart unexpectedly and rapidly, when overnight we found ourselves in a country with the freedom of expression and (social and individual) action, when a new state founded on the will and rights of all citizens started to take shape, something changed profoundly in Poles' attitude to participation and involvement in the emergent democratic politics. It was as if the experience gained in Solidarity activities had evaporated, "vanished into thin air." In very general terms, new models of "mature life," of satisfying life, appeared. Amidst national and social liberty, the once-thriving civil society wilted and withered. The less-than-solidary spirit of competition and individual success came to dictate the pursuits of Poles as the noble models of social and political action developed by Solidarity disappeared from the political practice of the new elite which had emerged from the vast social movement. The political and psychological hiatus of the "war at the top" determined the shape of a new political culture. The signature features of this culture are extraordinary aggression and relentless competition, which tend to make collaboration for the sake of the common good a sheer impossibility.

Another text in this part reports on a series of collaborative studies which were carried out by the Institute of Social Change Theory and the Centre for Research on Solidarity and Social Movements in 2010-2017. We called this project Solidarność. Doświadczenie i pamięć (Solidarity: Experience and Memory), which also served as the title of two books published in Polish. ${ }^{150}$ Written especially for this volume, the chapter discusses the findings of our investigation into how people remember their participation in the Solidarity movement.

The next text, which also refers to the series of studies on the memory of Solidarity conducted in 2010-2017, was written for the Gdansk Areopagus, an extraordinary project launched by Gdansk-based priests. In collaboration with a commercial (and thus independent) information channel, TVN24, the priests held debates with the public in attendance. The debates concerned various matters of import and urgency to Poland, Europe and the world. Regrettably, the new Bishop of Gdansk put this great initiative to an end. In the Polish Church, which supports - also politically - Poland's current, anti-democratic government, openness and independent thinking are marginalised by the traditionalist, hierarchical and nation-trumpeting mainstream. The text refers to the role that the Catholic Church once played in Poland as an advocate of individual dignity

150 Ireneusz Krzemiński et al., Solidarność. Doświadczenie i pamięć (Gdańsk: Europejskie Centrum Solidarności, 2010); and Ireneusz Krzemiński et al., Solidarność. Doświadczenie i pamięć po raz drugi (Gdańsk: ECS, 2016). 
and a supportive companion of the nation and people in struggles for a better social order - the Church that took the leadership function as a wise advisor rather than as the master and keeper of people's consciences. The text focuses on the factors which made the Solidarity reformist movement appreciated by and relevant to the world, i.e. on its non-violent commitment to the "peaceable revolution." I believe this is highly pertinent today as tensions increase across the world, not least in Europe, and Poland actively cultivates the model of politics as warfare. This war, symbolic though it is, effectively destroys the order of collective agreements, which the original and most important Solidarity sought to institute.

I called all these explorations by the umbrella term "After Solidarity," even though a trade union going by this name still exists. However, I believe that the practices of this trade union, in particular its political pursuits, have compromised its name. Essentially, this last part examines contemporary Poland, a Poland of what seemed a while ago consolidated democracy, which is nevertheless being demolished as I write of it. The demolition is progressing with the approval of the historically named trade union. While we are standing at the threshold of sad times, a recollection of true Solidarity can give us hope for the future. 


\section{Solidarity: The Organisation of Polish Hopes}

The title of this Chapter is not a random word-choice, of course. In the following, I would like to address at least two issues related to the Solidarity movement which are, as a rule, rather vague and underappreciated in sociological studies. At the same time, without exploring them we cannot either offer an adequate account of the Solidarity movement or grasp and spell out its implications for sociology and social experience.

The term "organisation" is not random, because I want to emphasise what I consider to be a sociologically seminal feature of the Solidarity social movement, that is, its remarkable organisation and institutionalisation of social actions. After all, actions and activities that make up a social movement are supposed to be essentially spontaneous, as probably all social researchers admit despite their different theoretical frameworks. The researcher and theoretician of social movements Alain Touraine wanted sociology and its intellectual method to furnish spontaneous actions with a more organised, focused and rational form. By the same token, he presupposed, like his colleagues, the spontaneity of social actions to be the primary property of social movements, a property opposite to orderliness, in particular to a technically conceived, bureaucratic ordering.

However, the Solidarity social movement from the very beginning developed and clustered around its own organised institution, i.e. the Independent SelfGoverning Trade Union. Since the NSZZ "Solidarity" was founded, neither its rank and file nor its activists and leaders across its hierarchy had had the slightest doubt that the trade union expressed and represented - in many different ways to boot - a far broader community, that is, the social movement. Interestingly, the members of the rapidly expanding and consolidating trade union first thought of themselves as a "social movement," even before sociologists labelled them so. This consciousness demanded re-reading the classic literature and re-vamping theoretical concepts.

But the term "organisation" refers not only to the establishment of unionist institutions, because the trade union itself organised people's hopes as well, and not only collective or common hopes shared by all, or at least by an overwhelming majority; it was also a unique form of organising individual hopes, dreams and even plans of millions of people. In 1981, Poles decided that they could dream, that is, that they could freely think of the future. The point to explore is in what sense and how the trade union came to serve as a frame of individual dreams and hopes. 


\section{The Transformation Process: Preparations for Joint Action}

To establish this, we need to re-trace the most important mental transformations (to use a verbal short-cut) which it took for such a mass social movement to develop in the first place. From the very beginning, it had been, after all, a movement of protest against and disobedience to the communist regime, to the partystate. Thus the social definition of the situation which was capable of spurring people to undertake independent, self-determined actions must have been very explicit and shared by a major part of society, at least by the organisers of the protests and later of positive action, i.e. the foundation and development of the trade-union movement.

The process leading to this point was rather nebulous at that time, but it should be relatively easy to re-trace it in retrospect. In the process, two elements of social self- awareness underwent a particularly thorough change. First, the election of Pope John Paul II was a momentous event in (among other things which I will address later) improving Poles' collective, national self-evaluation as well as people's individual self-evaluation, at least in terms of their social identities. This increase in self-esteem was a precondition of mustering the courage to launch joint action. The change of self-image and the growth of national pride involved an ensemble of values that promoted such action.

As the image of the real-socialist social system also changed, disappointment with and opposition to the order in place escalated rapidly. The last but not least important factor in the process was a rampaging socio-economic crisis coupled with people's ever more widespread knowledge about the exorbitant and still growing foreign debt incurred by the Gierek-governed state. Gierek's experiment of salvaging real socialism by advertising its consumer version - an affluent socialism matching the West - was patently and miserably failing. Additionally, the dramatic events of workers' protest in June 1976 belied the promises made at the onset of the Gierek era and brutally trampled working people's dignity, both literally and symbolically. The charisma Gierek had projected and enjoyed for a few years crumbled into dust. The exacerbating crisis and mounting social problems only strengthened the belief that the system did not respect common people.

The democratic opposition came into being in response to the contempt of the party-state for the protesting workers. Initially, only some of the intelligentsia were involved in oppositional activities, though increasingly more people and communities cooperated with the opposition. Nevertheless, that first significant gesture of solidarity of intellectuals, professors and journalists with the workers who had fallen victim to reprisals proved a powerful symbol of social 
community. Before workers had associated the intelligentsia with the regime, now the intelligentsia offered workers their help and solidarity. Still, the newly founded Workers' Defence Committee (Komitet Obrony Robotników; KOR) was at first treated rather distrustfully by workers. Despite that, the organisation had a huge (and growing) symbolic meaning and paved the way for an entirely new thinking about the situation and possible ways of changing it. Soon, other independent organisations were set up: first, the Movement for the Defence of Human and Civil Rights (Ruch Obrony Praw Człowieka i Obywatela; ROPCiO) and, then, the Confederation of Independent Poland (Konfederacja Polski Niepodległej).Yet, in hindsight, the gesture of solidarity with workers - who not only suffered harassment but were also relentlessly debased as working people, despite the insistence of the official propaganda that the working class played the leading role in the socialist state - was perhaps even more significant than practical effects of independent aid. Crucially, this gesture affected the ways of interpreting Poland's recent history by bridging the gap that yawned in popular consciousness between the intelligentsia's protests (students' demonstrations in in March '68) and the workers' protests (the December'70 events in Gdansk and Szczecin). On those occasions, the two social groups did not support each other. The foundation of the KOR symbolically overcame that meaningful and consequential social divide.

Besides its symbolic significance, the rise of the democratic opposition had also very practical consequences. First of all, the democratic opposition developed a language of moral and political dissent, and its strategic goal was to promote civil society under the nose of the quasi-totalitarian system. One of the kind, these strivings bred extremely good results in Poland. ${ }^{151}$ Thus, despite what looked like a very modest appeal, the major figures of the democratic opposition and the main freedom-focused slogans were conspicuous against the backdrop of the increasingly desperate success propaganda at the dusk of the Gierek era. Hubs of social resistance emerged, the independent press and publishing thrived, and other social undertakings were launched, including free trade unions. Although its range was rather limited, what was then dubbed "independent activity" encompassed incomparably more people and social groups than

151 This is highlighted by researchers such as David Ost and Michael Bernhard, who compared dissident movements across people's democracies. The strategy devised by Jacek Kuroń and picked up by Adam Michnik and the KOR proved very effective. Cf. David Ost, The Defeat of Solidarity: Anger and Politics in Postcommunist Europe (Ithaca: Cornell University Press, 2005). 
anywhere else in the neighbouring countries, in which only very narrow cultural elites were involved in the dissident movement.

The language of moral rather than purely political claims ("the politics of antipolitics," as David Ost dubbed it in his study of Solidarity ${ }^{152}$ ) demanded that the party-state restore and observe the rights of man and of the citizen, which the People's Republic of Poland had committed to doing by signing the Helsinki Accords. When social actors decided to undertake peaceable, reformist action against the system, they had a ready-made language at their disposal. And it was exactly this language of moral and political demands towards the party-state that the pope's first pilgrimage to Poland powerfully validated.

Another instrumental factor in the mental transformation was that the "young pope," John Paul II, recognised human and civil rights as natural rights given by God to all people and every human being. The relevance of this act to the dynamics of social thinking and action in Poland cannot possibly be overemphasised. ${ }^{153}$ It authorised what was essentially the moralist agenda of the democratic opposition. In fact, the Church's gesture of solidarity with the oppositional protest actions had been important even before the pope made his first trip to Poland in 1979.

Human dignity, the dignity of the individual and, in particular, the dignity of the working person were at the centre of the pope's teachings, as his later encyclicals reconfirmed. In this way, the strongly ideological and moral foundation of the social transformation movement and the interpretive framework of reality on which the movement relied were formed.

\section{The Organisation of Protest, the Birth of Civic Consciousness and Reformist Demands}

The evolving Solidarity unionist movement was, as we know, informed by the experience of the strike wave which surged across Poland from the spring of 1980 on. This had very practical consequences. In enterprises, organisational elites arose to represent the workforce, and across the country crews of different

152 See David Ost, Solidarity and the Politics of Anti-Politics: Opposition and Reform in Poland since 1968 (Philadelphia: Temple University Press, 1990).

153 Critics of John Paul II observe that, at the same time, he strongly opposed the liberation theologians and the activists who relied on their writings in South America, though they championed the same values as the trade-unionist movement in Poland. Cf., e.g. Przed Bogiem. Ze Stanisławem Obirkiem rozmawiaja Andrzej Brzezinecki i Jarosław Makowski (Warszawa: WAB, 2005), pp. 76-80 (with footnotes). 
enterprises began to collaborate. As these are well known facts, let us focus on the factors that made subsequent groups of workers and clerical personnel join the trade-unionist movement after the August accords were signed.

The definition of the situation which was commonly shared at the time can be summed up in two statements; "it can't go on like this anymore" and "we're all adults who can take responsibility for themselves and the country." There was no reason any longer to believe "them" - i.e. the party-state - as "they" had never made good on their promises. This courage to speak up on matters of import "to us all" would in all likelihood have been impossible without the alliance of workers and the intelligentsia, which had been ushered in by the activities of the democratic opposition and the first hubs of free trade unions. At least, the rapprochement achieved in Gdansk - or, more broadly, in the Tri-City - was a key factor in formulating the demands which far surpassed any demands that had previously been put on the table in Poland. ${ }^{154}$

Yet, the mindset insisting that people themselves (workers at an enterprise, residents of a town, entire society) could take responsibility for their shared life had already been in place. "Subjectivity" was one of the symbolic - veritably magical - words which were associated with the trade union movement. People's overriding take on things was that we had long consented to "their" total power (the agreements in Gdansk and Szczecin at the beginning of Gierek's tenure as First Secretary of the PUWP's Central Committee), but now we had to take care of our interests as workers and employees. ${ }^{155}$ It couldn't go on like this anymore.

Joining the trade-unionist movement meant "being adult" and thus having the right to take private and family life in one's own hands, to partake of common fate and public life and to have an impact on whatever determined individual lives, the operations of the state and the principles of collective life. Without that, it was impossible to influence responsibly one's own life. Decent life meant a life of a free person responsible for their life and co-responsible for the life of the socio-national community. The protest almost immediately transformed into constructive, future-oriented thinking and, soon, into positive action.

154 I was reasserted in this belief by the memoirs of Bogdan Borusewicz and his account of the organisation of the strike in Gdansk's Lenin Shipyard. Cf. Borusewicz: jak runat mur, ed. Edmund Szczesiak (Warszawa: Wolumen, 2005), pp. 125-140.

155 Illuminating insights are offered by Jerzy Jedlicki's somewhat undeservedly forgotten study of the Gierek-signed and other social contracts between the communist regime and society. Cf. Jerzy Jedlicki, Forma i treść “umowy społecznej," Wykłady Towarzystwo Kursów Naukowych (Warszawa: Niezależna Oficyna Wydawnicza Nowa, 1980). 
Individual dignity, human dignity, the dignity of the worker or, more broadly, of the employee became a fundamental concern. This can be explained in several ways, but the impact of John Paul II was certainly among the factors as his teachings were directly transplanted onto everyday social life. Of course, the propagandist slogans of real socialism and its rhetoric of workers' dignity also had their role in everyday life. Although the flagrant success propaganda was commonly viewed as a mockery of the touted "socialism with the human face" and "respect for the working people," certain elements of official ideology undoubtedly permeated into the popular mentality and could be usefully utilised, especially when a new interpretive framework of reality and individual lives appeared. The official propaganda's lexicon could be treated seriously and even used against the decision-makers in accusing them of hypocrisy and the violation of their own declarations and slogans.

The fundamental transformation of the mentality of workers - or, more broadly, of employees - who were all more or less involved in a game with the system, with their interests at stake, consisted in the budding of citizenship feelings, i.e. responsibility for one's own and one's family's life coupled with the belief that ordinary people were not only entitled but also obligated to discuss common fate, the system, the state's operations and the principles of social life. The respective interests and goals of workers, groups and industries were inscribed into a broader list of the goals of the socio-political community; they were re-considered as partial, but socially dovetailing, interests and demands.

It is crucial to grasp this accurately, because the word "solidarity" was one of the most important achievements of the new citizenship mentality forged in and through the social movement. On the one hand, the individual grew more significant as the belief spread that people were responsible and had equal rights; on the other, the idea was accepted that "others" (any "others") must have the same rights as "I" had, so it was imperative to constantly negotiate and agree with others on how to live and how to act in order to promote individual goalachievement as well.

This, of course, was very closely associated with the slogans of freedom. "Adulthood" reinforced the sense of individual dignity, and freedom accrued very specific meanings. Freedom was treated as a common value shared with others, while at the same time everybody could enjoy it individually. To make sure that people could finally decide about themselves and have an influence on the conditions of living, it was necessary to accept that others, compatriots, were free as well and thus could live as they liked.

The sense of "adulthood" and the desire to exhibit it in collective life made people feel that they were persons enjoying inalienable individual rights and 
responsible for their lives, but also that every other human being had the same rights, which meant that the ways and principles of communal life had to be discussed and negotiated with others. Without that, individual success was impossible. The sense of individual dignity and freedom engendered the sense of social subjectivity: not only the individual but also the whole of society was the subject of action. Society regained subjectivity as a community which should be able to determine its own fate, which meant deciding together about the principles of life, power, governance and the polity.

This, in turn, conferred a new value on politics. Politics was re-cast as participation in the shared fate and a condition of individuals' capacity to take care of their own and their families' wellbeing. Such participation and care were channelled through involvement in collective debates and trade-union activities. Politics, so to speak, capped the individual's decent, adult life and reasserted individual and collective subjectivity. Exalted though it may sound, Solidarity embodied something of the nearly ancient experience of politics.

Moreover, the experience of subjectivity and the intertwining of individual and collective goals may have stamped the peaceable character of the movement. Of course, the peaceable approach resulted, in a degree, from the fact that the party-state had force at its disposal. The memory of the regime's physical violence against the citizens, workers in particular, was acutely alive. This memory was especially vivid in Gdansk, where since 1977 more and more people had been taking part in illegal commemorations of the shipworkers killed in $1970 .{ }^{156}$ Organising strike protests, workers as a rule made sure not to give the regime any easy excuse to strike back with violence.

At any rate, social and individual subjectivity bred demands which fashioned a public life - a life of collective, social debate - which Poland under communism had not seen yet. Indeed, the Solidarity movement produced a space of public debate along with the noblest, most vibrant definition of politics we have ever had in Poland. Additionally, all this was strictly associated with the organisation of the trade union itself, which I will discuss below.

\section{Community: The Image of the Individual and the Civil Image of Society and the Nation}

In social terms, the new mentality entailed the emergence of citizenship: being a genuinely adult individual was equated with personal engagement in the

156 This is persuasively described by Bogdan Borusewicz; see Borusewicz. 
community of citizens whose debate should be taken into account by the state authorities and have a bearing on the governance of the state.

In this way, in thinking and experience, individual goals integrally concurred with common goals, and society, which had already developed a sense of group identity, had become a civic community and a political community. The social "we" was contrasted with "them," i.e. the authorities of the party-state, the opposition between the two enhanced to the utmost after martial law was criminally imposed. The "us"/society vs. "them"/the regime division was to persist practically throughout the entire decade of the 1980s. The concerted efforts of the general-led regime's ${ }^{157}$ to overcome this division all but failed. As a result, I argue, of the abortive conquest of its own society, the regime had to share its power to secure a rudimentary legitimation and an ability to govern effectively. We all know how these machinations ended.

The point to establish is what kind of community came into being at that time. Many studies of that period and the entire history of the Solidarity social movement posit that the sense of community was only temporary and defined by the confrontation with the power of the party-state. Such interpretations suggest that the trade union movement was, so to speak, glued together by negative mobilisation, i.e. by the popular protest against the party-state, its representatives and representations. Such opinions have been voiced in recent years even by the prominent activists of the Solidarity reformist movement, first and foremost by Lech Wałęsa.

However, I believe that such views are disproved by sociological explorations of Solidarity. If they were right, the outline of the new citizenship mentality above would be quite useless as a tool for analysing and explaining the dynamics of the events. For the rise of this mentality made the social protest movement morph into a mass reformist movement.

I argue that the unionist movement was guided by the ideas of social reforms from the very beginning and forged a mass social movement because of its positive agenda and positive goals. After the signing of the August accords, trade unions started to mushroom in enterprises and workplaces all over Poland, which was a testimony to the burgeoning of positive consciousness. This consciousness was expressed in an eagerness to join in the common work that was the Independent Self-Governing Trade Union "Solidarity." At the same time, every workforce or employee group which undertook practical activity formulated their own demands. It would be no exaggeration to call it a demands

157 The "general" here refers to General Wojciech Jaruzelski. (translator's note) 
movement. Wherever strikes or other protest actions had earlier been organised, demands had also been involved which, though not yet systemic, in fact targeted the system. When the agreements were signed in August 1980, demand-placing was energetically continued, and their scope was rapidly expanding. When the authorities of the party-state consented to people's independent self-organising, the previously ubiquitous fear subsided (albeit without ever vanishing) and demands proliferated, concerning first individual enterprises, then the entire respective industries and ultimately the practices of the state administration. Citizenship attitudes were quick to find a practical form in which to manifest and express themselves.

Research on the establishment of trade unions has shown that demands had an essential role in the social game between the organisers and first members of the new trade union on the one hand and the managements and PUPW organisations on the other. As a rule, in meetings during which a trade-union unit was set up, an array of demands surfaced as well, aiming to rationalise production and economic processes, to put it briefly. The very fact that the demands formulated by workers were generally rational suggestions for streamlining production and removing the absurdities caused by the central management and planning won them credit, if not always support, from the bodies that managed enterprises and production. ${ }^{158}$ From the very beginning, the demands movement ${ }^{159}$ showcased civic and political attitudes. "Politics" was defined as thinking together about the way to order and arrange the world, starting from people's closes environment, i.e. their enterprise. The twenty-one demands of the striking Gdansk Shipyard workers played a unique, symbolic function and provided a model of what was indeed worth fighting for. The demands made in enterprises, which were more and more appreciated by government-appointed directors, conveyed the evaluation of the situation in place. ${ }^{160}$ The courage of this assessment begot an increasing boldness to think and debate on what could be done

158 Ireneusz Krzemiński et al., “Trzy dusze dyrektorów," in Polacy - jesień '80 (Warszawa: Wydział Filozofii i Socjologii UW, 2005), pp. 155-163; p.94 volume.

159 The demands movement attracted the attention of researchers at the end of the 1980s. Cf. Ireneusz Krzemiński, Czego chcieli, o czym myśleli? Analiza postulatów robotników Wybrzeża z 1970 i 1980 (Warszawa: Instytut Socjologii UW, n.d. [1987]), pp. 1-89; Postulaty. Materiały do dziejów wystapień pracowniczych w latach 1970/71 i 1980 (Gdańsk, Szczecin), eds. Beata Chmiel and Elżbieta Kaczyńska (Warszawa: IPSiR Uniwersytet Warszawski, 1988), pp. 1-566.

160 Cf. footnote 6. 
to improve that situation; the conclusion was that increasingly general demands concerning increasingly higher levels of management must be put forward or, otherwise, not much could be changed at the very basic, local level.

Secondly, the community shared not only the assessment of the situation (which, in our 1980 study we encapsulated in the already cited catchphrase "it can't go on like this anymore"), but also the conviction that this situation could be rationally changed. The definition of dignity and responsibility presupposed that rational, or at least common-sensical, principles of action could be formulated to accommodate the interests of all the stakeholders involved, or at least not to disadvantage society (or workforce, workers of an industry, residents of a town or a region, etc.). This, in turn, entailed debating together on the best and most suitable solutions, in stark contrast to the previous practice of the party-state's i.e. the regime's - ideological prioritisation of its own interests. Additionally, the regime lacked sovereignty in two ways at least: it neither represented the real national interests (subordination to the USSR) nor allowed the system's to actors voice their own ideas and proposals (Party centralism). Now this was to change, and a "new thinking" was supposed to represent society's genuine notions and needs as well as, obviously, to be independent of the blatant pressure of any external power (the USSR). The belief that rationality and common sense were possible and that they were best manifested in a candid and heated collective debate propelled one of the most important organisational achievements of the Solidarity unionist movement.

When social and civil discussion on what to do and how to do it, on how and why governance should work (while the government wanted to obtain the social legitimation) was put at the centre of people's interest, the most peculiar organisational property of the NSZZ "Solidarity" appeared. I will address it in the following.

\section{The Wisdom of the Majority and the New Citizen Mentality: A Short Critical Digression}

Before I do that, however, let me focus for a while on another peculiarity, i.e. on the fact that evolving Solidarity and the developing social movement committed to the repair of the polity and society sought to make the practices of various, if not all, elements of the social system more rational.

At this point, it is indeed necessary to evoke Alexis de Tocqueville and his argument about the governance of the majority. In his influential Democracy in America, Tocqueville states: "The moral ascendancy of the majority is partly founded upon the idea that more enlightenment and wisdom are found in a 
group of men than in one man alone and that the number of legislators counts for more than who is elected." 161 Certainly, in their daily practice, Solidarity members thought that a view which was agreed on and shared by many was in a way wiser. At any rate, the Polish proverb saying that "two heads are better than one" was often evoked to emphasise how useful it was to agree on various issues, especially those related to common action, through discussion and negotiation. This could clearly be seen at the $1^{\text {st }}$ National Congress of Solidarity in Gdansk's Olivia Hall. Arguments reiterated by several speakers grew more powerful because, in line with Tocqueville's observation, individual wisdoms were aggregated into some collective "greater wisdom."

Of course, Tocqueville very insightfully mocks this naive belief and insists that, even if endorsed by an overwhelming majority, a view is only one view when it is shared by so many people. Consequently, another, contradictory view, even if only voiced by one person, must be regarded as equal if we try to establish what is right or true by weighing contrasting views.

Tocqueville's reasoning provokes an essential question: What was it in the deliberations and discussions across all the levels of the Solidarity trade union that forestalled "the tyranny of the majority," as Tocqueville puts it, i.e. prevented drawing practical conclusions from the belief that there was "more wisdom" in the majority's arguments?

There is only one answer. It was the organisation's unwavering adherence to the principle of equal participation in collective discourse, a cornerstone of that famous and yet so quickly forgotten ethos of Solidarity. Yet, emphatically, such a citizen mentality and such an ethos were neither unalloyed nor indisputable. The portrayal painted in the foregoing can be denounced for over-idealisation. Indeed, my account is an idealisation, yet in the sense of Weber's ideal type, rather than in the sense of bracketing off elements which inconveniently cofound the researcher's theses.

Given this, I will avail myself of research findings and primarily of Alain Touraine's studies. The point is that even if the foundations of that new citizen consciousness had been laid before the NSZZ "Solidarity" came into being and a powerful social movement formed around it, the very process of building trade unions was crucially instrumental in the ultimate rise of the citizen mentality. And the process was by no means smooth. For example, Touraine's studies in Gdansk very clearly show an important controversy about action strategies and

161 Alexis de Tocqueville, Democracy in America and Two Essays on America, trans. Gerald Bevan (London et al.: Penguin, 2003), p. 288. 
values behind them which later re-surfaced in the discussions at the $1^{\text {st }}$ National Congress of the NSZZ "Solidarity." In Gdansk, two different models of consciousness clashed over defining the basic, therein civic, interests and goals; later, we also came across a very similar problem in Warsaw. Sketched above, the citizen mentality and consciousness won and prevailed in joint thinking and action. Yet, arguably, it was formed in a clash with and against a far more "restricted" consciousness. In the latter, which could be described as a more worker-slanted mentality, the central matter was to define and prioritise workers' and typically trade-unionist goals. As an organisation, Solidarity was supposed to safeguard first and foremost workers' interests and living conditions, while the reformist demands that went beyond employees' direct interests were to be abandoned. This entailed curbing civil aspirations and envisioned the trade union as an organisation that stood up for the strictly defined interests of workers or at most employees as nearly all people in Poland, including a growing group of farmers, had full-time jobs.

Certainly, this was a class consciousness rather than a polity-and-citizenship consciousness. It was underpinned by and was far more vocal about the collectivist considerations. This should not come as a surprise; if the common movement and its trade union were primarily to protect workers' interests, it was imperative to be solidary in abiding by and defending them if jeopardised. In this sense, "solidary" meant a slightly different thing than what ultimately prevailed in Solidarity members' view and experience of the world.

Such discussions among Gdansk-based activists clearly showed a conflict between the two forms of trade-unionist consciousness, a conflict that was by no means easy to eliminate. In fact, by the end of the research project in July 1981, the conflict within the Gdansk group had not been fully solved. ${ }^{162}$ It later recurred in slightly different versions in various situations and research samples and often flared up in a, so to speak, more elaborate form as a clash of a more liberal and a more authoritarian varieties of democratic consciousness. ${ }^{163}$ Without

162 I report it as a member of Touraine's research team. To my knowledge, this information does not appear in other reports of this study.

163 This is how I described the situation elsewhere: "The axis of distinctions within this 'new consciousness' stretches between more liberal and more authoritarian attitudes. At one pole of our axis, the 'new consciousness' is bound up with a tolerant ethos of openness, spontaneously established rules of action and ongoing bargaining about what to do next, in what ways to do it and how to coordinate action; at the other pole, there is a less open and less tolerant ethos which prioritises group values and reputed authority, protects the 'group spirit,' insists on subordination to the 'collective will' in democratic mechanisms and invests more in controlling people's compliance with the 
a doubt, however, the more liberal model triumphed, as evinced, for example, by the controversy that took place in the Mazovia Region in late autumn 1981 between most representatives of the Region's trade-union units and a group of so-called true Poles. Though vociferous about their demands, the "true Poles" were unable either to intimidate the Region's trade-unionists and leadership or to de-rail the trade-union's contested procedures ${ }^{164}$ Tocqueville's tyranny of the majority was kept at bay by what he called the "habits of the heart." And these "habits of the heart" also obtained their organisational form when in the process of establishing and developing the trade union a very special procedure and an equally special formula of Solidarity's activity were engineered. The procedure and the formula served as a safety mechanism against the hazard of the majority's intolerance.

The habits of the heart were accessory, if not entirely pivotal, to it, all the more so that they proved to be something more than just momentary moods. The findings of studies carried out even in the communist period indicate a deep-running attachment of most Poles to the principles that prevent the tyranny of the majority. Namely, Poles profess to be particularly committed to pluralism in socio-political life, and pluralism entails the right to present beliefs and opinions expressive of minority points of view. Stefan Nowak's studies reported Poles' invariable endorsement of this principle, including the right to criticise the system in place. ${ }^{165}$

\section{The Independent Trade Union as a Laboratory of the Democratic State}

After this detour, let us return to our main track and focus on the crucial organisational, even structural, peculiarity that underpinned the activities of Solidarity both as a trade union and as a social movement. The peculiarity consisted in attributing utmost importance and the key role to regular meetings and discussions. Across all the organisational levels of the trade union,

rules than in mechanisms of instituting rules [...]. A 'more liberal democracy' and a 'more authoritarian democracy' are terms that best depict that fluid distinctions typical of the period." Cf. Krzemiński et al., Polacy, p. 124; comp. p. 94.

164 It would be interesting to establish in how far the divisive actions of the "true Poles" were orchestrated by security services. Today it would be possible to determine the extent of the impact of security services with some precision.

165 Cf. Stefan Nowak's studies in Ciagłość $i$ zmiana tradycji kulturowej (Warszawa: PWN, 1989). 
deliberations and debates were held to address the current problems of individual enterprise-based units, regional structures and nationwide bodies, including the National Commission. As a result, membership in the trade union also meant practical involvement in public debate. Debates and discussions organised common thinking and fundamentally affected collective views, which could not be ignored by the representatives and the elected leadership of the trade-union. Activists were uniquely constrained by the outcomes of debates among the members whom they represented in the union's formal structures.

The democratic structure of the trade union was rather complex, and had a special element of public debate built in into it. Prompted by the need to engage in joint action and by the special citizen ethos, ${ }^{166}$ debate also performed other functions. Importantly, the structure of the trade union should be viewed as a unique social experiment on a huge scale. The principles that were developed and implemented in practice as rules and procedures were supposed to be valid not only in people's own dream trade union. The Independent Self-Governing Trade Union itself was treated by a vast proportion of its membership as a laboratory for testing the principles for the state and political life. The trade union was its members' beloved child, for it grew stronger and kindled a hope that the civil fervour would help the democratic trade union grow into a democratic polity.

In this way, Solidarity as a trade union generated a new form of the democratic order. Admittedly lending itself to various descriptions, this form can be classified as participatory democracy. And if discussion and debate were put at the centre of people's direct action and engagement, it can straightforwardly be called debating democracy, ${ }^{167}$ a form of deliberative democracy, as it is known in sociology. Solidarity, in fact, not only created a space of and for public debate but also filled it with an original form rooted in the organisational practices of the Independent Self-Governing Trade Union.

This has important sociological implications concerning, for example, the reasons behind the disappointment and unfulfillment experienced since the onset of the Third Republic of Poland. ${ }^{168}$ Within this simple framework, we could

166 Despite Solidarity people’s vigorous linguistic inventiveness, "ethos” only appeared far later in the lexicon of significant symbols of the social movement.

167 While deliberative democracy (as well as discursive democracy) is a frequently used term, my coinage of debating democracy is supposed to capture the distinctive quality of Polish political participation.

168 The Third Republic of Poland (Polish: Trzecia Rzeczpospolita or III RP) is a widely used, though actually unofficial, term denoting the Polish state as re-built in the 1990 s as a result of the democratic transition initiated in 1989. The name points to 
argue that the Round Table, the election in June 1989 and later the formation of the first non-communist cabinet fuelled expectations of a revival of common, public debate.

Such expectations were still quite ardent in the mid-1990s. They were first associated with the Civic Committees (Komitety Obywatelskie), which were initially projected as an expanding forum of public, civic debate. Unfortunately, the Committees functioned in this way for a very brief period, only to be almost immediately subjected to straightforward political control along party lines. The process of reforms - of profound democratic and market reforms - took place without people without whom the political representation of Solidarity would have no say whatsoever after 1989. I believe that studies of the Third Republic do not attend closely enough to this general social frustration and foiled hopes for the revival of public debate as the fundamental instrument of political and social participation. It is a serious failing, for these sentiments were experienced by such an important worker group.

However, not only participation was at stake. Making public discussion an institutional part of the trade union did not simply express aspirations of participation or channel direct engagement in public and political action. It also assuaged the anxieties and fears of the expansive, discussion-brimming tradeunionist movement of social reforms. The permanent debate in which the trade union's activities and life were steeped was supposed to serve as a means of social control over the union's representatives and leadership. Experience had taught workers - or, more broadly, employees - that representatives were not to be trusted too much. They had seen all too clearly that in the exercise of power the governing were only too quick to leave the governed stranded and to evade the control of their voters.

At this point, we can usefully revisit the clash of more civic-minded and more worker-minded versions of solidarity consciousness. It was the worker class-mentality that prioritised class interests and insisted that workers - or, possibly, employees, but employees of a particular enterprise, occupation or

the re-establishment of independent Polish statehood after the hiatus of the German occupation during the Second World War and the post-war Soviet-controlled People's Republic of Poland (Polish: Polska Rzeczpospolita Ludowa or PRL). On this model, the Third Republic is a resumption of the Second Republic of Poland (Polish: Druga Rzeczpospolita or II RP, 1918-1939), itself called so to evoke the ties with the (Polish-Lithuanian) Commonwealth of Two Nations (Polish: Rzeczpospolita Obojga Narodów), which was partitioned by Russia, Prussia and Austria in the late $18^{\text {th }}$ century. (translator's note) 
industry - should take care of and fight for their interests, whereas excessive discussion was only counterproductive. Consequently, the movement should be organised as a trade union standing up for its membership's interests and rights, while the elected representatives and the leadership should be authorised to act firmly and decisively. Thus, they should be given power and obeyed in order to achieve common goals.

However, even this crude consciousness had an essential "but" to it: namely, this model also needed a quick solution to the problem of trust and confidence in the leadership. Even the elected bodies and representatives were not to be fully trusted, for the past had shown that such people were bound to compromise common interests and to succumb to the power drive over representation and the common cause. Consequently, debate had to be condoned as a way of finding out about the intentions of the elected people. Candid and open discussion was supposed to produce an overall agenda for the leadership and representatives to implement in practice. Public debate among the membership and the decisions it produced provided the basis for holding Solidarity's activists and leaders accountable. This is indeed what happened in practice.

What was initially an opposition between two models of the social order mutated in the daily practice of the trade union into a gradation, a compromise between the desire to have effective and obeyed leaders and the insistence on discussion as a means of controlling the leadership and consequently of restraining individual, arbitrary decision-making. In this sense Solidarity's debating democracy was a response to and a conclusion inferred from the past experience of betrayal by the Party, trade-unions and intelligentsia elites, which drove home the idea that even the freely elected elites had to be monitored. Erecting public debate and candid discussion into an institution also served as an instrument for achieving this aim.

\section{Conclusion: A Handful of Still Pertinent Insights}

When I revisit the past both as a researcher of and a participant in Solidarity's historical events, what I recall first and foremost is the atmosphere we breathed at the time and the feelings overflowing in both the private and the public social space. Despite lingering fears, optimism and hope were the strongest overtones of that emotional score, as attested by the active commitment of individuals and entire communities. The wave of activity surged far beyond the framework of the trade union, spilling onto various areas of social life, starting from the initiatives of occupational groups (which, for example, devised and adopted their own professional codes) and ending with local community and neighbourhood projects. 
The organised trade union movement certainly propped those various social pursuits.

Importantly, these pursuits were a channel for multiple individual fascinations and helped people realise their dreams and needs. In this sense, the general social movement provided a framework for individual aspirations and ventures. Still, its impact was even broader. For example, for some people the initial involvement in social actions did the groundwork for going abroad as a way of individual self-fulfilment. Certainly, in 1981 it was much easier than ever before to obtain a passport, not to mention a visa. And very many Poles concluded - especially after the $1^{\text {st }}$ National Congress of Solidarity - that they could risk going to Western Europe, for some time at least. Martial law changed most of these trips into emigration. By going West, I mean not so much people who left for fear of further developments (and since the beginning of the mass social movement more than few people had done that), as rather people who seized the opportunities provided by the pro-Polish atmosphere and went abroad for some time to realise their dreams and aspirations, previously unrealisable other than by escape. After the criminal imposition of martial law, such people and groups were actively involved in supporting Poland and Solidarity from abroad.

The rise of so numerous forms of human activity invites us to ask what factors fostered this invigoration. The overall situation in the country was far from comfortable as the proliferating reformist demands and the positive agenda of repairing public life clashed with the regime's confrontative strategy and endeavours to abolish the trade union. As a result, hope and optimism were permanently intermingled with anxieties and fears. For a sociologist, the situation presents a unique mass experiment which helps identify the factors that prompt people to undertake social and individual actions, risky though they may be. Such findings can illuminate the contrast between the citizen social movement as described above and the situation brought about by underground Solidarity's unexpected victory and the fall of communism.

One socially relevant conclusion would be that individual activity on a large scale can be expected in special conditions of perceived social support and social security. Individuals who involved in a range of risky actions - also those that could cause the system's counterstrike - were deeply convinced that they would not be left to their own devices if their undertaking failed. Arguably, the state-guaranteed system of social support was a far less significant factor, as it was criticised, questioned even, as failing to perform its nominal functions. Rather, the conviction that nobody was left alone and that everybody could count on help and support within institutionalised social actions 
was engendered by the prevailing sense of social community and participation in the common cause. People felt that they would not be left to fend for themselves as there were advocates and defenders who would offer one form of help or another. This disproves the notion that people undertake initiative and are inclined to involve in potentially precarious actions and activities only if pressed by necessity; in such situations they are likely to desperately catch at straws, which has little to do with well-informed, though perhaps somehow iffy, actions for the sake of change. Individuals' pro-activeness and inventiveness, even in their private matters, seem to be largely triggered by that sense of social support.

As a sociological generalisation, this insight must be complemented by the role of social symbols in kindling this sense of vibrant social community. The fact that a powerful trade-unionist movement called itself Solidarity - that it could use the word and the notion expressing the awareness of active social community - was rooted in a broader symbolic tradition. In my view, the grounding of the so pointed communal awareness and self-awareness of Poles can be traced back to the intelligentsia's gesture of solidarity with workers in 1976, which saw the foundation of the KOR, followed by a broader democratic opposition. In this gesture, the goals and interests of "those on top" and "those at the bottom" coalesced into one nexus from which the symbol of Solidarity was carved.

The degradation of the memory of Solidarity in free Poland, which is referred to as the $3^{\text {rd }}$ Republic of Poland, results perhaps from the fact that the active reformist elites have abandoned this symbolic framework and altogether ignored that symbol of community. Since the Round Table talks, the meaning of Solidarity, which re-emerged as a legal organisation, as a symbol of reforms and as a meaningful social actor, has been re-defined. The social actor was, basically, important, but its duty was to support reforms rather than initiate and participate in the democratic re-structuring of the polity. The symbolic legacy was treated entirely instrumentally by the new political elite stemming from the Solidarity movement. The project of participatory democracy or debating democracy (if, never fully articulated, it deserves the name of the project in the first place) has never been realised, because people who were an important part of the community which designed it have embraced other modes of thinking and other models of the state and socio-political life. It does not mean, of course, that his model, vague though it may have been, was absent from new social expectations and actions. I believe that the interpretive framework I am outlining here perfectly accommodates and is corroborated by Grzegorz Ekiert and Jan Kubik's studies of Polish protests in the first years of the new 
democracy. ${ }^{169}$ Ekiert and Kubik have shown that the popular protests sweeping across Poland soon after the new polity model was implemented and reform policies were launched can and should be viewed as an outlet for the otherwise blocked need for participation.

Another sociologically relevant factor, in my view, has been a transformation in the attitude to politics among an important and influential part of society, coupled with the atrophy of that unique communal individualism. Solidarity was saturated with the nearly ancient notion of democracy as civil participation, in which the individual's good, mature and satisfying life reached its culmination. This went hand in hand with the perceived connection between individual effort and activity on the one hand and other people's and society's fates on the other.

All relevant research to date, most emphatically the studies by Mirosława Marody, ${ }^{170}$ have reported that in free, democratic Poland, another model - one of egoism, rampant individualism and non-communalism - has taken sway. Such a model poorly supports collaboration even if clearly defined group aims are at stake. Such developments beg an explanation, and one part of the explanation must point to discarding the model generated by Solidarity. In my view, the process has not been properly examined by Polish social scientists, and accounts that we have, such as Jadwiga Staniszkis's studies, only concern selected - and institutional rather than mental - aspects of the transition. To offer such a comprehensive account lies beyond the scope of this essay, which aimed to describe the rise and significance of Solidarity. I have no doubts that, even though blurred in social consciousness now and corrupted by various instrumental interpretations, that experience still bears a highly positive symbolic potential embodied in a vision of an open and active society united by communal individualism.

169 Grzegorz Ekiert and Jan Kubik, Rebellious Civil Society: Popular Protest and Democratic Consolidation in Poland, 1989-1993 (Ann Arbor: The University of Michigan Press, 2001), p. 278.

170 Mirosława Marody (Ed.), Oswajanie rzeczywistości. Między realnym socjalizmem a realna demokracja (Warszawa: Instytut Studiów Społecznych UW, 1996). 



\section{Revolution, Solidarity and Words}

\section{The Language of Solidarity}

Only few studies examine the language of the Solidarity trad-unionist movement, the dynamics of language changes and the discourse in which the movement was engaged from its very beginning. Some studies depict the first outcomes of the social mobilisation, that is, the demands which were endemically formulated during the protests and, later, while establishing free trade unions. ${ }^{171}$ However, language as such - in particular oral language - has largely remained underexamined, except perhaps the symbols, which have been addressed by, for example, Jan Kubik ${ }^{172}$ and this author, who analysed significant vocabulary used by the mobilised people to define the social situation. ${ }^{173}$ To my knowledge, there is only one Polish study devoted to workers' language within Solidarity. Published (like other chapters quoted in this chapter) as an uncensored scholarly publication in only one hundred copies, the study was authored by Anna Błaszkiewicz and entitled "Świadomość społeczna robotników a językowe

171 Ireneusz Krzemiński, Czego chcieli, o czym myśleli? Analiza postulatów robotników Wybrzeża z 1970 i 1980 roku (Warszawa: Instytut Socjologii UW, 1987) (an uncensored, mimeographed manuscript); Beata Chmiel and Elżbieta Kaczyńska (Eds.), Postulaty 1970-71 i 1980. Materiały do dziejów wystąpień pracowniczych w latach 1970/71 $i$ 1980 (Gdańsk, Szczecin) (Warszawa: NOWA, 1998) (a manuscript). For discussion of the trade-unionists' demands, see also David Ost, The Defeat of Solidarity: Anger and Politics in Postcommunist Europe (Ithaca: Cornell UP, 2005); Michael H. Bernhard, The Origins of Democratization in Poland: Workers, Intellectual, and Oppositional Politics, 1976-1980 (New York: Columbia UP, 1993); Jeffrey C. Goldfarb, After the Fall: The Pursuit of Democracy in Central Europe (New York: Basic Books, 1992); and above all Jan Kubik (see the following footnote).

172 Jan Kubik, The Power of Symbols Against the Symbols of Power: The Rise of Solidarity and the Fall of State Socialism in Poland (University Park, PA: Pennsylvania State UP, 1994).

173 Ireneusz Krzemiński et al., Polacy - jesień '80 [1983], Socjologia Niezapomniana, vol. 3 (Warszawa: WFiS UW, 2005), see particularly pp. 126-164. The book also contains other studies which mention and analyse language-related issues. Henryk Banaszak discusses the language in which daily newspapers described the social situation, and the last section of his contribution is entitled "semantic manipulations." Grzegorz Bakuniak's chapter also relies on language analysis to offer an account of the fundamental mythology of the Solidarity social movement. 
formy jej uzewnętrzniania" ("The social consciousness of workers and its linguistic expression forms"). ${ }^{174}$ I will not summarise Błaszkiewicz's argument here, because my aim is to recall and record another experience, one involving broadly conceived language issues in the Solidarity social movement.

Discussion and debate were the fundamental avenues of participation in the unionist movement of Solidarity. In fact, talking, deliberating and conferring formed Solidarity's basic mode of being. Common discourse can even be said to have been one of the movement's major modi operandi. Talking together actually meant thinking together. The movement developed its own notions and re-defined existing words, investing them with new meanings. The acquisition of a new vocabulary was of paramount relevance in the social process. The production of the movement's own language, of its own speech which countered the party-state's ideologised, ritual speech, was one of Solidarity's greatest achievements. To grasp this in the theoretical language of sociology, we can usefully draw on George Herbert Mead's concepts and symbolic interactionism to conclude that such concerted common action produced and, at the same time, was made possible by significant symbols, i.e. by notions which imbued action as such with order, motivated people and helped them undertake their own initiatives within common action.

In this context, George Herbert Mead's concept of the universe of discourse also comes in handy. The universe of discourse is, briefly, a lexicon of the social community which delineates this community's cognitive perspective.

There is, however, another important aspect to it. As seen by individuals, the "solidarity" community prompted, if not forced, people to undertake cognitive and linguistic efforts since, in order to feel at ease in the new role of a debating trade-unionist and citizen, one first had to learn to speak in public and to develop skills of persuasion, argumentation and counter-argumentation. Such competencies were indispensable to voice one's ideas and propose demands for public discussion.

To begin with, I will resort to a personal story associated with researching the trade union movement. In the initial stage of building free trade unions in Warsaw, social committees were set up to help people establish an independent trade union at their respective enterprises. Information chaos was rampant, and it was

174 Anna Błaszkiewicz, “Świadomość społeczna robotników a językowe formy jej uzewnętrzniania," in Poza granicami socjologii ankietowej, eds. Antoni Sułek, Krzysztof Nowak and Anna Wyka (Warszawa: Uniwersytet Warszawski, Polskie Towarzystwo Socjologiczne, 1989). 
additionally fuelled by the regime's agencies and special services, which sought to frighten and discourage people from starting trade unions in workplaces. Given these circumstances, legal and organisational advice was in high demand, especially that both judiciary knowledge and practical action models were largely lacking. I served pro bono at one of the consultation points. ${ }^{175}$ One day, I went to a small town in the vicinity of Warsaw to take part in a meeting at a local factory. The meeting was organised by an activist involved with the KOR (Workers' Defence Committee), who planned on founding an NSZZ "Solidarity" unit at the factory. The late meeting with a dozen or so workers was a difficult one. I tried to explain to them in the simplest but most encouraging terms what freedom of association was, what procedures were involved in establishing a trade union, and how self-organisation worked. The workers commented on what I was saying, but I could only understand very little of the conversation. I kept repeating what I had to say, but the worst part was that I did not understand two or three questions they asked of me. Finally, the floor was taken by an informal leader of the workers' group whose opinion mattered a lot. My guide and the organiser of the meeting explained to me what the questions were all about. This shows vividly the gap between the Polish spoken by the intelligentsia and the colloquial Polish spoken by the workers, a gap I found surprising at the time. The misunderstandings were not caused by any dialect differences, but by the variance of my language and the workers' local jargon. This is not yet the end of the story. Almost a year later, I met some of the workers with whom I had talked back then in November 1980. Already members of the NSZZ "Solidarity," they reminded me of the meeting themselves at a gathering held in the wake of the trade union's congress. ${ }^{176}$ This time, our conversation was smooth and ran in beautiful Polish. The gentlemen told me that after the meeting they had resolved to set up an NSZZ "Solidarity" unit in their factory and, to my surprise, thanked me effusively. The man I had not been able to understand back then was now the most articulate orator of them all.

The story pictorially shows the changes in people's language. Undoubtedly, it was participation in the Solidarity movement that stimulated people's linguistic and thus mental development. Eloquent, expressive Polish replaced speech based on non-finite clauses and a rudimentary vocabulary.

175 The consultation point was situated at the office of the Club of Catholic Intelligentsia and the editorial board of Więź.

176 The $1^{\text {st }}$ National Congress of NSZZ "Solidarity" in Gdansk in 1981. 
Words, including literally poetic words, seduced and thrilled workers. A recurrent theme addressed at meetings with workers and other employees when setting up a trade union in their enterprise was the Nobel Prize for Czesłąw Miłosz. ${ }^{177}$ People construed their prior ignorance of there being a Polish poet who had won the world's most prestigious literary prize as humiliation by the regime, a token of the ideologisation of the state and evidence of an ideological bias in schooling. The demand for Miłosz's poetry was enormous. The demand for words of truth, for truth as such and in particular for historical truth became one of the most important engines propelling the personal growth of many trade-unionists. This was especially visible in the martial law period, when several translations of historical literature, unavailable in Poland before, and works of political theory and philosophy were published in samizdat. Relatively well educated big-industry workers were among the major purchasers of such publications.

The very notion of the Solidarity social movement is interesting in itself. At the time, the purely sociological notion of a social movement was not popular in Polish sociology, preoccupied as it was with liberal democracy, civil society (the democratic opposition's slogan as discussed by American Solidarity scholars Ost, Bernhard, Goldfarb and Kubik) and social mobilisation rather than with social movements. The concept appeared within the movement itself as its self-identification. "We are a social movement" would be proudly reiterated by workers whom we sampled for the study conducted by Alain Touraine, who himself augmented research into social movements with his original methodology. But the candidates to our discussion teams had referred to themselves as a social movement even earlier. ${ }^{178}$

As social activities progressed, various words and notions were gaining popularity; importantly, in most cases they were serious words associated with intellectual discourse. Towards the end of Solidarity's legal period, one of the favourite words was the Latin consensus, which fully deserves to be regarded as the trade union's significant symbol at the time. It was common currency in fact. In late November 1981, I took part in a meeting of an NSZZ "Solidarity" unit assembling caretakers for apartment houses in Warsaw’s Ursynów (practically, they were all women responsible for the cleaning and maintenance of the houses

177 Czesław Miłosz, a poet and essayist, was awarded the Nobel Prize in Literature in 1980. (translator's note)

178 I discussed the issue elsewhere, pointing out that the sociological notion had been "called forth" by people involved in action even before it came to be used in earnest by Polish sociologists. See Ireneusz Krzemiński, “Solidarność - organizacja polskich nadziei” in Solidarność. Wydarzenie, konsekwencje, pamięć, ed. Antoni Sułek (Warszawa: IFiS PAN, 2006), pp. 13-34. 
owned by the housing cooperative which overlapped with the developing metropolitan residential neighbourhood). I was astonished to hear how often the word consensus was used over the 1.5 hours of discussion by the members, most of whom had basic trade education at most. The word "consensus" was used quite correctly, and the discussion concerned the trade union's prospects, which were not deemed particularly promising.

These anecdotal examples must stand for empirical data as there are no studies that systematically registered the development of the "solidarity" language and rhetoric. Certainly, "subjectivity" was one of the most important notion used and perhaps also abused - by the movement members. To a degree, "subjectivity" organised Solidarity members' speech in general, being one of central significant symbols of the movement and a basic element of its universe of discourse. Subjectivity involved freedom of speech and freedom of expression and, as such, was associated with the imperative of tolerance, which meant that everybody had the right to speak out, no matter what views they held. As such, subjectivity was also intimately connected to the word "democracy," because without individual liberty and freedom of speech no democracy was thinkable.

With all its linguistic and extra-linguistic implications, the word "subjectivity" became functional owing to Pope John Paul II, who addressed his compatriots in a very specific language revolving around subjectivity. The first trip of John Paul II to Poland in 1979 profoundly affected the conditions which fostered the phenomenon of the Solidarity social movement.

The Pope's words founded a new discourse, a new universe of discourse, in which the central role belonged to the human person, whose rights were naturally guaranteed, i.e. instituted and bestowed on people by God the Creator himself. Of course, the Pope also appealed to the national community and the nation's right to constitute the state, but the national community was conceived as by definition securing civil rights and liberties. More than just a product of social will, civil and human rights were evoked as the crux of social relationships which ensured that people had opportunities to engage in responsible action. The Pope's words about freedom, which these rights afforded to human beings, were highly influential as well.

Indeed, the Pope's public speeches were deeply inspiring and even formative of Poles' later actions and thinking. All this was augmented by the impact of other words, specifically, the words used by the activists of the democratic opposition and the words which Poles could hear when listening to Radio Free Europe, Voice of America or the "Polish" BBC. The broadcasters were also instrumental in the rise of a new social consciousness and in the production of language that mobilised for action. 



\section{In the Grip of Pernicious Politics}

\section{The Social Problem Turned Political Problem}

Low and still decreasing voter turnout, the widespread belief (substantiated by several outrageous examples) that politics is just a playground where parasitic, socially alienated party oligarchies vie for their own interests (with the polity as one of the spoils to be seized), the meagre rates of public engagement in NGOs and general non-involvement in activities which practically enact the principles of social solidarity, all these are but a few of the symptoms that bespeak Poles' growing withdrawal into privacy and refusal to participate in public life. What are the causes behind this increasing passivity and reluctance to take responsibility for the res publicae? Does this particular escape from civic freedom result from disappointment with Polish democracy, deficient as it is, or does it perhaps reflect a broader crisis of civil society which plagues the entire Western world (therein the US, the cradle of modern republicanism)? The Third Republic of Poland was founded on the idea of solidarity; what have we lost of the precious experience of social solidarity since then?

These questions are addressed day in day out in scholarship, in journalism and even in our daily lives. ${ }^{179}$ Yet they are explored and answered on an ad-hoc basis and are perennially entangled in the current political disputes. It is no different in academia, where ideological, if not downright partisan, allegiances show through in sociological and theory-political studies, while scholars seek to give their conclusions an objective ring by sticking to commenting on surveys and public opinion polls. As such, scholarship also proves to be bedevilled by crisis. What we need is a broader and more detached scrutiny of the ten years of our democracy, surveying the previous developments and processes through a lens untainted by party loyalties and interests.

To refer to Solidarity in this context seems of paramount importance to me. By common consensus reported in empirical research, the People's Republic of Poland is now believed to have actually collapsed in $1981 .{ }^{180}$ Therefore, in order to

179 The original article answered the questions posed by the editors of Znak in the early 2000, which encouraged many authors to share their reflection on civil society in Poland after 1989.

180 A study we carried out in Mława ans Szczeciek in 1997 provided ample corroboration of this thesis. Cf. Ireneusz Krzemiński and Paweł Śpiewak, Druga rewolucja w małym mieście (Warszawa: Oficyna Naukowa, 2001). 
understand the average Pole's present distrust of democratic politics and democratic polity, we need to go back to the Solidarity social movement. Also, we need to explore how the dark decade of martial law affected Poles' representations of politics, citizenship and the state. We will not get far if, in exploring the effects of this unbearably protracted martial law, we only focus on holding - or, for that matter, not holding - to account the generals and party secretaries who eventually ceded their power (even though, undoubtedly, the issue of answerability must be addressed).

In this chapter, I argue that the peculiar lack of active support for democracy and the disinclination to civic participation (even to its rudimentary forms such as voting) ${ }^{181}$ which have been displayed by a considerable part of Polish society since the onset of the Third Republic, are outcomes of two overlapping approaches. One of them can be called an idealising and the other a cynical approach to politics, politicians and polity. The former is rooted in the ideal of democracy which was championed by the Solidarity social movement when it was taking shape in 1980-1981, while the latter originated in the experience of the crackdown on the reformist, trade union movement and the mode in which political authority was exercised by the last military cabinet of the People's Republic of Poland. These developments were also powerfully affected by the political activity of the Church in the early 1990s, which reinforced the negative, anti-citizenship strands within the two approaches (where anti-citizenship means simply an utter reduction of participation in and responsibility for the new socio-political order). However, no accurate and inclusive account can possibly overlook the Church's merits in bolstering citizenship and civil attitudes. Let us start with Solidarity.

\section{Solidarity and an Idealising Vision of Politics}

Most sociologists consider the vast trade-unionist movement of Solidarity to have been a significant episode, but hardly anything else - or more - than just a prolonged social festival, celebrating the solidary endorsement by Poles of shared values opposed to the communist regime. The ensemble of those shared values was not, at any rate, too numerous and represented mainly general personalist, national and above all socialist assertions turned, paradoxically perhaps, against real socialism. In this framework, the socialist investment was especially

181 Notably, voter turnover rates, especially in local elections, are very low in Poland, in fact lower than in the Czech Republic, Hungary and even Bulgaria. 
embodied in the philosophy of the dignity of the human person, even in its version preached by Pope John Paul II. Of course, this species of socialism was different from what Poles were experiencing as socialism in their daily lives. The motley blend of liberal, conservative and socialist slogans could be sustained, because it was unified by opposition to the common enemy and by the societyand-nation's shared will to be able again to determine their fate. Confronting communism and the communists blurred all differences and powered utopian visions of democracy and the free market as a system in which all people lived good and tolerably affluent lives. No wonder, thus, claim my learned colleagues, that when democracy and the free market unexpectedly became a reality, the common enemy disappeared and with the enemy gone was the alleged community of values as everybody started to pursue their own interests - interests that quickly proved to be entirely disparate. In such circumstances, the socialist overtones of solidarity thinking surfaced again in workers' protests against the market reforms, which they purportedly accepted, and in the demands of state interventionism, which contravened the free market principles.

The truth is, as most sociologists are eager to remind us, that a new economy cannot possibly be built without incurring social costs. The ill-advised demands made by the group-laid-off workers imply that they in fact neither understood nor endorsed the principles of modern democracy. Hence their distrust of the democratic state and politics, therein of political parties, coupled with their attachment to trade unions, which anachronistically protect workers and, in this way, hinder the dismantling of the remnants of the equally anachronistic welfare state. This portrayal seems very inaccurate to me, yet it is actually what most frameworks that explain the Polish transition (as sociological parlance has it) boil down to. In contrast to them, I want to propose an entirely different vision of the Solidarity movement and its impact on social mentality and popular consciousness.

Solidarity was born in protest, but it was not protest as such that fuelled the dynamically growing organisation of the social movement, which was joined by millions of people. The significance of Solidarity's trade-unionist organisation is notoriously ignored. Equally ignored is the role of the Solidarity experience as a practical lesson that taught millions of Poles how democratic principles could actually be applied. Solidarity was a powerful organisation which gradually produced a special democratic order. What was more or less effectively practised within and by the NSZZ "Solidarity" was, in fact, a project of a new social order and an ideal of a new state that was to oust the People's Republic of Poland.

Some Solidarity activists were fully aware of this fact. Zbigniew Bujak, for one, had the social imagination enough to observe as early as in 1981 that the 
trade unionists distrusted representative democracy. It was indeed the case, and the project of a new democracy included not only the basic, classical, Western principles. It also contained a corrective, a fact that was actually quite soon perceived in the West, particularly by American and British Solidarity scholars (not in Poland, though...). Sociological and theory-political studies started to dwell on participatory democracy. The shift was largely, though not exclusively, precipitated by the developments in Poland (not exclusively because it was becoming obvious worldwide that highly institutionalised and petrified democracies had slid into crisis).

The democracy project which was devised and quite extensively practised by the Solidarity movement within its trade-unionist organisation presumed institutionally sanctioned, broad participation of ordinary people - trade-unionists and citizens - in defining the social situation and the directions in which to move. More than that, the idea was that the rules and strategies of action should be established in and through public debate by discussion and the clash of views. The institutionally authorised form was provided by common social debate, which was by definition open and public. Actually, in the wake of marital law, the trade union's self-criticism often targeted that all too open, public model of strategic decision-making, which the trade union's apparatus was largely obligated to uphold. Trade-unionists exerted close control over their elected representatives by means of frequent meetings and regular debates, which were often inspired by the trade union's press.

Debating went on incessantly within Solidarity even in the autumn of 1981, i.e. in the last legal days of the trade union, and was very vigorous despite the growing disappointment of the members, while regular gatherings of enterprisebased trade-union units, regional bodies and all other agencies, including the trade union's headquarters in Gdansk, were numerously attended by common people. Certainly, the unionised workers, or just employees, did not fully trust their representatives and decision-makers, which stirred them to put in place institutional forms of control. ${ }^{182}$

By doing so, they also added a new quality to democratic principles by considerably expanding the participation of rank and file in strategic decision-making. This pursuit was impelled by people's long-lasting experience of betrayal by

182 I wrote these words long before the study we carried out in 2010 among the members of the "first" Solidarity, the findings of which provided indisputable empirical evidence corroborating this observation. The research confirms that most trade unionists took part in discussions that were continually taking place within the NSZZ "Solidarity." 
elected and trusted representatives. This largely explains the recurrent waves of anti-intelligentsia rhetoric in Solidarity.

If this enlarged participation is viewed as part of the democratic polity project, we should notice that it entailed defining the politician as a representative of the will and voice of his/her electors. Before embarking on any action, the thusdefined politician was socially expected to discuss it, at least with those most affected by particular decisions and activities. The political process of governing and decision-making was supposed to be guided by public opinion, by the voice of the people, so to speak. This was where the democratic politician differed from the regime politician. After all, the sense of citizenship grew around the consciousness of co-responsibility not only for oneself and one's family but also for the entire country and people's common fate. The right and possibility to speak in discussions on matters of importance for the community was an inherent and nearly ancient - part of the sense of the individual's dignity as a citizen.

The expectations associated with this participatory model of democracy were revived when the system unexpectedly changed in Poland. Intertwined with them, the hope for re-igniting public debate on the reforms was particularly fervid among the portion of society that had been - more or less actively involved in the underground activities and in the Church's varied social pursuits. By this, I do not mean the hardcore underground activists, for their number had been plummeting towards the end of the 1980s, while remarkably numerous groups of people simply continued to deny the regime any support. The hopes of those groups were immediately re-kindled at the beginning of 1989. The first institutional form for channelling them, other than through the re-established trade unions, was offered by the Civic Committees, which came into being particularly fast outside big cities, contributing to the re-construction of Solidarity's shattered trade-unionist structures. Once the trade union was re-registered, a broad discussion movement started to re-emerge gradually.

However, the path that the reformist elite, above all Lech Wałęsa, took - both when preparing for the general election in June 1989 and later under Tadeusz Mazowiecki's new cabinet - precluded the revival of the Solidarity social movement on as grand as scale as it had boasted before marital law. The Civic Committees were manipulated in ways that effectively prevented them from transforming into institutional incubators of reborn civic life or, later, of spontaneously formed political parties.

The reason was that public debate - fair and thorough discussion on how to re-structure the polity and build democratic and market institutions - was the last thing wished for by (oh, the irony of it!) the new, democratic authorities, which allegedly represented social ideals and common interests. The reverse was 
in fact true: the government was resolved to take advantage of society's enthusiastic consent in order to, possibly quickly, implement macrosocial and macroeconomic reforms, assuming in advance that this particular implementation mode could not but cause considerable social costs for and dissatisfaction in a considerable part of society. But because the belief was that the new economic rules in the democratically re-built state would as if by default compel people to adopt proper adaptive behaviours and most, if not all, people would ardently join in building the market economy, the transition period was expected to be relatively short.

This belief underpinned a new tendency embraced by the elite that hailed from a broad democratic movement, namely, its growing elitism. The belief that the necessary reforms had to be imposed on people and launched without any public discussion was reinforced by dogmatically endorsed liberal philosophy, which implied that since market-specific behaviours were natural to people, the creation of macroeconomic conditions of the market economy in Poland would automatically trigger individual and collective adaptive responses. As a result, the situation of people initially disadvantaged by the reforms was soon to change for the better, though ultimate success depended on their individual undertakings.

This is what I am inclined to consider one of the two original sins of reborn Poland's newly reinstated democracy. Foiling the expectations of participation, of replicating common, public civil debate, counts among the most important causes of social frustration, dissatisfaction and disengagement from the state displayed by masses of Poles. The tarnished hopes for participation are a major component of bitter attitudes to democratic institutions reported in sociological research, as shown, for example, by Mirosława Grabowska. ${ }^{183}$ A study I conducted with Paweł Śpiewak in two small towns rendered similar findings. In 1997, their populations reported the widespread feeling of non-participation in the process of economic reforms and building the modern state, coupled with the belief that the elected bodies, including those at the local level, failed to take their opinions into account adequately. ${ }^{184}$ Apparently not much had remained of the strong feeling, prevailing in the "first" Solidarity period, that citizens as a whole - i.e. ordinary people and their elected representatives - could and should

183 Mirosława Grabowska, “Demokracja - teorie i społeczne nastawienia," Civitas 2, 1998. Cf. also Mirosława Grabowska and Tadeusz Szawiel, Budowanie demokracji (Warszawa: PWN, 2001).

184 Krzemiński and Śpiewak, Duga rewolucja. 
create politics and governance rules together. Moreover, the clash of the democratic participation project, which I called an idealising vision of democracy and politics, with the practices of the emergent political elite very soon bred not only disappointment, but also a growingly negative definition of politics and politicians. Eventually, this put people off any attempts at participation, made them withdraw from public life and dented their aspirations of citizenship. ${ }^{185}$

\section{The People's Republic of Poland, Martial Law and a Cynical Vision of Politics}

The begrudged exclusion of citizens from the transition process coincides with ordinary people's withdrawal from politics, which is defined as evil and dirty. This indicates an overlap of two ways of defining the world and motivating individuals' behaviours. The bitterness of derailed expectations, which had been stirred by the idealising interpretation, was exacerbated by the opposite tendency, shaped by the experience of the forceful demolition of legal Solidarity under martial law. In the idealising interpretation, Solidarity had been seen as a spirituality-underpinned mass social movement which substantially contributed to culture and elevated individuals' everyday experience to moral heights. Consequently, the victory of the militarised PUWP over the peaceable movement could not but breed negative spiritual outcomes. In socio-psychological notions, they can be described as the demise of the concept of politics as democratic representation, common debate and a peaceable negotiation process, participating in which crowned human dignity, freedom and responsibility for the private and public life. This noble vision could not but (and indeed did) seem to many people a fantasy which fell like a house of cards when clashing with the tanks that the militarised communist regime sent onto the streets of Poland.

Probably even in the period which sociologists tend to depict as "festive," a social majority had already adopted the attitude I describe below. At the time, however, nobody was too eager to divulge such a viewpoint. When the generals triumphed over the peaceable movement, that attitude was bolstered and

185 Continued by the Centre for Research on Solidarity and Social Movements and the European Solidarity Centre, studies of the members and activists of the NSZZ "Solidarność" show that a large part of the respondents believe that some of the "first" Solidarity activists betrayed its original idea by preventing common, public discussion. The respondents believe that the sweeping political and economic reforms were launched without adequate public debate, an opinion articulated both by the advocates and the detractors of the reforms. 
disseminated. Despite daily resistance to the violence-based exercise of power, the experience of the 1980s triggered growing hopelessness and resignation or adaptation - to the power. A new, cynical concept of politics was a direct outcome of these processes and a specific culmination of the long martial-law period.

I call by this name the entire decade of the 1980s, from the imposition of martial law to the Round Table talks, because these years practically form one period. Although formally martial law was lifted relatively quickly, the curfew was repealed, and people were no longer advised on the phone that their conversations were listened in on, nobody had any doubt that the phones were still tapped and that when being out at night one was bound to bump into more than one military and/or militia patrolling squad. The mechanisms of the exercise of power did not change in the least.

People had to adapt to the situation, which encouraged cynical interpretations of politics and fundamental social relationships. The cynical vision of politics was in fact a far more general representation of power in society which said that one had power if one had force. Power meant domination and the ability to order and command others, imposing one's will on them. As such, power necessarily entailed violence and money, for violence is costly and sometimes requires procuring (buying) support. Money and force came to be seen as closely interrelated.

At the same time, however, the new philosophy of power and politics presupposed a possibility - a necessity even - to engage in a game with violence- and force-wielders, be it for the sake of avoiding or weakening their blows. Money, an attribute of power, could thus help influence power. At any rate, the violence-based power was prone to corruption and not averse to manipulating its own harsh principles in order to reap immediate gains which were necessary to keep various spheres of life going. ${ }^{186}$ As time went by, the social game with the system expanded and developed, focusing predominantly on retaining the little comforts of life achieved in the Gierek decade "of plenty" and now jeopardised by the deepening stagnation and calamitous socio-economic developments (e.g. growing fears of environmental pollution dramatically exacerbated by the Chernobyl nuclear disaster). Weaselling was the basis of daily life and meant morally dubious behaviours because, even though people generally neither

186 This was superbly illustrated by Jan Tomasz Gross in his Polish Society under German Occupation: The Generalgouvernement 1939-1944 (Princeton and New York: Princeton University Press, 1979). In an aside, this book sketches a rather different portrayal of Polish society than Gross' Jedwabne study. 
accepted the regime nor considered the government legitimate, they showed submission and hypocritical respect in order to obtain various minor individual privileges. This made life easier and more comfortable.

The 1980s was a time of reviving and using all kinds of family connections in order to secure everyday goods and more long-term profits. This was a decade of organised queueing and trade-focused international tourism, as recorded not only in sociological studies of Jacek Kurczewski but also in some truly poignant artworks (such as songs and cabaret pieces of brilliant literary quality). They registered people's withdrawal into family life and the privacy of their homes, which ran counter to any broader social engagement, excepting perhaps church-related activities. But even in such pursuits only a minority displayed truly pro-active attitudes.

Such experiences wrecked any thought of politics as a site of individual selfrealisation which capped a mature and responsible life of a social community member. Politics began to stand for the desire to rule others and the capacity to use violence combined with avoidance of its consequences and skilful submission to power in order to achieve one's own ends. As such, politics came to be construed as a site of fight or play for the unfettered attainment of egoistic goals, while power was viewed as a source of the obvious and unquestioned right to enjoy privileges. Jerzy Urban's ironic admonition not to worry about the government, because the government would easily feed themselves symptomatically encapsulated this experience and this philosophy of power.

This also entailed a vision of the politician as a ruthless opportunist motivated by the desire to gain privileges and by the will to command others. The politician was a morally ambivalent, double-faced and isolated player. Given this, common people should stay away from politics unless they wanted to join the by definition ruthless and immoral competition. The only solution was thus to develop a more or less duplicitous adaptive strategy and find a niche in which good life and the achievement of private, selfish interests were possible. The public sphere became an arena of uncertainty and distrust. One could only feel secure when surrounded by one's own "folk": family, friends and tested acquaintances.

In terms of social psychology, it basically meant the resumption of previous attitudes: a distrust of politics and the abandonment of the public sphere as a site of individual self-realisation and the civic culmination of human dignity. It seems that the crackdown on the Solidarity peaceable movement and the sociopolitical practice of the dark 1980s strengthened and exacerbated the philosophy of politics and power which had surfaced and been commonly endorsed in the Gierek era. Now, it became even more bitter, "darker" and more universal. 
The dissemination of this cynical interpretation of politics first of all produced an image of social life and of the public space in particular as a dangerous zone steeped in fight and competition, where everybody was chiefly, if not exclusively, motivated by egoistic interests and goals, revealed (by necessity) only in part. If one somehow landed there, one had to be alert and forgo trust. In fact, it was distrust, even the distrust of one's allies, that became the fundamental principle to rely on for success.

This bitter philosophy of politics was (and still is) coupled with ambivalent attitudes to the established, institutional social principles, including legal order and group loyalty. In a private game with the regime, one had skilfully to use the system's weaknesses, especially legal loopholes. Consequently, it was an expedient strategy to by-pass law and harness it in order to achieve one's immediate, situation-bound aims, which the communist regime eagerly did at every possible opportunity. The bitter social experience taught that the authorities and the political elite used rules as they pleased, bending and breaking their own laws as the need of the moment dictated. This even concerned the legal principles the regime itself considered especially relevant. This was aggravated by the belief in the importance of money as a tool to make holes in the apparently uniform system.

All in all, the attitude to law and institutional rules at the end of the communist era was specifically ambiguous: on the one hand, the "bad law" of the communist governments was reviled and an equitable democratic law was demanded, while, on the other, people were on a hunt for opportunities to circumvent or break law. This was the legacy Polish society had on the threshold of the transition.

\section{The Transition and the Original Sins of the Reborn Republic}

By default, the unexpected collapse of the People's Republic of Poland, when the PUWP - militarised as it was and yet incapable of governing - decided to share power with underground Solidarity as the representative of society, initially could not but bolster the former tendency described above, that is, the idealising vision of society and polity. All the more so as Poland's example quickly produced global effects. Of course, the communists believed they could retain domination in the new arrangement of forces. By their incapability to govern I mean the debacle of the martial law period as looked at through the lens of Ortega y Gasset's insistence on the relevance of public opinion to effective governance. Public opinion in Poland, even when hypocritically and opportunistically flattering the regime, never actually sided with General Jaruzelski. As Ortega concludes, citing Talleyrand, much can be done with bayonets except sitting on 
them, which means that, in the long run, it is impossible to govern without the support of public opinion. The generals' power was entirely negative, as they only proved effectual in issuing prohibitions and hunting down the shrinking group of underground oppositionists. Nothing else of the generals' plans could be implemented, even though a considerable part of society had certainly learned how to use the regime's operations for their own selfish purposes. The regime only governed negatively, unable even to elicit support for its right causes.

The victory of the dreamt-of democracy afforded the Poland-governing communists unprecedented success and emoluments, as it turns out in retrospect. This happened first and foremost because communism and the communist governments were never held to account and no moral symbol for new Poland was actually fashioned. This is the other "original sin" of the reborn Republic of Poland.

The "top-down" imposition of democracy and making the elites the leading, if not the only, power in the implementation of the socio-political reforms triggered growing frustration and discontent within considerable groups of society, not only among the workers who were made redundant overnight. The expectation that the mass participation of common citizens in state- and societybuilding processes would be promoted also proved entirely unrealistic. As a result, the only remaining participation forms were protests, street rallies and other manifestations: a spree of political happenings, including hunger strikes. Jan Kubik and Grzegorz Ekiert, American scholars of Polish descent, who interpret Solidarity in terms of citizenship, argue that the protest waves in the early 1990s were a channel of workers' (or employees') participation in democratic debate and democratic order-building. No other participation form - patently not the one they had expected - was available to them. ${ }^{187}$

The reason was that the quickly forming party system did not (and still does not) offer a real political representation of the interests and views of common citizens. It has always remained an elitist system. This does not result from society's

187 Grzegorz Ekiert and Jan Kubik, Rebellious Civil Society: Popular Protest and Democratic Consolidation in Poland, 1989-1993 (Ann Arbor: University of Michigan, 1999). Importantly, the findings of the 2010 study and of another, still continued study on the memory of Solidarity in local communities directly show that a considerable proportion of the respondents think that it was wrong to by-pass not so much consultations as real societal discussion on the systemic reforms. This implies that in the respondents' view the members of the Solidarity social movement and trade union deserved a "better" treatment from the emergent, post-1989 elite, had grown out of and was empowered by Solidarity. 
lack of knowledge about and ideas of democracy and its principles, which is what most sociologists argue in their studies of the socio-political transition. In fact, the basic principles of the democratic order, such as pluralism and the relevance of representation institutions, seem to have been commonly known and accepted, as found in studies conducted even under communism. Such findings were reported above all by Stefan Nowak. ${ }^{188}$ However, in the democratic ideal which Poles envisioned and endorsed back then, parties were underappreciated as chief organisers and advocates of social interests and values. If anything, this underestimation is even stronger today.

Similarly to Nowak, in a study we carried out in Mława and Szczecinek we asked our respondents to describe their ideal of a good political system. It turned out that the respondents' political views had an effect on their preferences for a more authoritative or, alternatively, a more open, participatory model of democracy (there were hardly any anti-democrats in our sample). However, even though many fundamental principles of modern democracy, such as the rule of law and the right of the opponents of the current system to express themselves, were cited by nearly all respondents (the proportions were in excess of $90 \%$ ), there was a symptomatic gap in their answers as support for a strong multi-party system was basically lacking. Only $44 \%$ of the respondents in Mława and 38\% in Szczecinek considered a multiparty arrangement to be a desirable feature of a good political system. We also found that membership in trade unions (of whatever type) rather positively impacted people's attitudes to parties, with the OPZZ ${ }^{189}$ trade-unionists proving most pro-party minded. ${ }^{190}$

These research findings are very vivid and consistent with Mirosława Grabowska's earlier thesis that Poles generally disliked political parties. Such sentiments are not very easy to explain, though I believe that the cynical vision of politics can be an important, if not decisive, factor in this aversion. The cynical vision of politics (and, consequently, of the political authority) was being consistently bolstered throughout the transition, especially that our purported

188 I refer here to the OBOP (Public Opinion Research Centre) study on "Przemiany społecznej struktury w świadomości społecznej” (“The transformations of social structure in social consciousness") (1965) and a later study carried out in Warsaw and Kielce (Ciagłość i zmiana tradycji kulturowej, ed. Stefan Nowak [Warszawa: PWN, 1989]).

189 OPZZ is the acronym for the Ogólnopolskie Porozumienie Związków Zawodowych (English: All-Poland Alliance of Trade Unions), a Polish federation of labour unions created in 1984. (translator's note)

190 Ireneusz Krzemiński, "Dobry ustrój a tworzący się ład społeczny," in Druga rewolucja. 
representatives - the representatives of society opposed to the party-state - now started to ignore public opinion and apparently had no intention to enact the good politician's role as defined in social consciousness in 1980-1981.

The fact that communism and the communist governments were not held to account only strengthened this vision of politics. Its philosophy of power was based on the PUWP's practice of governing. If the idea was now proclaimed that the regime of the People's Republic of Poland was not to be condemned, and even less so the deeds of individual Party dignitaries (including General Jaruzelski as the engineer of marital law), it should not come as a surprise that power, the state and social relationships were comprehended in such and not any other way. In this light, the cynical vision of politics was proving thoroughly founded.

This involved one more salient feature of Polish society in the transition period, namely a highly asocial attitude embraced by most Poles, both those well-educated and those low-educated. Again, sociological studies claim that our society is collectivist and, as such, harbours an excessive sense of entitlement. However, if we interpret the protests as a way of expressing and fighting for interests, and if we note people's general reluctance to set up or join institutions capable of securing these interests on a daily basis, the thesis of Poles' collectivism is rather untenable. Collectivism, at any rate, entails a readiness, if not an eagerness, to engage in organised and, nomen omen, collective forms of activity. Yet, if Poles collaborate, they do so only very briefly and in a one-off action (such as a strike or a road block), without any apparent inclination to turn this situation-bound bonding into a more permanent structure. Separate individuals are socialised only in protest and usually only for a while.

Polish society is rather permeated by a spirit of individualism, and the individualised isolation is only suspended for a brief negative mobilisation in defence of the jeopardised (above all individual) interests. This deficiency of socialisation is perfectly in tune with the vision of the world which was described as cynical above.

At the beginning, I suggested that the Catholic Church could also contribute to the dissipation of the democratic spirit of citizenship, especially in the early years of the transition. Paradoxically, citizenship attitudes include elements which the Church had powerfully commended in the resistance period, such as individuals' personal and subjective responsibility for their actions. As a community member, I have the right to speak out and act publicly according to my conscience and my understanding of the situation. Implicit in this idea is the belief that citizens are morally responsible and rely on their notions of good and evil or right and wrong. Also, as true believers, we must be guided in our daily lives by our moral judgment, confronting, discussing and negotiating it with 
others within the community. At any rate, debate within the Church is inspired by the Holy Spirit, as the Second Vatican Council documents eloquently insist.

However, in the early 1990s, the Church in Poland abandoned such a vision of the People of God and scrapped the notion of the community of believers in search of truth and good. Very quickly, a sharp division into priests and the faithful was demarcated, with the former defined as indisputable experts on faith and morality, and the former as docile followers. Triumphant ecclesiastical authoritarianism came to rule the day and claim mastery over individual and collective consciences as well as over the political sphere. In this context, the Church's fight for amending the abortion law was particularly consequential in its social effects. I do not question the Church's right to take a clear and radical position on the abortion law, what I argue, however, is that the form the Church chose for its campaign powerfully impacted the future socio-political developments. Tempting though it would be to refer to "debate" in this context, the term is hardly applicable, for though a debate on the abortion law indeed germinated in Poland, it was soon razed by ultra-aggressive attacks in which all views that differed from the Episcopate's very radical project were scathingly deprecated. I believe that the style of this first truly meaningful political skirmish formatively contributed to the rise and dissemination of a counterproductive and woeful style of public debate in Poland as such.

Of course, many more factors were involved in this desultory process, but this particular one was certainly consequential as the majority of public opinion, though quite welcoming of the Church's initiative, were far less restrictive than the Church on the permissibility of abortion. In fact, most people felt they were expressing their opinions in compliance with their Catholic credo and were fully entitled to do so as part of democratic debate, being at the same time prepared to change their views if persuaded by sound arguments. Regrettably, instead of arguments, they heard invectives and threats of retribution. The experience was a pragmatic lesson which taught people that their voice did not matter in the state and that the Church, previously the most reliable representative of society, had no intention to give ear to society anymore. Additionally, people of the Church haughtily and explicitly articulated anti-democratic notions, while a war against liberalism, i.e. against freedom as a systemic principle, became the major drive of Catholic thinking in Poland.

In this sense, what the Church did in the early 1990s can be seen as a factor both in undercutting the solidary, idealising image of politics and in bolstering the cynical image of the social world and the state. The after-effects of these developments still linger on, though it is equally important to notice that, over the recent years, the Church and its many organisations have begun to 
contribute to building and consolidating civil society in many regions of Poland, especially locally, in small self-governing communities. I mean mainly the many inherently citizenship-minded initiatives launched by religious orders (Jesuits and Dominicans) as well as the commitment of several parishes to the development of local media and social activism. Another precious, citizenship-related achievement of the Church is the development of charitable institutions, such as the Caritas.

\section{Sad Conclusion}

My answer to the questions posed at the beginning of this chapter focuses above all on the socio-political factors behind Poles' reluctance to commit to civic activities. As such, it certainly does not offer a complete picture, but in choosing this lens I was deeply convinced that the idea of politics, combined with people's social visions of and expectations towards the state order, provided the key to understanding this phenomenon. I addressed what I believed to be two fundamental representations of politics and polity, productive of particular individual attitudes. I referred to one of them as an idealising vision of the democratic state and to the other as a cynical picture of the social world. The course and the mode of Poland's socio-political transition have clearly tended to strengthen the cynical vision and to deprecate the idealising one. Concomitantly, the Solidarity experience has been devalued, while the lessons of martial law have been reinforced, attributing to force - i.e. to the violence- and money-based advantage - the decisive role in social relationships and in the exercise of power.

The elites also share popular consciousness, which has become profoundly anti-political and detractive of the political class and the political scene (as patently evidenced by the recent election results). The vices quite justifiably ascribed to politicians and politics can be viewed as the products of the same consciousness that spawns criticism. Yet this consciousness also underpins the behaviours of politicians, that is, of those citizens that dare enter the path of social career. As soon as they get involved in the political competition, the cynical vision of the social world makes them ruthlessly pursue their own and their group's interests. The paradox is that this vision of politics both produces anti-political critics and oppresses the practitioners of politics ...

The burgeoning of pernicious politics is, in my view, bound up with two "original sins" of Polish democracy. One of them was the fact that the democratic reformists - representatives of independent society as they were - entirely ignored people's expectations of the broad, institutionalised participation of common citizens in the new polity. Such expectations were indeed deep-running. 
They ensued from the project of democracy which had sprouted and been tested within the Solidarity unionist movement, a democracy project based on the broad participation of citizens in decision-making across all the community scales. Such expectations were overthrown by a new elitism of Poland's emergent democracy.

The other "original sin" was the lack of any symbolic, moral reckoning with the communist governments and the entire communist period in Poland as such. As a result, neither was the past symbolically assessed nor was a morally cogent symbol of Poland's new beginning put in place. This only re-asserted the practices and philosophy of Poland's communist regime, consequently lending credence to the cynical vision of the social world. This vision fuelled bad individualism and thwarted people's socialisation, a basic prerequisite of civil society.

Not holding communism to account also affected the formation of new, democratic institutions. Of course, the still persisting, old institutional relationships, uncontrolled in any way, easily influenced the newly emerging or transforming institutions. The effects of this process, dramatic ones indeed, can be witnessed now in the operations of institutions which are of ultimate relevance to the new socio-political order, such as education.

A few years ago, researchers of the Institute of Sociology, University of Warsaw, set out to establish whether and in how far schools promoted citizenship attitudes and democratic behaviours. ${ }^{191}$ Their findings were quite straightforward and rather depressing as far as initiating students into citizen roles was concerned. Antoni Sułek's study showed that at most schools students did not stand any chance to develop democratic behaviours, even though law made student boards mandatory at schools as the first form of democratic participation.

In Poland, student boards are hardly schools of democracy. For one, they are few and far between. And even if they are established and operate in one way or another, they are hardly ever treated by teachers and the administration as a real, institutional representation of students and a seminary of democratic behaviours, fostering the sense of democratic, civic responsibility. Another finding of the study was that rather few teachers believed it was the school's responsibility to prepare students for independent lives as citizens or to promote pro-democratic attitudes. The generation educated in the Third Republic of Poland does not resemble in the least the self-sacrificial, patriotic and clearly pro-democratic young people brought up by the Second Republic, which was

191 Krzysztof Koseła(Ed.), Młodzieższkolna orynku idemokracji (Warszawa: Wydawnictwo Oficyna Naukowa, 1998). 
beset by very serious problems with emergent democracy. In my view, the chaos in educational ideals and the disengagement of schools from citizenship education are largely attributable to the continuity between the People's Republic of Poland and the Third Republic.

Certainly, it cannot be the only factor. Family upbringing also shapes young citizens, as reported in my colleagues' older research and more recent studies. ${ }^{192}$ The studies conducted by Mirosława Grabowska and Tadeusz Szawiel show that, while market-related ideals and behaviours are commonly known and accepted, positive pro-democratic attitudes are only promoted in a very special set of families in which both parents have university education. The proportion of such families in the overall population is indeed negligible, but only in such families are children brought up as conscious citizens who appreciate the value of democracy.

I believe this outcome is linked to the triumph of the cynical philosophy of politics. This vision powerfully affects educational practices, both at school and within families. It fosters egoistic, competitive and asocial attitudes. As a result, young people, though vigorous, reasonable and tolerant of alterity and diversity of the human world, neither feel the need nor have the ability to collaborate with others, let alone having an inner impulse to act on others' behalf. Moreover, the studies cited above show that most young people have loving and caring parents, with whom they get on very well (though usually far better with mothers than with fathers), and feel neither need nor pressure to rebel. They are focused on their careers and invest a lot in social contacts with a circle of friends (a slight departure from the self-centred pattern). Actually, an interest in social issues and a dedication to collaboration with peers and people who do things for others are mainly displayed by young people with a deficit of familial warmth and parental intimacy. Young people's pro-social attitudes and behaviours seem to be largely dictated by an attempt to make up for insufficient family love. At homes dominated by devoted mothers, the young generation grow up into adults with no interest in active citizenship and no civic consciousness.

There are exceptions to this rule as every major political party has its own youth section or organisation, but more often than not membership in it is related to the choice of career rather than to the commitment to social ideals. The young party members are, apparently, just political professionals. Other

192 The young generation's non-citizenship attitudes were discussed by Paweł Śpiewak in Tygodnik Powszechny. 
activists are encountered in provincial communities, but they are so exceptional that nearly each of them is a conspicuously observable case...

The impact of the cynical vision of the social world is, indeed, impressive. The elimination of the citizenship component from education is clearly affected by the fact that mothers are the major pedagogical agency. The absence of fathers is spectacular in this context. No wonder that I called this part of the chapter "a sad conclusion." 


\section{The Republic of Hateful Enviers}

I guess I should first explain why this paper is included in this volume although it does not directly explore Solidarity as a social experience. What it does instead is showing how Solidarity - also as the original, conjoint experience and action has been used in politics in recent years in order to sow discord among Poles, a political discord which is rapidly mutating into an all-embracing, ideological discord. The ideological division is wrought mainly of national sentiments, which are strengthened by and enveloped in references to the past so much that their chauvinistic and megalomaniac investment deserves to be labelled as "nationalist." This text was originally written in 2006 and, regrettably, to make it mirror our current situation more accurately, some of its vocabulary should be intensified. The point is that political actions are now fuelled not simply by envy, but by political, ideological and also personal hatred. In these actions, the Trade Union Solidarity, which still exists (though considerably weakened by its political engagement), is drawn into the mire of envy and hatred. Today, the operations of this trade union are, literally, the polar opposite of the activities of the "first" Solidarity. Addressing such concerns, this chapter also attempts to understand what has happened with and to the legacy of the "first" Solidarity in the realities of democratic Poland.

\section{Changes in the Language of Public Debate}

The situation in Poland has become unbearable. At moments, I have a feeling (which I expect is shared by many people) that we have found ourselves in a world strangely resembling the People's Republic of Poland in many respects. It is hard to explain how we again wound up all padded up in the propagandist "cotton wool," as the PUWP's verbiage was commonly referred to in the Gierek era. The only difference is that the verbiage is now very strongly anticommunistically coloured; yet though its colouring has changed, its structure has mostly remained the same.

Certainly, some of the right-wing commentators who repeat that public discourse has changed decisively, if not dramatically, are right. The term "public discourse" as such is rather vague, and when using it I have a few issues in mind. Firstly, I mean that the conceptual and ideological categories used to define the situation and the identities of political actors have changed. They actually form a framework of particular positions and views. Secondly, I mean that what is 
admissible in public statements (language, formulations, expressions and the wording of assessments and descriptions of situations) has changed. Thirdly, and this is where the similarity to the communist period is at its strongest, everything has become politics, politics understood rather narrowly as support for or criticism of the government in place, i.e. the current political authority. The split into the governing coalition and the opposition has reached its zenith in a public split. The division is deeper than disagreements in the wake of the first election victory of the post-communists in 1993.

To paint a full picture, we should additionally consider emotions, both manifest in and induced by public articulations. Public discourse in Poland is now strikingly aggressive, confrontational and infested with unconcealed malice and evil intents. Admittedly, observers and commentators have noticed and denounced such features since the onset of democratic Poland, accusing political actors of hostility and deprecatory name-calling in public debate, in which adversaries have usually been approached as rivals. In my analysis of the language of the first democratic election campaign, I pointed to the personalisation of discourse,${ }^{193}$ an idea picked up later by other scholars. ${ }^{194}$ My point was that instead of naming and expressing differences in a language of ideas or problems, political actors chose to launch personal attacks on their opponents. Always morally suspect, if not downright vicious, political adversaries were branded and humiliated for thinking differently and espousing different goals. This set the tone of public dispute in Poland, in which deprecating charges intended to demolish the opponents' social and political reputation came to replace arguments and rational evaluations. Sociologists have attempted to describe this process in a variety of frameworks. They have talked, for example, of debate mutating into a monologue-based performance or of a ritual chaos as people who spoke in public had no intention to negotiate anything, least of all a shared position, and all they wanted was to say what they had planned to say in order to grind down their opponents. ${ }^{195}$

If we had a systematic account of how public discourse was evolving in Poland over the transition period, it would likely show that such "discussion" modes had

193 Cf. Ireneusz Krzemiński, “Wybrać lepszy świat,” in Mirosława Grabowska and Ireneusz Krzemiński, Bitwa o Belweder (Kraków and Warszawa: Wydawnictwo Literackie "Myśl,“1991).

194 Jadwiga Puzynina (Ed.), Etyka międzyludzkiej komunikacji (Warszawa: Wydawnictwo Naukowe Semper, 1993).

195 Cf. Marek Czyżewski, Sergiusz Kowalski and Andrzej Piotrowski, Rytualny chaos. Studium dyskursu publicznego (Kraków: Aureus, 1997). 
systematically been encroaching on the public scene and we were now in the final stages of this "developmental" process. The process in fact seems unstoppable; if a right-wing commentator who is lionised by his supporters as a modern literary classic writes that a "monkey reason" is taking the upper hand among other commentators and the Polish intelligentsia as such, the people he targets cannot reasonably be expected not to repay in kind.

Abuses and accusations have become a common fixture in what political actors say about their political or discursive opponents. It is a kind of "whacking," as the "whackers" themselves have called it. The "monologic performance stage" of political discourse has changed into a boxing ring where discussing is reminiscent of prize-fighting, well, of kick-boxing rather as the rules of engagement are rather scanty. To lash out with accusations first, before any arguments are even voiced, and then to present the adversary's position in the light thereof has long been the method used by the Radio Maryja and Nasz Dziennik. ${ }^{196}$ This discussion method has now become a "standard" method, widely applied by the $\mathrm{LaO}$ $(\mathrm{PiS})^{197}$ politicians and supporters. The political discourse scene is an arena of fight, a political battlefield. As a result, no genuine discussion is in fact possible, whatever the topic. Instead, verbal - or, as they are dubbed now, media - duels are the only available option. Right or wrong, but after all underpinned by a reasoning, the views voiced by the adversaries are discredited at the start, and their advocates are immediately defined as strangers and enemies whose viewpoint cannot possibly be endorsed. The "if you're not with us, you're against us" logic rules the day, and the world is divided into beloved allies and bitter enemies. This discussion mode has been displayed for a while now by philosopher Legutko, ${ }^{198}$ a $\mathrm{LaO}$ senator, not to mention Zdzisław Krasnodębski, ${ }^{199}$ who was my close colleague not so long ago. I will not use any epithets in order to resist the reciprocation mechanism mentioned above. But this introduction attests to siding with a certain "camp" anyway ...

196 The Radio Maryja is a Torun-based Polish Catholic broadcaster of explicit right-wing and nationalistic leanings. Nasz Dziennik (English: Our Daily) is a daily newspaper of a very similar slant. (translator's note)

197 PiS stands for the Prawo i Sprawiedliwość (English: Law and Order; LaO), a conservative and nationalistically inclined right-wing party in Poland. (translator's note)

198 Ryszard Legutko, Professor of Philosophy at the Jagiellonian University in Cracow, who was elected to a seat in the Polish Senate in 2005. (translator's note)

199 Zdzisław Krasnodębski is a Polish sociologist and social philosopher. Affiliated for many years with the University of Warsaw, he was appointed Professor at the University of Bremen in 1995. (translator's note) 
Importantly, discourse as warfare is strongly redolent of communist newspeak. Under the People's Republic of Poland, the public language was inseparable from the propaganda, which framed all events in terms of struggles and military campaigns, starting from "fighting winter" and ending with "the battle of harvest." The diction of strife and combat was used with heightened intensity to describe social developments and to address or depict the actual and potential critics and opponents of the system. Such language was, of course, emotionally charged, but in time everybody got used to the aggressive convention so much that it became transparent: it became, indeed, a convention. As part of this convention, its martial metaphors were given a deeply moralist twist. Deprecation of and contempt for the opponents also became conventionalised. Thus, in all probability, our current difficulty with fashioning a sharp, yet rational and civil discourse is also part of the legacy of the communist past, a bequest which at least some of us resent. Yet this kind of discourse is today forcefully promoted by $\mathrm{LaO}$ politicians, who are government officials and, as such, trend-setters.

Admittedly, their opponents in public discourse - people who have been showered with scurrilous names, from "lying elites" (Polish: tże-elity) to "clever clogs" (Polish: wykształciuchy) - "lose it" from time to time and go into hysterics. When a scholar of my acquaintance phones me up, sobbing that Poland is now like Germany after the Nazis' election victory, I tell her she is exaggerating and advise her to calm down.

And yet the analogies between the socio-political process at hand in Poland and the interwar developments cannot be purely figmental if Jadwiga Staniszkis ${ }^{200}$ resorts to such a comparison. She has compared our current situation with the events in the Weimer Republic. I guess she knows what she is saying because, at any rate, it was her politicised account of the social situation in the Third Republic of Poland that became the basis for the LaO's unfolding revolution, a revolution dubbed conservative by kind-minded people.

Vilifying post-communism mingled with neo-liberalism (practically called libertinism), conservatism is to serve as an honourable ideological banner and a slogan of the political "reform" of the state. In practice, the reform represents nothing other than the appropriation of the state by the $\mathrm{LaO}$ and the governing coalition. The axis of this conservatism is the idea of a moral reckoning with the founders of the Third Republic and the so-called elites. The point is that whoever has had any say in the public discursive space is counted among these elites

200 Jadwiga Staniszkis is a Polish sociologists and political scientists. For many years, she was Professor at the University of Warsaw. (translator's note) 
unless they have been quick enough to join the only right camp. The moral reckoning is founded on two pillars; one of them is the assessment of the sociopolitical reality, and the other is the moral evaluation of the new order. It was Jadwiga Staniszkis's sociological vision (which Professor Zybertowicz ${ }^{201}$ augmented with the idea that the transition was plotted by the secret services) that effectively helped justify the imperative to hold the Third Republic to account and to heal (i.e. repair) the polity.

But there is more to the moral project than just that. In fact, the reformists are out to battle social diversity in the name of limiting the rights and public presence of various minorities. Gays and lesbians, along feminists, have explicitly become arch-enemies. The reason for this is that the demands of moral salubrity in public life have nearly always drawn on the social teaching of the Catholic Church. Treated as the chief directive, this teaching is supposed to guide not only morality but also political action. Since the election campaign, faith and religion have been instrumentalised and Catholicism thoroughly ideologised in the service of political struggle. It is hardly a secret, and the political union of the state and the Church has long gone beyond the government's alliance with the Radio Maryja. There is even a brilliant bard at hand, eager to argue that Father Rydzyk's ${ }^{202}$ radio has undergone a deep "civilisational" change, eradicating and even denouncing anti-Semitism. Unsurprisingly, the publicist, whose career seems to be spiralling, demands that the former charges against the Torun broadcaster be dropped and forgotten altogether. ${ }^{203}$ That's what you call the momentum, indeed!

How can we convey the situation in less partisan terms, suppressing the emotions, difficult thought it admittedly is, in order to analyse them, rather than to succumb to them?

\section{Political Divisions and Social Divisions}

One issue to examine is the ideological underpinning of the way the $\mathrm{LaO}$ and its leaders think. This is all the more relevant as in the 2006 electoral campaign, the ideological agendas of the $\mathrm{LaO}$ and the $\mathrm{CP}(\mathrm{PO})^{204}$ - the ideological and moral

201 Andrzej Zybertowicz is a Polish sociologist and publicist. Affiliated with the Nicolaus Copernicus University of Toruń, he has served in several public capacities. (translator's note)

202 Father Tadeusz Rydzyk is the Director of the Radio Maryja. (translator's note)

203 Tomasz P. Terlikowski, “Cywilizowanie Radia Maryja,” Dziennik, 8 Sept.2006, p. 26.

204 PO is the acronym for the Platforma Obywatelska (English: Civic Platform, CP), Poland's major centrist party. (translator's note) 
competitors on our political scene as they are - allegedly converged to some extent. The political scene had itself undergone an unexpected re-modelling, which questioned the idea of the post-communist division. ${ }^{205}$ The postcommunists were pushed to the margin, and the "pact" they had previously contributed to creating became the major target of the onslaught of the victorious party (i.e. $\mathrm{LaO}$ ). The "pact" meant a collaboration of the oligarchic business and political circles that impacted operations of the state. Importantly, to eliminate the "pact" was a shared goal of the post-Solidarity groupings, as both the $\mathrm{LaO}$ and the $\mathrm{CP}$ considered a thorough reform of the state an absolute necessity.

However, even back then, their visions of the reform were discernibly different although both the parties wanted, for example, to amend the lustration bill. The lustration bill was perhaps the most obvious convergence point of the agendas of the parties, especially as exemplified in MP Rokita's ${ }^{206}$ vocal demands in this respect. To have the communist secret police and security archives unclassified without exceptions was vigorously demanded by both Rokita and the Kaczyński brothers. ${ }^{207}$ Despite this, the two parties also differed on this point even before their electoral hiatus. For the Kaczyński brothers and the $\mathrm{LaO}$, the reckoning with communism and the removal of everybody who had collaborated with the former regime from public life were a priority, if not the priority. The $\mathrm{LaO}$ also demanded action in the judiciary in this respect and painted it in very radical colours. As far as I remember, the $\mathrm{CP}$ agenda did not include such proposals, even though overlapping with the LaO's position on the most important point, i.e. on depoliticising law enforcement and the police, combined with strengthening the judiciary autonomy.

Having (marginally) won the election, the $\mathrm{LaO}$ made the reckoning into their absolutely fundamental strategy. For this purpose, the $\mathrm{LaO}$ sacrificed quite a lot, including the trust and support of a major part of the intelligentsia, or the "lying elites" as the party dubbed them. The goal turned out to be so central that to achieve it, the $\mathrm{LaO}$ did not shrink from discrediting all independent opinionmaking elites, alongside the independent agencies of the distributed and differentiated state power. At the same time, the political division was framed as

205 Mirosława Grabowska, Podział postkomunistyczny. Społeczne podstawy polityki w Polsce po 1989 r. (Warszawa: Scholar, 2004). My review of this book, which won the Reverend Józef Tischner Award conferred by Znak in 2005, was published in Przegląd Polityczny 73/74, 2005.

206 Jan Maria Rokita, one of the leading CP activists and an engaged poset (Member of Parliament). (translator's note)

207 Jarosław and Lech Kaczyński, prominent leaders of the LaO. (translator's note) 
a social division into the elites (beneficiaries of the transition) and "common" Poles, a nation that had so far been grossly abused and cheated by the government colluding with the Third Republic's elites. To this purpose, the shared and unifying legacy of Solidarity was fragmented into the solidary investment and the liberal preoccupation as if the liberal pursuit of freedom had not inspired all the members of the movement. Like religion, the social mythology of Solidarity was used to bolster the political position of the party.

To achieve that, a language has been mobilised which reminds many people of the year $1968 .{ }^{208}$ Though not targeting Jews or Zionists this time, the language describes reality in a similar fashion and triggers similar emotions. The ubiquitous "pact," indefatigably combated by the $\mathrm{LaO}$ politicians, functions like the Zionists did in 1968, for the narrative has it that under the cover of democracy "they" (politicians, in particular post-communists, and the elites of the Third Republic) have grown rich by robbing the people - the common citizens - in a variety of ways, e.g. by appropriating the revenues from privatisation. This inevitably involved betraying the nation and allying with foreign forces. The antiintelligentsia subtext of this new social division conveniently tunes in with an unarticulated but essential class distinction: the Third Republic's politicians and elites are the class of the rich opposed to the poor people - the nation - who have been left to fend for themselves. ${ }^{209}$ The term "elite," polyvalent as it is and referring to various kinds of elites, has been manipulated into representing a politically coloured whole in which the elite is synonymous with the intelligentsia.

Another similarity with the March "68 rhetoric is that the "winners" of the transition period are in various manners framed as "strangers" or "foreigners," who are not fully and not really "our folk." The class-inflected division is thus paired with a nation-slanted division. The latter involves associations with the communist past (dependence on and servility to Moscow) and with the present-day relationships with the West (connections and subordination to the foreign capital, predominantly German, but undoubtedly also Jewish).

Such a model of social thinking is quite widespread. In my 2002 study on anti-Semitism, over $38 \%$ of the respondents stated that there were a lot of politicians of Jewish descent in Poland. No wonder they would "support their people..."

208 For a discussion of the similarities between the current language and the March'68 rhetoric, see Paweł Śpiewak, "Nie moja IV Rzeczpospolita," Dziennik, 14 Sept. 2006.

209 This is well illustrated by Andrzej Lepper's defence of the parliamentary Investigation Committee for the Privatisation of Banks, in which he denounced Chairman Kot's salary as outrageous (TVN 24, September 2006). 
Moreover, in comparison with the 1992 data, unwillingness to have Jewish entrepreneurs in Poland considerably increased: while in 1992 their presence in Poland was supported by almost $40 \%$ and bewailed by $45 \%$ of the respondents, in 2002 the proportions were, respectively, less than $25 \%$ and $61 \%$ of the sample. Similar findings concern all kinds of Jewish presence in Poland. Importantly, over the same period, the positive attitude to the presence of German entrepreneurs hardly changed (41\% in 1992 and 42\% in 2002), while the negative attitude to it picked up from $42 \%$ in 1992 to $50 \%$ in 2002. I will return to these data later.

I believe that the popular-national strand is fundamental to Jarosław Kaczyński's political - and probably ideological - strategy. The LaO's alliance with the Radio Maryja and with the social forces that support Father Rydzyk's broadcaster "at the bottom" and "at the top" (especially at the top of the Church hierarchy) is probably something more than just a matter of electoral and parliamentary tactics. This is a deliberate alliance which, in all likelihood, best expresses the $\mathrm{LaO}$ leader's ideological orientation and his intellectual project. In my view, this means building on and reviving Poland's political tradition of Endecja (National Democracy; ND ${ }^{210}$ ), which is strongly indicated by the attempts to transform the state and by the changes in the rhetoric and language of public debate outlined above.

Sharply delineated in public speeches by the $\mathrm{LaO}$ leaders, the division between the people-nation and the intellectual elite comprises the pitting of the national tradition against liberal Europe as one of the key contrast. The distinction is quite capacious and by no means unambiguous. Still, I believe it is crystal clear that the $\mathrm{LaO}$ and its leaders champion the idea of the state which is morally rooted in and morally underpinned by the national tradition and the national mentality. Crucially, this mentality is identified with Catholicism. As a consequence, the state cannot possibly be morally indifferent; on the contrary, the state and its institutions are obligated to ensure that society act morally and, thus, to demand that citizens honour national values. The state's legislation should also be subordinated to the moral tradition. What results from this combination is a model of national democracy in which the central, authoritarian state power has a crucial role to play. The planned and implemented changes in the legislation lead us towards a state that restrains socio-political pluralism and institutionally

210 The Narodowa Demokracja (English: National Democracy), called Endecja (from the ND acronym), was a Polish political movement developing from the second half of the $19^{\text {th }}$ century. Originally patriotically committed, the movement grew clearly right-wing and nationalistic, with its radicalism peaking in the interwar period. (translator's note) 
exercises moral control over social life. This entails severe limitations on the local self-government system by making its bodies a party-based and party-oriented element of the nationwide political structure. In such a state, the democratic and liberal pursuits are without a doubt severely undercut.

\section{The Catholic-National Socio-Political Unity}

The mutations of the debate result from re-appraising and re-casting the vision of a democratic polity. In the new version, the state can be democratic if it is based on the national tradition, national values and national identification. As such, this species of democracy is circumscribed and defined by the national and Catholic principles. Unsurprisingly, there is no room for gays and lesbians in this model, with feminists and even atheists falling outside it as well. The "morally healthy" nation is contrasted with the intelligentsia, who are in league with "strangers" and succumb to demoralised, atheistic Europe.

This contrast has not only a political function but also an essential - both dividing and unifying - role. Shaped as it is now, the discourse and political actions of the election winners very incisively rupture society by framing and highlighting the differences and divisions addressed above. At the same time, this politics of division integrates all those who side with the government and evokes a "dream of unity."

No matter how multifarious the original Solidarity was internally, the overwhelming impression of unity for which it stood dominated the collective memory. In the wake of the anti-communist breakthrough and the birth of the new, democratic Poland, the reformists failed to produce and consolidate a clear symbol of Poland's social unity. An idea of what founded the shared, democratic values, to respect which was central to any democratic polity, had not yet taken shape in social consciousness when divisions quite naturally started to proliferate, and the once uniform movement changed into a tangled mesh of mutually warring groupings before it even had an opportunity to be fully revived. The idea of political unity was deeply coveted by common people all the way; in fact, the famous "war at the top" disrupted the democratic process so profoundly just because it totally contradicted the social expectations. Additionally, the conflict, as mentioned before, was enveloped in such a drastic atmosphere that it effectively put many people off political participation. Subsequently, the victory of the Solidarity Electoral Action (AWS) ${ }^{211}$ in the 1997 election was undoubtedly a

211 AWS stands for the Akcja Wyborcza Solidarność (English: Solidarity Electoral Action), which was a coalition of political parties formed in 1996. 
result of re-kindling the hopes for unity - a revival of the "dream of civic community" - which, as we know, ended in a dismal fiasco.

Disappointing or not, the event was an important lesson for (at least a considerable group of) voters, as they saw that political unity was a misguided expectation in democracy. Yet, it also served as a strong consolidating impulse for a radical minority, who tended to blame the failure of the political unity project on the presence of "strangers" and "enemies." This produced an embryonic form of a mentality that was to burgeon in the late 1990s and to call for reviving the "truly" national community, expressed in and governed by a "truly" national state. In the period, major decisions were being made about Poland's accession to the European Union, providing a backdrop against which the radical, national positions were emphatically articulated. As those who connived with the "foreigners" against the "common" Poles became tangibly real, their presence and actions could be pointed to as a "unifactorial" explanation of unfulfilled dreams and expectations and as a cause of all injustice, including individual failures in the new socio-economic order. This social process, which cannot be equated either with thinking about or with experiencing reality, but involves both of them to a degree, was taken advantage of by the $\mathrm{LaO}$.

Hence, what I argue is simply that the layers of the mentality which more or less abundantly, but always clearly, draws on the legacy of the pre-war national and Catholic movement form the ideological fulcrum of and the real "spirit" infusing the practices of the governing coalition of the $\mathrm{LaO}$, the Self-Defence and the League of Polish Families. The evocations of this tradition may not be fully conscious. At any rate, only a small group of Poles are really familiar with this tradition, yet the group is significant. The tradition was revived as an intellectual legacy as early as in the 1990s by some Catholic circles (led by a group of professors of the Catholic University of Lublin) and a portion of the Catholic clergy. I believe, the tradition was also alive among academic historians.

This anti-liberal tide, anachronistically conceived as it was, did not ensue from reflection on the present situation in the West and worldwide but flowed uninterruptedly from the past. Swelling up of old (and certainly from the mid-1990s on), Polish anti-liberalism has been very closely associated with the national and anti-European sentiments, manifest in what has come to be called Euroscepticism. The national tradition was contrasted with democratic and capitalist Europe, which was painted as atheistic and morally dissolute. The national tradition was simultaneously set against all those who, purportedly allied with the post-communists and profiting from the capitalist transition, sought Poland's "merger" with Europe. One of this tradition's past chief indicators and integral elements, anti-Semitism today avails itself of the cluster of $\dot{z} y d o k o m u n a$ 
(Judeo-Communism). In this framework, the Jew symbolises the "other" and the "enemy," alongside with the German, a significant symbol that has been extended to cover the entire liberal and united Europe. This mentality accommodates all political and media events, from "a Wehrmacht grandfather" 212 to the bashing of Balcerowicz.

\section{The Mentality of Religious Repression}

This mentality showed in my research findings on anti-Semitism and national stereotypes. As mentioned above, the first survey was conducted in 1992 and then repeated, with all necessary updates, in 2002, i.e. long before the 2006 general election. These data overlap with the assessment in which Jarosław Kaczyński, the chief founder of the $\mathrm{LaO}$, grounded his political project. Clearly, the Kaczynski brothers realised what kind of mindset was on the rise and what political opportunities it offered.

The dynamics of empirically observable mental changes were surprising, indeed. First, the proportion of anti-Semitic attitudes markedly increased, but at the same time an equally pronounced division appeared between the respondents who declared anti-Semitic sentiments and those who rejected them. The proportion of undecided or wavering respondents became negligible. The division was later replicated in other data: Poles split into those embracing anti-Jewish, anti-Semitic attitudes and those repudiating them, far more decisively than ever before.

Responses to these findings were also telling. I remember that in an Internet chat following a TOK FM broadcast in which I had reported the survey results, an internaut called me "an idiot of a professor who believes in anti-Semitic attitudes, whatever they might mean." Of course, that response first made me furious, but if it is interpreted (together with other similar reactions expressed, in particular, by young people) as epitomising a certain attitude, it deserves to be taken seriously. Namely, it may suggest that no matter how widespread anti-Jewish sentiments are in Poland today, there are social groups where such attitudes do not occur at all and their members think of such attitudes as being "from another planet." Apparently, they have no contact with mindsets that engender and sustain such attitudes. If it is indeed the case, the mental and moral divisions among Poles are

212 An argument that his grandfather had served in the Wehrmacht was used to discredit one of the presidential candidates in the 2005 election by a politician from a competing party. (translator's note) 
profound and significant. The polarisation thesis seems to be well corroborated by data from everyday life.

Secondly, xenophobic attitudes are on the rise, if xenophobia is understood as a generalised distrust of and an aversion to national, ethnic and racial others. One of the items in our survey concerned the dislike of various minority groups. The specified group identities included Germans, Russians, Ukrainians, Arabs and Africans. It turned out that a dislike of one of them was associated with a dislike of the others. While such attitudes were not recorded in 1992, today xenophobes in the strict sense of the term accounted for over $10 \%$ of the sample.

Thirdly, to my surprise, an unexpected profile of religiosity was found. Totally unlike in 1992, religiosity - measured both as the declaration of an inner attitude (fervent believer, believer, undecided, non-believer) and as religious practice very pointedly promoted not only anti-Semitism, but also all condemnation and rejection of other minority groups. Our survey questions included eighteen minority group-identities, from an ex-communist, to a homosexual, an inactive unemployed person, a prostitute, a Roma, an Arab and an African, to a feminist, i.e. a woman who fights for her rights. ${ }^{213}$ In all - emphatically all - these cases, the respondents who declared deep faith and regular church-going, reported more dislike of and were more inclined to reject these outgroups than other respondents. This implied a clear model of repressive religiosity, in which moralism served to brand, punish and exclude. Needless to say, the declared religiosity and the high frequency of religious practices were coupled with the reported anti-Semitic attitudes. This was indeed surprising as the finding starkly differed from the 1992 data, where the declared deep faith promoted less exclusionary attitudes to "others," a position, so to speak, more sympathetic towards minorities and "freaks." The early $21^{\text {st }}$ century brought us a new species of religiosity, one prompt to stigmatise and reject; briefly speaking: a repressive religiosity. This proves that the experience and manifestation of faith considerably transformed within Polish Catholicism.

That's not all. Such a restrictive religiosity could not be ascribed unambiguously to one, defined social category, such as, for example, the uneducated or the rural population. Of course, less educated people and residents of villages and small towns reported such mindsets more frequently, but the education factor

213 For the relevant data, see Ireneusz Krzemiński, Antysemityzm w Polsce i na Ukrainie. Raport $z$ badań (Warszawa: Wydawnictwo Naukowe Scholar, 2004), in particular the Chapter entitled "Postawy antysemickie po 10 latach," pp. 56-57, and Tables on pp. 58-60. 
was by no means univocal. Educated believers also reported such attitudes. In contrast, commenting on the 1992 findings, I outlined two models of faith i.e. the religiosity of the educated vs. that of the uneducated - as significantly differing. ${ }^{214}$

Now, the data indicated an opposite image as an educated and religiously committed group had appeared who fully accepted and expressed attitudes which sociologists as a rule attribute to poorly educated people in the lower strata of society. This likely implies another division, i.e. a split within the intelligentsia caused by differences in the very basic hierarchy of values. The varying experience of faith and the self-perception of one's own religiosity would be important factors in and signs of these differences. Apparently, the attitudes are also (getting) polarised within the intelligentsia. The emergence of educated, religious anti-Semites and enemies of alterity would corroborate the idea of the return of old ideological worldviews, at least of the nationalist-Catholic ideological bias. I believe that this hypothesis is fully justified, given the political practices of the $\mathrm{LaO}$ coalition, its young ministers and state functionaries, whose cradle was the All-Polish Youth (Młodzież Wszechpolska). ${ }^{215}$

\section{Hateful Envy and Anti-Democratic Authoritarianism}

Thus socio-class and socio-national divisions are coupled with the politically meaningful moral divisions between different value systems. To put it briefly, since the 1940s, social-psychological and sociological research has studied the types of consciousness that support democracy or thwart it by turning towards a totalitarian - or at least an authoritarian - style of governance. The mentality I am discussing here can certainly be described as authoritarian consciousness.

The notion of authoritarianism had a momentous role to play in the history of sociology and social sciences in the $2^{\text {nd }}$ half of the $20^{\text {th }}$ century. As it were, the concepts of the authoritarian personality and the totalitarian order served to explain Nazism, Fascism and Bolshevik communism (even though belatedly and with some reluctance). Erich Fromm's Escape from Freedom, which was only published in Poland at the threshold of the Gierek era, presented one version of this concept. The concept was explicated in a more scholarly way, based on

214 Cf. Ireneusz Krzemiński (Ed.), Czy Polacy sq antysemitami? Wyniki socjologicznego badania (Warszawa: Oficyna Naukowa, 1996).

215 A Polish youth organisation embracing the Catholic doctrine and nationalistic standpoints, affiliated with the League of Polish Families (Liga Polskich Rodzin), an ultraconservative party. (translator's note) 
empirical field research, in the volume The Authoritarian Personality, which stirred enormous interest and considerably affected social thinking and research, inviting at the same time fervent criticism. The criticism concerned both the very notion of the authoritarian personality, which seemed to describe the "modern" devil, as well as the empirical ways of studying attitudes and mental objects. As a result of this criticism, new concepts were developed. One of them was the theory of "open" and "closed" minds and Rokeach's concept of "pro-democratic" and "anti-democratic" mindsets, which re-worked the original concept of authoritarianism.

The idea that there are mentality types which foster adaptation to democratic societies and those better suited to an ordered world managed by authorities continues to be an important factor in sociological knowledge. In Poland, scholars such as Bogdan W. Mach wanted to see how authoritarian-minded people coped with the new realities and whether mental openness and flexibility promoted success in democratic Poland. ${ }^{216}$ The findings from the early transition period, analysing which took a few years, ${ }^{217}$ were indeed very interesting, albeit little known. Consistently with sociological knowledge, the data showed that mentally flexible and open-minded people coped well with the changing world, even if they found themselves in adverse situations. Yet the data also indicated that authoritarian people did not cope worse, especially if they had retained bonds with authoritarian families. What interests me most is that, in the 1990s, the authoritarianism of workers decreased considerably as if the new demands convinced them that flexibility, mobility, knowledge and openness to the world should promote success. At the same time, the level of authoritarianism among the intelligentsia did not change significantly as if democratic freedom of action and the new rules of life did not matter much in terms of coping with reality. Mach explains this finding by positing that the intelligentsia had earlier had good reason to feel a greater social fear and anxieties in relation to the sociopolitical transformations. Since educated people had been more aware of the possible difficulties and risks of the transition, their anxiety could "conserve" the levels of authoritarian attitudes and orientations among them.

216 Bogdan W. Mach, Transformacja ustrojowa a mentalne dziedzictwo socjalizmu (Warszawa: ISP PAN, 1998).

217 Bogdan Mach's research was a rare example of panel studies as the researcher surveyed again the same sample of respondents whom he had originally studied towards the end of the communist period in Poland. 
While it may be an informed explanation, the data briefly discussed above encourage another thesis: the intelligentsia's authoritarianism was strengthened, because a considerable part of the intelligentsia adopted ideologies that justified the value and applicability of authoritarian notions and attitudes. Based on the Catholic and national tradition, Polish conservatism exemplifies an ideology that justifies authoritarianism as a mental and psychological orientation. The religious identification of some intelligentsia clearly pushed them to adopt the tradition of the National Democracy as embodying conservatism and anti-communism.

As already mentioned, studying authoritarian attitudes is a challenge. The authoritarian attitude includes an inclination to punish severely, assess rigidly, hold an ideologically clear-cut (black-and-white) world-picture and, as emphasised by all researchers, have a very simple take on child-raising. The latter is a very good predictor of the authoritarian attitude. ${ }^{218}$ Our surveys included an item asking whether children should be brought up to be obedient or to think independently. Obedience was chosen by almost one fifth (about 20\%) of our respondents. It represented a minority of the sample, but it was certainly a significant minority. The study confirmed that the authoritarian orientation produces a strict form of the mentality discussed above. The mindset including anti-Semitism, xenophobia and a dislike of all "freaks," combined with strong religious loyalties and the affirmation of the nation, represents the authoritarian attitude to the world. It is not a coincidence that people who embrace such attitudes are, at the same time, the listeners of Radio Maryja. Thus the notion that the Radio has undergone an ideological transformation is rather ill-informed: in fact, the type of religiosity represented and propagated by the Radio is certainly not indifferent to general ideological, social and political orientations. The Radio also inculcates authoritarian attitudes in the listeners.

This authoritarian mentality, nurtured by the nationalist and Catholic tradition, is undoubtedly fuelled by resentment or, as it is put in Poland, by envy. This mentality absolutely identifies itself with its own national group as the champion of the only true values, in defence of which it blasts all those who think differently. This mentality divides the world into "our folk," who are devoted to the nation and united by collective, strong leadership, and the strangers, who must be removed from sight or excluded from society. Prototypically, this mentality

218 This is also reported by Mach as well as by Jadwiga Koralewicz, who first studied authoritarianism in Polish society in the 1970s. See Jadwiga Koralewicz, Autorytaryzm, lęk, konformizm: analiza społeczeństwa polskiego końca lat siedemdziesiątych (Wrocław: Ossolineum, 1987). 
found its major enemy in Jews, who - diffused across the group as they were had to be branded and isolated somehow (including, as we know, the idea to send them all off to Madagascar...). Now, the enemy has changed, and the role of Jews as enemies of the Catholic morality in Poland has been taken over by gays and lesbians. Still, the political arch-enemy of national Catholicism is the liberal, synonymous with an atheist, a capitalist voluntarist and a hedonist rolled into one. The anti-minority answers in our survey contained one more telling element, namely a set of attitudes analogous to xenophobia, which I called the religious political correctness factor. The respondents who expressed reluctance to acquaint an abortion-allowing person at the same time disliked atheists, feminists, members of parties whose agendas they didn't endorse [sic!], the passive unemployed, ex-communists and alcoholics (though the last item had a lower factor "loading"). This is a very revealing "cluster" of dislike attitudes. It adds up to a whole which aggregates hostile views identified and attributed by the respondents. This produces an impression of a right-wing, Catholic political correctness, which surfaces in Polish journalism and Polish politics. Interestingly, the dislike of members of the parties whose agendas one does not endorse ranks very high on the scale of social aversion. ${ }^{219}$ Clearly, the anti-liberal orientation shows here as well.

Inferably, the authoritarian, nationalist-Catholic mentality has its social and political expression. It generates a particular image of the social world in which the national substance encounters foreign elements - those who are not, or are only ostensibly, "our folk" - that must be identified and labelled to prevent them from harming the nation. Of course, this is a projection of self-experienced hostility, as is the case in the classic model of anti-Semitism in which hostility one experiences is justified by features and actions attributed to Jews. The enemies are produced in a certain way in order to confirm their evil features and intents. It has an important implication that points to the particular role of Polish anti-Semitism, which is, as a matter of fact, more of a symbol of the national mentality than an actively hostile attitude to real Jews! The liberal - let alone the gay and the lesbian - is actually something and somebody far more real and palpable.

To finish with, one more feature of this mentality must be named, especially when it serves as the basis of social and political action. This feature is our eponymous envy, which appropriates the right to attack enemies who treacherously

219 Thirty-eight percent of the respondents reported the dislike of the members of parties whose agendas they did not endorse, making this category the sixth most-rejected group of "others." 
(always treacherously!) plot against the noble, unsuspecting, intrinsically national majority. The thus-produced enemy is made responsible for the social ills that affect individual people and individual families who are made redundant, cannot find new jobs and are forced to re-make their lives. At the same time, new houses are built next door, people make careers and individuals get rich; how is that possible in an allegedly democratic world? Equality and equal laws for all are the symbols of this world, yet only some really enjoy success in it. In this way, we arrive at the backdrop against which it is easy to build a new community of the disappointed and disaffected who defend themselves by accusing the entire world (in particular the successful ones) for letting this happen. They do so even if their own situation is not bad at all; but when aspirations, strong as they are, are not satisfied, we end up with an excellent psycho-social material for a community of hateful enviers, which especially thrives when an ideological form and an emotional expression are found which can serve as a political view and the foundation of political mobilisation.

Emphatically, this is where sociology and politics intersect as a pretty populous representation of a certain social mentality is assembled and expressed in a political project. For I believe that these resources of social mentality are consciously and deliberately mobilised by the $\mathrm{LaO}$ leaders.

Factor 3 - religious political correctness (2002)

Acquaintance with a person who condones abortion - 728 Acquitance Acquaintance with an atheist - 597 Acquitance Acquaintance with a feminist - 571 Acquitance Acquaintance with a member of a disliked party - 494 Acquitance Acquaintance with a passive unemployed person - 484 Acquitance Acquaintance with a former communist - 403 Acquitance Acquaintance with an alcoholic - 384 Acquitance
1. Prostitute
$648 \quad 69.1$
2. Homosexual
$635 \quad 67.7$
3. Alcoholic
$530 \quad 56.5$
4. Gypsy
$471 \quad 50.2$
5. AIDS patient
$394 \quad 42.0$
6. Member of the party whose agenda I don't endorse
359 38.3
$\mathrm{N}=938$ valid answers 



\section{Solidarity: Experience and Memory. Narratives of the Activists of the Gdansk Region}

When the Solidarność - doświadczenie i pamięć (Solidarity: Experience and Memory) project was being launched, the Mayor of Gdansk Paweł Adamowicz was very enthusiastic about the venture and planned on encouraging local selfgovernments to support the relevant field research in several Polish cities. The idea was for the local self-government agencies to co-fund the continuation of the qualitative study, including a series of short publications devoted to individual cities and towns. While the idea however proved difficult to execute, the Municipality of Gdansk indeed provided enough funding to conduct field research in Solidarity's old Gdansk Region.

The funding helped us carry out studies in Elbląg, Tczew and Gdansk itself as the cradle of Solidarity. Earlier, in the first stage of our research in the TriCity, we had conducted there as many interviews as in the other cities and towns; but given the special relevance of Gdansk and Gdynia to the rise of the Solidarity social movement, we were happy to augment the data we had previously collected.

In this account of the project findings in Solidarity's former Gdansk Region, I would like to focus above all on some new data, new information and slightly different phenomena than those we had found in the study's first phase. ${ }^{220}$ Of course, I will mention what seems consistent with the data generated in the first stage of our research as well. In particular, I will briefly discuss essential data that corroborate the hypotheses we had adopted in our project.

\section{Small Town vs. Big City}

Our first crucial observation is that people's situation and activities differed between cities and towns. Previously, most data were collected in Poland's big and even largest cities, such as Warsaw, Cracow, Poznan and the Tri-City. Basically, only one study carried out in the Świętokrzyskie Region concerned smaller towns of Skarżysko-Kamienna, Ostrowiec Świętokrzyski and Starachowice.

220 Ireneusz Krzemiński et al., Solidarność - doświadczenie i pamięć (Gdańsk: ECS, 2010); see also Ireneusz Krzemiński, "Pamięć Solidarności w świadomości społecznej," Wolność i Solidarność. Studia z dziejów opozycji wobec komunizmu i dyktatury 1, 2010, pp. 48-59. 
Certain issues reported in these towns were directly clarified by the data from Tczew and Elbląg. Specifically and importantly, people feared reprisals that could be inflicted on the organisers of the new trade union as well as on those who simply joined the Solidarity movement. The actual reprisals and the dread of them became probably even more relevant in the dark years of martial law, i.e. in the 1980s.

On the whole, big-city dwellers tend to have difficulty imagining how closely knit people are in small towns and, consequently, how easy it is to obtain information about them. In such places, the job of security services was far easier than in large urban agglomerations. At the same time, however, the personnel of the People's Militia, as well as of other repressive agencies of the state, army and special services, were far less anonymous in small towns than in big cities. Still, even though the transparency of interpersonal bonds could counterbalance the facility with which the repressive bodies operated in small towns, their residents had certainly every reason to be more afraid to get involved in illegal activities than big-city dwellers. While those who vented their dissent very privately could expect their acquaintance from the power apparatus to look the other way, full and socially effective engagement was far more dangerous.

This is what I conclude on the basis of our data and the experience of martial law years. "People were regularly intimidated," a respondent states (01), emphasising that "it may not have been so awfully dangerous, but people generally felt that if you didn't stay low, the regime would crack down on you." Such observations also appear in interviews concerning martial law. The idea recurs in group interviews as well, showing that to join Solidarity in a small town took more courage than it did in a big city. Of course, Gdansk was and still is the point of reference for the residents of both Elbląg and Tczew. Admittedly, strikes held in solidarity with the Gdansk Shipyard strike were very common in Elblagg. Telex 123 sent at $6 \mathrm{pm}$ on $18^{\text {th }}$ August 1980 reads: "At the moment, no work activity is going on at the Provincial Communication Services, the Municipal Sanitation Services, the Great Proletariat Factory, the State Motor Transport, the Elbląg Ship Machinery Factory, the Elbląg Automobile Repair Works, the Truso Textiles and the Automobile Fittings Manufacture." The list omits the Elbląg Integrated Construction Plant. ${ }^{221}$ This made things easier. A solidarity strike was also organised in Tczew; in fact, it was a series of strikes, commenced at the local Motor Transport Company and picked up by the Municipal Motor Transport,

221 In Elbląski Portal Historyczny, Biblioteka Elbląska im. C. K. Norwida (www.historia. bibliotekaelblaska.pl/artykul/1429). 
both enterprises joining the Gdansk-based Inter-Enterprise Strike Committee. Yet the strike movement was less robust in Tczew, while fears were greater there, which was clearly linked to the town's size. I mention the solidarity strikes quite deliberately, for wherever strikes were launched, workers of various enterprises (even those uninvolved in the strikes) were quicker to set up their own trade union units after the August agreements had been signed.

There question of fears and overcoming them is associated with the presence and activities of the local elites and authority figures. While the Gdansk interviews attribute a lot of relevance to the intelligentsia's support for workers, in both smaller towns the respondents imply that, rather than setting an example of civic action, the intelligentsia (or at least people with jobs in offices) were more scared. This, again, is understandable in view of the dense network of connections and dependences: people in high positions were far more visible than workers and, consequently, more dreaded losing their jobs, even if their hearts went out to the new trade-unionist movement. In the Elbląg study report, Justyna Nesterowicz-Wyborska writes: "Without articulating this issue directly, the respondents seem to deplore the insufficient number of engaged leaders, therein mainly the inadequate involvement of the intelligentsia in Solidarity and during the martial law years. This problem is often addressed when assessing engagement, the effectiveness of strikes and inter-enterprise collaboration." This practically meant an important difference between strikes in smaller towns and in Gdansk, where in most enterprises, including the Gdansk Shipyard, the strikes were organised and joined equally by workers, foremen, engineers and some white collars. A Gdansk respondent confirms this insight: "So, as regards the intelligentsia, that is, if we talk of the intelligentsia, because, mind you, the intelligentsia' is a broad term, I personally felt that the intelligentsia helped us a lot, because we had contacts with them" (Gdansk, resp. H). The author of the Tczew report emphasises that in this town workers enjoyed far less support from their superiors, let alone from the frightened office personnel.

At the same time, greater fear made workers more reserved, as a result of which the intelligentsia - office workers in particular - were not viewed with a kind eye. As a result, it was rather difficult to go on strike together with workers, as our respondent, a Zamech ${ }^{222}$ accounting clerk, recounts: "It wasn't easy to join

222 Zamech (Zakłady Mechaniczne ZAMECH im. Karola Świerczewskiego; English: Karol Świerczewski Mechanical Works ZAMECH) was a major industrial plant in Elbląg. (translator's note) 
the blue collars, because they treated the clerks like 'the director's moles.'" She was helped by her blue-collar family who vouched for her (Elbląg).

As there were several reasons for the smaller engagement of the intelligentsia in the early stage of the development of the social movement in small towns, there were also several, sometimes surprising, consequences of it. For example, workers tended to consider the intelligentsia better prepared for and more knowledgeable about formal aspects of collective action and to ascribe the authority role to them. When the intelligentsia offered no help and did not engage in joint action, it was difficult to work out a modus operandi, especially one that differed from the patterns implemented under the People's Republic of Poland. The point is that this quandary concerned no trifling matters, as at stake was, for example, how to organise a discussion, how to hold equitable and democratic elections, etc. The intelligentsia could also use their knowledge and skills to arbitrate, as an authority, in conflicts that escalated within the striking and then unionising workers' communities. Interestingly, our respondents addressed this point themselves: it was easier for big-city workers, they had their authority figures, their educated people who could temper disputes, make them more to the point, bring a conflict to an agreement. This may reflect the symbolic influence exerted by the advisors of the Inter-Enterprise Strike Committee at the Gdansk Shipyard. At any rate, I believe this fact should be stressed because, after all, big-city factory workforces were certainly more self-assured about their own competences and had more differentiated ideas about the role and participation of educated people, i.e. the intelligentsia. Importantly, the trade-unionists were wary of making their movement subordinated to the intelligentsia leadership both in 1980-1981 and as the trade union movement developed later. This guardedness was emphatically showcased during the $1^{\text {st }}$ National Congress of the NSZZ Solidarity in Gdansk Oliwa.

Differences in memories and interpretations of the Solidarity-related past are also patent when our respondents talk of motivations for joining the unionist movement. In the first stage of our study, we had already found some differences in portrayals of the situation prior to the August 1980 strikes and in reasons why, according to the respondents, people had joined protests and then got involved in the trade-unionist movement. Our respondents from the Swiętokrzyskie Region (i.e. Skarżysko-Kamienna, Starachowice and Ostrowiec Świętokrzyski) had differed somewhat from the residents of Poland's big and largest cities. Now, the interviewed activists of Elbląg and Tczew emphasised the poor financial situation, subpar standard of living and unjust access to material goods far more than the activists in Gdansk and other big cities. Poverty, the unavailability of 
goods and the unjust distribution of wages were foregrounded as reasons for launching protests and then joining the Solidarity movement.

This is not meant to imply that the activists and members of the trade-union movement in big cities did not talk a lot about the economy and people's poor living conditions. However, in big cities, justice and freedom were far more powerfully stressed than in towns. The report states, among others, that "generally, the strike was launched and joined because of the common dislike of the People's Republic of Poland." This dislike was caused above all by very poor availability of goods needed in daily life, a factor mentioned by all the respondents. As supplies were lacking, all people had to find ways to cope, helping each other out within families and friend groups, while they devoted their time to domestic engagements. Side by side with the economic problems, the respondents also cited the negative atmosphere linked to the aloofness of power-wielders vis-à-vis ordinary people. Summarised in this way, the Elbląg interviews imply that the dislike of the People's Republic of Poland had chiefly economic overtones. Yet, there are interviews which register attempts at arranging motivations in a kind of hierarchy: Solidarity is usually perceived as a social movement committed to welfare and liberty which developed under the banner of a trade-unionist movement. Some respondents state directly that the focus on living conditions could serve to mobilise and consolidate people, while the patriotic ideas were put forward immediately afterwards. A respondent from Gdansk says: "It seems to me that it wasn't only about the economic frustration, but also about debasing people, I guess. People already knew that the regime was debasing them. I also didn't accept such debasement, people being treated like... as if they had no rights." Another respondent from Gdansk says: "We were preoccupied precisely with such matters of the soul rather than of the body. And this has changed now so much that I think back nostalgically on those conversations till small hours, eating hard-boiled eggs" (Gdansk, resp. E). So the concerns of the body were not the only focus, but people also attended to the concerns of the spirit, that is, the spirit of freedom and respect for the human being.

Additionally, class- and stratum-membership is differentially associated with motivations to get involved in action and to join the new trade union. As Nestorowicz-Wyborska observes: "Importantly, some respondents attribute different motivations and aspirations to different social groups; specifically, freedom-related motives are ascribed to the intelligentsia, while workers' communities, in particular workers hailing from rural areas, are identified above all with the struggle for better livelihoods and living conditions" (Gdansk). Nevertheless, even though in their interviews the activists of Tczew stress the economic and financial matters, these concerns involve a sense of injustice as 
well: "Honestly, the pay-rises were the main impulse... the privileges that the United Workers' Party kept for themselves, this struck people first of all. They had their canteens, their shops, their positions from cradle to grave... Social inequality. This annoyed people a lot" (Tczew).

Although people's motivations (and the weight of respective motives) are differently distributed in big cities (e.g. Gdansk) and smaller towns (e.g. Elbląg and Tczew), all our respondents very similarly interpret the fundamental meaning of people's engagement in the strikes and protests of 1980 and of their involvement in the establishment of the Independent Self-Governing Trade Union "Solidarity."

\section{Motives and Goals of Social Action: The Solidarity Movement as the Basis of the Trade Union}

Let me start with a quote: "Solidarity is most frequently perceived as a social movement committed to welfare and liberty which operated under the banner of a trade union. Some respondents state directly that the focus on living conditions could serve to mobilise and consolidate people, while patriotic ideas were put forward immediately afterwards." This implies that resentment caused by life hardships combined with injustice spawned a more general demand of national freedom. Without a doubt, describing their motives for action and the fundamental goal of initiating the social movement, which was to lead to the founding of an independent trade union, the respondents mention two demands: livelihood- and welfare-related on the one hand and national independence-focused on the other. The very genesis of the movement, as addressed by our respondents, is a compelling issue because they state that from the very beginning Solidarity was a social movement which could operate under the banner of a trade union. Later, as the respondents conclude, this splicing proved fatal both to the Solidarity movement and to the trade union Solidarity (we shall return to this issue when assessing the past and the current Solidarities). "According to the respondents, from the very start, Solidarity included two currents, one focused on national liberation and the other dedicated to welfare. For people from outside big cities, the focus on the living conditions was important. even though they also recognised the relevance of the right that people and employees should have to be treated with dignity. Differences in their social status notwithstanding, all the respondents claim that Solidarity was a social movement. One subject was even corrected by the others when he talked of 'a trade union,'” as Tomasz Tobis concludes in his report on the Tczew findings. Notably, the respondents clearly stressed the 
difference between the residents of the "small" Tczew and big-city dwellers (e.g. in Gdansk).

Examined carefully, the quotation above yields three basic elements in the typology of the activists' motivations: the welfare factor, the patriotic factor and the human and employee's rights factor. In our data - both in the transcribed interviews and in reports from all three sites - people's motivations and goals are clearly simplified and only reduced to two elements: livelihoods and national liberty. But in fact, as can be gleaned from both Gdansk and Elbląg interviews, the welfare factor included a varied bundle of values and demands. The bad financial situation and poor living conditions of people employed in the state economy, which contravened the regime's declarations and promises, combined with chaos, nonsensical socialist economic decisions and inefficient management - all this indeed stirred people's protest. Yet, at the same time, people were incensed by unjust privileges, which, if anything, wrecked the organisation of labour (incompetent people in executive positions); they were enraged by inequitable wages, the unfair distribution of goods and the flouting of employees' - but also human and civil - rights. The question of dignity is nearly always addressed when the respondents describe workplace relations and the communist political system. Based on the Tczew data, Tobis observes:

An overwhelming majority of people actively involved in Solidarity wanted socialism "with the human face," a socialism without distortions. Revindication and welfare were the most important and strong motivations as people called for improving food supplies, demanded revoking coupons, insisted on putting an end to goods rationing and wanted financially decent lives. The birth of Solidarity was triggered first and foremost by the government's failure to solve livelihood-related problems. This means that poor living standards, low wages and the lack of decent living and working conditions were the main reasons behind the social revolt.

Another relevant motive involved restoring moral dignity and subjectivity to people. This is emphatically articulated by R3: “'Solidarity' was something beautiful, something great, people felt appreciated, important, acknowledged by others - they felt they mattered. It was a movement of joy, of awakening from being stifled by the atmosphere of life in the People's Republic of Poland. You felt connected to other people, be it just by communicating with each other - this bred solidarity among people. It was a huge social movement. Every person was important and had an opportunity to shine."

And the third essential motivation that fuelled people involved in the "first" Solidarity involved the patriotic and historical investment. A few respondents refer to this issue and R4, one of the youngest activists back in 1980, even states that this in fact mattered most to his group. They wanted history put straight ["unlied" as it was worded then], the truth about the Katyn massacre and freedom of expression. Katyn symbolises the mendacity of the officially propagated version of Poland's recent history and its relations with the Soviet Union. The goal was to put an end to the omnipotent arbitrariness and 
arrogance of the Party functionaries. R4 depicts Solidarity as a self-limiting revolution, where self-limitation refers to the collapse of the impetus to repair Poland caused by the Round Table. (Tomasz Tobis, Tczew) ${ }^{223}$

Here, the rights of man and the citizen appear in conjunction with the idea of national liberty and a poignant assessment of the supremacy of the unaccepted Party. This leads us again (as was the case with the data from the first, core stage of our research) to Alain Touraine's hypothesis of the Solidarity movement's tripartite goals and values. Touraine's "triad" included trade-unionist aspirations (demands focused on welfare and equitable industrial relationships), democratic aspirations (subjectivity of civil society and insistence that the state respect the Rights of Man and the Citizen) and independence aspirations (the capacity of Poland's citizens to decide about their fates and the fate of the state, i.e. liberation from subjection to the Soviet Union).

I believe that various statements both in individual interviews and in focusgroup discussions indicate that the independence aspirations were ultimately stirred by the perceived humiliation, the feeling that people as employees and as persons were treated with contempt and the sense of being denied human and civic dignity. "In my opinion, it was all caused by... by the feeling of enslavement. And, secondly, by bewilderment that so much was produced, but nothing was ever to be got. [...] So everybody felt that some insurrection was in order, but how to do that?" (Gdansk). In my view, "enslavement," as used in this interview, seems to aptly encapsulate the denial of dignity. Besides, as already mentioned, the respondent tellingly refers to the inefficiency of the socialist economy, in which ineffective labour was divested of any dignity: hard work produced no perceivable outcomes, which made it pointless: "It boils down to one thing, namely that livelihood without liberty is like tearing one off from the other. That's exactly how things are here [...] Only independent information makes you look at all these things in a different way." The respondent goes on: "For today, despite appearances, life is more difficult than [back then] [...] back then you had enough for your chow, but there was nothing to get except that chow. People weren't even particularly angry about that, because they had no comparison, not a clue what things might be like, only when the thaw came, all information, all those things that happened after 1980" (Gdansk, respondent F from the working-class background).

223 R4 and similar letter-and-number combinations encode individual interviewees of Tczew. 
In conjunction with the observation in the Tczew report that many people who were to become Solidarity activist just wanted "socialism with the human face," similar statements were registered during last year's core research. I must admit that the popularity of the "socialism with the human face" wording is, basically, rather surprising. As far as I remember, the term certainly was not used with any special frequency by the members of the Solidarity social movement in 1980 and 1981. The expression did not feature frequently either in Touraine's study or in our interviews with the founders of the NSZZ "Solidarity" in Warsaw. ${ }^{224}$ Even Jan Strzelecki, a member of Touraine's research team, did not refer to "socialism with the human face" back then, even though it was a common slogan among the proactive, progressive, post-October intelligentsia. In the 1950s and 60s, the coinage expressed liberal and pro-democratic attitudes. Of course, it was socialist liberalism, which sought some enlargement of people's freedom and a reduction of the real-socialist state's control functions.

The fact that this slogan recurs in both individual and group interviews in the context of people's motives and the goals of the trade union movement, should certainly be explained. I can give no explanation of it here other than the belief that this aspect had been largely absent in 1980-1981 and was only later planted in the consciousnesses and memories of most of our respondents. It is all the more intriguing as "socialism with the human face" was, by and large, the intelligentsia's slogan, paraded and touted in by no means commonly read magazines such as, notably, Po prostu. I believe it was in this magazine that the slogan first appeared to be later vocally advocated by its editors. Yet the "socialism with the human face" catchphrase is reiterated in our interviews not only by the intelligentsia, but also by workers, even by those who were very young in the 1950 s and 60s, or were born later (as is the case with one of our very important Gdansk respondents).

Such phrases might have been used in articles published in trade-unionist papers and brochures across Poland in 1980-1981. It is not impossible because the trade-unionist movement, in particular the institutional agencies of the NSZZ "Solidarity," were very careful not to defy socialism directly. In this context, "socialism with the human face" was useful as a slogan which the party-state could not possibly combat and which helped freely express aspirations to create an order based on respect for civil rights.

224 Ireneusz Krzemiński et al., Polacy - jesien' '80 (Warszawa: Wydział Filozofii i Socjologii UW, 2005). 
This is indeed the context in which the slogan is used in the interviews; it appears when people describe how their attitudes evolved. As before, the data from the Gdansk Region basically imply two attitudes to the People's Republic of Poland. One of them is an attitude that evolved from the initial acceptance of the system and the belief in its ideological declarations to a criticism of and a revolt against the party-state. It can be called an attitude of disappointment with and rebellion against the system. The other attitude involves a critical non-acceptance of or, even, enmity towards the regime, developing since childhood or adolescence. It can be called an attitude of distrust of and aversion to the system.

Very often, people in whose homes the system was resented - not infrequently because of historical knowledge, for example, about the Katyn crime - were rather cautious not to voice their criticism and reveal their attitudes openly. They were only outspoken among the trusted friends. One of our Gdansk respondents (interview A) belonged to this category: while thoroughly critical and not amenable to the manipulations, propaganda and misinformation of the regime's media, he had internalised a very strong fear of the system (and, as such, he did not join the $\mathrm{ROPCiO}^{225}$ despite his loyalty to the movement).

In the second stage of our study, the interviews in Gdansk tackled the previously unaddressed theme of the Borderlands experience. As is well known, many re-emigrants from Poland's former Eastern Borderlands settled in Gdansk in the aftermath of the Second World War. The dramatic events they had gone through with their families under the wartime Soviet occupation tended to powerfully affect their assessment of the communist order and motivated them to undertake independent action as soon as they felt relatively secure to involve in social activity. It was exactly his family tradition linked to pre-war Vilnius that formed the mindset of respondent B of Gdansk: "I was brought up amidst very strong patriotic sentiments. We sang the Legions ${ }^{\prime 226}$ songs at home. I've been told about free Poland since I was a young child. By parents and grandparents alike." The respondent continues: "Generally, there wasn't much talk about it, about fear. That's what needs to be done, I thought. My grandparents saw the Legions, the Bolshevik war and, later the Second World War; what's going on now is an idyll

225 ROPCiO is the acronym for the Ruch Obrony Praw Człowieka i Obywatela; English: the Movement for Defence of Human and Civil Rights. (translator's note)

226 "The Legions" refers here to the Polish Legions (Legiony Polskie), a Polish military unit formed within the Austro-Hungarian Army by Józef Piłsudski in 1914, when Poland was still partitioned. Though relatively short-lived, the force fought in a number of battles during the First World War, and its memory has been cherished in the Polish patriotic tradition till this day. (translator's note) 
compared with what they were through" (Gdansk, interv. A). In her report on the Gdansk findings, Justyna Nestorowicz-Wyborska observes: "The symbolic words that appear in this narrative about the ancestors and their wartime experiences include 'the Vilnius Region,' 'Haller's Army', 'the Bolshevik war,' 'the saga of Pilsudski's Legions,' 'the Pilsudski-ite,' 'the Soviets,' 'the Siberia saga,' 'Kozielsk,' 'Anders' Army,' 'Monte Cassino,' 'the Polish People's Army,' 'the $3^{\text {rd }}$ Division of the Polish People's Army', 'the battle of Berlin.' Importantly, the ancestors' tradition of struggle for national liberty was also the tradition of the Borderlands, as emphasised by the respondent. As he observed during the interview, ${ }^{227}$ it had been a key factor in shaping his later life and perception of reality, defined, basically, as the communist enslavement; today, this investment shows in his robust interest in history."

The Borderland tradition was slightly differently expressed by an Elbląg respondent: "Because my parents, and they were really fantastic people, and I had a great family home. But as regards politics, they never talked about it with the kids. I guess they thought it dangerous. They became more open after 1980. Perhaps, it was so because my parents came here from Lviv, and they still remembered what the NKVD had been doing, the Bolsheviks, all that, and believed it was... They were still afraid of everything. And I was raised in complete ignorance, I'd say" (resp. 03, Elbląg). Nevertheless, on most occasions when the respondents mention the Borderlands tradition, they voice a special, critical, distrustful or straightforwardly loathing attitude to the regime, even if their parents and grandparents did not "become more open" after 1980.

\section{The Relevance of the Earlier Experiences and Protests in the Coastal Region}

While, generally speaking, the formation of such a widespread and disciplined social movement as Solidarity was could hardly be envisioned without the prior phases of workers' protests, for most areas of Poland such experiences were relatively fresh and strictly bound up with the "hot summer" of 1980. The feelings were different in Gdansk and, as it turns out, in the entire Gdansk Region as well. Of course, the key factor was the experience of December '70, but - apparently - it was not the only one, as the mass protests of students in 1968 were also deeply etched in the memory of the residents of the Tri-City, Tczew and, above all, Elbląg. The view expressed in one of the focus-group interviews in Gdansk is

227 Also before the interview formally commenced, i.e. before it started to be recorded. 
indeed widely shared: "I think that all this started more or less in 1970 and later just grew on. And it culminated in the period when Solidarity was developing" (Gdansk). In Elbląg, a respondent recounts the 1968 and 1970 events in more detail. At the time, she was a student at the Gdansk Technical University and now views this period as a "political initiation" (interview 03). She treats the Gdansk events as an important experience in her life: she was part of the student board which was supposed to meet the Gdansk Shipyard workers, and she took part in students' meeting with the leader of the Socialist Youth Association (Związek Młodzieży Socjalistycznej), which paradoxically "opened her eyes" to many issues (Elbląg, Karolina Ciechorska-Kulesza). The Elbląg respondents also often mention the December ' 70 events and the shooting of the shipworkers in Gdansk and Gdynia, which is understandable as young workers hailing from Elbląg were among the victims. A TV film about the December events says that the man who was shot dead and carried along the Gdynia streets was a twenty-one-year-old from Elbląg.

But, interestingly, many respondents observe in individual interviews that their anti-system sentiments were catalysed by the far earlier "Letter of the Polish Bishops to the German Bishops" of 1965. ${ }^{228}$ A respondent from Elbląg says: "Of course, there was a huge uproar by the government that it was national treason and so on. But we, they young, liked that letter a lot. We were all for handling things in this way" (resp. 03, Elbląg).

In the Gdansk interviews, the practical lesson of the December '70 events was also emphasised: in 1980, people were careful to keep the strike from spilling into the streets and to lock themselves up at the factory, taking responsibility for the property at the workplace. Taking to the streets came to be associated with the deadly shooting the government had ordered against the workers in December '70. I will not dwell on this issue because it was also addressed in the first stage of our research. The current data from Pomerania re-confirm that people commonly remembered the imperative of striking within their enterprises and avoiding going out to manifest in the streets. This was the effect of the social memory of December ' 70 and the lesson learned from those experiences. As one

228 What is meant here is "The Pastoral Letter of the Polish Bishops to Their German Brothers," in which Polish bishops invited their German counterparts to take part in the celebrations of the $1000^{\text {th }}$ Anniversary of Poland's Christianisation and reflected on the Polish-German history, famously offering forgiveness and asking for forgiveness. (translator's note) 
of our respondents says: "December'70 was a real trauma. In comparison, the year 1980 was nothing” (Gdansk, resp. C).

\section{Past and Present Divisions and Conflicts}

Our current data from Gdansk, Tczew and Elbląg paint a far more vivid picture of a fundamental conflict among the former Solidarity members than the prior nationwide data. Admittedly, those data indicated a clearly critical attitude to Lech Wałęsa in some towns, but it was nowhere near as keen as what the current findings imply about the conflict between the supporters of the former Solidarity leader turned President of the Republic of Poland and the followers of the Gwiazdas. Both the interviews and the analyses employ telling expressions borrowed from the colloquial language used in the Gdansk Region, such as "Lechistan" (the Wałęsa camp) and "Gwiazdozbiór" (the Gwiazdas camp). ${ }^{229}$ In group interviews (particularly in Tczew), the respondents recall that the independence-oriented, or national liberty, wing within Solidarity clashed with the livelihoods-focused, or welfare, wing, as already mentioned. The trade union was associated first and foremost with the welfare concerns, but the social movement went far beyond that preoccupation and envisaged national independence. A respondent said: "But there were many people [...], from the countryside for example, who did not cultivate the tradition of national liberty. Secondly, many people didn't think it was possible to find a way out of the situation Poland had found itself in after 1945. And because of this, they thought that the economic issues were essential. Many of my friends, especially perhaps from the workingclass background, were more focused on... thought of it as a trade union that would take care of my economic interests. 'And what are they meddling with politics for,' that's what our conversations were often like. I'd distinguish two groups, exactly like that. A group that [was] absolutely trade-unionist and focused on the economy and a group that [cared] less about the living conditions and more about liberty ..." (Gdansk, resp. B).

This interpretation of the conflict, which is clearly observable even today, is rather peculiar and differs from the genesis of disagreements and the mutual dislike between the "Lechistan" and the "Gwiazdozbiór" as outlined in the Gdansk

229 The terms use play on words. Lechistan means "the country of Lech," with Lech being the name of both the legendary founder of Poland and Lech Wałęsa. "Gwiazdozbiór" is the Polish equivalent of a "constellation" and a compound noun derived from gwiazda (star) and zbiór (set), which directly refers to the name of the Gwiazdas, i.e. Andrzej and Joanna Gwiazda, prominent opposition activists. (translator's note) 
interviews, which link them to Andrzej Gwiazda's loss in the election of the trade union's president in the autumn of 1981. Our respondents in Tczew also interpret the conflict between the supporters of Wałesa and Gwiazda, respectively, as an outcome of power struggle. Interestingly, people state that: "Wałęsa was our guy, a worker, and Gwiazda was then an intellectual, for he had university education ..." (Tczew). Tobis describes the image of the past as seen by the Tczew activists in the following way: "[The respondents] in the lower rungs were, as they claim themselves, divided into two camps: siding either with Wałęsa or with Gwiazda, yet this did not cause any conflict but only some joking and teasing. They emphasise that despite the differences they treated each other with respect and dignity" (Tczew).

The memories of one Elbląg respondent imply that the conflict was already evident in the legal period of Solidarity's activity. Respondent F from Elbląg narrates a visit to Nowy Targ in detail:

I was there; we came there for that dinner, twelve people in all. Andrzej Trupa [possibly the name was misspelled in transcription] was there, too. And Andrzej tells me: 'T... [the respondent's name], don't you see what's going on? Look, Wałęsa's putting himself forward everywhere as one to scoop credit for all this.' And when Ania ${ }^{230}$ wanted to say something, I remember, in Nowy Targ, there was a moment where we're all sitting there and Wałęsa too, and, right, Andrzej Gwiazda winks at us, and then the boys, from Elbląg I guess, go "Lech, you’ve already spoken." Everybody starts shouting: "Ania, Ania." Wałęsa was eager to take all credit, but he was only the first relay. "Ania, Ania," everybody's crying spontaneously. It wasn't about people but about politics, not about trade unions. Then the social movement began to split. Then Walentynowicz said those famous words that: "I've got three things dear to me: Our Lord is most important, I respect John Paul II and carry Solidarity in my heart." She got a spontaneous round of applause. We left and Wałęsa says [to her?]: "Just had to mess around, didn't you?" And I say; "Lech, it's not the way to go, or we'll be all at each other's throats like dogs." And then it all broke loose. It was then that I noticed for the first time that Wałęsa was soft. But all of them [the supporters of Gwiazda] were radical, tough players. (Elbląg, resp. F)

The author of the Elbląg research report observes that at this moment the split into the "Lechistan" and the "Gwiazdozbiór" becomes clear for the first time. In further interviews, the division is emphasised when the respondents talk about the imposition of martial law, assess the Round Table and evaluate contemporary Poland (though names are rarely used, except Wałęsa being mentioned a few times, and Gwiazda and Walentynowicz one time each). The author also

230 Ania is a very popular Polish endearment of Anna. Ania here refers to Anna Walentynowicz. (translator's note) 
observes that, as a rule, the ideological differences, conflicts and divisions within Solidarity are brought up by people who critically evaluate Lech Wałęsa's actions. Other respondents either do not address that issue or underscore Solidarity's positive, integrative aspects (respondents 03 , F, Elbląg).

This longish passage exigently outlines the background of a very sharp, current conflict among the activist of the "first" Solidarity. Anna Walentynowicz, who tragically died in the Smolensk catastrophe, is pitted against Lech Wałesa both in the above narrative of the Elbląg respondent and in other interviews conducted in other towns. Obviously counted among the "Gwiazdozbiór," Walentynowicz is regarded as enjoying considerable recognition among the movement members and as a counterweight to Wałęsa as the trade-union leader. Such conclusions are also corroborated by the Gdansk data: "Walentynowicz took over the initiative entirely and came up with the idea of holding a mass on $17^{\text {th }}$ [August 1980]. And... she transformed this strike. At any rate, the mass on $17^{\text {th }}$ [August] lifted that sense of fear and threat off me and other people" (Gdansk, resp. G). Crucially, Anna Walentynowicz is credited here with salvaging the strike at the Gdansk Shipyard, which is particularly strongly emphasised by all the supporters of the "Gwiazdozbiór." The opponents of Lech Wałęsa tend to view it as a factor that delegitimises his leadership. However, our interview data from, for example, Tczew do not imply such radical positions, though divergences indeed become definitely more pronounced when the respondents shift from their past memories to the assessment of the present times. In the Tczew focus-group interview, the respondents manifest rather untypical attitudes, as they negatively evaluate the current Solidarity trade union. By contrast, the Gdansk and Elbląg interviews, as well as the first-stage research data, express a relatively homogeneous attitude which combines the support for the "Gwiazdozbiór," a critique and dislike of Wałęsa, an even sharper criticism of present Poland, an aversion to the current government, the support for the $\mathrm{LaO}$ and the positive appraisal of the current Solidarity. ${ }^{231}$

Many or our respondents both from Gdansk and from the towns of Tczew and Elbląg regard conflicts within Solidarity - above all the basic conflict around the trade-union leadership - as a permanent element of the social movement. Moreover, their descriptions of the conflict between Lech Wałęsa and Anna Walentynowicz or Andrzej Gwiazda in 1980-1981 transition smoothly into depictions of the current situation. It is difficult to conclude, at least on the first

231 Our study and the trade-unionists' views concerned the leadership of Janusza Śniadek, who was then the union's president. 
examination, whether that conflict was indeed so deep-running and so impactful socially (organising the trade-unionists as either the followers of Lech Wałęsa or the supporters of Andrzej Gwiazda and Anna Walentynowicz) as early as in 1981, or perhaps, the other way round, the post-1989 conflict retrospectively produced such and not another image of the past. At any rate, in the late 1980s, but still before 1989, the conflict between Solidarity leaders caused the rise of the Gwiazdas' camp with Anna Walentynowicz as its integral member. Described in more detail below, this development involves a very important and, simultaneously, very challenging aspect of the study of people's memory. Namely, it is difficult to determine what part of our interviews is a tolerably accurate and factual report of the respondents' real experience and what is an outcome of interpretations indivisibly entwined with and re-organising their memories. In other words, what is actually a memory here and what is an already re-processed image of the experience?

It is not my aim here to theoretically explore my findings. I intend to do it in another study. But I must observe that the very way in which the respondents themselves presented their memories, both in individual and in group interviews, helps us set apart those in which "memory work" is consciously shown by the interviewees from those which the researcher must analytically filter in order to distinguish the objective record of the past from the later, superimposed interpretations. The developments we are discussing here, i.e. the WałęsaWalentynowicz and Wałęsa-Gwiazda conflicts - regrettably belong to the latter group, which is rather opaque in the initial analysis.

Important in this context is the above-quoted observation made by a respondent and corroborated in a group interview that even if the leadership conflict arose in 1981 and even if it divided the members and activists into the Wałęsa or the Gwiazda followers, this conflict did not fundamentally affect people's attitudes and ideological identifications. The conflict showed in "joking and teasing" rather than in any stern confrontation of thoroughly different ideals. Confrontational behaviours and divergent investments started to be attributed to the conflict after 1989, and particularly intensely today.

An interesting thing to observe is how reductively - and, in a sense, tyrannically - time is treated in this context: in the picture painted by Wałęsa's opponents and the supporters of the "Gwiazdozbiór," the emotionally laden assessment of the present moment is extended onto 1989 and the events that instituted a new order for Poland. The objections to the Round Table and the charges against Lech Wałęsa and his then allies who organised the negotiations between the Jaruzelski cabinet and the underground Solidarity inform the descriptions of the current conflict. In the view of our respondents, the Wałęsa vs. Gwiazda conflict gathered 
momentum and definitively divided Solidarity members during the Magdalenka negotiations and the Round Table talks. We can see a certain hyperbole at work here as a very explicit, current conflict situation basically overlaps with the image of the past. The interpretation of the past events is encrusted, so to speak, into the meanings of the present conflict. This obviously refers to a considerable part of our respondents who are fervent supporters of the "Gwiazdozbiór." At the same time, they are also supporters of the Law and Order, which we will attempt to show below.

Before that, however, let us outline an alternative picture of the events which crowned the Solidarity movement as the Soviet system collapsed and Poland obtained its first post-war non-communist government. People who positively assess both the Magdalenka talks and the outcomes of the Round Table have an entirely different view of the "primary conflict" that bred such an essential dispute and split society, generating patently differentiated social identifications. Namely, they refer to the "thick stroke" ("gruba kreska"), i.e. an essential element "read out" from Prime Minister Tadeusz Mazowiecki’s exposé and re-worked for Lech Wałęsa’s election campaign. I put "read out" in inverted commas, because the "thick stroke" slogan and its symbolic content, which has been so relevant to social consciousness ever since, were a serious modifications of the original "thick line" ("gruba linia") coinage in Mazowiecki’s exposé. It was actually the "proper meaning" of the term that was at stake in the heated discussions of the Pomerania activists in our focus-group interviews. The advocates of the Round Table (and consequently of the Mazowiecki cabinet) cited the exposé formulation as having an entirely different meaning than the one invested in it during Wałesa's campaign and wrongly attributed to Mazowiecki. Here is an extensive passage from our Gdansk resources. The same people are of the opinion that the "thick stroke" was a good thing. The respondents who uphold this position emphasised in individual interviews that their opponents misconstrue the concept $(03,01)$. This issue also brings to light anti-revisionist attitudes to people involved with the PUWP:

And from the very beginning, we kept explaining it to people that the "thick stroke" was not what the opponents made it out to be. It was just vilely used, because the thick stroke meant that he said in his exposé that we are drawing a thick line between the past and the present and from now on we work for and by ourselves. It means, we won't build on what was, but we'll have a fresh start. [...] Anyway, I'm quite surprised because, in my opinion, those who did little back then are most vocal now about punishing those alleged culprits of the communist period [...], I'm surprised at this inclination now to rub it into people's faces. That's what the conditions were like back then. It wasn't our doing. That's what our allies, so to speak, served to us, the Yalta deal. And we landed under the 
Soviet influence. Of course, every immoral action must be condemned, that is, snitching on people, jailing people lawlessly, torture, and so on. But to harass people only because they were PUWP members is, I believe, absolutely inappropriate. (Elbląg, resp. 01)

Our respondents are aware of the differences and, above all, believe that the divisions among Solidarity's former activists are currently deep, if not fundamental. Given this, as shown above, they attempt to produce an unambiguous interpretation of the shared past in terms of the current ideological and political conflicts and divisions. At the same time, effort is made to make the memory of the past capable of sustaining the local community and camaraderie. This is well captured in an interview with an Elbląg respondent whose words vividly describe the situation:

- You know, some of us could [be called] liberal or whatever. We joined the Freedom Union [Unia Wolności]. Some of us stayed away [of the current trade union] at all. Others joined the Centre Agreement [Porozumienie Centrum], so they're radical. And today it looks like that: when we talk, we don't talk about our, well...

- But you still keep in touch, do you?

- Yes, we do, absolutely. I read Wyborcza, and a friend of mine reads Nasz Dziennik. But when it comes to Solidarity and victimised people, we [...] are always on the same page. But when I start to tell him things or he to persuade me, then, no, at this moment we go: thick stroke [laughter]. For either I stop seeing you or you stop seeing me.

- Is that what you say at such moments?

- Yes, it is. Thick stroke. And the unease's over. Because neither will he get me over to his [point of view] nor will I him. But it's not like that when I listen to one of ours out there. No, not really. We've got a few hotheads who, as I told you, would go to the Palace [Presidential Palace in Warsaw]. They would go there. With crosses, and the like things. And some of us have moved on and claim it's the way it should be. That it's good that Poland is free, that it's not in chains [laughter], that it's not anybody's condominium or anything. But others say it is. And they are the same people we worked together with. (Elbląg, November 2010, respondent 04).

Unfortunately, as we continue our research in Poland's other regions, we find that there are areas where people fail to sustain the sense of camaraderie and solidary community in the face of dramatic differences caused by the positions the former trade-unionists take in Poland's conflicted ideological and political structure today. Unlike in Elbląg, in many Polish towns the bonds established in the past have not survived and a deep chasm rifting Solidarity's former members and activists is a sad reality. 


\section{The Crowd, Civil Society and the National Church: The Polish Dispute over the National Symbols and Identity in 2010}

In Poland, the fundamental political conflict and essential social divisions that crisscross people's daily lives involve national identity issues, including questions such as what makes one a Pole (a good Pole, that is) and how the national awareness and interests should be defined in political and social life.

The $30^{\text {th }}$ anniversary of the Gdansk Agreements signed by the striking workers and Poland's communist regime seemed to warrant an exuberant celebration. After all, an overwhelming majority of Poles very positively assessed Poland's post-1989 transformations and the standard of living achieved in its wake. Most Poles harbour no doubts that the collapse of communism and the democratic transition of 1989 would not have happened but for Solidarity.

The celebration, however, did not unfold the way it could reasonably have been expected, and the anniversary occasioned a pointed manifestation of disregard, if not an outright contestation, of the state leaders by the politically partisan trade-union leaders. The symbolic anniversary of the birth of Solidarity showed actually that nothing of the atmosphere that had prevailed in Poland thirty years before had been preserved in Polish society. More than that, the quarrels, insults against statesmen and hostile rhetoric in which the last days of August were steeped were a continuation of the earlier iterations of the social spectacle commenced by what came to be known as the defence of the cross in front of the Presidential Palace in Warsaw. The rhetoric used by prominent trade-unionist of the current Solidarity, $\mathrm{LaO}$ politicians and some of the clergy perfectly dovetailed with the language which was unleashed after the preceding presidential election. Jarosław Kaczyński, the twin brother of Lech Kaczyński, Poland's President who had died in a plane crash, lost the election. In objective terms, his result, i.e. progressing to the second round of the election together with Bronisław Komorowski, a member of the governing Civic Platform and the electoral favourite, was certainly Jarosław Kaczyński’s immense personal success. Prior to the electoral campaign (precipitated by the tragic death of the former President), Kaczyński had been the second least trusted politician in public opinion polls. Despite that, he questioned his rival's victory, saying that Bronisław Komorowski became "President by misunderstanding"! 
The crash of the presidential aircraft stirred extreme emotions in the majority of society. Grieving took a very long time, with the official national period of mourning extending for over a week. (Incidentally, the national mourning in the wake of the 9/11 assault on the WTC in New York took three days.) In a spectacular show of spontaneous social response, people kept gathering in front of the Presidential Palace in Warsaw, flowing in from all over Poland. Up to a moment, the grieving and the manifesting in front of the Palace were indeed a show of national concord and community feelings: though divided and differently minded before, now the entire nation mourned and went through the sorrow of loss together. This formula of the national unity in shared grief was promoted by the fact that the President was accompanied aboard the aircraft by the delegates of not only his own party, i.e. the $\mathrm{LaO}$, but also of all other significant political parties, including the governing $\mathrm{CP}$, representatives of the Catholic Church and other Churches, Polish Army generals and several high ranking state functionaries (e.g. the ombudsman and President of the National Bank of Poland). Soon, a huge, competently crafted cross was placed in front of the Palace, and the scouts appeared and formed a guard of honour around it. Girls and boys wearing scout uniforms took to arranging and having an eye on thousands upon thousands of candles and flower bunches brought along by the mourners. Where they came from is not clear; it would have been logical for the Municipal Guard to continue to see to the order in front of the Palace. Be it as it may, the hosts of reporters swarming at the venue never enquired into that, irrespective of their affiliation. The cross was christened "the scouts' cross," even though it was a riddle how the scouts had become the "proprietors" of the cross. What makes this even more puzzling is that there are two, ideologically divergent scouting organisations in Poland. One of them is the ZHP, i.e. the Związek Harcerstwa Polskiego (Polish Scouting and Guiding Association), which is a continuation of the old and biggest scouting organisation that also operated under the People's Republic of Poland. The other one is the ZHR, i.e. the Związek Harcerstwa Rzeczypospolitej (Scouting Association of the Polish Republic), an organisation of a pronounced national and religious slant, which began to function legally in 1989, initially in a clear opposition to the ZHP. Despite these differences, the media coverage only mentioned "the scouts' cross" as if some young people of an indefinite organisation had taken two planks and nailed them together into a cross in order to manifest their grief and mourning.

This was patently not the case, but how it actually had come to pass was completely obscure and, surprisingly, was not investigated by the media. The scouts appeared again as organisational stakeholders when an agreement was negotiated between the President's Chancellery, the Warsaw Curia and...the 
scouts. The information posted on the Internet said that the agreement had been signed by representatives of both scouting organisations and also the Student Chaplaincy. However, TV news programmes did not offer any coverage of the event. Who brought the cross in front of the Presidential Palace and persuaded the scouts to take care of it remains an enigma. Although this looks like a story cut out for reporters to investigate, Polish journalists seemed peculiarly uninterested in it. Their lack of curiosity is all the more surprising as the issue suggests that somebody deliberately interfered with people's spontaneous manifestations in order to accomplish their specific political agenda, which is blatantly obvious today.

The basic pattern followed by the official media coverage of the events emphasised the shared sorrow, sadness and the recaptured sense of unity in the face of the tragic death of the country's president and prominent political and social figures. Thousands, perhaps even hundreds of thousands, of people heading to the Palace were to symbolise this mourning community. From the very beginning, the media-constructed image of reality had very specific overtones to it, which were amplified in some media while remaining less pronounced in other media. Namely, a symbolic association was suggested between the tragic catastrophe and the reason why the Polish delegation boarded the plane in the first place. The reason for their trip was, of course, to participate in the celebrations of the $70^{\text {th }}$ anniversary of the Katyn massacre, in which the Soviet state had murdered POWs - officers of the Polish Army. What was hardly mentioned in this context (and is becoming specifically significant now) was that the visit of Poland's President with a very numerous delegation representing the entire spectrum of the differentiated Polish socio-political scene was part of an already commenced electoral campaign preceding the presidential election, which was scheduled for the autumn of 2010. The fact that Poland's Prime Minister had earlier gone to Katyn (and also to Smolensk) and met Russian Prime Minister Putin became a very important element of an entirely new definition of the situation which the Radio Maryja has been constructing for a long time and which Jarosław Kaczyński has now joined in constructing, marshalling the strongest, pernicious emotions.

The national-communal definition of the situation in the wake of the air crash did not stay there for long, especially that things were anyway heading to turning the crash victims into martyrs for the Polish cause, or, more specifically, to elevating the deceased President Lech Kaczyński into such a martyr. The process in which Lech Kaczyński was elevated into and glorified as a national hero advanced very fast, culminating in the decision to bury the presidential couple at the Wawel Cathedral, a move that surprised a considerable part of the public. 
The image projected by TV and radio broadcasters did not show the fractures which were caused by the Cracow funeral and the interment of the Kaczyńskis in a crypt close to the Marshal Pisłsudski's tomb. In fact, the communal definition of the situation embodied in the grieving national concord broke down when the decision was made and state agencies began to organise the burial in Cracow. Protests against the Kaczyński funeral at the Wawel only appeared as snapshots in the official media coverage. On the Internet, the most spontaneous and democratic of the media, the developments took a completely different course, soon fledging into an emotional and belligerent spat between the advocates and the opponents of the Wawel burial.

In fact, this more than heralded an important political confrontation of citizens of different beliefs and worldviews. This is my basic thesis: the attempt to turn Lech Kaczyński into a national hero and the way of interpreting the Smolensk plane crash and its implications afford us a unique insight into the essential mental issues Poles are facing today. Let us try to explore what the following events can tell us about Polish society.

\section{Spontaneous or Pre-Programmed?}

Mourning is not reducible to individual responses; mourning is a social duty or at least a symptom of individuals' obligations towards their own group. If every death inspires fear and a sense of group enfeeblement, the deaths involved in the Smolensk catastrophe - deaths of the country's leaders - could not but breed a feeling that the national community and the polity had been dented. This stirred the need for rituals to restore the sense of community to society and to re-invigorate social bonds. This was what we could witness in a crystalclear form. Evolving out of the mourning rituals, the cult of Lech Kaczyński complemented - or was meant to complement - the symbolic reclamation of the sense of community, power and the coherence of the nation and the polity, which had been undermined by the senseless disaster. The process of the social construction of the hero worship - the cult of the tragically (and undeservedly, one could say) deceased President of the Republic of Poland - was very rapid in Poland. The Wawel burial of Lech Kaczyński and his devoted wife was the crowning gesture of these efforts.

At the first glance, this seems a sound analysis. Yet, when scrutinised in a more detached way, distressing ruptures and gaps are revealed. First of all, the social construction of the cult, as analysed by sociologists, did not take a week but, rather, long years. Secondly, formally speaking, if the Wawel tomb attracts institutionally organised pilgrimages of working people who are now assembled 
in the Solidarity trade union, some form of hero worship is indeed in place. The point is that the cult neither did nor does mean that Poles have gained (or, better, regained) the sense of unity and community. If there was any unity and community at all, it fell to pieces as soon as the fateful funeral decision was made. Intended to cement that sense of oneness, the decision bred entirely opposite effects in practice. This is the reason why I have always rejected such an interpretation, even though it indeed helped understand the common and spontaneous response to the catastrophe. However, as we can see, the construction of the hero cult was, in this case, chiefly a calculated ploy rather than an actual social process. The social process could not have developed so quickly. Besides, the moment which once and for all created a symbolic hero through interring him at the Wawel Cathedral immediately split society, and the community disintegrated.

Arguably, the process of constructing the hero worship on the social scale started in fact only when the symbolic cross placed at the site of mourning manifestations became an object of a surprisingly fierce conflict involving politicians, Church dignitaries, reporters and, above all, common citizens. The social battles, or at least the spectacles of the social conflict, at the Presidential Palace bear testimony to a vehement social fight for which values are truly the glue and the vehicle of social bonds and which ones do not deserve that status. The answers to the question whether Lech Kaczyński deserves to be a symbol of the united, national civil society and, as such, a national hero chart the basic axis of the social and now full-blown political conflict. It is not true that the Wawel sepulchre put an end to the conflict for good, because its very idea sparked an overt revolt and dissent in many (if not most) Poles, even as they grieved for the crash victims. The shared sorrow, which was so spectacular that it featured in TV news programmes across the globe, was not enough to re-ignite the community. On the contrary, it engendered an impassioned political, social and cultural conflict.

The intensity of mourning could as a matter of fact be regarded as an indicator of Polish society's everyday frailty as a community. It was a divided, torn and individualised society, a society in which the bonds of daily collaboration and mutual trust were so feeble that it urgently needed shared rituals. For a weak community feels all the more threatened when faced with socially relevant, frightening death.

The events in the wake of the grieving rituals, in particular the political and social conflict around the cross, were a very logical extension of the failed enthronement of a new national hero. And, in fact of something more: of the failed, because brief only, enactment of the social, national and political community. The image of the new national hero constructed in those circumstances 
was practically rejected by an overwhelming part of society despite the official, institutional, state-propped and church-anointed legitimisation of that hero.

Given these developments, the presidential campaign which began immediately after the mourning celebrations is an interesting thing to explore. Jarosław Kaczyński's decision to run in the election was, as it were, a culmination of the efforts to turn Lech Kaczyński into a national hero. Jarosław was, so to speak, the dead president's - emphatically, his twin brother's - successor. Everybody knew that Lech Kaczyński was to have run for re-election. At the same time, the election campaign of Jarosław Kaczyński, who in view of the tragedy could not follow the normal line of action, was informed by the idea that the mourning had essentially reduced the earlier divisions. Importantly, Lech Kaczyński's tenure as president had been deeply marked by his party ideology, as he had unquestioningly and consistently supported the political line of his brother and the Law and Order. As such, his time in office had been a perfect emblem of political divisions in Poland, embodied in his repeated conflicts with the Civic Platform-led cabinet. For this reason, the grieving rituals nearly begged for a communal definition, one of reconciliation among the feuding social and political actors in the face of the deaths of President, LaO leaders and representatives of the entire political arena. Jarosław Kaczyński's presidential campaign was based on the notion that the communal process had indeed taken place, even though very many citizens (and voters) protested against the concerted efforts to make the dead President into a hero. The campaign as such, as well as its style and language, was designed to assuage the public aversion and produce a new image of the twin-candidate as embracing reconciliation and endorsing the value of the newly rebuilt community. The politics of confrontation and constant fighting over who was right and, even more so, who was and was not worthy to represent the common good of Poles and to govern in accordance with the national interest, was supposed to mutate into a democratic politics, in which debate and conflict focused on rational aims and on devising optimal policies.

But when the election day came, bringing Jarosław's defeat (though, as already implied, it was also his personal success), the situation changed drastically. The refusal to accept the democratically elected president and to participate in the secular democratic state rituals immediately overthrew any idea of community. Jarosław Kaczyński contested those rituals, denying them any value, and questioned the legality of democratic procedures. Unsurprisingly, he quickly started to promote emotional political action aimed at re-asserting the hero worship of Lech Kaczyński and the vision of Polishness and the Polish national interest his camp had cultivated. 
Kaczyński's manoeuvres are highly ideological, with a very important issue at stake. The point is that his version of politics concerns the definition of national identity and the way in which Polishness should determine the political order and both domestic and foreign policies.

In the mid-1990s, Claus Offe, a researcher of political transition processes, proposed a typology of fundamental problems post-communist societies were going to face. One of them was national identity, which he viewed as a source of conflicts, not only in the Balkans. When I read his ideas years ago, I thought he was not really right to focus so much on potential conflicts around national issues. Now I admit that Offe's emphasis on these issues was accurate and timely. In fact, the current political conflict in Poland, which is coupled with fundamental social divisions that cut across daily lives of Poles, concerns first and foremost national identity, i.e. what it takes to be a Pole (a good Pole, that is) and how the national awareness and interests should be defined in social and political life. Notably, this issue has never been directly and clearly tackled in public debate, even though it both induces heated emotions and triggers socio-political behaviours.

All this indicates that the attempts to turn the deceased President Kaczyński into a new national hero were a deliberate political move. Certainly, this logically constructed ploy was engineered by political strategists.

\section{The Media, the State and the Church}

Though apparently not only by them. The Catholic Church was another important actor on the stage of social developments. The mourning rituals, as it were, could not have been emptied of a religious component in a society as religiously observant as Poland. The emotions caused by the crash of the presidential aircraft importantly included a kind of metaphysical fear. A sudden and senseless death terrifies because it shows the fragility of individual life and life in this world as such. Consequently, a pressing need is aroused to bestow meaning on such an event, which by default triggers religious thinking as well as fuels religious rituals. In Poland, Catholics are extraordinarily worshipful of the memory of the dead. The great Catholic feast of All Saints' Day has long been turned in Poland into All Souls' Day (or, as the Polish phrase tellingly has it, into Swięto Zmarlych, i.e. the Day of the Dead), becoming a third most important religious holiday after Christmas and Easter. On $1^{\text {st }}$ November, Poles flock to cemeteries, and not to appear on the day at one or another grave of one's close (or, for that matter, not so close) family is, veritably, a disgrace. The behavioural patterns enacted at churchyards on $1^{\text {st }}$ November were effectively 
and spontaneously transposed onto Warsaw's Krakowskie Przedmieście, ${ }^{232}$ with the square in front of the Presidential Palace turning into a symbolic grave, where all the victims, notably the President, were commemorated. Putting up a cross at the site capped, so to speak, the building of a symbolic tomb in the street. The models of the cemetery-to-streets behaviour transfer were already in place, because when Pope John Paul II had died, Poles had put candles and bouquets - funerary symbols as they are - along Warsaw's streets and in Piłsudski Square, where the Pope had read the famous mass. (Of course, when Princess Diana died, flowers were also placed at the gate of London's Buckingham Palace, spilling into the surrounding streets.) The events in Warsaw had a ring of a spontaneous impulse to them as well, yet the religious ritual seemed to prevail. The cross, brought along and given to the scouts, emphasised the sacral nature of mass society's grieving celebrations.

The media, above all TV stations, greatly contributed to creating the symbolism of the site and to legitimising the mourning rituals in progress. All TV stations not only embraced the requirements and rules of the national mourning, but also put up their special studios in front of Warsaw's Presidential Palace. Commercial televisions showed the national mourning footage all days long, too. Had it not been for a considerable uniformity of the broadcasts which focused on constructing and sustaining the sense of social, national and political unity, it would have been impossible to achieve the aim of turning President Kaczyński into a national hero.

But all this took the input from the Catholic Church as well. Generally, the situation showed how thoroughly the state rituals were permeated with religious patterns and church rites. The secular state ritual proved too modest and was quickly brought in alignment with to the rules of ecclesiastical mourning rituals. Much of the conduct displayed by the mourners, e.g. kneeling in front of the victims' coffins, was religiously unwarranted. Still, the composite image produced in the first days of mourning emphatically showed the social power of Catholicism and the model-setting impact of the Church. Unsurprisingly, the ecclesiastical hierarchs started to play an increasingly important role in the grieving celebrations. The decision made by Cardinal Stanisław Dziwisz, Archbishop of Cracow, crowned the national sanctification of President

232 Krakowskie Przedmieście is one of Warsaw main avenues. Centrally located, it is the address of several important institutions, including the Presidential Palace. (translator's note) 
Kaczyński. ${ }^{233}$ At the same time, it spurred sharp social protests, also among Catholics, who are an overwhelming majority of the Polish population.

The decision had also clear political implications and marked the beginning of the Church's later involvement in the political process, an involvement so pronounced that it reminded of the first years of Poland's democratic transition. The fight for the cross at the Presidential Palace showed how pivotal the engagement of many influential bishops was (though it had been obvious in the earlier electoral campaign as well). The lessons from the Church's previous direct involvement in election campaigns, resulting above all in the sharp decline of social support in 1993, had clearly been learnt. The Church dignitaries were now cautious not to express their political support too overtly. Admittedly, some influential priests endeavoured to participate in political processes, e.g. in constructing the coalition government, but these attempts were not very successful and always triggered sharp public responses. Also, for a long time, the Church purpurates did not comment on the conflict between the two major non-communist parties. Arguably, it was not necessary to comment as the bishops fully consciously supported the Radio Maryja with its very lucid political and ideological message. Since its foundation, the Radio Maryja had embraced the national-and-Catholic position and formulated a politically-inflected worldview, tackling matters far beyond the purely religious concerns. The Radio emphatically used values defined as Catholic and Christian to forge a very clearly delineated national political awareness. It certainly was, and still is, an attempt to update and modernise the ideological notion of the Pole as a Catholic.

Drawing on the old tradition as it did, the worldview crafted by the Radio's Director and his team certainly did not just reproduce that tradition. Rather, it retained the structure of beliefs and ideological images analogous to the National Democracy's mindset and ideology. Analogous was also the Radio's definition of politics as geared to making Poland a significant state in Europe in the semblance of the National Democracy's aspiration to make Poland a sovereign state, a goal achieved in 1989 as unexpectedly as in 1918. Additionally, the Polish state was supposed to express religious values defined by the Catholic nation. Politics propagated by the Radio Maryja is, unchangeably, nationally inflected, and only this national slant really matters. And as national equals Catholic, the merger of the national and the Catholic (and, consequently, the ecclesiastic) thinking and

233 "The decision" here refers to the decision to have President Kaczyński and his wife buried at the Wawel Cathedral. (translator's note) 
rituals forms an inextricable and inviolable symbolic whole. This produces a very sharply delineated version of the national Church.

Another important aspect is sectarianism of the Radio and its listeners. Father Rydzyk, the Radio's Director, has managed to construct a new social identity: the community of the Radio Maryja listeners. Since this identity and community (called the Radio Maryja Family) crystallised, the Catholic Radio has explicitly shaped sensu stricte political attitudes. Without Father Rydzyk's backing, Roman Giertych, a radical continuator of the National Democracy line, would have stood a very slim chance of getting a seat in parliament. The support from the Radio Maryja changed his niche party into a parliamentary grouping. ${ }^{234}$ Lech Kaczyński’s electoral success was also considerably channelled by the Radio Maryja backing. The Radio and its accessory media launched by Father Rydzyk became a platform for the $\mathrm{LaO}$ politicians when the party was the Radio's cherished item. It was the mindset of the Radio Maryja listeners that had made President Lech Kaczyński into a representative of national and Catholic interests, long before his tragic death in the plane crash.

Previously, however, the criticism of the Radio and its Catholic "politics" in a way allowed neglecting its impact. Also, within the Church itself, controversy was rife about the position and interpretation of the message propagated by the Radio Maryja. Apparently, the Smolensk catastrophe helped the Radio Maryja advocates and supporters gain advantage in the Polish Episcopate and, generally, among the bishops. This is at least how the Warsaw cross events can be interpreted.

The agreement signed by the President's Chancellery, the two scouting associations, the Student Chaplaincy and the Warsaw Curia was totally ignored by the people who came to be called defenders of the cross. In a brief, yet violent, affray at the cross, the priests and officials who had come to execute the will of the state and the local bishop were assaulted. This, I believe, is deeply meaningful and consequential ${ }^{235}$ because the fundamentalist national Catholics completely disregarded the decisions of the Catholic bishop which should have been binding for them. Moreover, they did so in the name of a purely secular, rather than religious, political venture.

234 The party was the Liga Polskich Rodzin - the League of Polish Families. (translator's note)

235 On $16^{\text {th }}$ September 2010, the cross was transferred from the square before the Presidential Palace inside, to the Palace's chapel. Ultimately, it was placed in the Loreto Chapel of St. Anna’s Church in Warsaw. 
I have no doubts whatsoever that the people who were gathered and mobilised to, as they put it themselves, defend the cross were shaped by and subscribed to the religious-cum- national ideology of the Radio Maryja.

The fight for the cross evolved into a struggle for a total acceptance of the national hero worship of Lech Kaczyński and, as such, into an attempt to enforce the universal endorsement of the idea of the nation and national politics as defined in national Catholicism. The conflict around the cross was a complex and polyvalent development as constructing the hero cult was only a vehicle of multiple meanings. The meanings concern, first, the contents of national awareness; second, an operationalised way of defining the national interest; third, the place and function of religion and the Catholic Church in politics and the state (what is the Church supposed to be today?); fourth, the role, duties and obligations of the independent state towards the nation; fifth, the relationship between the thus-defined political nation and society as a whole. This invites several questions, for example, about the extent to which the Catholic values, as the most commonly (formally at least) endorsed values, can be used as a basic symbolic resource and the cornerstone of the state. Briefly, in how far must citizenship mean the guarding of the religious values of Catholicism?

\section{The Church, Polish Catholicism and Civil Religion}

At the moment, the place and the relevance of religion in Polish politics are a highly paradoxical issue. I believe that the Church has been explicitly politicised, and the bishops have been lured by the power and pertinence of religious rituals in society's spontaneous mourning behaviours. These behaviours have been construed as re-asserting the notion of the Catholic Church's strength and power over the social imaginary and conduct, observable in the national mourning. Despite all possible (and serious) theological and intellectual reservations, the strength of Polish Catholicism can hardly be doubted. The religious investment in collective behaviours and social manifestations and rituals is deeply associated with the role the Church played under communism in Poland. Without the Church, Polish society could have hardly stood up for freedom and independence. The intertwining of the democratic opposition's goals and the Church's teaching promoting human and civil rights in the late 1970s bore unusual fruit in the form of the Solidarity social movement. The word "solidarity" itself became an internationally recognisable slogan of the non-violence movement that sought to achieve social goals. Consequently, whatever their response to the Catholic Church's post-1989, hardly democratic political and social demands, Poles are still grateful to the Church. In the dark decade of the 1980s, when 
Poland's communist regime waged a war on its own society, the Catholic Church was a mainstay of citizenship, liberty, independent thought, art and culture. Without this kind of backing, and without the Church's deliberate policy of support for society, Solidarity's victory and the surprising effect of its activity - the collapse of the regime in Poland and the rapid crumbling of the USSR power would hardly have been imaginable. Hence it does not come as a surprise that the function, significance and rootedness of the Church and its rituals, as well as the role of the Catholic clergy in daily life, are so fundamental and indeed unquestionable. Admittedly, the institutional Church has always taken advantage of this social position, sometimes infracting the democratic, legally instituted rules.

To define the relevance and social functions of religiosity in Poland, we can usefully resort to the notion of civil religion. The concept helps distinguish the national religion from the institutional denomination, no matter how tightly the two are interconnected. For the US, Robert Bellah argued that this kind of religion included beliefs that framed various features of the American nation as sacred and demanded that the civil nation submit to the ethical principles that conferred transcendence on the earthly order. This is basically what happened in Poland in the 1980s. The Catholic Church and simply church buildings chronically played a double role as places of the common Roman Catholic worship and as sites of the national and civil mobilisation of Poles under the official patronage of the ecclesiastical institution. This afforded opportunities of resistance and empowered society's freedom aspirations.

Paradoxically, now we can clearly see the ramifications of that civil religion, especially when the universal Catholic Church excessively expresses the political will and frames itself still as the nation's representative despite, or even against, the democratic state and its democratic institutions. As a result, the civil religion of the 1980s is turning into an ideological and political faction, while the Church in Poland is becoming a party-like political actor.

The consequences of these developments may indeed be interesting since the distressingly clear-cut and unbending position of the bishops must at a certain moment clash with the attitudes of the majority of citizens, who are at the same time Catholics and form the Church's congregation. The events in front of the Presidential Palace and a lack of any clear reaction to the explicit dismissal of the ecclesiastical decisions imply that the institutional Church finds itself in an utter confusion and an inner impasse. Frankly speaking, Polish religiosity has long been known to be differentiated and internally conflicted, while the way in which the institutional Church has nestled itself in Poland's democratic and hastily democratising society is likely to trigger even more disputes and conflicts. The style of the Polish clergy, who look down on the faithful and harshly 
admonish them - a style in which moral models and interpretations of moral dilemmas, proliferating in modern societies as they are, are imposed without any debate or discussion - must sooner or later stir negative responses. In the long run, it is impossible to maintain the absolute and aloof power of vicars and bishops, who do not allow any discussion, not even any exchange of views within Catholic communities. A democratic society which pursues increasingly better education will not put up with such authoritarian patronising for much longer. This is the likely site of the first clash with national Catholicism, which embodies not so much conservative as rather traditionalist customs, norms and moral definitions, which it will be ever more difficult to reconcile with the democratic, open and human rights-championing mindsets. 



\section{Mourning as a Significant Social Fact}

Antoni Sułek discussed, first at meetings at the Department of Sociology and then in a paper, ${ }^{236}$ collective behaviours observed in the wake of the Smolensk catastrophe, drawing in his conclusions on Émile Durkheim's insights. As a result of extensive media coverage, Warsaw’s Krakowskie Przedmieście, where people spontaneously assembled after the fateful plane crash, quickly acquired symbolic meanings. Krakowskie Przedmieście became the focus of international media and as such attracted enormous attention in and outside Poland. Following Durkheim, Sułek argued that what was going on in front of the Presidential Palace was an expression of the fundamental meaning of mourning: the social actions served to re-build the sense of bonding, stability and unity in the disasterstricken national group.

Mourning is well known to have a unifying function. Funerals are concluded with a special ceremony: the wake attended by all mourners. The gatherings in front of the Presidential Palace in the aftermath of the Smolensk catastrophe served as spontaneous, communal mourning rites.

Of course, describing those past events we should not overlook the role that the media played in producing the symbolism of the venue in front of the Presidential Palace, both the office and the dwelling of Poland's President who had died in the plane crash. It was not surprising that people spontaneously assembled there. However, from the very beginning, the site was an arena not only of spontaneous impulses but also of entirely deliberate political and organisational manoeuvres. The media, in particular TV coverage, fashioned an official framework of the events from before the Palace and at the same time invested them with specific meanings: in the media rendering, the mourning restored the sense of community, overriding all previous divisions among Poles. TV broadcasts added thus special trappings to the spontaneous and pre-planned social actions. The very presence of TV cameras at the site (and indeed, the reporters hardly ever left the place) inclined people to more or less consciously stylise their behaviours in order to affect the internationally transmitted image of Krakowskie Przedmieście. The presence of an array of TV stations and networks produced an official stage on which to manifest grief. The spontaneous behaviours rapidly mutated into a social spectacle.

236 Antoni Sułek, “Wielcy socjologowie a śmierć prezydenta," Więź 8/9, 2011. 
Independently of TV coverage, another, unofficial stage was emerging on the Internet. The initially exhibited sense of community was, in my view, very quickly dispersed. The decision to have the President and his wife buried at the Wawel Cathedral immediately divided what the mourning had just forged into a unified, national, Polish society.

Consequently, there were two stages on which the mourning celebrations went on. The official one included Krakowskie Przedmieście, continually shown by all TV stations, which by the same token participated in the national mourning rites, making them accessible to their viewers. The other one, developing on the Internet, painted a completely different picture than the image disseminated on $\mathrm{TV}$, especially towards the end of the official mourning period. On the Internet, a veritable war burst out between the advocates and the opponents of the Wawel burial. War is an apt term, indeed, for basically all online discussions were steeped in an extraordinarily virulent language, quite unbecoming the circumstances. In retrospect, we can conclude that if there was any shared, communal manifestation of mourning at all, it only took place in the first days after the catastrophe.

I do not think that those April days ${ }^{237}$ told us anything new about Polish society. But I believe that they did bring out some noteworthy issues. Looking at the patterns of Poles' electoral preferences following the events, we can see that they are rooted in a very important conflict which, in my view, underlies the current political dispute between the Law and Order and the Civic Platform. The conflict concerns national identity and awareness, an issue as important as it has been latent in our discourse so far. It shows most clearly in the choice of the symbolic embellishments to accompany the representation of collective feelings and meanings. In my view, it is one of the fundamental Polish conflicts, and it has both a cultural dimension and a political dimension to it. In this context, it concerns above all the way of understanding and defining national interests in the modern world and modern Europe.

Over time, the ensemble of representations shared by the advocates of the Kaczyńskis' burial at the Wawel Cathedral developed into what is now referred to as the Smolensk myth. The emergence and consolidation of the Smolensk myth as a rather permanent set of beliefs, including political beliefs, are evidence of the profound enrootment of the conflict around cultural identity and the models of experiencing Polishness involved in it. Additionally, these models are translatable into two different visions of politics.

237 The presidential aircraft crashed at Smolensk on $10^{\text {th }}$ April 2010. (translator's note) 
One of them is a pragmatic vision of politics. In this framework, the responsibility of the state is to prevent various problems, for example, by forbidding housing construction in areas which get flooded when the water level goes up in rivers (in circumstances less dramatic than the disastrous flood that devastated Poland in 2010). Goals set in this kind of politics are realistic and achievable within defined time-frames. While its aspiration is to strengthen and develop both the state and society, it does not overlook the international partners and engages in transactions with them so as to boost the country's growth. The citizens' prosperity is the politicians' supreme aim.

This pragmatic vision is opposed by the model of politics based on preaching Poland's greatness and constantly emphasising the Polish interest, which must necessarily originate and be rooted in Polish tradition. The fundamental aim of this politics is safeguarding the national tradition and whatever results from it now. In practice, this means turning away from the entire world. Depending on the call of the moment, everybody is evil: Russia, Germany and, of course, the European Union.

In this model of politics, Polishness is constituted by strictly defined, permanent national values, which are incompatible with the modern world. The world - Europe in particular - tends to refuse to recognise them (some of them at least), which cannot possibly be condoned. Given this, the only possible and appropriate way for Polish diplomacy to communicate with others with Germans, Russians, Europeans, etc. - is "putting our foot down.," and that not even metaphorically speaking. This species of politics takes it for granted that Poles as a nation and consequently the Polish state have a unique historical calling. In national ideology, the national values bear a universal moral message. Unsurprisingly, the national values are believed to command recognition and respect of other nations and obviously of the states that represent these nations. Consequently, the responsibility of politics and diplomacy is to constantly remind others of those values and demand heeding them.

Of course, this vision of national politics is grounded in and refers to the national-Catholic tradition of Poland. It was also poignantly visible in the period of mourning following $10^{\text {th }}$ April. This vision attributes a special role to the Catholic Church, which very skilfully joined the political game played in the aftermath of the Smolensk tragedy, both during the mourning celebrations and, later, during the presidential election campaign, which was precipitated by the death of the President of the Republic of Poland in the fatal crash. People of the Church got astonishingly deeply engaged in the election. I guess a comparable situation last took place in Poland in 1993.

This issue is linked to the national identification of Poles. Kinga LachowiczTabaczek and Beata Pachnowska have found in their research that Poles' 
identification with the nation is very strong in comparison with other European countries, such as the UK, Holland, Italy and Germany. For a considerable proportion of Polish society, the statement "I am Polish" is a very important element of not only national but also personal identity. Only Italians scored similarly in the study, meaning that Italians very strongly identified with their nation. Yet Poles significantly differed from Italians in terms of a very strong differentiation within the national group. Specifically, while identifying very closely with the nation as such, Poles tended to exclude some people from it, believing that not all Poles are true Poles. A very considerable part of the sample agreed with the statement "I cannot generally identify with all Poles because there are always some bad Poles." The feeling of internal division makes us unwilling to accept in-group differentiation, and we have no framework that holds the whole together over differences.

My reference to Italy is not random. Living in a unified country and one state is more of an exception than a durable historical experience for Italians. What is now Italy evolved from a collection of highly varied political and cultural traditions, which were united into one nation-state not a long time ago. This notwithstanding, the sense of national identification with other compatriots is far stronger in Italy than it is in Poland. Italians do not seem to have a problem with national unity despite deep-running historical differences.

These findings overlap with the stereotype that Poles are able to unite and collaborate effectively when faced with crises and/or external threats, yet they are unable to cooperate in peace, a belief often cited in the context of the events following $10^{\text {th }}$ April. At any rate, the "Smolensk myth" is nothing else than a manifestation of the "true" Poles against all others who do not deserve this name, a manifestation conserved and perpetuated in the political agenda. The spontaneous and institutional efforts following the Smolensk catastrophe and aimed at uniting the civil and national community produced in fact a deep rift dividing Poles into the "true" ones and a non-national rest. Or it is at least what a small, albeit significant, part of society believe to be true.

This state of affairs, which has only exacerbated over the years since the Smolensk air crash, is a dramatic negation of the basic experience of Solidarity. And yet it is difficult to imagine the collapse of the People's Republic of Poland and the entire Soviet system without Solidarity. Even if preserved in the memory of the millions of its participants, the experience of the Solidarity movement does not seem to help establish any kind of community above divisions. On the contrary, the trade union, which still underscores its continuous activity across the 1980s and up to the present moment, has become a social and national actor that contributes to deepening the split within the Polish nation. 


\section{Peace as a Method of Social Action: The Path of Polish Solidarity}

Let me start with a personal remark. It seemed paradoxical to me to write about peace in the context of memory, an exceptional context concerning the vast movement of Solidarity, which laid the foundation for modern, free and democratic Poland. Throughout my young years, especially when I went to school in Gdansk, I was daily exposed to peace slogans and bombarded with the symbols of peace, for which socialism fought with so much aggression under Gomułka and with equal adamancy, though less belligerence, under Gierek. Such words as "peace" and "the fight for peace" were on everybody's lips, rehearsed on every occasion, while flocks of doves of peace, drawn once by Picasso, hovered over our heads at school and outside it. Back then, "peace" was exceptionally ruthless, not to say ferocious, in its peaceable [!] rhetoric. It was like the huge, clenched fist of the "leading system" that menaced the world.

However, the word "peace" did not surrender and came back with enormous power as the Gierek era drew to its end and a new consciousness was germinating in Poland. First, the rise of the democratic opposition (with the KOR as its first organisation) and, later, the teachings of the Polish Pope John Paul II encouraged "demanding what's due to us" - that is, the rights of man and the citizen - by peaceable methods. The idea of a non-violent struggle for human rights against the violence of the party-state was being forged in reflection on the remote and recent past.

The year 1970 was that recent past which was remembered mainly in the TriCity and Szczecin. The memories of the vile, bloody crackdown on the protesting shipworkers executed by the government, which posed as the "workers' government," were very vivid. Those memories taught people to take all precautions against another betrayal by the people's government (as the communist authorities referred to themselves) dedicated to "fighting for peace," a government that had never hesitated to institute "peace" by violence over the dead bodies of its own citizens.

The remote past was a past of the Second World War, notably of the defeat in September 1939 and the fall of the Warsaw Uprising, so tragically consequential for Poland. The Uprising experience was particularly traumatic, as it took the toll of several hundred thousand lives and robbed Polish society of a huge part of its elite, leaving the surviving part paralysed by distress and the sense of failure. 
All this was on the minds of people who organised and joined the protests in 1979 and 1980. The shipworkers, followed by masses of other employees, arranged the protests so as to force the regime to negotiate, in full awareness that any direct confrontation would have a dire end for the protesters, because the regime's advantage was overwhelming. As a result, people consistently and pointedly chose peaceable protest methods and claims. This peaceable approach to demanding that the government respect the rights of man and the employee was, in a sense, an effect of rational calculation: to provoke the powerful opponent to resort to violence simply did not make much sense. Such was the basic lesson of the December'70 events. It taught that violence posed a lethal threat to people and trampled all demands, no matter how morally sublime they might be. At the same time, the regime on which demands were laid continually perorated about "humanistic values", which it allegedly made a reality with incomparably more effectiveness than "(morally) degenerate capitalism" did. The government could not entirely give up on its flowery verbiage if the protesters used a similar language... Consequently, it only made sense to talk insistently, using the humanistic language without provoking the regime.

The firm resolve not to oppose the government in any forceful way and not to respond to the regime's provocations had also other roots and implications. I believe that it resulted from a re-making of the Polish model of fighting for the right cause and values. My reference to the memory of the Second World War (in September 1939 we declared we would not surrender a single button off the Polish army uniform) and the Warsaw Uprising was by no means gratuitous. I deeply believe that popular consciousness - the consciousness of a democratic people, to use the grandiloquent term - drew conclusions from Poland's history, in which fight as a rule entailed self-destruction and failure in the name of higher values. The years of the communist oppression and the violence-founded regime reinforced by the power of the USSR also taught that the policy of small steps and toilsome pressures could persuade even an omnipotent opponent to offer some concessions. At the same time, people were beginning to think that failure was simply failure, and whatever ennobling sense was attributed to it, the losses it incurred and the painful price to be paid for it would not be reduced. The crucial element of national symbolism, in which failure in the name of superior goals and universal values was paraded as a spiritual victory, fortunately stopped appealing first to the founders of the democratic opposition and the leaders of workers' protests as well as, later, to the organisers of the Independent Self-Governing Trade Union "Solidarity." The recent experiences made people re-assess the heroic history of Polish martyrdom and relinquish the earlier model of struggle for a higher cause, in which an opponent against whom victory was 
entirely impossible was taken on without any calculation of odds but, instead, with an enthusiasm fuelled by moral reasons and noble, universal goals.

The peaceable movement, which ultimately swept off the face of the earth the germ of a new totalitarian civilisation purportedly created "in man's name," chose the most effective method possible. One reason behind its efficacy was that the "peaceable" world of socialism and communism was entirely unprepared for such tactics. In its fight for peace, communism was basically a warring movement, in which the conquest of the world in the name of the right idea was the main engine and motive of action. A belligerent approach always demands simplified definitions of the situation which determine the most important interests, goals, strategies and tactics. This simplification involves distrust, expects subterfuges on the part of the opponent and ineffectiveness of the allies, presumes the necessity of scheming and ruses, insists on constant control and demands keeping at least current aims and action plans secret. The fight necessitates rejecting, or at least limiting, openness, even among the allies, who are never believed to be consistently uniform and unanimous. By default, war cannot be fair, and the belligerent approach itself precludes transparency and sincerity, as already mentioned.

A truly peaceable struggle, justified by its proclaimed goal, is different. There is nothing to hide, because the aim of changing reality is not only a symbol but also an essential demand in the name of which action is launched in the first place. Peace requires collaboration, collaboration and above all collaboration, even in competition, just like sports events need referees or umpires to assess whether the contestants abide by fair play rules. Peace is truthful.

This, however, does not mean that peace equals quiet! Just the other way round, peaceable action and peaceable collaboration must cause a terrible din: fists and blows are replaced by words, which seek both to drown other words and to tune in with them in sync. The daily reality is engulfed in the cacophony of discussions and negotiations, but this jarring tends to mutate into a sonorous harmony that alloys voices and behaviours into unified collective action.

Peace is predicated on and enforces honesty and openness. Openness means on the one hand a clear articulation of motives, goals and expectations involved in action and, on the other, a capacity to listen to others and understand their motivations, desires and fears which may be triggered by our declarations, plans and conduct. Solidarity's peaceable movement had no reasons to conceal its fundamental desires that swayed millions of people to get engaged in joint action. The solidary community proved a force with which violence had to negotiate. The Solidarity movement laid simple and fundamental, truly elementary claims, demanding that society and citizens have their own organisation to express their 
interests, to fight for their rights and to make the state equitably apply its laws to all citizens.

Today, however, research on social memory shows that an overwhelming majority of the then-solidary Poles remember the peaceable movement as pursuing clearly political goals, with independence being the most important of them.

\section{CBOS. ${ }^{a}$ What do you think was the most important element in the} Solidarity movement in the period 1980-1981?

Efforts to make Poland a free country $57 \%$

Fight for people's freedom and civil liberties $49 \%$

Fight for equal rights and equal treatment for all citizens in Poland $40 \%$ Efforts to ensure decent working conditions and wages for workers $39 \%$ Generally, attempts to make life better for people in Poland $34 \%$ People's attempts to be able to control the authorities and influence $18 \%$ important decision-making Desire to restore traditional national and religious values to their $\quad 12 \%$ rightful place in Poland

Something else $1 \%$ It's difficult to say $5 \%$

Beata Rogulska, Ocena historycznego znaczenia NSZZ "Solidarność." Komunikat $z$ badan. (Assessment of the Historical Relevance of the NSZZ "Solidarity": Research Report) (CBOS BS/72/2010, p. 15).

${ }^{a} \mathrm{CBOS}$ is the acronym for the Centrum Badania Opinii Publicznej, i.e. the Centre for Public Opinion Research. (translator's note)

\section{The study on Doświadczenie i pamięć Solidarności (Solidarity: Experience and Memory), carried out by the European Solidarity Centre, the Centre for Public Opinion Research and the University of Warsaw, led by Ireneusz Krzemiński, 2010. Quotation from an interview:}

[The year] '76. It was one more example showing that all they could do was throw [a beating] on people. [Before] I'd gone through '70 and seen them shoot people. And I'd been through [the year] ' 68 . But that's the way I've always been: yes to socialism, no to distortions. I knew that things would be rough, that there'd be protests [...]. What happened in ' 80 , I mean that the guys, and first of all the girls, blocked the gates and said "No one's going out," was to prevent the year '70 from repeating. And because of the memory of the year ' 70 , in ' 80 there was basically no problem with taking to the streets, because our basic doctrine was that we stayed put at the shipyard and they had to come over to us... (Gdansk) 
However, such a demand and such a goal were not announced at the time, at least not when the leaders and members of the NSZZ "Solidarity" articulated their aims and engaged in debates and negotiations with the authorities, or rather with the regime. Where were the openness and candour of the social movement assembling ten million people back then? Is peace by any chance misrepresented in the description provided above?

I argue that it is not, because openness and candour indeed mean being able to explicitly and openly dispute and reveal, also amidst one's allies, different visions of future actions, goals and motivations. Solidarity's peaceable movement, as any other huge social undertaking, was not homogeneous in that it accommodated and expressed various desires, motives and aims. After all, it had developed from scratch, evolved from bottom-up activities - as the popular phrase went back then - and, as such, pursued different goals at different enterprises, factories and offices. It formulated different goals at the regional level and within various industries as well (Poland's economy under Gierek was organised in industry branches). The movement had also its, so to speak, "official" core mainstream of shared, commonly defined goals. One of the strategies of collective action involved presenting those goals and negotiating with the government how, if at all, they could be pursued in the realities of the state and the country by changing practical legal and institutional regulations. At the same time, in dozens of voivodships (provinces), concrete issues were negotiated with voivodship (provincial) governments, even though it was becoming increasingly clear that local bargaining did not matter much and could at any moment be marred or revoked through an interference of an upper agency. This made people realise that peaceable struggle was arduous and prolonged, that it might "squander strength" every now and then but that, in return, it was not stained with the blood of victims.

The peaceable way is all the more wearisome because it presupposes that within one faction people can have various views and launch various initiatives. The method also showed that those who endorsed negotiations and debating, rather than a warring confrontation, could be expected to differ widely. War demands special discipline, which forestalls all discussion and private initiative. Peaceable social struggle, on the contrary, proceeds from debate to debate, from negotiation to negotiation. The peaceable method adopted by the government in August 1980 required the same approach; unsurprisingly, the governmental delegations from Gdansk and Szczecin time and again headed to their headquarters to negotiate and agree on the successive stages of bargaining. 


\section{CBOS. Why did you decide to join the strikes in 1980-1981?}

I thought it was time to start fighting for working people's rights and 54\% interests.

Everybody else around wanted to go on strike, so I joined them. $\quad 44 \%$ I wanted to fight for free and independent Poland. $38 \%$

I felt solidarity with other enterprises on strike. $\quad 37 \%$

I thought the wages-related demands were sound and wanted better 32\% living conditions.

I wanted to contribute to changing the system gradually. $20 \%$

I was spurred by my family's cultivation of national independence $\quad 6 \%$ traditions.

Other reasons

$2 \%$

Michał Strzeszewski, Doświadczenia z okresu "pierwszej” Solidarności. Komunikat $z$ badań (Experiences of the "First" Solidarity Period: Research Report) (CBOS BS/87/2010, p. 9)

\begin{tabular}{lll}
\hline $\begin{array}{l}\text { Categories of answers } \\
\text { to the question about } \\
\text { trade-union meetings }\end{array}$ & $\begin{array}{l}\text { Memory of general } \\
\text { trade-union meetings } \\
\mathbf{N}=\mathbf{3 2 0}(\mathbf{\%})\end{array}$ & $\begin{array}{l}\text { Memory of meetings in } \\
\text { your organisation N=14 } \\
(\%)\end{array}$ \\
\hline $\begin{array}{l}\text { Yes, there were regular } \\
\text { meetings. }\end{array}$ & 31.3 & 22.6 \\
$\begin{array}{l}\text { Yes, I remember that we } \\
\text { had general trade-union } \\
\text { meetings from time to }\end{array}$ & 39.0 & 48.7 \\
$\begin{array}{l}\text { time. } \\
\text { I don't remember any } \\
\text { general meetings of the } \\
\text { trade-union unit }\end{array}$ & 28.9 & \\
No answer & 0.8 & 22.6 \\
\hline
\end{tabular}

Doświadczenie i pamięć Solidarności (Solidarity: Experience and Memory), European Solidarity Centre, Gdansk 2010. 


\section{The study Doświadczenie i pamięć Solidarności (Solidarity: Experience and Memory), 2010. Quotations from interviews:}

1. As one Gdansk respondent said: "In that period, it was like, as the phrase went, a gust from the sea, of that freedom, liberty, sense of security, feeling that we were free. That somehow nobody controls us, we could freely speak our minds, though it wasn't [for] long."

2. "A lot of journalists [use this phrase], I have a request, no carnival, please, look up in the encyclopaedia what carnival means. [In Solidarity] it was hard, creative work" (Tri-City).

3. 'I remember, $w$ attended such regular 'roundups' - these meetings were very lively, because we talked not only about how to set up a trade union, to collect declarations, etc. A public forum arose there right away, discussions about most diverse themes were rife. In this way, leaders emerged, because people who had the gift of the gab immediately appeared as good candidates to elect. They were immediately elected for various positions, to be leaders" (FGI, Bydgoszcz/Toruń).

4. A Solidarity member from Poznan: "You could be fully yourself. You didn't have to pretend anything, didn't have to sell yourself to gain something."

Still, peaceable struggle and peaceable action cannot be naïve. If Poles gave up the belligerent way of obtaining important goals for society and the nation, they did so because they recognised the peaceable way as more efficacious. Importantly, peace in social action demands discipline as well. Mentioned above, the din of voices in which shared positions are established must not transform into a chaos of actions once decisions are made. Peaceable action requires discipline, yet this discipline differs from the discipline of warfare. The peaceable discipline is informed by the idea that all people involved in action make the common goal their own, private goal and feel responsible for it the way a parent feels responsible for the child, i.e. not in general terms but at every moment of the day. Given this, the discipline of peaceable action allows a bit more freedom of individual initiatives for the sake of streamlining the achievement of the common goal.

Discipline also showed in joint action in another way. Effective action had to avoid provoking the government, which had chosen to follow an unfamiliar path it had not trodden before: a path of debate, negotiation and agreement. In such circumstances, if common goals were to be achieved and people's lives protected, it was imperative not to prod the insecure opponent, who was ready to put the machinery of violence and war in motion at any moment. In this huge theatre of bargaining, it did not make a lot of sense to openly make demands which the other negotiating party considered unrealistic and did not even conceptualise. 
As a result, a new kind of discipline was established which prevented voicing - at least not during the key negotiations - the dreams and desires which only irked the opponent into adverse reactions.

Let me return to our previous observation about the choice to give up the bloody, heroic gesture for the sake of the arduous toil of negotiations and incremental, yet bloodless progress. As I see it, the discipline of prudent demands and unspectacular steps merges with this choice into sound judgment, a judgment which does not erect the order of the heart into the only, apodictic, indisputable imperative. Sound judgment understands morality as the toil of everydayness, values every human life and as such must act so as not to enforce heroism or "the gift of the blood."

At this point, another property of the peaceable struggle method appears as a piece completing this jig-saw puzzle. Freedom is this property, meaning that people involved in common action are free to speak out, to propose things to do, to group in various configurations and to be separate social actors, each having their own voice. Indeed, Solidarity's peaceable struggle messed up the previously homogeneous sector of power. The group of power-wielders started to differentiate as well, demanding individual freedom of expression and implementing (not for long though) a considerable freedom of debate (i.e. empowering the horizontal structures within the PUWP).

I believe it was then the regime of the "leading system" came to regard that the peaceable method of fighting for social and national goals as very hazardous. The peaceable method relied on discussion, debate and negotiation, which not only demanded relinquishing force and violence, but also produced a new quality in social life, whether people's allegiance lay with one crucial political actor or with the other. The new quality involved an eagerness to speak out, voice one's views and discuss things. It was, so to speak, people's keenness to compare their ideas, to search for the best means of expression, to agree on and, then, to make a thing happen. Such a desire is, as it were, one of the deepest human desires. The wish to shine, to garner recognition, admiration and prestige, to enjoy authority and to be heeded by others is intrinsic to human social life. In peace, such yearnings can be satisfied through words and articulations in public rather than through battling and war. Debate, no matter how objective and to-the-point, affords ample opportunities for individual shows, self-presentations and proposals of varied pathways of goal-achievement. Appearing in public is always a chance for individuals, especially when the stage they enter is discussion rather than combat.

The stage of discussion is extremely dynamic and confers meaning and relevance on people, groupings and factions... It leaves people no other option but 
to reveal, so to speak, their own face, judgments and views, which are not anonymous but belong to a specific individual who is accountable for them. Peace in society makes people into individuals and, consequently, differentiates a coherent collective... The community must repeatedly re-establish and re-assert itself, forever remaining heterogeneous and unstable as some matters breed unanimity, while other ones divide people and permanently preclude any uniform approach. The "collective" camp finds all this an unacceptable scandal! Consequently, the peaceable communist camp soon had to counteract such individualising and freedom-sowing developments.

This is not where the notions of the "peaceable struggle" or the "peaceable road to social goal-achievement" arrived at their end. When General Jaruzelski's regime declared war on its own society and nation, a new model of social action emerged very quickly. The military, warfare-like methods were again rejected with utmost determination. The former way of accomplishing peace turned out to be unacceptable to the "peaceable" government. Violence annihilated the forum of debate, discussion and negotiation. Nevertheless, society did not relinquish its peaceable mindset. Its more active portion continued practical civic activities, despite the punishments they faced. And a considerable part of society, while not up to a more heroic conduct, adopted another method by choosing to struggle peaceably through dissent, through refusing support and through withdrawing from whatever the now militarised regime proposed and cajoled people to do. As life had to continue, people did what they had to do, but slowed down and only performed the necessary minimum of their duties. Everyday dissent also consisted in denying any trust to the "peaceable" power of real socialism. Nobody gave ear to what the government said anymore, particularly when attempts were made to persuade and mobilise people to undertake one activity or another. Admittedly, the regime grew ever more omnipotent, put opposition activists to jail one by one and chased people away from the social niches of engaged communities. To no avail, however. Nothing seemed capable of stimulating people to come up with initiatives and to work better, more efficiently and more creatively. Whatever creative and/or productive action was undertaken, it was only pursued outside the state's institutions, which in fact was welcome to the government as the time went by and the increasingly impotent economy desperately needed to be propped by the outcomes of people's half-illegal ventures, starting from allotments where fruit and vegetables were grown and ending with small trade disguised as tourism. Willy-nilly, the regime had to tolerate various forms of entrepreneurship that cropped up and developed outside the system, because they filled the gaps which continued to proliferate in the peaceable system of real socialism... 
Ultimately, society's peaceable dissent prevailed over the regime's omnipotent violence. The government had to resume the peaceable method showed by Solidarity in 1980. The nearly ten-year-long standstill was not a fruitless time as over the period the system of mendacious "peace" slowly but surely effected its own self-destruction.

However, things became far more complicated when ideals and dreams could finally be made a reality. The basic problem which PUWP reformists faced in 1981 consisted in reconciling liberty and freedom of speech and initiative with discipline, without which no joint action could effectively accomplish its aims. In order to bridge the gap between the two quite divergent tendencies, Solidarity applied the method of ongoing discussion. Debating went on not only in the bargaining with the government and its various agencies. First of all, the trade union internally practised what was considered the ideal model of the nation's and the polity's life, i.e. democratic debate in which proposals and solutions were worked out to be enacted by the previously elected representatives of Solidarity's trade-unionist community. The din of discussion and the long hours devoted to often less-than-pleasant quarrelling resulted in joint decisions, while reasonings and votings guaranteed the peaceable method of action. Divisions and conflicts are undoubtedly highly relevant aspects of people's shared life. Ubiquitous debating and discussing where everybody could present their arguments was Solidarity's invention which was supposed to strengthen it and foster coherent action.

This debating - or, to put it in more scholarly terms, deliberative - democracy was a model for and an expected quality of democracy which was envisioned for Poland. We know now that we are rather remote from this model, and the model itself has lost much of its practical relevance, even though it is still remembered and appreciated. The return of Solidarity as an organised trade union meant a decisive shift in relationships between society and the government, leading to the change of the system. The change happened far more quickly than anybody could expect. It was possible because of that profound, practical lesson of discussing, persuading, negotiating, voting and electing that served as a cornerstone of truly peaceable, democratic practices.

But this text was supposed to address social memory and the peaceable method of pursuing, even fighting for, social and civil rights. In the annals of history, Polish Solidarity is inscribed as a peaceable movement of protest and reforms which brought about the collapse of the communist Soviet system. Peaceable negotiations and dissent form a method that will always be symbolically linked to Solidarity. Yet do we, the founders of that social method and the participants in collective actions that we are, remember this and are we proud of it? 
One of the most surprising findings of our research into the memory of the first and inimitable - Solidarity was the view of the peaceable method held by some of the former activists, now members of Solidarity as re-established after 1989. The view was not exceptional; it surfaced across Poland. Specifically, some trade unionists believed that "we were wrong" to abide so consistently by the peaceable methods in the trade-unionist, democratic and independencepursuing movement. Had we been better prepared, some activists in Silesia and Gdansk concluded, and had we not given up so easily, Poland would have been reborn different. For the peaceable method remained the Polish road of transition in 1989. For once, a revolutionary re-building of the state and social life did not take a bloody toll of deaths.

Yet, today, some participants in those seminal events find the lack of victims, fight and confrontation somehow disturbing, if not downright distressing. As if they were disavowing the shift of the 1970s and 80s, when the Polish model of fighting "for noble values" despite the inevitability of failure was discarded. The arduous, demanding and sometimes dispiriting peaceable method, though proven surprisingly effective, is suddenly becoming suspect and not so noble after all. As if the dream of Poland's martyrdom were on the rise again. Perhaps even more surprising is the tendency to consider one's own reasons and standpoints to be absolutely indisputable. Generally, religion, faith and the Church are used to justify their special and unquestionable superiority. Even when discussing matters completely unrelated to the articles of faith, those who proclaim themselves allies of the Church present their positions as irrefutably and uniquely right. In other words, faith and religion are now utilised as a special argument in debate. As a result, the special rights to which some of the participants in debate lay claims practically eliminate any and all discussion. Discussion as practised by and within Solidarity presupposed that everybody was equal and had the same right to speak out. When this principle is violated, discussion as such vanishes.

When the conditions of candid, common discussion vanish, divisions become entrenched and insurmountable; and when these divisions are enhanced by deliberate inequality, peace itself vanishes as well. Peace has won because the work of Solidarity showed that dialogue was possible even between as unequal parties as society organised in Solidarity and the half-totalitarian, omnipotent communist regime. Still, peace seems to be losing its attractiveness and value in free Poland as views held by some of the former activists are elevated into the only right and the only Polish ones.

Their position is justified by a critique of the equality of the successors to the old regime and the continuators of Solidarity's social movement. They seem to contend that if fight had been launched, post-communists would never have been 
able to accede to power again. Critical of Solidarity's peaceable character, the proponents of this view seem to say: if a part of society that always endorsed the communist regime could and does have their political representation, the Polish state is not fully Polish. Worse than that, such a state is even unjust, because it has not put the past on trial. In this perspective, it does not matter that such a trial has in fact (also literally) taken place and is still taking place, even though amidst the building of a new life this trial has not been foregrounded as the most important event. Without a doubt, the views that question Solidarity's strategy of peaceable struggle for social reforms are quite specific. They are apparently linked to grievances about and disappointments with the post-1989 transition period.

Be it as it may, the change is indeed surprising and shows emphatically how fragile the idea of peace with all its important aspects and factors is. Peace is predicated not only on reflection but also on inner discipline, including the discipline of honest memory.

\section{The study Doświadczenie i pamięć Solidarności (Solidarity: Experience and Memory), 2010. Quotations from the interviews:}

1. Solidarity was "An outburst. A gust of freedom."

2. "I experienced something that nobody can take away from me" (Szczecin). "There's a song about the best things that have happened to us in life. I believe it is, it was Solidarity. That's what I'd say. In one sentence" (Lublin).

3. A statement from a group interview in the Tri-City: "I think it would have been better for us if we'd sacrificed 3000 people back in 1989; we'd have peace and quiet now. I was of a different opinion back then, but not anymore today. Today, I don't know. If I were to stand up in a year, in six months, in two years, I surely could" (Gdansk).

4. The respondent interprets Solidarity as an unfulfilled - because bloodless revolution: "For what could the ZOMO do to as after all? They'd have swung their batons a bit, end of story. And if they'd got a good licking, they'd have known they'd got it and would have had to fear the workers, right? [...] When you're born, there's blood. And whatever is paid for in blood is more appreciated. How is Solidarity appreciated? Go out and ask people. It means nothing to most" (Bydgoszcz).

5. The respondent describes how former friends from Solidarity get on with one another (Elbląg):

- Some remained [in Solidarity]... You know, some of us could [be called] liberal or whatever. We joined the Freedom Union [Unia Wolności]. Some of us stayed away [from the current trade union] at all. Others joined the 
Centre Agreement [Porozumienie Centrum], so they're radical. And today it looks like that: when we talk, we don't talk about our, well...

- But you still keep in touch, do you?

- Yes, we do, absolutely. I read Wyborcza, and a friend of mine reads Nasz Dziennik. But when it comes to Solidarity and victimised people, we [...] are always on the same page. But when I start to tell him tings or he to persuade me, then, no, at this moment we go: thick stroke [laughter]. For either I stop seeing you or you stop seeing me.

- Is that what you say at such moments?

- Yes, it is, Thick line. And the unease's over. Because neither will he get me over to his [point of view] nor will I him. [...] No, not really. We've got a few hotheads who, as I told you, would go to the Palace [Presidential Palace in Warsaw]. They would go there. With crosses, and the like things. And some of us have moved on and claim it's the way it should be. That it's good that Poland is free, that it's not in chains [laughter], that it's not anybody's condominium or anything. But others say it is. And they are the same people we worked together with. 



\section{Conclusion: Solidarity and Bad Memory}

It took me several weeks to start writing this book's final chapter, and with every week gone, it was getting more and more difficult. Originally, I planned this chapter as an argumentative essay on how the Solidarity social movement had disappeared from the real lives of Poles but, at the same time, still continued in them. The paradox of this situation was supposed to convey the quintessence of my argument. When I finally got down to writing, another academic year had just started and our socio-political life had acquired a new dynamism, which undermined my earlier conclusions about the legacy of Solidarity. Additionally, the subsequent stage of my field research into the experience and memory of Solidarity only generated very depressing data. Of course, the findings were depressing for me, that is, in terms of a particular socio-political and moral approach, and at the same time they radically differed from social-scientific accounts and interpretations of the vast social movement of the 1980s.

The title of this chapter is ambiguous. First of all, "bad memory" means a "poor memory," or rather a missing memory, that is, not referring to, not recognising and not developing what Solidarity's social and unionist movement produced. Both the post-1989 socio-political practice and the studies carried out in 2010 and 2011 showed a paradoxical situation: the collective memory, which surfaced in everyday life, in the media and in political modes adopted by Poland's democratic politics, hardly ever referenced the "first" Solidarity. Admittedly, in 2015, parliament made $11^{\text {th }}$ August a public holiday of the Solidarity Day, but the fact had long been known only to public servants until the $\mathrm{LaO}$ government sparked a sharp conflict about anniversary celebrations of the accords between the striking workers and the communist regime, which had paved the way for Solidarity. The conflict centred on who and how should organise the anniversary festivities. For years, Jarosław Kaczyński, the leader of the Law and Order, and his aides had tried to deprecate the work of Lech Wałęsa and Wałęsa himself, their manoeuvres triggering a fierce clash among the ex-Solidarity members. Kaczyński is the leader of the $\mathrm{LaO}$, the governing party which has been systematically wrecking Polish democracy - democracy the old reformist movement envisioned and pursued.

The celebrations themselves turned into an aggressive political confrontation. It was hardly a good "public holiday."

The democratic system built in Poland seemed to be deep-seated and wellentrenched. Today, however, it is not so obvious anymore. The system had, and 
still has, features that drastically differ from the model which Solidarity spontaneously developed in the 1980s. The Solidarity model of democracy was fundamentally grounded in citizens' political participation in governance. The "first" Solidarity came up with a participatory democracy model, an essentially direct, deliberative, debating democracy, which was based on an institutionalised form of common and public social debate. What emerged from discussions was supposed to serve as the basis for decision-making and actions launched by the elected representatives. The envisaged ideal of democracy went much further than representative democracy based on the system of political parties, which arose in Poland after 1989.

Admittedly, in many cities and towns the Civic Committees, which were set up after 1989, became embryos of the revived citizenship movement. The local Committees, which represented not only underground Solidarity but also other oppositional Solidarity-affiliated groups and circles, put forward their own candidates for the upcoming election. However, which of the candidates spontaneously proposed by the local Civic Committees ultimately made it to the election tickets was decided in Warsaw. Worse still, those centrally made decisions often contravened the local Committees' express opinions. Regrettably, the democratic principles were indeed violated. This bred bitterness in people, many of whom had made quite serious sacrifices to remain loyal to the Solidarity ideals throughout the hardships and gloom of the 1980s.

Secondly, after the election in June 1989, Solidarity - that is, basically, the NSZZ "Solidarity" - became society's direct political representative as the trade union's members took seats in parliament. At the same time, Solidarity was also a member of the Civic Committees, which made their status unclear. Unsurprisingly, a political fight soon ensued over the position of the Civic Committees as political actors. Their founding idea, which picked up the notion of political participation championed by the Solidarity movement, got inscribed in entirely new realities. In these realities, competition, power struggle and fight for representing the public opinion completely overrode Solidarity and communal political action. A pluralistic party system - a system of democratic representation of interests - started to form at a lightning speed. This triggered a sharp conflict as a result of which the Civic Committees became one of several political actors, and their political life was nipped in the bud. ${ }^{238}$

238 For an insightful discussion of this issue, see Aleksander Hall, Osobista historia III Rzeczypospolitej (Warszawa: Rosner \& Wspólnicy, 2011). 
We can thus posit that the freedom of socio-political action not only spurred a very fast institutional differentiation of social functions and goals, their dispersal and attempts to find distinct forms for their expression, but also produced very clearly delineated ideological orientations and party lines, for which competitive distinction was the need of the moment. Civil society nearly overnight changed into an active public, whose attention had to be stirred in order to win support for the party's performance, for its agenda and its place in the government. The freedom of political action set off a breakneck process in which ideologically diverse actors emerged and a pluralistic political arena was formed to host the competition for power. This is where the earlier communal experience of the Solidarity social movement was questioned and undermined since even diversified social action had previously presumed the precedence of the communal over the competitive.

I believe that this shows the crucial role of the former "party-state"-vs."society" opposition. The fact that the "party-state" was around disciplined the Solidarity movement members and reinforced an authentic sense of "togetherness," in which unity was sustained through the endorsement of the longterm goal of changing the principles of governance. This perspective unified the members over and across any divisions, different concepts and discrepant interests. When freedom was finally won, the power of the hostile regime, which had cemented people together, faded away and social goals became particularised by differently-minded actors. The actors not only wanted to express their distinct goals in a public, equal and communal debate, but also sought to fashion and convey their own social identity in order to garner maximum support. As a result, public debate thoroughly changed, and ventures such as the Porozumienie Ponad Podziałami (Agreement Over Divisions) movement proved entirely unrealistic.

The dark decade of the 1980s had considerably changed Polish society as well. Notably, the reborn Trade Union and the Civic Committees, with Lech Wałęsa and under the banner of Solidarity, won nearly everything they could win in the "contractual" election of 1989 , but only slightly over $60 \%$ of the eligible voters cast their ballot in it. How can this voter absenteeism be explained?

Certainly, it showcased a new mentality and an essential shift in the attitudes of the citizens, which are in fact still widespread in Poland. Sociologists such as Mirosława Marody and Marek Ziółkowski have written about the "privatisation" of attitudes and a retreat from citizenship. They certainly have a point, but I believe that the change involved a more serious development, i.e. a regression to the negative definition of "politics" and consequently of "citizenship." The rise 
of Solidarity as a mass social movement assembling millions of people, ${ }^{239}$ was based on and reinforced a positive definition of civic politics. After the Second World War, the fear of "politics" was instilled in Poles for long years in a variety of manners and fashions. The Solidarity movement as we know it would not have happened if that fear of politics had not been overcome, making people believe that everybody had the right to be a citizen and, as such, to speak out on all matters of interest to individuals, ranging from the simplest, private livelihood issues to the questions of relevance to entire society and the nation. The Solidarity movement was fundamentally based on the recognition of people's universal right to have and articulate their own views and to pursue their own and communal interests. As such, the - emphatically - peaceable Solidarity movement expressed the deepest belief in the sense and importance of debate and discussion as promoting the best individual and collective decisions. People believed that it was possible to negotiate even with the violence-wielding partyand-state authorities. Martial law was a criminal act just because it smothered that civic consciousness, a consciousness erected largely on a vision of citizenship rooted in the Christian, personalist notion of the human as a person and thus as a citizen.

The experience of the 1980s instructed people about the significance of force and violence in politics. It revived the negative definition of politics as action that indispensably involved force and, consequently, some violence. Suddenly regained in 1989, freedom afforded citizens an opportunity not to involve in politics, even if it was "our" politics. Politics could be "sidestepped," for it had lost its moral justification, which had formerly been bound up with opposing the evil represented by the regime. Now, the moral meaning of politics could easily be undercut, or politics could be classified as morally ambivalent and "suspect," all the more easily as the pluralistic party system produced the image of competition rather than of community, thereby side-lining solidarity as manifested in the shared care for all.

Quite positive and even expected in and of itself, the explosion of individualism in Poland had a different tenor than the atmosphere in which the Solidarity movement had formed. While previously civic engagement had been a moral norm inextricable from the idea of the person as a citizen, now these overtones were clearly "private" and heralded a withdrawal from civic involvement. Participation in the Solidarity social movement had considerably elevated

239 Importantly, there was also a peasant Solidarity movement in rural areas, complementing the image of Poles' universal civic engagement. 
the human being as an individual and enhanced the value of personal life. Involvement in debate on general, communal issues had significantly augmented individual lives. Now, the opposite moods prevailed.

The inroads of violence into politics and the notion that force was a weightier attribute of politics than persuasion, reasoning and negotiations affected a considerable part of society and formatively impacted the development of democracy models in post-1989 Poland. Aggression and forcefulness in democratic transactions marked the Polish political arena very early, becoming in fact the fundamental factor in shaping political behaviour models. Today, we reap the poisonous fruit of those early developments as the governing party implements aggressive politics which not only practically questions the rights of the opposition but also consistently seeks to topple democracy as such.

All this started from the slogans which the founder of Solidarity ${ }^{240}$ used in his presidential election campaign in 1990. The catchphrase of "war at the top" profoundly affected the social image of Solidarity. The slogan both underscored the role of force in a brutal political struggle and fractured the sense of community of solidary community - underpinned by the mutual care of all its members for each other.

Re-established after 1989, Solidarity performed a dual function. On the one, hand it served as an "umbrella" of the political and economic reforms, as a result of which in the transition period it was losing social support and approval, especially among the groups whose interests were seriously threatened by the transformations. This concerned a huge proportion of employees in the privatised enterprises and institutions. When Solidarity became a political actor, clearly siding with the right-wing and nationalist factions, the support rates for the trade union slumped even more. Admittedly, Solidarity could and did win new voters, but it was rapidly losing those who had viewed it as a symbol of community before. Previously identified as a unique embodiment of social, national and liberty ideals, Solidarity mutated into just one of the several political actors. This resulted in a degradation of the symbolic Solidarity. It was

240 I have long observed that an utterly competitive and violent vision of politics arose in Poland after 1989. I have recently come across a vivid illustration of the idea that the Polish pattern of political game is quite particular. Talking to the TVN24 [a TV news station; translator's note] after an interview with Zbigniew Brzeziński, Lech Wałęsa said that he saw "democracy as a fight" and even a war, in which all political actors struggle for power and social influence. In fact, Brzeziński had earlier insisted that competition must lead to cooperation, but Wałęsa completely failed to notice that idea ... (TVN24, Fakty po faktach, 8 Nov. 2012). 
only in the celebrations of "late anniversaries" that the Solidarity of the 1980s was evoked otherwise than in terms of the trade union as an actor in the sociopolitical transition.

Obviously, the more the activists of the NSZZ "Solidarity" are drawn into the political power play today, the stronger emphasis they put on the continuity of the trade unionist movement. However, nobody actually believes that this continuity is anything but an illusion. Like many other politicians over the past two decades of the Third Republic, the trade union's activists have recalled Solidarity in order to further their own interests. In practice, this means that interpretations of the Solidarity social movement have disintegrated. What the Solidarity movement was and what goals it pursued has been interpreted differently, depending on the varying immediate political aims. This atomisation has prevented developing and preserving a homogeneous, canonical image of the 1980s movement.

I use the word "disintegrated" deliberately. People who were involved in Solidarity formed their own image of the movement. People who joined Solidarity in 1981 had a highly developed self-awareness of their organisational identity. This awareness was enhanced by the presence of a perfidious enemy, i.e. the party-state with its apparatus of secret services and overt violence, which was ultimately used against Solidarity. But this self-awareness was shaped not only by the sense of threat. Another important formative factor was the novelty of the situation in which new problems had to be solved and, in fact, social inventions had to be continually put on the table and tested while developing the procedures of trade-unionist activities. The least it required was a serious "re-making" of the patterns developed and implemented by the communist state. The organised activity itself provided a strong intellectual stimulus that triggered mental explorations. For thousands, nay millions, of people, participation in the Solidarity movement was an impulse for personal development, for learning a new language and for acquiring new mental and interactive skills. All this could, and did, serve as capital for the future. As it were, the activists of the first, legal period of Solidarity who had stayed in Poland became the core workers in institutions of the democratically transforming polity after 1989.

The individual development and the mental and spiritual growth were stimulated by Solidarity's ongoing debate, in which values and goals were defined and social identities were moulded. Who are we, if we defined ourselves as a peaceable social movement? What are our goals? Which of our goals can be achieved? Solidarity's awareness was not so much an awareness of the movement as rather an awareness in the movement: it was in the process of producing its own identity. The imposition of martial law was a blow to this vigorously developing social self-awareness, in which the conceptual framework instituted for 
social reflection in the People's Republic of Poland was being pulled to pieces. No wonder that the jeopardised communist regime chose to strike back.

Although, the developing critical and constructivist social reflection could not be fully halted, the extraordinary process of communal thinking spawned by the Solidarity movement was frozen indeed. Consequently, the development of self-awareness and the "self-image" of the movement - the representation of the rising social and also national identity - were not symbolically perpetuated. Admittedly, the findings of empirical research on Solidarity carried out at the time (Touraine's research and my own studies on the establishment of Solidarity) could be regarded as an at least partial image of this living self-awareness. In Poland, Touraine's study was particularly relevant insofar that the participants in the project later became activists of underground Solidarity. In keeping with Touraine's specific research method, they had acquired skills of organising activity even in highly adverse circumstances. They put to good use what they had learned when participating in the study.

Strikingly, there are very few Polish sociological studies on the Solidarity movement. No wonder that Solidarity researchers have been too feeble an actor to seriously put their image of the trade union and the movement into play. Additionally, as citizens, the researchers were also involved in the transition process and as such stood no chance to come up with a discursive, study- and argumentation-based image of Solidarity, an image disentangled from all current biases.

We can thus wonder whether the civic awakening caused by the Solidarity movement indeed bore no fruit in the transition, when a new social and political order was being forged. It is not easy to answer that. After 1989, sociologists have tended to report a decline of citizenship attitudes and social engagement. The image of a pro-active society in the conditions of repression of the 1980s differs sharply from the image reported after $1989 .{ }^{241}$ It may all be slightly exaggerated. If we re-assess the situation by focusing on the social protests, demonstrations and other public activities of the 1990s, in all of which the people involved put forward a range of demands, our appraisal of the period may be different. Two American social scholars of Polish descent, Jan Kubik and Grzegorz Ekiert, have made every effort to show that Poles were not passive and meek "objects"

241 For an excellent analysis of social and civic activities in the dark decade of the 1980s, see Inka Słodkowska, Społeczeństwo obywatelskie na tle historycznego przełomu: Polska 1980-1989 (Warszawa: Instytut Studiów Politycznych PAN, 2006). 
worked upon by the reformist elites after $1989 .{ }^{242}$ For one, the organised movement of social protest in Poland was incomparably stronger than in the other transforming real-socialist countries. Besides, it expressed social demands which insisted on taking various social interests into account. Since no forum for any direct and common public debate was created, civic participation found its outlet in mass protests. Seething with social demands, the protest movement was undoubtedly a manifestation of unfulfilled expectations. As time went by, it faded away because people had adjusted to the levelling-out political system, a system of pluralist, party-based representation.

An interesting and partly realised aspiration pursued by the Solidarity trade unionists of the 1980s which certainly deserves mentioning was the idea of socialising enterprises. Such socialisation meant that the employees were to take over proprietary control of their workplaces. During Touraine's research, our activists had come up with such a notion and, in fact, addressed it in conjunction with the market principles. Owned by their employees, the enterprises were supposed to be rational economic stakeholders on the market. The first step towards making this idea a reality was taken when General Jaruzelski's cabinet adopted a law on employees' self-management. The employees' representatives and the managements formed an executive body of an enterprise. I believe that the fact that many workers had been part of such employees' self-management boards significantly contributed to the later transition, as it offered experience which helped people grasp the rules of management and economic rationality. This had an important role in the transformation processes. Subsequently, revived in 1989, the NSZZ "Solidarity" succeeded in implementing a special privatisation model against the objections raised by Leszek Balcerowicz, Deputy Prime Minister who launched the neoliberal economic reform programme. The model had it that employees, boards and managements became owners of the privatised enterprises. The model was dubbed the "employee-owned company path" or, in bureaucratic parlance, the "leasing path." The enterprises were given a rather short period to restructure, become competitive on the market and achieve profits. After this period (of, as a rule, five years), they were turned into companies with employees becoming

242 Grzegorz Ekiert and Jan Kubik, Rebellious Civil Society: Popular Protest and Democratic Consolidation in Poland, 1989-1993 (Ann Arbor: University of Michigan Press, 1999); see also Grzegorz Ekiert and Jan Kubik, "Protesty społeczne w nowych demokracjach: Polska, Słowacja, Węgry i Niemcy Wschodnie (1989-1994), Studia Socjologiczne 4(147), 1997. 
shareholders in their enterprises. When a few years ago I collaborated with Professor Andrzej Kojder on a research project studying these enterprises, we found that the workplaces turned into "employee-owned companies" were among the most effective privatised enterprises.

Moreover, with such a privatisation model, the costs borne by the employees were lowest. However, rather importantly, an overwhelming majority of the employees sold their shares and, as such, gave up on the possibility to co-own their enterprises. If this privatisation model had been the major mechanism of the economic transition, the social cost of the transition would certainly have been much lower. At the same time, it turned out that ideal of engagement through company co-ownership was not socially attractive. Only a negligible fraction of the employees decided to keep their shares. Consequently, even this ideal inherited from the "first" Solidarity proved insignificant in motivating people's behaviours in the new order.

Essentially, the vast social movement of Solidarity was without a doubt a critical factor in the collapse of Soviet communism and certainly served as the real and symbolic origin of the post-1989 independent and democratic Poland. Despite that, it can be doubted that the experience of the "first" Solidarity became a broadly accepted foundational myth of the Third Republic of Poland. If it had been so, at least the most important values preached and practised by the Solidarity movement would have become the symbolic lynchpin of the new socio-political order. This, however, is debatable especially if we survey the developmental trajectory of the NSZZ "Solidarity" as a socio-political actor after 1989. Similar doubts arise when examining the input of the trade-union leaders into the dismantling of the democratic order we have been witnessing of late. The currently endorsed values are the polar opposites of the values championed in 1981 and, later, into the 1980s.

When we study the NSZZ "Solidarity" activists today, we find an organisation which is above all a political actor with clearly defined ideological leanings, which have little in common with the movement of the 1980s. This shift is symbolically expressed in the Law and Order's famous slogan that surprisingly cleaves Solidarity's fundamental message by pitting "solidary Poland" against "liberal Poland." The point is that "liberal Poland," as it were, stands for what the movement members cherished in the 1980s, i.e. for democracy, which enables citizens to undertake individual actions in accordance with their views and interests, protects human rights and safeguards personal rights. The current Trade Union Solidarity's leadership and activists side with one party - the $\mathrm{LaO}$ and subscribe to its slogan, which fractures the past. The political competition has ultimately abolished the possibility to derive shared models from the past. 
Solidarity with its ideological message has lost the power to generate patterns of conduct and action appealing to all Poles.

And yet, paradoxically, the experience of the past is extraordinarily - astonishingly even - vibrant. In many local communities, especially in 2010 and 2011, we found groups of friends dating back to the old Solidarity who met up on a regular basis, albeit not very often. They treated these meetings as a ritual of sorts, which spoke to the significance they all attributed to the experience of that "first" Solidarity. However, the latest field research of 2012 found that those Solidarity-based friendly bonds had been broken nearly everywhere. In many towns, it proved virtually impossible to bring together people who had once played important roles in the Solidarity movement. As the political conflict exacerbated last year, the meetings serving to revive the memory of the old community were impossible to continue.

In spite of that, further studies have provided evidence of robust memories of what a stupendous experience the involvement in the Solidarity movement had been. They are certainly lyrical memories. Whatever more or less dramatically tinted reprisals the respondents faced during martial law for their earlier engagement, almost all of them regard the time of the establishment and legal activity of the NSZZ "Solidarity" as one of their most important and constructive experiences in life. They speak of it as living their lives to the full and enjoying the rewarding sense of social community. The lyrical overtone of these memories is an effect of this fundamental experience of communality in everyday public and private life. Such feelings from 1980-1981 were often extended onto the aftermath of martial law and expressed in people's readiness to help others, especially those who suffered harsher harassments.

It could seem that such memories, emotionally laden and coming alive in vivid colours in sociological interviews, still carry a significant social and cultural potential. However, expressive of the current conflicts, the swiftly aggravating contrast between the edifying memories and the scathing, hostile evaluation of people who now think differently questions the potential of that lyrical remembrance. There is good reason to conclude that the individuals who are so deeply attached to the good inscribed in their memories hardly build on this good in their everyday lives. The implication of this insight is sad indeed: the most beautiful event in the lives of Poles only exists as a memory now... This memory, heartening though it may be, has hardly any bearing on our life today. 


\section{Bibliographic Note}

Most of the texts included in this volume have been published elsewhere. They have all been revised for this edition. Part One of this book appeared first in one hundred mimeographed copies beyond the reach of censorship (I. Krzemiński, G. Bakuniak, H. Banaszak and A. Kruczkowska, Polacy - jesień '80. Proces tworzenia niezależnych organizacji zwiąkowych; Warszawa: Uniwersytet Warszawski, 1983) and then as a samizdat printed book (I. Krzemiński, Solidarność 1980. Proces powstawania organizacji zwiazkowych "Solidarności"; Warszawa: Wydawnictwo Niezależne WOLA, 1989). Subsequently, it was released by Oficyna Naukowa as the first part of the book entitled Solidarność. Projekt polskiej demokracji in 1997. The second part which was added to that book contained papers which had earlier been published mainly by the underground Wydawnictwo Niezależne Wola (Świat zakorzeniony; Warszawa, 1988). In 2005, a new edition of Polacy - jesień '80. Proces tworzenia niezależnych organizacji zwiazkowych appeared as the third volume in the Socjologia Niezapomniana series, published by the Faculty of Philosophy and Sociology, University of Warsaw (Warszawa, 2005).

Most of the papers included in Part Three of this volume have appeared in print before as well:

"Solidarność - organizacja polskich nadziei” (“Solidarity: The Organisation of Polish Hopes") in Solidarność. Wydarzenie, konsekwencje, pamięć, ed. Antoni Sułek (Warszawa: Wydawnictwo IFiS PAN, 2006).

"Rewolucja, Solidarność, słowo" ("Revolution, Solidarity and Words") in Retoryka i polityka. Dwudziestolecie polskiej transformacji, eds. M. Czyżewski, S. Kowalski and T. Tabaka (Warszawa: Wydawnictwa Akademickie i Profesjonalne, 2010).

"W szponach złej polityki” ("In the Grip of Pernicious Politics") in Znak no. 565, 2002.

"Republika zawistników” (“The Republic of Hateful Enviers") in Przeglad Polityczny no. 78, 2006.

"Pokój jako metoda społecznego działania" ("Peace as a Method of Social Action”) in Pokój (Gdańsk: Gdański Areopag, 2012). 



\section{Index of Names}

A

Adamowicz, Paweł 285

Arendt, Hannah 211

B

Bakuniak, Grzegorz 31, 145, 151, $169,170,180,243,345$

Balcerowicz, Leszek 277, 342

Banaszak, Henryk 31, 243, 345

Bellah, Robert 314

Bernhard, Michael H. 21, 22, 25, 225, 243, 246

Błaszkiewicz, Anna 243, 244

Borusewicz, Bogdan 227, 229

Bratkowski, Stefan 98

Brzezinecki, Andrzej 226

Brzeziński, Zbigniew 339

Brzostek, Jerzy 64

Bujak, Zbigniew 48, 251

C

Chamfort, Sébastien-Roch

Nicolas de 88

Chmiel, Beata 231, 243

Ciechorska-Kulesza, Karolina 296

Czyżewski, Marek 268, 345

D

Diana, Princess of Wales 310

Dobrowolski, Stanisław Ryszard 90

Doktór, Tadeusz 170

Doroszewski, Witold 18

Dubet, François 142, 152, 165

Durkheim, Émile 36, 155, 317

Dziwisz, Stanisław 310

E

Ekiert, Grzegorz 15, 240, 241, 259, 341,342
F

Fedorowicz, Jacek 98

Fromm, Erich 191-195, 279

G

Garewicz, Jan 157, 158

Gierek, Edward 26, 61, 84, 90, 114, $145,146,224,225,227,256,257$, $267,279,321,325$

Giertych, Roman 312

Goldfarb, Jeffrey C. 243, 246

Gomułka, Władysław 321

Goodwyn, Lawrence 24-26

Grabowska, Mirosława 254, 260, $265,268,272$

Gross, Jan Tomasz 175, 197, $197-$ 199, 256, 273

Gwiazda, Andrzej 297-300

H

Hall, Aleksander 336

Himilsbach, Jan 98

I

Iwaszkiewicz, Jarosław 98

J

Jakubowska, Iwona 31

Jaruzelski, Wojciech 91,178, 182,

$230,258,261,300,329,342$

Jedlicki, Jerzy 227

John Paul II (Karol Wojtyła) 92, $145,174,176,183,224,226,228$,

247, 251, 298, 310, 321

Jóźko, Marcin 15

Jung, Carl Gustav 215

K

Kaczyńska, Elżbieta 231, 243 
Kaczyński, Jarosław 272, 274, 277, 303, 305, 335

Kaczyński, Lech 272, 303, 305-313, 318

Kaim, Franciszek 79

Karkoszka, Alojzy 84, 85

Karos, Zdzisław 173

Karpiński, Wojciech 149

Kociołek, Stanisław 111

Kojder, Andrzej 343

Komorowski, Bronisław 303

Kopeć, Aleksander 84

Koralewicz, Jadwiga 281

Koseła, Krzysztof 170, 264

Kowalczyk 91

Kowalski, Sergiusz 268, 345

Krasnodębski, Zdzisław 269

Król, Marcin 17, 182

Kruczkowska, Anna 31, 345

Krzemiński, Ireneusz 31, 136, 145, 150, 151, 153, 169, 184, 186, 221, $231,235,243,246,249,254,260$, $268,278,279,285,293,324,345$

Kubik, Jan 15, 22, 25, 240, 241, 243, 246, 259, 341, 342

Kuczyński, Paweł 24, 142

Kurczewski, Jacek 257

Kuroń, Jacek 225

L

Laba, Roman 24-26

Lachowicz-Tabaczek, Kinga 319

Legutko, Ryszard 269

Lenin, Vladimir (Vladimir Ilyich

Ulyanov) 24, 26, 96, 227

Lepper, Andrzej 273

M

Mach, Bogdan W. 280, 281

Makowski, Jarosław 226

Malewski, Andrzej 35
Marody, Mirosława 41, 157, 165167, 198, 199, 241, 337

Martyniak, Krzysztof 15

Marx, Karl Heinrich 24, 25, 96, 119, 180, 183, 315

Mazowiecki, Tadeusz 15, 219, 253, 301

Mead, George Herbert 37, 38, 42, 244

Merton, Robert K. 155

Michnik, Adam 225

Mikułowski-Pomorski, Jerzy 156

Miłosz, Czesław 97, 98, 246

Modzelewski, Karol 49

Mokrzycki, Edmund 142

Montesquieu, Charles Louis de 144

Morris, Charles W. 38

$\mathbf{N}$

Narożniak, Jan 110

Nesterowicz-Wyborska, Justyna

Nowak, Krzysztof 145, 169, 170, 180, 244

Nowak, Stefan 31, 136, 145, 154, $155,159,169,235,260$

O

Obirek, Stanisław 226

Offe, Claus 309

Ogrodnik, Wojciech 15, 220

Ortega y Gasset, José 194, 207, 258

Ossowska, Maria 156, 157

Ossowski, Stanisław 197

Ost, David 20, 225, 226, 243

$\mathbf{P}$

Pachnowska, Beata 319

Pańków, Włodzimierz 180

Picasso, Pablo (Pablo Ruiz Blasco) 321

Pietrzak, Jan 98 
Piłsudski, Józef 294, 310

Piotrowski, Andrzej 268

Podgórecki, Adam 165

Poleszczuk, Jan 31

Popiełuszko, Jerzy 166, 174, 176179, 181, 183

Putin, Vladimir 305

Putrament, Jerzy 98

Puzynina, Jadwiga 268

Pyjas, Stanisław 159, 160

R

Rakowski, Mieczysław Franciszek 182, 310, 317, 318

Reagan, Ronald 183

Riesman, David 206

Rogulska, Beata 324

Rojek, Paweł 345

Rokeach, Milton 280

Rokita, Jan Maria 272

Rostworowski, Marek 136

Rousseau, Jean-Jacques 144

Rydzyk, Tadeusz 271, 274, 312

Rymkiewicz, Jarosław Marek 175

$S$

Scheler, Max 148, 202, 212

Siciński, Andrzej. 157

Simmel, Georg 197

Skorupka, Stanisław 18

Słodkowska, Inka 220, 341

Speier, Hans 35

Staniszkis, Jadwiga 241, 270, 271

Strauss, Anselm 37

Strzelecki, Jan 14, 142, 152, 165, 203, 293

Strzeszewski, Michał 326

Sułek, Antoni 31, 136, 244, 246, 264, 317,345
Szawiel, Tadeusz 155, 156, 254, 265

Szczesiak, Edmund 227

Śniadek, Janusz 299

Śpiewak, Paweł 153, 249, 254, 265, 273

Świderski, Bronisław 13

$\mathrm{T}$

Talleyrand-Périgord, Charles

Maurice de 258

Terlikowski, Tomasz Piotr 271

Tischner, Józef 18, 169, 272

Tobis, Tomasz 290-292, 298

Tocqueville, Alexis de 148, 149, 152, 198, 205-207, 232, 233, 235

Touraine, Alain 23-25, 28, 142, 143, $152,165,223,233,234,246,292$, $293,341,342$

Tymowski, Andrzej 25

U

Urban, Jerzy 91, 172, 183, 257

W

Walentynowicz, Anna 298-300

Wałęsa, Lech 24-26, 82, 113, 175, 219, 230, 253, 297-301, 335, 337,339

Wasilewski, Dominik 15

Weber, Max 213, 233

Weil, Simone Adolphine 144, 146, 160-162

Wieviorka, Michel 28, 142, 152, 165

Wyka, Anna 244

Wyszyński, Stefan 80

Z

Ziółkowski, Marek 337

Zybertowicz, Andrzej Janusz 271 

Studies in Political Transition

Edited by Klaus Bachmann

Vol. 1 Klaus Bachmann: Vergeltung, Strafe Amnestie. Eine vergleichende Studie zu Kollaboration und ihrer Aufarbeitung in Belgien, Polen und den Niederlanden. 2011.

Vol. 2 Klaus Bachmann / Thomas Sparrow-Botero / Peter Lambertz: When Justice Meets Politics. Independence and Autonomy of $A d$ Hoc International Criminal Tribunals. 2013.

Vol. 3 Kim Christiaens / Idesbald Goddeeris / Magaly Rodríguez García (eds.): European Solidarity with Chile 1970s-1980s. 2014.

Vol. 4 Klaus Bachmann / Igor Lyubashenko (eds.): The Maidan Uprising, Separatism and Foreign Intervention. Ukraine's complex transition. 2014.

Vol. 5 Klaus Bachmann / Dorota Heidrich (eds.): The Legacy of Crimes and Crises. Transitional Justice, Domestic Change and the Role of the International Community. 2016.

Vol. 6 Klaus Bachmann: Der Bruch. Ursachen und Konsequenzen des Umsturzes der Verfassungsordnung Polens 2015-2016. 2016.

Vol. 7 Igor Lyubashenko: Transitional Justice in Post-Euromaidan Ukraine. Swimming Upstream. 2017.

Vol. 8 Krystyna Szafraniec / Jarosław Domalewski / Krzysztof Wasielewski / Paweł Szymborski / Marcin Wernerowicz. The Me-Generation in a Post-Collectivist Space. Dilemmas in a Time of Transition. 2018.

Vol. 9 Klaus Bachmann / Gerhard Kemp / Irena Ristić (eds.): International Criminal Tribunals as Actors of Domestic Change. The Impact on Institutional Reform Vol 1. 2019.

Vol. 10 Klaus Bachmann / Gerhard Kemp / Irena Ristić (eds.): International Criminal Tribunals as Actors of Domestic Change. The Impact on Institutional Reform Vol 2. 2019.

Vol. 11 Klaus Bachmann / Irena Ristić / Gerhard Kemp (eds): International Criminal Tribunals as Actors of Domestic Change. The Impact on Media Coverage. Volume 1. 2019.

Vol. 12 Klaus Bachmann / Irena Ristić / Gerhard Kemp (eds): International Criminal Tribunals as Actors of Domestic Change. The Impact on Media Coverage. Volume 2. 2019.

Vol. 13 Ireneusz Krzemiński: Solidarity: The Unfulfilled Project of Polish Democracy. 2019.

www.peterlang.com 
